\title{
O DIREITO INTERTEMPORAL E OS LIMITES DA PROTEÇÃO DO DIREITO ADQUIRIDO
}

\author{
Dissertação de Mestrado \\ Orientadora: Professora Doutora Daisy Gogliano
}

Faculdade de Direito da Universidade de São Paulo

São Paulo

2009 


\title{
FILIPE ANTÔNIO MARCHI LEVADA
}

\section{O DIREITO INTERTEMPORAL E OS LIMITES DA PROTEÇÃO DO DIREITO ADQUIRIDO}

\author{
Dissertação apresentada para Banca Examinadora da Faculdade \\ de Direito da Universidade de São Paulo como exigência parcial \\ à obtenção do título de Mestre em Direito Civil, sob orientação \\ da Professora Doutora Daisy Gogliano
}

Faculdade de Direito da Universidade de São Paulo São Paulo 
BANCA EXAMINADORA 
"Se o tempo fosse apenas ouro, Talvez pudesses perdê-lo. - Mas o tempo é vida, E tu não sabes quanta te resta." (São Josemaria Escrivá) 
Dedico este trabalho a meus irmãos Liliana, Fábio, Tatiana e Nicolas, alegria, amizade, amor e esperança. 


\section{Agradecimentos}

Pessoas sem as quais nada disto teria sentido: Cláudio Antônio Soares Levada e Ana Lúcia Eber Marchi, meus pais, meus heróis; Liliana Maria Marchi Levada, Fábio Henrique Marchi Levada, Tatiana Maria Marchi Levada e Nicolas Antônio Andreaça Levada, irmãos queridos e companheiros; Ana Paula Guarisi Mendes, meu amor.

Pessoas sem as quais nada disto teria sido possível: Professora Dra. Daisy Gogliano, minha orientadora, exemplo de dedicação acadêmica; Professor Dr. Nestor Duarte, um ícone, um guia; Professora Dra. Giselda Maria Fernandes Novaes Hironaka, grande incentivadora; Professor Dr. Cláudio Antônio Soares Levada, sempre pronto a debater; Professor Dr. José Maria Arruda de Andrade, que me despertou a idéia do mestrado; Pinheiro Neto Advogados, onde tive o privilégio de advogar, e Dr. Werner Grau Neto, os quais me concederam licença para elaboração da dissertação.

Pessoas que contribuíram para a elaboração deste trabalho: Professora Dra. Rosa Maria de Andrade Nery, que nos disponibilizou sua magnífica biblioteca; Dr. Pedro Rebello Bortolini, Dr. Alexandre Outeda Jorge e Dra. Ana Paula Guarisi Mendes, que realizaram a revisão final do texto; D. Wilma dos Santos Mendes, que nos auxiliou com o francês.

Agradeço ainda ao Professor Dr. Nestor Duarte, à Professora Dra. Rosa Maria de Andrade Nery, à Professora Maria Cristina Zucchi e ao douto advogado Dr. Celso Cintra Mori pelas gentis cartas de recomendação para o processo seletivo.

Por fim, os Professores Dr. José Luiz Gavião de Almeida e Dr. José Fernando Simão, que tiveram a atenção e o cuidado de nos avaliar no exame de qualificação.

A todos, meu carinho e gratidão. 


\section{RESUMO}

O Brasil possui um sistema peculiar de direito intertemporal, segundo o qual (1) em regra, a lei nova atua com efeito imediato, atingindo os fatos presentes, futuros e pendentes; todavia (2) pode o Legislador conferir efeito retroativo à lei nova, dispondo que os efeitos desta atinjam fatos passados; (3) seja qual for o efeito da lei nova, o Juiz deverá garantir que esta não atinja o direito adquirido, o ato jurídico perfeito e a coisa julgada, conferindo ultratividade aos efeitos da lei revogada. Diferentemente do que se dá com sistemas estrangeiros, no Brasil o princípio da irretroatividade limita todos os possíveis efeitos da lei nova, e não somente o retroativo. Nesse contexto, para resolver os problemas de direito intertemporal, o intérprete deverá se valer da seguinte regra: "independentemente de seu particular efeito, aplica-se a lei nova desde que não ofenda o direito adquirido, o ato jurídico perfeito e a coisa julgada". Para verificar se existe uma destas três figuras, deverá analisar se o direito integra o patrimônio do titular (direito adquirido), se o fato já produziu todos os seus efeitos (ato jurídico perfeito) ou se a decisão de mérito não comporta mais recursos (coisa julgada). Auxiliam nesta tarefa, por interpretação contrario sensu, as noções de expectativa de direito e de faculdade jurídica. Este sistema resolve a generalidade das questões de direito intertemporal, não devendo o intérprete importar regras alienígenas que destoam da tradição jurídica nacional, e.g. a teoria dos fatos consumados e dos níveis de retroatividade. A demonstrar esta tese, resolvemos os principais conflitos de leis no direito civil, confrontando o Código Civil de 2002 com o de 1916. A todo momento, porém, procuramos analisar o sistema jurídico como um todo, verificando se a lei nova realmente contraria direito adquirido ou se este já não poderia ser considerado um não-direito mesmo não havendo lei que o proibisse. $\mathrm{O}$ intérprete não pode permitir que o direito intertemporal seja utilizado para agasalhar atos imperfeitos e direitos aparentes, blindando negócios inválidos que não têm e não devem receber proteção contra o advento de lei nova que os expressamente proíba.

Palavras-chave: Intertemporal. Irretroatividade. Adquirido. Retroatividade. Civil. 


\section{RIASSUNTO}

Il Brasile possiede un sistema peculiare di diritto intertemporale, secondo il quale (1) in genere, la legge nuova agisce con effetto immediato, raggiungendo i fattori presenti, futuri e pendenti; tuttavia (2) il Legislatore può conferire effetto retroattivo alla legge nuova, disponendo che gli effetti di questa raggiungano i fatti passati; (3) qualsiasi sia l'effetto della legge nuova, il Giudice dovrà garantire che questa non raggiunga il diritto acquisito, l'atto giuridico perfetto e la cosa giudicata, conferendo ultrattività agli effetti della legge revocata. Diversamente da quello che succede ai sistemi stranieri, in Brasile il principio della irretroattività limita tutti i possibili effetti della legge nuova, e non solo il retroattivo. In questo contesto, per risolvere i problemi di diritto intertemporale, l'interprete dovrà avvalersi della seguente regola: "indipendentemente dal suo particolare effetto, si applica la legge nuova a condizione che non offenda il diritto acquisito, l'atto giuridico perfetto e la cosa giudicata”. Per verificare se esista una di queste tre figure, dovrà analizzare se il diritto integra il patrimonio del titolare (diritto acquisito), se il fatto ha già prodotto tutti $i$ suoi effetti (atto giuridico perfetto) o se la decisione del merito non comporta più ricorsi (cosa giudicata). A questo compito aiutano, per interpretazione "contrario sensu”, le nozioni di aspettativa di diritto e di facoltà giuridica. Questo sistema risolve la generalità delle questioni del diritto intertemporale, non dovendo l'interprete importare regole estranee che escano dalla tradizione giuridica nazionale, 'e. g.' la teoria dei fatti consumati e dei livelli di retroattività. A dimostrare questa tesi, abbiamo risolto i principali conflitti di leggi nel diritto civile, confrontando il Codice Civile del 2002 con quello del 1916. In tutti $i$ momenti, però abbiamo cercato di analizzare il sistema giuridico come un tutto, verificando se la legge nuova realmente va contro il diritto acquisito o se questo già non potrebbe esser considerato un "non-diritto" anche qualora non ci siano leggi che lo proibiscano. L'inteprete non può permettere che il diritto intertemporale sia utilizzato per abbracciare "atti imperfetti" $e$ "diritti apparenti", bloccando negozi invalidi che non hanno e non devono ricevere protezione contro l'apparire di legge nuova che li proibisca espressamente.

Parole chiave: Intertemporale. Irretroattività. Acquisito. Retroattività. Civile 


\begin{abstract}
Brazil adopts a particular intertemporal law system, namely: (1) as a rule, the new law has immediate effects, reaching present, future and ongoing events; however (2) such system allows the lawmaker to confer retroactive effects on the new law so that its effects may reach past events; (3) whatever the effects of the new law, the judge must ensure that it has no negative impact on vested rights, juristic acts, and "res judicata", thus protecting the effects of the supervened law. Unlike what happens in foreign systems, the principle of non-retroactivity in Brazil puts a limit on all potential effects of the new law, not only on its retroactive effects. Accordingly, to solve intertemporal law problems, the law interpreter must abide by the following rule: "whatever the effects specifically ensuing from it, a new law shall apply to the extent that it does not violate vested rights, juristic acts and 'res judicata'”. To pass this three-tiered test, he must check whether the potentially affected right has been definitely acquired by its holder (vested right); whether the fact has produced all effects expected from it (juristic act); or whether a decision on the merits is final and conclusive ("res judicata"). The ideas of expectant right and legal prerogatives may assist in this task, by contrary interpretation. This system suffices to solve the intertemporal law issues in general, and the interpreter should not consider foreign rules that find no backing in Brazilian legal tradition, such as the theory of fait accompli and retroactivity levels. In support of this stance, this work will solve the major conflicting civil law issues, by contrasting the 2002 Civil Code to its 1916 counterpart. Nevertheless, this work will look into the legal system as a whole, probing whether the new law does run counter vested rights or whether the latter should not be viewed as a "non-right" even when there is no law prohibiting them. The interpreter cannot allow intertemporal law to be used as a shelter for "non-juristic acts" and "apparent rights", thus protecting invalid acts that are not (and should not be) accorded protection against the advent of the new law expressing proscribing them.
\end{abstract}

Key Words: Intertemporal. Non-retroactivity. Vested. Retroactivity. Civil. 


\section{SUMÁRIO}

\section{PRIMEIRA PARTE. QUESTÕES INTRODUTÓRIAS}

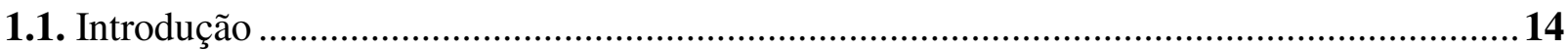

1.2. As duas teorias que mais influenciaram o direito intertemporal brasileiro ........................17

1.2.1. A doutrina de Carlos Francesco Gabba - a teoria da proteção do direito

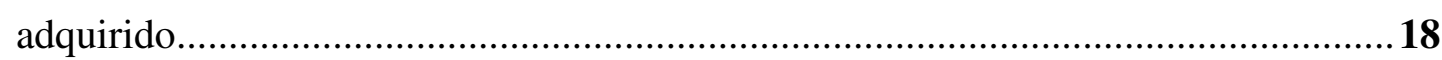

1.2.2. A doutrina de Paul Roubier - a teoria das situações jurídicas..................................19

1.3. A doutrina brasileira de Rubens Limongi França - o resgate histórico da tradição

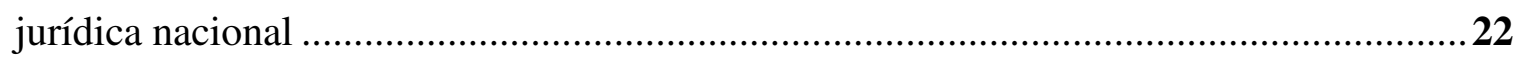

1.4. O estado atual da matéria no Direito estrangeiro ...............................................................31

1.4.1. A Espanha e a teoria dos "níveis de retroatividade"...............................................31

1.4.2. A Itália e a teoria dos "fatos consumados" .................................................................36

1.4.3. A França e o efeito imediato mitigado .....................................................................38

\section{SEGUNDA PARTE. PRINCÍPIOS E REGRAS DO DIREITO INTERTEMPORAL}

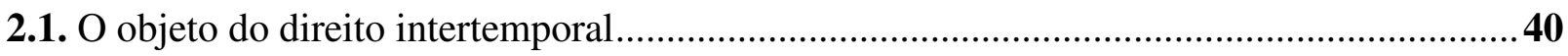

2.2. Os fatos passados, presentes, futuros e pendentes ..........................................................41

2.3. Os possíveis efeitos da lei - considerações gerais ...........................................................42

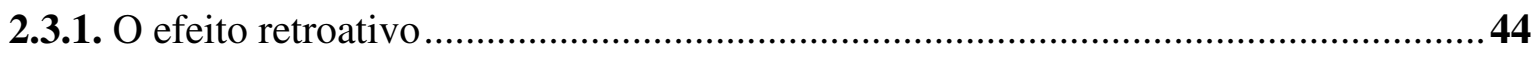

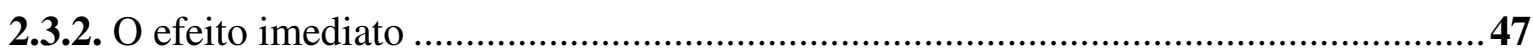

2.3.3. A ultratividade dos efeitos da lei revogada............................................................50

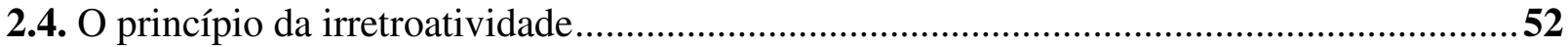

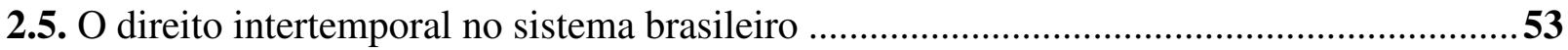

2.5.1. O direito intertemporal nas Constituições Federais de 1824, 1891, 1934, 1937,

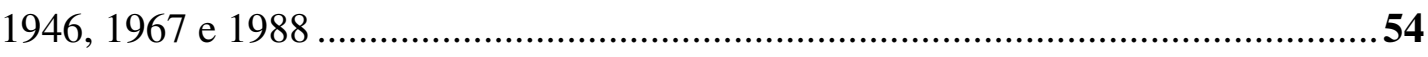

2.5.2. O direito intertemporal nas Leis de Introdução ao Código Civil de 1916, 1942 e

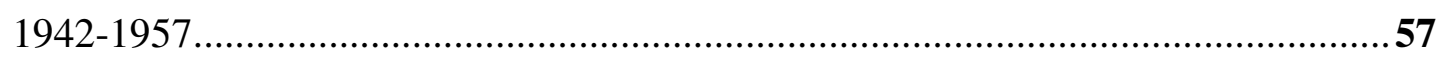

2.5.3. Os projetos para alteração da Lei de Introdução ao Código Civil ..............................58

2.6. A quem vinculam as regras do efeito imediato e da proteção ao direito adquirido critérios e limites para a retroatividade expressa 


\section{TERCEIRA PARTE. DIREITO ADQUIRIDO E FIGURAS RELACIONADAS}

3.1. A natureza infraconstitucional do conceito de direito adquirido .......................................63

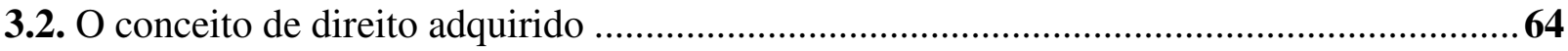

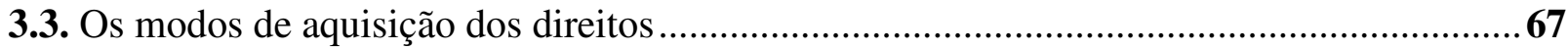

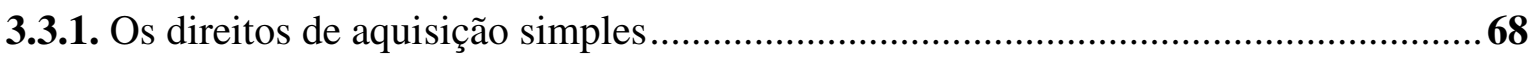

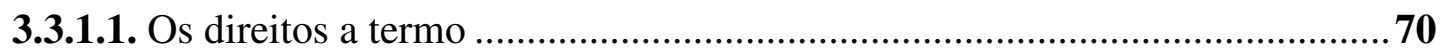

3.3.1.2. Os direitos sob condição suspensiva …...................................................71

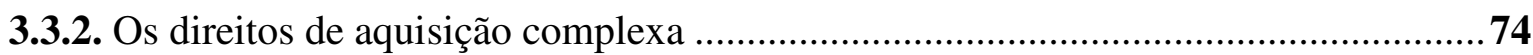

3.3.2.1. Os direitos de aquisição por elementos autônomos ......................................76

3.3.2.2. Os direitos de aquisição por elementos dependentes ...................................77

3.3.3. O direito adquirido proporcional - a questão da alteração do prazo para aquisição

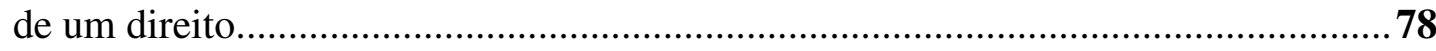

3.4. Figuras que se assemelham e possuem a mesma proteção conferida ao direito

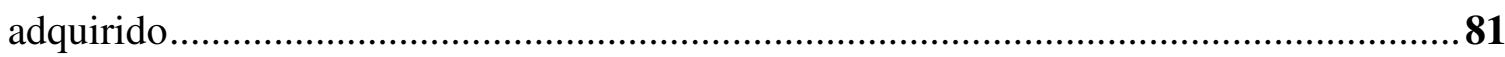

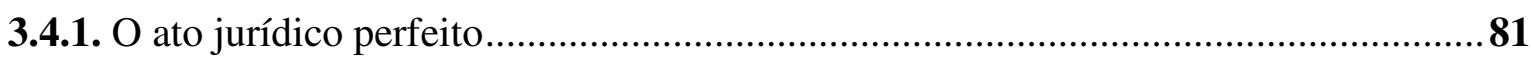

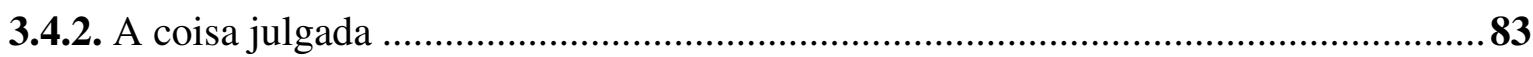

3.5. Figuras que se assemelham mas não possuem a mesma proteção conferida ao direito

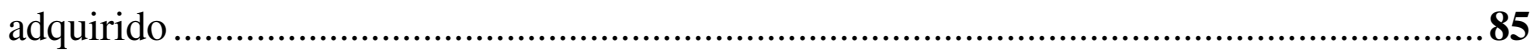

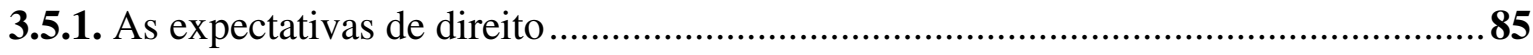

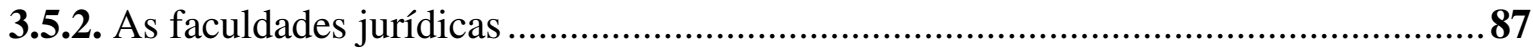

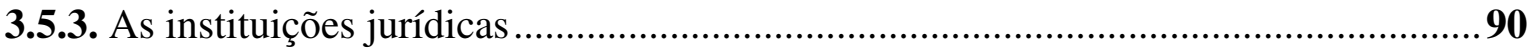

\section{QUARTA PARTE. OS LIMITES DA PROTEÇÃO DO DIREITO ADQUIRIDO}

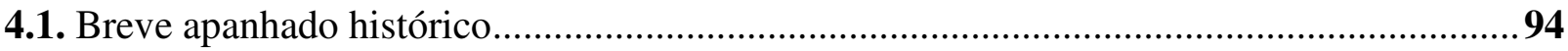

4.2. Critérios para o estabelecimento de limites à proteção do direito adquirido........................97

4.2.1. O critério da ordem pública - crítica ...................................................................97

4.2.2. Os critérios nascidos no julgamento do $R E n^{\circ} 141.190-2$ : teoria da imprevisão e ponderação de princípios - crítica.........................................................................105

4.2.3. O paralelo com as teorias processuais de relativização da coisa julgada ..................113

4.2.4. O critério que propomos - a ponderação na origem .................................................117 


\section{QUINTA PARTE. O DIREITO INTERTEMPORAL APLICADO - AS PRINCIPAIS CONTROVÉRSIAS NO DIREITO CIVIL}

5.1. Parte Geral

5.1.1. A alteração da capacidade civil, aos dezoito anos - o artigo $5^{\circ}$, caput, do Código Civil de 2002

5.1.2. Aplicação "retroativa" dos novos vícios, estado de perigo e lesão - os artigos 156 e 157 do Código Civil de 2002.

5.1.3. A alteração de prazos prescricionais, em geral.

5.1.4. Os prazos reduzidos pelo Código Civil de 2002 - o artigo 2.028

5.1.5. A necessidade de duas testemunhas para se conferir qualidade de título executivo ao instrumento particular - artigo 221 do Código Civil de 2002 artigo 585, inciso II, do Código de Processo Civil

5.2. Direito das Obrigações

5.2.1. O percentual dos juros de mora legais no Código Civil de 2002 - SELIC x CTN ... 138

5.2.2. O novo limite para os juros convencionados - Código Civil de 2002 e Lei da Usura

5.2.3. A contagem dos juros de mora no Código Civil de 2002 - as inovações constantes dos artigos 398 e 405

5.2.4. A lei aplicável à cláusula penal - o valor da multa condominial estabelecido pelo artigo $1.336, \S 1^{\circ}$, do Código Civil de 2002

5.3. Contratos

5.3.1. A regra geral do Código Civil de 2002 - o artigo 2.035, caput ..... 153

5.3.2. Uma falsa exceção - o artigo 2. 035 , parágrafo único.

5.3.3. Aplicabilidade da teoria da imprevisão a contratos e prestações anteriores ao Código Civil de 2002 - artigos 478 a 480

5.3.4. A possibilidade de o fiador exonerar-se por mera notificação, mesmo nos casos de contrato anterior ao Código Civil de 2002 - os artigos 835 e 2.036

5.4. Responsabilidade Civil

5.5. Direito das Coisas

5.5.1. As enfiteuses particulares constituídas antes de 11 de janeiro de 2003 - o artigo 2.038

5.5.2. Os prazos de usucapião alterados pelo Código Civil de 2002 - os artigos 2.028 e 2.029

5.5.3. O prazo para a desapropriação judicial do artigo $1.228, \S 4^{\circ}$, do Código Civil de 2002 - o artigo 2.030 .

5.6. Direito de Família 
5.6.1. A lei aplicável ao regime de bens do casamento

5.6.2. A possibilidade de alteração do regime de bens anterior ao Código Civil de 2002 .. 177

5.6.3. A lei aplicável ao regime patrimonial das uniões estáveis anteriores ao Código Civil de 2002 e às Leis no 8.791/94 e 9.278/96. 182

5.6.4. A lei aplicável às questões pessoais do direito de família 186

5.6.5. Casamento entre colaterais - Código Civil de 2002 x Decreto-Lei $n^{\circ} 3.200 / 41$ 187

5.6.6. As sociedades entre cônjuges constituídas antes do Código Civil de 2002 - os artigos 977 e 2.031

5.7. Direito das Sucessões 190

5.7.1. A alteração da ordem de vocação hereditária pelo Código Civil de 2002

5.7.2. A sucessão do companheiro: o choque entre o Código Civil de 1916, as Leis $n^{\circ}$

8.791/94 e 9.278/96 e o Código Civil de 2002

5.7.2.1. A lei aplicável às uniões estáveis iniciadas nos regimes anteriores ao Código Civil de 2002.

5.7.2.2. A questão do direito real de habitação do companheiro no Código Civil de 2002

5.7.2.3. O regime da sucessão do companheiro na hipótese de o artigo 1.790 do Código Civil ser considerado inconstitucional.

5.7.3. A lei aplicável à sucessão testamentária 208

5.7.3.1. Questões relacionadas à forma do testamento. 209

5.7.3.2. Questões relacionadas ao conteúdo do testamento 210

5.7.3.3. Os testamentos anteriores ao Código Civil de 2002 e a novel necessidade de justificação das cláusulas restritivas - o artigo 2.042 .

5.7.4. Direito intertemporal e herança jacente/vacante.

5.7.5. A lei aplicável aos tributos incidentes sobre a sucessão causa mortis - a questão do ITCMD e do IR

\section{SEXTA PARTE. SISTEMAS ESPECIAIS DE DIREITO INTERTEMPORAL}

6.1. Considerações Gerais

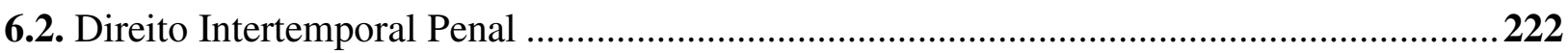

6.2.1. As leis penais benignas - abolitio criminis e novatio legis in mellius ......................224

6.2.2. As leis penais excepcionais e temporárias............................................................226

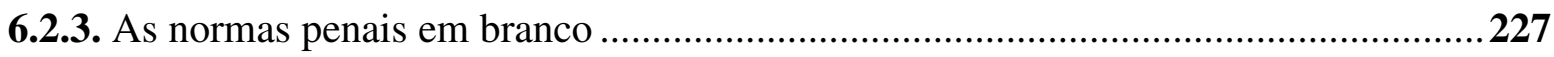

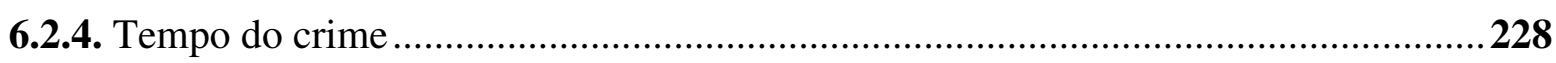

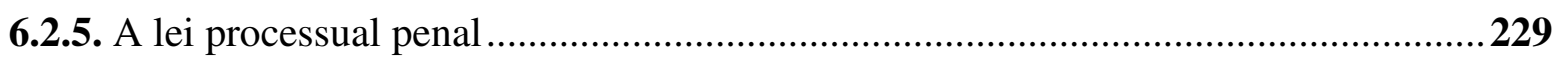

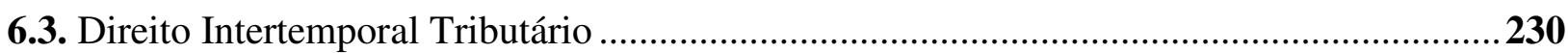




\section{SÉTIMA PARTE. CONCLUSÕES}

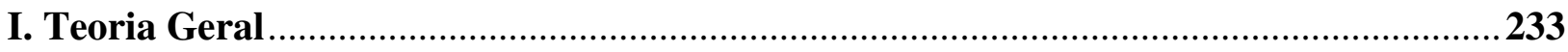

II. Parte Prática.

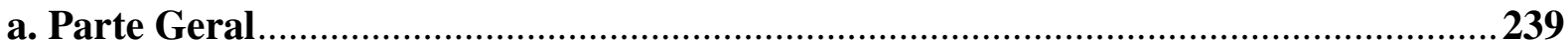

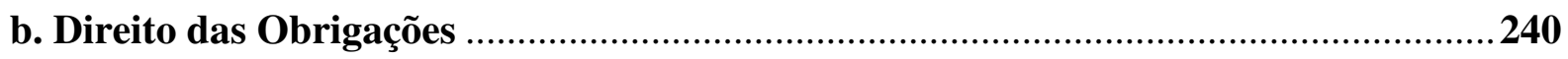

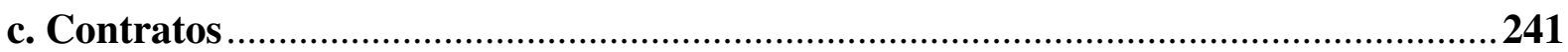

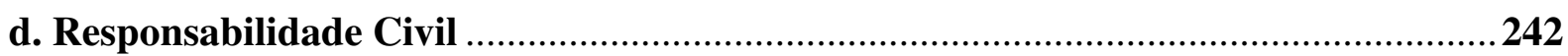

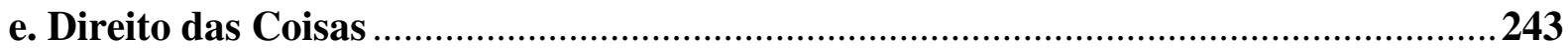

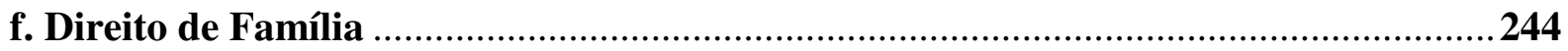

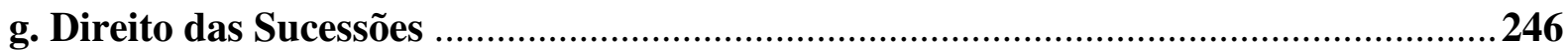

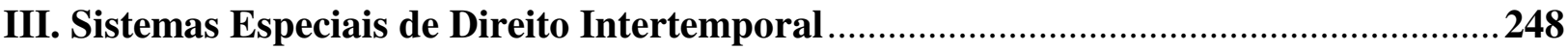

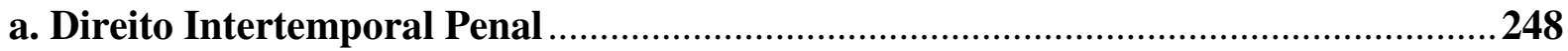

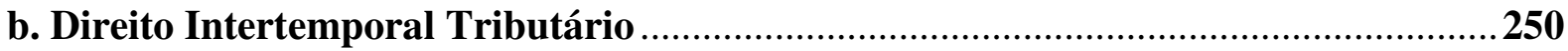

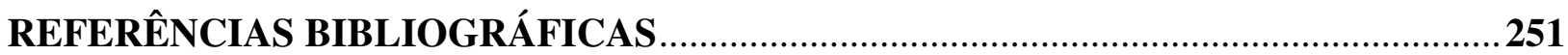

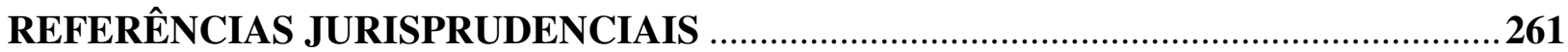




\section{PRIMEIRA PARTE. QUESTÕES INTRODUTÓRIAS}

\subsection{Introdução}

O Direito erige-se sobre um conjunto de regras $^{1}$ tão mutantes quanto os anseios humanos, vivendo o eterno conflito entre o velho e a necessidade de que o novo venha, como sempre vem.

Não por outra razão é que, desde muito cedo, os povos mais primitivos já buscavam formas de solucionar os choques de lei no tempo, cujo estudo milenar acabou por resultar nas regras de direito intertemporal utilizadas hoje. Em um dos mais impressionantes estudos históricos de nosso Direito, Rubens Limongi França demonstra que as primeiras manifestações do direito intertemporal se encontrariam "nos primórdios da vida jurídica da humanidade, pelo menos em estado embrionário"2.

Até alcançar seu contorno atual, a matéria foi objeto de diversos e antagônicos estudos. Os principais deles foram empreendidos por Carlos Francesco Gabba e Paul Roubier, precursores, respectivamente, das teorias do direito adquirido e das situações jurídicas.

Para Carlos Francesco Gabba, "a lei não pode ser retroativa de modo tal que fira direitos adquiridos"3 (para o autor, a lei que age no presente, com efeito imediato, também seria "retroativa", por atingir relações nascidas no passado). Argumenta que, embora o

\footnotetext{
${ }^{1} \mathrm{~A}$ assertiva não pretende definir Direito, mas somente apontar - ainda que de maneira insuficiente - uma de suas características. Embora desejada, uma definição de Direito pressuporia uma capacidade que não temos. De toda forma, tomado como arte, "uma das formas que toma o amor para operar entre os homens", como quer Francesco Carnelutti (in CARNELUTTI, Francesco. Arte do direito: seis meditações sobre o direito. Traduzido por Ricardo Rodrigues Gama. Campinas: Bookseller, 2001. p. 85); seja como "idéia aristotélica de igualdade proporcional", como prega Michel Villey (in VILLEY, Michel. Filosofia do direito: definições e fins do direito: os meios do direito. Traduzido por Márcia Valéria Martinez de Aguiar, revisão técnica de Ari Sólon. São Paulo: Martins Fontes, 2003. p. 93); quer como "instituição social e política complexa, com uma vertente regida por regras (e, nesse sentido, "normativa')", no entendimento de Herbert L.A. Hart (in HART, Herbert L.A. O conceito de direito. 3. ed., com um pós-escrito editado por Penélope A. Bulloch e Joseph Raz, tradução de A. Ribeiro Mendes. Lisboa: Fundação Calouste Gulbenkian, 2001. p. 301) - para ficar no exemplo -, o Direito carregará sempre a idéia de um conjunto de regras, que se com ele não se confunde também dele não se afasta. Para a finalidade deste trabalho, que não se propõe a construções jus-filosóficas mas a uma investigação acerca das formas de resolução dos conflitos de leis no tempo, bastar-nos-á uma noção elementar de Direito, que identificamos como o conjunto de normas destinadas à manutenção da ordem social.

${ }^{2}$ in FRANÇA, Rubens Limongi. Direito intertemporal brasileiro: doutrina da irretroatividade das leis e do direito adquirido. 2. ed. São Paulo: Ed. Revista dos Tribunais, 1968. p. 19.

${ }^{3}$ in GABBA, Carlos Francesco. Teoria della retroattività delle leggi. 3. ed. Torino: Torino Unione Tipográfico Editrice, 1891. v. 1, p. 44. Tradução livre de "le leggi non possono essere retroattive in modo di violare diritti acquisiti".
} 
movimento normativo seja importante para o progresso social, a segurança jurídica demanda que certos direitos sejam respeitados pela nova lei. Tais direitos seriam os direitos adquiridos ${ }^{4}$.

Por sua vez, Paul Roubier considera despicienda a noção de direito adquirido, advogando que os conflitos de lei no tempo poderiam ser resolvidos pela adoção de um conceito técnico de retroatividade (que não abrangesse o efeito imediato). Projetando-se do presente para o futuro, a lei nova seria aplicável a situações futuras e em curso, só não regendo situações anteriores a seu advento.

Como na França o efeito retroativo - e somente ele, sem nenhuma proteção específica aos direitos adquiridos - era e é vedado pelo artigo $2^{\circ}$ do Código de Napoleão, Paul Roubier pugnou pelo abandono da teoria dos direitos adquiridos, pois o efeito imediato da lei nova atingiria inclusive estes, à exceção de casos especiais, como dos contratos ${ }^{5}$.

\footnotetext{
${ }^{4}$ Expressão utilizada com o significado de "pertencente mas ainda não exercido", e não com o que, em português, uma primeira leitura poderia indicar, de "todo direito que passou ao patrimônio de alguém". O ponto fica claro na passagem seguinte: "na teoria da retroatividade, a expressão 'direito adquirido' não se prende ao seu significado mais geral, que compreenderia também os direitos consumados, mas significa propriamente e somente aqueles direitos que foram adquiridos mas ainda não estão consumados". Tradução livre de: “(...) nella teoria della retroattività l'espressione 'diritti acquisiti' non si prende nel suo significato piú generale, che comprenderebbe anche i diritti consumati, ma significa propriamente $e$ soltanto quei diritti che furonio acquistati, ma "non sono ancora stati effettuati o consumati" (GABBA, Carlos Francesco. op. cit., p. 191).

${ }^{5}$ Eis a lição de Paul Roubier: "O efeito retroativo da lei é estritamente proibido pelo artigo $2^{\circ}$ do Código Civil: o intérprete deverá definir a retroatividade e proscrever toda a aplicação retroativa da lei.

Ao contrário, o efeito imediato da lei constitui o direito comum; nós veremos que, em princípio, uma lei nova deve receber aplicação logo, mesmo nas situações em curso, a partir do dia de sua entrada em vigor. E é somente no que concerne às partes anteriores de uma situação em curso que a nova lei não poderia ter ação sem retroatividade.

Essa diferença é fundamental e ela constitui uma oposição absoluta entre esses dois modos de aplicação da lei no tempo.

Entretanto, em certas matérias, o efeito imediato é excluído e também o efeito retroativo; é assim para os contratos em curso, que não são, em princípio, tocados pelas leis novas, nem pelas partes anteriores à lei nova, nem mesmo pelos seus efeitos que venham a acontecer. A regra é aqui a sobrevivência da lei antiga: o efeito imediato e o efeito retroativo, excluídos, parecem então se juntar numa região comum onde suas fronteiras se apagam. No entanto, seria um erro acreditar nisso, e nós pensamos que, mesmo então, subsistem outros interesses na distinção das duas espécies de efeitos (...)" (in ROUBIER, Paul. Les conflits de lois dans le temps (théorie dite de la non-rétroactivité des lois). Paris: Librairie du Recuiel Sirey, 1929. p. 374-375). Tradução livre de: "L'effet retroactif de la loi est estrictement prohibé par l'article 2 du Code Civil: l'interprète devra dèfinir la rétroactivité et proscrite toute application rétroactive de la loi.

Au contraire, l'effet immédiat de la loi constitue le droit commun; nous verrons qu'en principe, une loi nouvelle doit recevoir aussiôt application, mème dans les situations en cours, a partir du jour de son entrèe en viguer. Et c'est seulement en ce qui concerne les parties antérioeures d'une situation en cours que la loi nouvelle ne pourrait avoir action sans rétroactivité.

Cette différence est fundamentale et elle constitue une opposition absolue entre ces deux modes d'application de la loi dans le temps.

Cepedant, dans certaines matières, l'effet immédiat est exclu aussi bien l'effet rétroactif; il en est ainsi pour les contrats en cours, qui ne sont pas en principe touchés par les lois nouvelles, ni pour les parties antérieures à la loi nouvelle, ni même pour leurs effets à venir. La règle est ici la sourvie de la loi ancienne: l'effet immédiat et l'effet retroactif, tous deux exclus, semblent alors se rejoindre dans une région commune et leurs frontières s'effacer. Ce serait cepedant une erreur de le croire et nous pensons que, même alors, il sobsiste d'autres intérêts à la distinction des deux sortes d'effets (...)".
} 
No Brasil, coube ao mestre Rubens Limongi França a tarefa de construir uma doutrina nacional sobre o tema, para o que empreendeu um minudente resgate das origens do direito intertemporal brasileiro. Em trabalho detalhado e absolutamente coerente sob o ponto de vista histórico, o autor comprovou que o direito intertemporal brasileiro sempre conviveu harmonicamente com a proteção do direito adquirido e a regra do efeito imediato.

A partir desta premissa, Rubens Limongi França vai propor, na conclusão de sua obra, a adoção de técnica que leve em conta ambas as máximas - do efeito imediato e da proteção do direito adquirido -, afirmando que "a despeito do efeito imediato, a atuação das leis encontra limite no Direito Adquirido"6.

Deveriam ter cessado as discussões sobre o direito intertemporal. No entanto, talvez pelo costume de importar do direito estrangeiro regras que não se alinham ao sistema de direito intertemporal brasileiro, a questão parece complicar-se cada dia mais nas penas da doutrina e dos tribunais, mormente pela adoção de um conceito equivocado de retroatividade e de soluções que, indevidamente, contrapõem as regras da proteção do direito adquirido e do efeito imediato, sem compatibilizá-las.

Veja-se, por exemplo, o que se lê na seguinte afirmação, tirada de um dos mais emblemáticos julgamentos acerca do direito intertemporal: "se a lei alcançar os efeitos futuros de contratos celebrados anteriormente a ela, será essa lei retroativa (retroatividade mínima) porque vai interferir na causa, que é um ato ou fato ocorrido no passado"7; há aí confusão evidente entre os conceitos de efeito imediato e retroativo, o que comprovaremos ao tratar especificamente do tema.

Daí o primeiro objetivo deste trabalho, rememorar conceitos do direito intertemporal brasileiro, refutando a adoção de regras alienígenas que para nós nada dizem, mas apenas complicam. Ainda dentro deste objetivo, desenvolver a matéria de uma forma mais prática, de modo que as teorias propostas por Rubens Limongi França encontrem nos tribunais o eco merecido mas ainda não experimentado ${ }^{8}$.

\footnotetext{
${ }^{6}$ in FRANÇA, Rubens Limongi. op. cit., p. 510.

${ }^{7}$ STF, Pleno, ADIN no 492-0/DF, Rel. Min. Moreira Alves, j. 25.6.1992, votação por maioria. Este julgado será explicado no item 4.2.1.

${ }^{8} \mathrm{O}$ que talvez tenha se dado em razão do enfoque demasiadamente acadêmico dado à sua obra, o que ele mesmo reconheceu ao lançar uma edição condensada de $O$ direito intertemporal brasileiro (in FRANÇA, Rubens Limongi. A irretroatividade das leis e o direito adquirido. 3. ed. refun. e atual. do "Direito intertemporal brasileiro". São Paulo: Ed. Revista dos Tribunais, 1982).
} 
Paralelamente, observar que, tendo sido escrita antes da Constituição Federal de 1988 quando a proteção do direito adquirido veio a ser inscrita no rol dos direitos fundamentais -, a inestimável obra de Rubens Limongi França poderia ser repensada no que toca aos limites da proteção do direito adquirido, que o mestre sugerira ser a ordem pública, mas deixando a questão em aberto.

Refutando o critério da ordem pública, delinearemos critério outro - que chamamos de "ponderação na origem" -, que não nos parece novo nem infalível, mas a nosso ver se amolda ao direito intertemporal brasileiro. Fazemo-no inspirado em fantástico voto vencido do Ministro Ruy Rosado de Aguiar, no qual pondera que, para aplicar o artigo 53 do Código de Defesa do Consumidor a contratos anteriores a seu advento, não seria necessário recorrer-se à dicotomia direito adquirido versus ordem pública, dado que a vedação contida neste dispositivo - a perda das parcelas pagas em favor do fornecedor, em caso de inadimplemento - já estava implícita no sistema jurídico antes do diploma consumerista ${ }^{9}$. O raciocínio será útil para embasar tantas outras questões modernas do direito intertemporal, como por exemplo a constitucionalidade do artigo 2.035, parágrafo único, do Código Civil de 2002.

\subsection{As duas teorias que mais influenciaram o direito intertemporal brasileiro}

Embora divirjam quanto à forma de conceituar a retroatividade, modernamente Carlos Francesco Gabba e Paul Roubier foram igualmente importantes para o sistema de direito intertemporal brasileiro $^{10}$ : se de um lado a Lei de Introdução ao Código Civil abraçou a regra do efeito imediato, propugnada por Paul Roubier, de outro, a Constituição Federal e a própria Lei de Introdução ao Código Civil não deixaram de lado a proteção do direito adquirido, cujas linhas mestras foram delineadas por Carlos Francesco Gabba.

Como se verá no capítulo dedicado à obra de Rubens Limongi França, o direito intertemporal brasileiro experimentou uma simbiose entre uma e outra teorias, assumindo peculiaridades que não permitem resolver os conflitos de lei no tempo somente por esta ou por aquela doutrina. Ao resolver os problemas de direito intertemporal, o intérprete deverá

\footnotetext{
${ }^{9}$ STJ, $44^{\mathrm{a}}$ Turma, REsp no 45.666/SP, Rel. Min. Barros Monteiro, j. 17.5.1994, votação por maioria. Este julgado está explicado no item 4.2.4.

${ }^{10}$ Há diversas outras teorias sobre o tema, como demonstra Rubens Limongi França (in FRANÇA, Rubens Limongi. Direito intertemporal brasileiro: doutrina da irretroatividade das leis e do direito adquirido, cit.). Contudo, a nosso ver as doutrinas de Carlos Francesco Gabba e Paul Roubier sintetizam a formação do direito intertemporal brasileiro, razão pela qual nos deteremos a esses dois autores.
} 
partir do pressuposto de que a lei opera com efeito imediato - abraçando Paul Roubier -, mas não se olvidando de que este efeito encontra limite no direito adquirido - conforme o propugnava Carlos Francesco Gabba.

Por essa razão, analisaremos de maneira breve a doutrina de cada um deles, estudando em seguida, na obra de Rubens Limongi França, como se operou, no Brasil, essa simbiose entre a doutrina do direito adquirido e a regra do efeito imediato.

\title{
1.2.1. A doutrina de Carlos Francesco Gabba - a teoria da proteção do direito adquirido
}

Carlos Francesco Gabba parte do pressuposto de que, ao atuar, no presente, sobre fatos nascidos antes de seu advento, a lei operaria retroativamente, o que era e é vedado por sistemas europeus, como o italiano. Apercebendo-se, porém, de que não se poderia impedir a aplicação da lei nova em todo e qualquer caso, delineou teoria segundo a qual a retroatividade - aqui entendida, repita-se, como a aplicação da norma a fatos em curso - seria permitida desde que não ofendesse direitos adquiridos.

Demonstra Carlos Francesco Gabba que, em toda a história da humanidade, os povos procuraram destruir instituições ultrapassadas, sob a crença de que tal abolição seria feita em razão de justiça:

\begin{abstract}
"Encontram-se leis dessa natureza na história de todos os povos, porém raras e quase sempre de épocas revolucionárias, quando um povo destrói instituições que se tornaram incompatíveis com idéias e tendências em que se sustentavam. Quase sempre, também, a abolição de instituições existentes se faz em nome dos princípios de justiça que sempre existiram (...)" ${ }^{\text {"11 }}$.
\end{abstract}

Contudo, sustenta que esses mesmos povos jamais admitiram que a lei nova atingisse direitos adquiridos, o que representaria retroatividade "injusta", e, portanto, não admitida pelo sistema jurídico. Daí concluir o autor que a retroatividade seria natural e admitida desde que "justa", isto é, desde que não atingisse direitos adquiridos. Por isto, o direito adquirido

\footnotetext{
${ }^{11}$ in GABBA, Carlos Francesco. op. cit., p. 33. Tradução livre de "Leggi di questa natura si incontrano nella storia di tutti i populi civili, di rado però, e quasi sempre in epoche di revoluzione, allorquando un popolo distrugge istituzioni diventate incompatibili colle idee e colle tendenze che in lui sottentrarono alle antiche. Quasi sempre eziandio le abolizioni di esistenti instituizioni si fanno in nome di principi di giustizia che hanno sempre esistito (...)".
} 
seria o único limite à eficácia da lei nova: “(...) o verdadeiro e próprio limite à eficácia da lei nova sobre fatos e relações jurídicas anteriores sempre foi reconhecido (...) serem (...) os (...) direitos adquiridos mediante estes fatos e relações jurídicas (...)"12.

Um dos primeiros autores brasileiros a estudar a obra de Carlos Francesco Gabba, Reynaldo Porchat afirma:

"Quando, ao executar-se uma lei nova qualquer, depara-se um direito
adquirido que possa ser lesado, a lei não tem aplicação ao caso, porque a
retroactividade seria injusta. Quando não se encontra direito adquirido,
applica-se a lei, mesmo retroactivamente, porque a retroactividade é
justa"13.

A partir de tais premissas, Carlos Francesco Gabba vai analisar as várias formas de aquisição de direitos, demonstrando em seguida como se aplica a lei no tempo em cada ramo do Direito. Regendo-se por princípios diversos e constituindo-se de forma diferente cada um dos direitos, o intérprete não poderia traçar uma só regra para a análise do direito adquirido, havendo de verificar, no caso a caso, se este se configura.

Como, entre nós, o direito adquirido goza de proteção constitucional e legal, esta busca não será mera opção teórica, mas verdadeira obrigação. Se é verdade que o direito adquirido não deve ser utilizado para o estabelecimento de um conceito de retroatividade, como pretendia Carlos Francesco Gabba, este será imprescindível para determinar as hipóteses de ultratividade da lei revogada. Tais conceitos serão delineados em diversas passagens deste trabalho.

\subsubsection{A doutrina de Paul Roubier - a teoria das situações jurídicas}

Paul Roubier parte da premissa de que, ao atuar, no presente, sobre fatos e relações nascidas no passado, a lei operaria com efeito imediato, e não com efeito retroativo - não incidindo, pois, na proibição que muitos ordenamentos europeus traçam à retroatividade, como é o caso do sistema francês. A lei nova poderia atingir todos os fatos e relações em curso, só não se voltando para o passado, ou seja, sobre fatos ocorridos antes do seu advento.

\footnotetext{
${ }^{12}$ GABBA, Carlos Francesco. op. cit., p. $42-43$ e 180. Tradução livre de “(...) Il vero e proprio limite alla efficacia delle leggi nuove sui fatti e rapporti giuridici anteriori fu sempre riconosciuto (...) essere (...) $i$ (...) diritti acquisiti mediante quei fatti e rapporti (...)".

${ }^{13}$ in PORCHAT, Reynaldo. Da retroactividade das leis civis. São Paulo: Duprat \& Comp., 1909. p. 8.
} 
Para o autor, os conflitos de lei no tempo poderiam ser resolvidos pela seguinte fórmula: se a lei dispuser sobre um fato ocorrido no passado, haverá retroatividade, vedada pelo artigo $2^{\circ}$ do Código de Napoleão; se pretender aplicar-se aos fatos presentes e futuros, não incidirá nesta proibição; atuando sobre os fatos pendentes - que nascem no passado e se prolongam para depois da revogação da norma que lhes disciplinava -, estabelece-se um corte entre os fatos anteriores e posteriores à lei nova, aplicando-se-a somente dali em diante, às partes posteriores, sob pena de incidir em retroatividade, vedada pelo artigo $2^{\circ}$ do Código de Napoleão:

\begin{abstract}
"A base fundamental da ciência dos conflitos de leis no tempo, é a distinção do efeito retroativo e do efeito imediato da lei. Isso parece ser algo muito simples: o efeito retroativo é a aplicação no passado; o efeito imediato, aplicação no presente; não parece ser tão difícil definir e distinguir esses dois momentos da duração. Se pretendemos aplicar a lei a fatos realizados (facta praeterita), ela é retroativa; se pretendemos aplicá-la em situações em curso (facta pendentia), será preciso estabelecer uma separação entre as partes posteriores, pelas quais a lei nova, se ela deve ser aplicada, não terá nada mais do que um efeito imediato; enfim, face aos fatos que virão (facta futura), é claro que a lei não pode ser jamais retroativa" ${ }^{\prime 14}$.
\end{abstract}

Para o estabelecimento desse "corte", Paul Roubier abandona o conceito de direito adquirido, adotando o de situação jurídica. $\mathrm{O}$ autor não vai perquirir se a lei nova se choca com um direito adquirido, mas sim se ela (lei) adveio antes ou depois de determinada situação jurídica. Esta, no dizer de José de Oliveira Ascensão, "é a resultante universal da aplicação duma norma jurídica" ${ }^{15}$, que possui um sentido muito mais amplo do que o de direito adquirido, pois não possui caráter subjetivo e pode existir "mesmo que não se tratasse de situações de um sujeito (...). A norma meramente qualificativa de coisas, como imóveis ou fungíveis, sendo uma norma jurídica, provocaria na sua aplicação situações jurídicas sem titular"16.

\footnotetext{
${ }^{14}$ in ROUBIER, Paul. op. cit., p. 371. Tradução livre de: "La base fondamentale de la science des conflits de lois dans le temps, c'est la distinction de l'effet rétroactif et de l'effet immédiat de la loi. Cela paraît une donnée très simple : l'effet rétroactif, c'est l'application dans le passé ; l'effet immédiat, l'application dans le présent; il ne paraît pas très malaisé de définir et de distinguer ces deux moments de la durée. Si la loi prétend s'appliquer à des faits accomplis (facta praeterita), elle est rétroactive; si elle prétend s'appliquer des situations en cours (facta pendentia), il faudra établir une séparation entre les parties postérieures, pour lesquelles la loi nouvelle, si elle doit s'appliquer, n'aura jamais qu'un effet immédiat ; enfin, vis-à-vis des faits à venir (facta futura), il est clair que la loi ne peut jamais être rétroactive”.

${ }^{15}$ in ASCENSÃO, José de Oliveira. Direito civil: teoria geral: relações e situações Jurídicas. Coimbra: Coimbra Ed., 2002. p. 11.

${ }^{16}$ Id. Ibid.
} 
Paul Roubier observa que a maioria das situações jurídicas não se opera em um único momento, podendo, em algumas hipóteses, ser alcançada pela incidência da lei nova. Essa incidência pode ocorrer na fase de formação ou de extinção da situação jurídica - o que chama de "fase dinâmica" - ou quando estiver produzindo efeitos - o que denomina "fase estática". No caso de leis que criam ou extinguem situações jurídicas, atuando na fase dinâmica, seria retroativa - e, portanto, proibida pelo artigo $2^{\circ}$ do Código de Napoleão - aquela que considera fatos ocorridos antes de sua entrada em vigor ${ }^{17}$. Quando atua na fase estática, regulando situações jurídicas já consolidadas, seria retroativa apenas se atingisse os efeitos produzidos sob a égide da lei revogada (podendo, no entanto, atingir os efeitos posteriores). Exceção a estas regras existiria somente para casos especiais, como dos contratos.

Como é evidente, a teoria de Paul Roubier terá grande importância, no sistema de direito intertemporal brasileiro, na fixação de um conceito de retroatividade e na determinação dos fatos a serem atingidos pela lei nova. Contudo, tal regra deverá ser conciliada com a da proteção do direito adquirido - abandonando-se a idéia de situação jurídica, que não tem albergue no direito intertemporal brasileiro. Nossa fórmula de direito intertemporal será a de que a lei nova se aplica desde logo a todos os fatos anteriores e pendentes, respeitados o direito adquirido, o ato jurídico perfeito e a coisa julgada.

\footnotetext{
17، O ciclo de desenvolvimento de uma situação jurídica compreende três momentos, o momento de sua constituição, o momento de seus efeitos e o momento de sua extinção. O primeiro e o terceiro momento representam a dinâmica; o segundo, a estática dessa situação.

Nós devemos, portanto, naturalmente, falar, em primeiro lugar, do momento da constituição, para seguir a ordem cronológica; mas as regras são as mesmas para o momento da extinção e existe uma assimilação forçada entre essas duas formas de dinamismo jurídico; de outro lado, acontece que a maneira de extinção de uma situação jurídica é, ao mesmo tempo, uma maneira de constituição de uma outra situação (conversão de uma separação de corpos no divórcio, por exemplo)" (ROUBIER, Paul. op. cit., p. 381-382). Tradução livre de: "Le cycle de développement d'une situation juridique comprend trois moments, le moment de sa constitution, le moment de ses effets et le moment de son extinction. Le premier er le troisième moments représentent da dynamique, le deuxième la statique de cette situation.

Nous devons donc naturellment parler d'abord du moment de la constitution, pour suivre l'ordre chronologuque; mais les ràglesmsont les mêmes pour le moment de l'extinction, et il y a une assimilation forcée entre ces deux formes de dynamisme juridique; il arrive d'ailleurs qu'un mode d'extinction d'une situation juridique est en même temps un mode de constitution d'une autre situation (conversion d'une séparation de corps en divorce, par exemple)".
} 


\subsection{A doutrina brasileira de Rubens Limongi França - o resgate histórico da tradição jurídica nacional}

A divergência instaurada entre os partidários das doutrinas do direito adquirido e das situações jurídicas fez com que autores brasileiros adotassem essa ou aquela de maneira excludente, resolvendo os problemas de direito intertemporal como se fossem incompatíveis.

Contudo, outros se aperceberam de que, diferentemente de alguns sistemas europeus, o direito intertemporal brasileiro possui peculiaridades que não permitem acatar uma teoria em detrimento da outra, por exemplo, negando-se o efeito imediato ao se tratar do direito adquirido ou simplesmente abandonando-se este em detrimento daquel'outra regra.

Diante dessa constatação, Rubens Limongi França se propôs a resgatar as origens do direito intertemporal brasileiro, de forma a "reunir e sistematizar subsídios para uma Doutrina Brasileira do Direito Intertemporal em matéria civil"18. Para tanto, o grande Professor levou a cabo um magnífico estudo sobre as origens do direito intertemporal brasileiro, indicando qual orientação deveria ser adotada em uma doutrina nacional sobre o tema ${ }^{19}$.

\footnotetext{
${ }^{18}$ in FRANÇA, Rubens Limongi. Direito intertemporal brasileiro: doutrina da irretroatividade das leis e do direito adquirido, cit., p. 10.

${ }^{19} \mathrm{O}$ ponto merece uma observação: a obra de Rubens Limongi França normalmente é lida como se o estudo histórico ali empreendido fosse apenas um grande e longo capítulo de sua tese - o que é claro naqueles autores que simplesmente reproduzem suas investigações a título de mera curiosidade jurídica. Contudo, para que se tire o maior proveito desta magnífica obra, que rendeu a seu autor o título de Professor Catedrático da Faculdade de Direito da Universidade de São Paulo, é preciso ter em conta que toda essa investigação histórica teve como objetivo a construção das bases para uma doutrina brasileira de direito intertemporal, que pretendia evitar que autores brasileiros importassem para o nosso Direito teorias que não guardam relação com as nossas tradições jurídicas. A defesa do autor é feita por ele mesmo, já no início de sua obra, onde diz: "O objeto do presente trabalho é reunir e sistematizar subsídios para uma Doutrina Brasileira do Direito Intertemporal em matéria civil.

Tríplice é a sua razão de ser: a circunstância de não termos uma ciência nacional a respeito da matéria; a particularidade de podermos ter uma tal ciência; e o fato de ser necessário que a tenhamos.

$\mathrm{Na}$ verdade, a despeito do inegável valor de muitas obras que, entre nós, se escreveram relacionadas com o tema, nenhuma delas apresenta feição caracteristicamente brasileira, sendo comum filiarem-se a êste ou àquele autor alienígena, muitas vêzes sem qualquer consonância com a nossa realidade sócio-jurídica, e até mesmo sem conexão alguma com o nosso próprio direito positivo em vigor.

Sob outro aspecto, não há para isso nenhuma explicação cientificamente plausível, pois, conforme se terá ocasião de demonstrar, existem, em meio às fontes da nossa melhor tradição jurídica, um farto, belo e constante manancial de elementos que nos possibilitariam estruturar, sôbre o assunto, mais do que a maioria dos povos cultos, uma doutrina de índole bàsicamente nacional, de grande significado para a autonomia cultural (no sentido técnico) do nosso país.

Por fim, é efetivamente de mister seja essa uma das preocupações dos nossos juristas, pois se, de um lado, grande é a confusão reinante entre muitos dos nossos autores a respeito da matéria, graças, em grande parte, ao seu desarraigamento das nossas melhores tradições, do outro, de especial relevância é o significado do assunto, por isso que se entende com o respeito aos direitos individuais e à própria segurança e estabilidade jurídica do nosso país" (Id. Ibid., p. 10-11).
} 
O professor começa longe, demonstrando que já no direito egípcio se encontravam manifestações primitivas de ultratividade da lei revogada. Em uma época em que as crenças religiosas exerciam grande influência sobre as relações jurídicas, os devedores que se sentissem extorquidos por seus credores poderiam ser liberados pelos deuses, mediante um juramento, utilizando a religião como meio de extinção das obrigações. Como forma de neutralizar esta interferência do faz no jus, porém, o Código de Bocchoris ${ }^{20}$ veio dispor que, ao contrair a dívida, o devedor deveria rezar uma oração solene que o impediria de apelar aos deuses, em "uma das primeiras manifestações da cisão entre a lei nova e a antiga, bem assim de preservação do Direito Adquirido do credor. (...) o Direito Adquirido aqui não é garantido contra a retroatividade da lei nova, senão à face da ultra-atividade da lei velha"21.

No direito mesopotâmico, Rubens Limongi França verificou que todos os soberanos deviam obediência ao príncipe da Babilônia, cujas ordens deveriam seguir, sob pena de severas maldições. Vê aí o que reputa "várias indicações importantes: o estado de direito, a subordinação dos soberanos à lei, a linha divisória entre o direito antigo e o direito nôvo",22.

Já nos velhos códigos indianos, constatou que existia, no direito hindu, uma "subordinação da suprema autoridade aos princípios por ela mesma estabelecidos" que a seu ver "não deixa de constituir, por si só, um embrião do respeito ao Direito Adquirido dos súditos, tanto mais que a recomendação é insistentemente repetida (...)"24.

No direito hebraico, apesar de não encontrar nenhuma manifestação centrada no princípio da irretroatividade, o professor a vê evidenciada como "corolário desta reverência à pessoa humana, pois é um dos meios de preservação da sua paz e da sua segurança"25, concluindo que "se, tècnicamente, não lhe deparamos a formulação na Lei Mosaica, aí se encontra, entretanto, o germe de uma concepção jurídica, que, mais tarde, veio a permitir alcançar êsse princípio amplitude muito maior do que a do Direito Clássico"26.

Ainda analisando o direito oriental, Rubens Limongi França observa que, apesar das poucas manifestações sobre o direito intertemporal - o que se deve à filosofia, lá dominante, segundo a qual o homem é naturalmente bom e deve ser governado por exemplos e não por

\footnotetext{
${ }^{20}$ Primeiro Código egípcio de que se tem notícia, elaborado por volta de 715 a.C.

${ }^{21}$ FRANÇA, Rubens Limongi. op. cit., p. 22.

${ }^{22}$ Id. Ibid., p. 24.

${ }^{23}$ Id. Ibid., p. 26.

${ }^{24}$ Id. Ibid.

${ }^{25}$ Id. Ibid., p. 29-30.

${ }^{26}$ Id. Ibid., p. 30.
} 
códigos -, na China “(...) com a promulgação dos novos códigos, o princípio da irretroatividade das leis foi rica e minuciosamente adotado"27.

Passando ao direito clássico, Rubens Limongi França demonstra que os gregos "tinham a noção da revogação da lei antiga pela lei nova; a lei antiga podia permanecer se considerada justa; essa lei antiga era então confirmada e o seu texto afixado em lugar público"28. Fazendo uma breve análise das primeiras manifestações do direito romano - no qual o professor não encontra evidências do princípio da irretroatividade -, dá por encerrada a fase "embrionária" do direito intertemporal.

O período seguinte, chamado de fase "pré-científica", é analisado por Rubens Limongi França em três momentos distintos, quais sejam, o direito romano pré-clássico, o direito intermédio e o direito moderno.

Quanto ao direito romano pré-clássico, Rubens Limongi França assinala que (1) o período se inicia em torno de 150 a.C. ${ }^{29}$; (2) a noção da irretroatividade esteve bastante arraigada durante o período, o que se poderia notar nos textos de Paulo e Ulpiano, a quem se deve a primeira fórmula referente aos limites da retroatividade: quae judicata transacta finitave sunt ${ }^{30}$; (3) com a Primeira e a Segunda Regras Teodosianas, firma-se a regra da irretroatividade, mormente pela noção dos facta pendentia ${ }^{31}$; (4) com o Código e as Novelas de Justiniano, produziu-se um primeiro esboço de sistema de direito intertemporal ${ }^{32}$.

No que toca ao direito intermédio, merecem reprodução, para uma apertada síntese: (1) nos ordenamentos bárbaros permanece a noção de irretroatividade, assim como a de facta praeterita e facta pendentia ${ }^{33}$; (2) de especial importância é a Lex Wisigothorum, do rei Flávio Recesvindo, que vigorou em Portugal até as Ordenações Afonsinas e contribuiu, para o direito intertemporal brasileiro, com a regra do efeito imediato ${ }^{34}$; (3) entre os códigos ibéricos primitivos, deve ser realçado o Fuero de Cuenca, de Afonso VIII - primeiro grande ordenamento depois da reconquista -, pois vai reproduzir a regra do efeito imediato ${ }^{35}$; (4) no direito canônico medieval é delineado o conceito de Ius Quaesitum, com Bonifácio

\footnotetext{
${ }^{27}$ FRANÇA, Rubens Limongi. op. cit., p. 32.

${ }^{28}$ Id. Ibid., p. 34.

${ }^{29}$ Id. Ibid., p. 41 e ss.

${ }^{30}$ Id. Ibid., p. 46 e ss.

${ }^{31}$ Id. Ibid., p. 55 e ss.

${ }^{32}$ Id. Ibid., p. 59 e ss.

${ }^{33}$ Id. Ibid., p. 74 e ss.

${ }^{34}$ Id. Ibid., p. 76 e ss.

${ }^{35}$ Id. Ibid., p. 82 e ss.
} 
VIII ${ }^{36}$; e (5) a doutrina medieval dos pós-glosadores, principalmente com Felinus Sandaeus, estabeleceu diferença entre o direito adquirido e a expectativa de direito ${ }^{37}$.

No direito moderno da fase pré-científica, Rubens Limongi França assinala que (1) a legislação italiana, apesar de fragmentária - o que se prolongou até a unificação, ocorrida em meados do século XIX -, abraça o princípio da irretroatividade ${ }^{38}$; (2) a legislação germânica abarca importantes regras de direito transitório, principalmente no Ladrecht prussiano, de $1794^{39}$; (3) a legislação francesa é confusa e teria experimentado um retrocesso com o artigo $2^{\circ}$ do Código de Napoleão ${ }^{40}$; (4) a mais significativa contribuição legislativa do período é encontrada na Constituição dos Estados Unidos da América, que eleva o princípio da irretroatividade a nível constitucional ${ }^{41}$.

Na sequiência, Rubens Limongi França realiza um estudo da fase científica do direito intertemporal. Com relação à legislação do período, o professor demonstra que a maioria dos países, influenciada pelo direito francês, não consagra o princípio da irretroatividade em nível constitucional, a não ser em matéria penal. Em nível ordinário, divide o direito estrangeiro em dois grupos: o primeiro, daqueles países que apenas abraçam a regra da não-retroatividade, sem se referir ao direito adquirido - por exemplo, França, Itália, Holanda, Uruguai, Venezuela e Bolívia -; o segundo, dos países que, além de albergar o princípio da irretroatividade, referem-se ao direito adquirido como limite à ação da lei nova - por exemplo, Áustria, Portugal e Argentina ${ }^{42}$.

Quanto à doutrina, Rubens Limongi França analisa um a um os autores que abraçaram a teoria do direito adquirido ${ }^{43}$, com grande destaque para Calos Francesco Gabba ${ }^{44}$. Conclui ter sido de grande importância a contribuição deste autor, merecendo ele, no entanto, adaptação aos vários sistemas de direito positivo e à natural evolução da doutrina clássica ${ }^{45}$.

\footnotetext{
${ }^{36}$ FRANÇA, Rubens Limongi. op. cit., p. 88 e ss.

${ }^{37}$ Id. Ibid., p. 97 e ss.

${ }^{38}$ Id. Ibid., p. 103 e ss.

${ }^{39}$ Id. Ibid., p. 105 e ss.

${ }^{40}$ Id. Ibid., p. 107 e ss.

${ }^{41}$ Id. Ibid., p. 112 e ss.

${ }^{42}$ Id. Ibid., p. 125 e ss.

${ }^{43}$ Id. Ibid., p. 130 e ss.

${ }^{44}$ Id. Ibid., p. 151 e ss.

${ }^{45}$ Id. Ibid., p. 526.
} 
Em seguida, analisa os autores contrários ${ }^{46}$, com maior evidência a Paul Roubier ${ }^{47}$. Refutando a idéia de "situação jurídica", conclui que o mérito dessa teoria está no fato de ter delineado as linhas mestras da regra do efeito imediato ${ }^{48}$.

Por fim, Rubens Limongi França passa à análise da formação do direito intertemporal brasileiro, que, segundo ensina, processou-se em três fases: o período anterior à Independência, a fase do Brasil independente e o período posterior ao Código Civil de 1916.

A fase anterior à Independência tem início com a formação da nação lusitana, em 1139, quando ainda vigoravam os códigos visigóticos, que adotavam a regra do efeito imediato $^{49}$. Posteriormente, o princípio da irretroatividade vai ser relembrado em diversas disposições das Ordenações Afonsinas, Manoelinas e Filipinas, com exceção às matérias de ordem pública $^{50}$. No final do período pré-independência, as regras intertemporais se mantêm, apesar de o Estado luso assumir feições absolutistas ${ }^{51}$.

Com a proclamação da independência, ao lado das ordenações de D. Filipe é promulgada a Constituição de 1824, que dispõe expressamente, no artigo 179, sobre a nãoretroatividade das leis civis ${ }^{52}$. A mesma regra é mantida na Constituição republicana de 1891 , principalmente pela influência de Rui Barbosa53. A legislação ordinária guardou a tradição de que o direito adquirido deve ser preservado, salvo nos casos de confronto com a ordem pública ${ }^{54}$.

Rubens Limongi França ensina ainda que a atual fórmula de proteção do direito adquirido surge no Projeto de Coelho Rodrigues, com quase total correspondência às disposições intertemporais da Lei de Introdução ao Código Civil - com exceção à regra do efeito imediato, que, no referido projeto, dava lugar à proibição da retroatividade ${ }^{55}$. Com relação à doutrina do período, o professor entende tenha ela se aliado à doutrina do direito adquirido, com destaque à obra de Reynaldo Porchat ${ }^{56}$.

\footnotetext{
${ }^{46}$ FRANÇA, Rubens Limongi. op. cit., p. 165 e ss.

${ }^{47}$ Id. Ibid., p. 174 e ss.

${ }^{48}$ Id. Ibid., p. 527.

${ }^{49}$ Id. Ibid., p. 254 e ss.

${ }^{50}$ Id. Ibid., p. 261 e ss.

${ }^{51}$ Id. Ibid., p. 275 e ss.

${ }^{52}$ Id. Ibid., p. 284.

${ }^{53}$ Id. Ibid., p. 285.

${ }^{54}$ Id. Ibid., p. 286 e ss.

${ }^{55}$ Id. Ibid., p. 295 e ss.

${ }^{56}$ Id. Ibid., p. 302 e ss.
} 
Na fase posterior à promulgação do Código Civil, Rubens Limongi França chama atenção para a consolidação da fórmula brasileira do direito intertemporal, com a primeira Lei de Introdução ao Código Civil $^{57}$, que vai ser violentada com a promulgação da Constituição de 1937 e pela Lei de Introdução ao Código Civil de $1942^{58}$, mas depois retomada com a reforma de $1957^{59}$.

Em apertadíssima síntese, esse é o regate histórico das origens do direito intertemporal brasileiro, que o mestre Rubens Limongi França traça de maneira profunda, analisando cada autor, de cada período.

Feita toda essa extensa e profunda análise, Rubens Limongi França expõe suas orientações para a resolução dos problemas de direito intertemporal ${ }^{60}$, enfrentando a questão das leis interpretativas ${ }^{61}$, da regra do efeito imediato no sistema ordinário ${ }^{62}$ e os direitos de aquisição complexa ${ }^{63}$, dentre outros tantos temas que serão analisados ao longo do nosso trabalho, tais como o conceito de direito adquirido ${ }^{64}$, ato jurídico perfeito ${ }^{65}$, coisa julgada $^{66}$, expectativa de direito ${ }^{67}$ e faculdade jurídica ${ }^{68}$. Reproduzimos a seguir suas conclusões, o primeiro bloco delas de ordem constitucional e o segundo de natureza ordinária:

"1.No estabelecimento de uma dogmática do Direito Intertemporal, em matéria civil, à face de quanto foi examinado no Direito dos Povos Cultos, e, particularmente, no Direito Brasileiro, devem-se distinguir antes de mais nada, os seus fundamentos constitucionais, dos princípios de caráter ordinário.

2. O texto da Constituição vigente, no que respeita ao Direito Adquirido, se funda em mais de setecentos anos de doutrina Luso-Brasileira e nacional; e, quanto ao seu caráter fundamental, em século e meio de sedimentação doutrinária e arraigamento à consciência popular.

3. O princípio da Irretroatividade das Leis é, por natureza, de caráter constitucional. O mesmo se pode afirmar em relação ao do Respeito ao Direito Adquirido;

\footnotetext{
${ }^{57}$ FRANÇA, Rubens Limongi. op. cit., p. 308 e ss.

${ }^{58}$ Id. Ibid., p. 330 e ss.

${ }^{59}$ Id. Ibid., p. 349 e ss.

${ }^{60}$ Id. Ibid., p. 377 e ss.

${ }^{61}$ Id. Ibid., p. 405 e ss.

${ }^{62}$ Id. Ibid., p. 420 e ss.

${ }^{63}$ Id. Ibid., p. 461 e ss.

${ }^{64}$ Id. Ibid., p. 426 e ss e 432 e ss.

${ }^{65}$ Id. Ibid., p. 436 e ss.

${ }^{66}$ Id. Ibid., p. 439 e ss.

${ }^{67}$ Id. Ibid., p. 442 e ss.

${ }^{68}$ Id. Ibid., p. 446 e ss.
} 
4. De acôrdo com a Constituição, que, nesta matéria, atende perfeitamente aos imperativos das nossas tradições jurídicas e populares, os fundamentos dogmáticos da matéria, no plano fundamental, são os seguintes:

a) É de caráter constitucional o Princípio da Irretroatividade das Leis.

b) O mesmo se dá em relação ao Princípio do Respeito ao Direito Adquirido.

c) Êsses dois princípios obrigam aos legisladores.

d) Êsses dois princípios, com maior razão, obrigam aos Juízes.

e) A regra, no silêncio da lei, é a irretroatividade.

f) Pode haver, entretanto, retroatividade expressa, desde que não ofenda Direito Adquirido.

g) O efeito retroativo não requer palavras sacramentais.

h) O estabelecimento das lindes do Direito Adquirido compete ao legislador ordinário.

i) Por vontade do legislador, o respeito ao Ato Jurídico Perfeito e à Coisa Julgada, constitui matéria constitucional.

j) As leis interpretativas não retroagem: o que se dá é a aplicação da própria lei interpretada.

1) As leis aparentemente interpretativas constituem lei nova.

m) O Direito Adquirido, de acôrdo com uma interpretação desmentida pela lei interpretativa, deve ser em princípio respeitado.

n) Tal não prevalecerá se resultar de interpretação arbitrária.

5. A despeito de alicerçado em uma tradição que nos vem do fim do século passado (Projeto Coelho Rodrigues, 1893-1897) o texto da Constituição vigente não se compadece nem com a realidade da matéria, nem com a boa técnica constitucional.

6. Propomos a seguinte fórmula, para, de jure ferendo, figurar na nossa Lei Fundamental: 'A Lei dispõe para o futuro; ela não prejudicará o direito adquirido",69.

"1. A matéria concernente ao Direito Intertemporal, no sistema ordinário civil, funda-se primacialmente no art. $6^{\circ}$ da Lei de Introdução de 1942, com as modificações da lei n. 3.238, de 1957.

2. Êste diploma realizou a simbiose entre o art. $3^{\circ}$ da Lei de Introdução de 1916, vazado nos moldes da Doutrina Clássica, e o art. $6^{\circ}$

${ }^{69}$ FRANÇA, Rubens Limongi. op. cit., p. 539-540. 
originário da Lei de 1942, assentado sôbre a teoria de Roubier, na parte em que alude ao efeito imediato das leis.

3. Não obstante, e a despeito disso ter advindo da falta de melhores esclarecimentos dos nossos legisladores, não há incompatibilidade entre a substância da Doutrina Clássica e a idéia de efeito imediato. Essa virtude das novas leis, de se aplicarem imediatamente, entre nós, remonta às melhores e mais antigas tradições, e, no que tange às modernas formulações da Doutrina Clássica, é reconhecida por autores como Pacifici-Mazzoni.

4. O efeito geral das leis advém do seu caráter de commune praeceptum, e não interessa ao problema do Direito Intertemporal.

5. De acôrdo com a regra do efeito imediato, a nova lei não atinge os fatos anteriores, nem os efeitos anteriores dêsses fatos. Por outro lado, atinge os facta futura, bem assim as partes posteriores dos facta praeterita.

6. Não obstante, o limite do efeito imediato é o Direito Adquirido.

7. De acôrdo com a lei vigente, Direito Adquirido é aquêle que o titular possa exercer, conceito êsse que deve ser completado por elementos fornecidos pela Doutrina.

8. O conceito de Gabba, adotado pela generalidade de nossos autores, não é pròpriamente incompatível nem com a letra, nem com o espírito da nossa Lei. Não obstante, apresenta imperfeições que podem e devem ser sanadas.

9. No sentido de contribuir para êsse aperfeiçoamento, pedimos vênia para propor o seguinte conceito de Direito Adquirido: é a conseqüência de uma lei, por via direta ou por intermédio de fato idôneo; conseqüência que, tendo passado a integrar o patrimônio material ou moral do sujeito, não se fêz valer antes da vigência de lei nova sobre o mesmo objeto.

10. A referência ao Ato Jurídico Perfeito e à Coisa Julgada, que, repetindo e esmiuçando o preceito constitucional, faz o texto ordinário, é inútil històricamente, como à face da realidade jurídica.

11. O conceito de Direito Adquirido não se estende às Expectativas de Direito, isto é, às faculdades jurídicas abstratas ou em vias de se concretizarem, cuja perfeição está na dependência de um requisito legal ou de um fato aquisitivo específico.

12. Do problema das relações entre as Expectativas e as Faculdades Jurídicas e entre estas e o Direito Adquirido resulta o seguinte: a) as expectativas correspondem às faculdades abstratas, tanto dependentes de requisito como de fato aquisitivo específico; $b$ ) as faculdades concretas, isto é, aquelas que já passaram para o patrimônio material ou moral do sujeito, estão, tôdas elas, incluídas no conceito fundamental de Direito Adquirido; c) as faculdades de Direito Natural não se inserem no conceito de Direito Adquirido e não interessam à ciência do Conflito das Leis.

13. Os Direitos a têrmo se consideram adquiridos, seja a têrmo final ou inicial. 
14. Assim também os direitos sob condição. Com efeito, cumpre assinalar que: a) inexiste incompatibilidade entre a noção de Direito Adquirido e as relações condicionadas; b) não há contradição, nesta matéria, entre a Lei Preliminar e o corpo do Código (arts. 74, 118, 113, 953, 1.065).

15. São Adquiridos os direitos condicionados, tanto sob condição resolutiva como suspensiva.

16. A expressão 'inalterável a arbítrio de outrem’ é desnecessária, por isso que só se pode entender como alusiva às condições puramente potestativas.

17. Considera-se adquirido o direito sob condição mista, isto é, aquela constituída 'da vontade humana combinada a um fato casual'.

18. Há um êrro de perspectiva, da parte de certos autores, quando cuidam do problema dos fatos complexos. Uma vez que estamos tratando de Direito Adquirido, o que interessa não é a complexidade dos fatos senão da aquisição dos diversos direitos. Daí propormos que se fale, não em fatos complexos, mas em direitos de aquisição complexa.

19. Êsses direitos, a saber, os que decorrem da realização de vários elementos, variam em número de quatro: 1) os de aquisição imperfeita; 2) os de aquisição sucessiva; 3) os de aquisição por partes; e 4) os de aquisição plural.

20. Os de aquisição imperfeita são aquêles que se obtêm a têrmo ou sob condição. As conclusões respectivas concernentes ao Direito Intertemporal, já se encontram acima (itens 13 a 17).

21. Os direitos de aquisição sucessiva são aquêles que se conseguem mediante o decurso de um certo lapso de tempo. A êstes a lei nova se aplica imediatamente, isto é, considerando-se válido o lapso já decorrido, e computando-se o lapso por escoar, de acôrdo com a lei nova.

Nas hipóteses de encurtamento do prazo, deve-se estabelecer uma proporção entre o prazo anterior e o da lei nova.

22. Os direitos de aquisição por partes são aquêles que se auferem mediante a perfeição autônoma de vários elementos conexos.

Aplicando-lhes a lei nova imediatamente, ficam respeitadas as partes autônomas já realizadas de acôrdo com a lei antiga.

23. Os direitos de aquisição plural, isto é, aqueles que se incorporam ao nosso patrimônio em virtude de causas diversas de valor suficiente, são adquiridos de acôrdo com a lei do tempo da perfeição de cada fato aquisitivo" ${ }^{, 70}$.

Como se vê, Rubens Limongi França não só traça ensinamentos lapidares como também delineia um método próprio e brasileiro de resolução de conflitos de lei no tempo.

\footnotetext{
${ }^{70}$ FRANÇA, Rubens Limongi. op. cit., p. 541-544.
} 
Isto nos faz seguir de mãos dadas com o autor, que será lembrado em quase todas as passagens deste trabalho, na maioria das vezes para acatá-lo e em outras para - não por falta dele, mas por ousadia nossa - tentar trazer alguma contribuição à sua obra, que já aniversaria em quatro décadas.

De sua última edição até os dias de hoje, parece-nos que a matéria experimentou alguma evolução, não para fugir de suas raízes históricas mas para aprofundar a simbiose que há, no sistema de direito intertemporal brasileiro, entre as regras do efeito imediato e da proteção do direito adquirido.

A doutrina brasileira mais atual, ao que nos parece, tem buscado cada vez mais um conceito de retroatividade que se alie à regra do efeito imediato, mas sem se afastar da proteção do direito adquirido. Em nosso sentir, isto recomenda que reavivemos as lições do mestre Rubens Limongi França à luz desses novos lampejos, não deixando que o direito intertemporal brasileiro se distancie de seu maior e eterno Professor.

\subsection{O estado atual da matéria no direito estrangeiro}

Mais do que uma curiosidade jurídica - e daí o caráter não exaustivo do tópico -, esta exposição sobre o atual estado da matéria no direito estrangeiro tem como finalidade demonstrar que os países europeus possuem regras diversas das do sistema brasileiro de direito intertemporal, não podendo ser importadas, sem ressalvas, teorias predominantes no velho continente, como têm feito a doutrina e os tribunais.

\subsubsection{A Espanha e a teoria dos "níveis de retroatividade"}

A Constituição da Espanha adota a regra da não-retroatividade. Dispõe o artigo 9.3 da Constituição da Espanha:

"9.3. A Constituição garante (...) a irretroatividade das disposições sancionadoras não favoráveis ou restritivas de direitos individuais" ${ }^{\text {"71 }}$.

\footnotetext{
${ }^{71}$ VERDERA IZQUIERDO, Beatriz. La irretroactividad: problemática general. Madrid: Dykinson, 2006. p. 18. Tradução livre de "La Constitución garantiza [...], la irretroactividad de las disposiciones sancionadoras no favorables o restrictivas de derechos individuales".
} 
Também o artigo 25.1 da Constituição da Espanha traz disposição a respeito:

"25.1. Ninguém pode ser condenado ou sancionado por ações ou omissões que no momento em que foram produzidas não constituíam delito, falta ou infração administrativa, segundo a legislação vigente naquele momento" ${ }^{, 72}$.

É assente, na doutrina e na jurisprudência espanholas, que tais dispositivos não se aplicam a relações privadas. A esse respeito, comenta Manuel Medina de Lemus:

\begin{abstract}
“deve-se ter em conta que não se dá em termos absolutos a regra da irretroatividade. A Constituição estabelece-a somente para as disposições sancionadoras não favoráveis ou restritivas de direitos individuais. (...) não seria inconstitucional a retroatividade de outras disposições distintas das apontadas por ela, ${ }^{, 73}$.
\end{abstract}

No mesmo sentido é o entendimento do Tribunal Supremo da Espanha: "O artigo 9.3 da Constituição não proíbe a retroatividade geral das normas legais, senão exclusivamente daquelas que tenham caráter sancionador ou restritivo de direitos individuais, possibilitando o efeito retroativo das normas regulamentares" ${ }^{\text {74 }}$.

Também interessante é o comentário de Thiago Massao Cortizo Teraoka, ao transcorrer sobre o tratamento conferido ao princípio da irretroatividade pelos tribunais espanhóis:

\begin{abstract}
"Todavia, esse dispositivo não tem a mesma força no âmbito civil ou penal. O Tribunal Constitucional espanhol decidiu que 'a retroatividade das disposições sancionadoras não favoráveis e restritivas de direitos individuais (art. 9.3. CE) não é suscetível de ser alegada em recurso de amparo, pois esse princípio não tem natureza de direito fundamental, salvo em Direito Penal ou Direito Administrativo sancionador'.
\end{abstract}

\footnotetext{
${ }^{72}$ VERDERA IZQUIERDO, Beatriz. op. cit. Tradução livre de "Nadie puede ser condenado o sancionado por ocasiones $u$ omisiones que en el momento de producirse no constituyan delito, falta o infracción administrativa, según la legislación vigente en aquel momento".

${ }^{73}$ in MEDINA DE LEMUS, Manuel. Derecho civil: parte general. Madrid: Dilex, 2006. p. 123. Tradução livre de: "debe tenerse en cuenta que no se da en términos absolutos la regla de la irretroactividad. La Constitución la establece sólo para las disposiciones sancionadoras no favorables o restrictivas de derechos individuales. (...) no sería anticonstitucional la retroactividad de otras disposiciones distintas a las apuntadas en ella".

${ }^{74}$ STS 21 de abril de 2005 (RJA 3476). in VERDERA IZQUIERDO, Beatriz. op. cit., p. 25. Tradução livre de "El artículo 9.3 de la Constitución no prohíbe la retroactividad general de las normas legales, sino exclusivamente de aquélla que tiene un caráter sancionador o restrictivo de derechos individuales, posibilitando o efecto retroactivo de las normas reglamentarias".
} 
Em outro acórdão, decidiu o Tribunal Constitucional espanhol que a expressão 'restrição a direitos individuais', do artigo 9.3 da Constituição da Espanha, deve equiparar-se à idéia de sanção, ligada a direitos fundamentais e liberdades públicas. Nesse mesmo acórdão, o Tribunal Constitucional consagrou que a Constituição da Espanha vedaria apenas a retroatividade, a qual deverá ser 'entendida como incidência da nova lei sobre os efeitos jurídicos já produzidos de situações anteriores, de sorte que a incidência nos direitos, quanto a sua projeção para o futuro, não pertence ao estrito campo da irretroatividade'. Portanto, na Constituição espanhola não haveria vedação à retrospectividade legal e completa proteção aos direitos adquiridos"75.

Em nível infraconstitucional, o Código Civil espanhol dispõe que as leis só poderão ter efeito retroativo se dispuserem nesse sentido, expressa ou tacitamente - e, em uma análise sistemática, desde que não contrariem o texto do artigo 9.3 da Constituição. Este o texto do artigo 2.3 do Código Civil da Espanha:

"2.3. As leis não terão efeito retroativo, se não o dispuserem em contrário" ${ }^{\text {,76. }}$.

Nesse contexto, o direito intertemporal espanhol poderia ser assim sintetizado: (1) existe proibição constitucional à retroatividade das normas punitivas ou restritivas de direitos fundamentais, mas não à retroatividade das normas de outra natureza; (2) em nível infraconstitucional, existe a proibição ao efeito retroativo, salvo se expresso; e (3) não há previsão, constitucional ou legal, de proteção ao direito adquirido. Portanto, na Espanha, uma lei poderia, em tese, atingir direitos adquiridos e atos já consumados, salvo se tiver caráter punitivo ou restritivo de direitos individuais.

Contudo, para evitar insegurança jurídica, doutrina e jurisprudência espanholas buscaram amparo na teoria dos "níveis de retroatividade" - a qual, diga-se desde já, não se aplica ao sistema brasileiro, que proíbe a ofensa a direitos adquiridos sem vedar a retroatividade (seja ela mínima, média ou máxima). De acordo com esta teoria, o Legislador não teria poderes absolutos sobre os efeitos da lei nova, devendo estipulá-los dentro de uma certa margem. Para determinar qual seria esta "margem", a doutrina dividiu a retroatividade em mínima, média e máxima.

\footnotetext{
${ }^{75}$ in TERAOKA, Thiago Massao Cortizo. Poder Constituinte e direitos adquiridos. 2006. Dissertação (Mestrado) - Faculdade de Direito, Universidade de São Paulo, São Paulo, 1992. p. 111-112.

${ }^{76}$ in VERDERA IZQUIERDO, Beatriz. op. cit., p. 26. Tradução livre de "Las leyes no tendrán efecto retroactivo, si no dispusieren lo contrario"
} 
Ocorreria retroatividade mínima quando a lei nova atingisse efeitos decorrentes de fato passado mas que só vieram a se verificar depois de seu advento; a retroatividade média, por sua vez, dar-se-ia quando a lei nova atingisse as partes posteriores dos fatos pendentes, preservando os fatos passados e os efeitos anteriores ao seu advento; já a retroatividade máxima se verificaria quando a lei nova atingisse os fatos passados e os efeitos ocorridos antes do início de sua vigência.

Bem resume a questão a lição de José Luis Lacrus Berdejo e Outros:

"Tal efeito [retroativo] poderia ser entendido de muitas diferentes maneiras e, para explicar essa diversidade, é usual em nossa doutrina a distinção entre os 'níveis' de retroatividade. A retroatividade de grau máximo suporia privar de efeitos as relações jurídicas não só nascidas mas também consumadas ao entrar em vigor da lei nova. Este efeito retroativo forte ou pleno não é freqüente, nem em princípio, deve supô-lo o intérprete como consequiência da retroatividade tácita. A de grau médio respeita a relação nascida sob a lei antiga, mas sujeita à lei nova todos os efeitos pendentes. $\mathrm{Na}$ de grau mínimo, a lei nova só se aplica, no que toca às relações anteriores, aos efeitos que se produzam depois de sua entrada em vigor", ${ }^{37}$.

Como se vê, ao tratar de retroatividade mínima e média, a teoria dos "níveis de retroatividade" acaba por equiparar os efeitos retroativo médio e mínimo ao efeito imediato da lei nova. Não por outro motivo é que os tribunais espanhóis os admitem mesmo que tacitamente, pois o efeito imediato não está inserto na proibição contida no artigo 2.3 do Código Civil da Espanha - que pró́be apenas a retroatividade. Comenta Beatriz Verdera Izquierdo, partidária da teoria dos "níveis de retroatividade":

"Este tipo de retroatividade [retroatividade mínima] nos situaria no denominado 'efeito diferido', ou seja, a lei nova se aplicará a todas aquelas relações que se constituam no futuro. Sem afetar as conseqüências futuras das relações criadas na vigência da lei antiga, o que nos levaria à retroatividade de grau médio.

\footnotetext{
${ }^{77}$ in LACRUZ BERDEJO, José Luis; ASÍS SANCHO REBULLIDA, Francisco de; LUNA SERRANO, Agustín; DELGADO ECHEVERRÍA, Jesús; RIVERO HERNÁNDEZ, Francisco; RAMS LBESA, Joaquín. Elementos de derecho civil: parte general. 4. ed. rev. e atual. por Jesús Delgado Echeverría. Madrid: Dykinson, 2006. p. 212. v. 1. Tradução livre de "Tal efecto se podría entender de muy diversas maneras y, para explicar esta diversidad, es usual en nuestra doctrina la distinción de 'grados' de retroactividad. La retroactividad de grado máximo supondría privar de efectos a relaciones jurídicas no sólo nacidas sino consumadas ya al entrar en vigor la ley nueva. Este efecto retroactivo fuerte o pleno no es frecuente, ni, en principio, debe suponerlo el intérprete como consecuencia de retroactividad tácita. La de grado medio respeta la relación nacida bajo la ley antigua, pero la sujeta a la ley nueva para todos los efectos pendientes. En la de grado mínimo, la ley nueva sólo se aplica, respecto de relaciones anteriores, a los efectos que se produzcan después de su entrada en vigor".
} 
Esta retroatividade vem sendo admitida pelo Tribunal Supremo, ainda quando a disposição legal careça de mandato expresso neste sentido, quando assim se depreender do espírito e finalidade da norma. Basicamente devido a que a retroatividade em graus médio e mínimo não são consideradas como tal pelas doutrinas monistas, que admitem a existência de uma única retroatividade. Para estas, a retroatividade em tais níveis se trata de aplicação imediata da lei nova. A STS de 17 de maio de 2005 (RJA 5720) [decisão do Tribunal Supremo da Espanha], entre outras, estabelece que 'esta retroatividade de caráter mínimo é excluída pelo Tribunal Constitucional e pelo Tribunal Supremo da retroatividade em sentido próprio'. Tudo isso nos conduz de novo ao conceito de irretroatividade, e de acordo com a STS de 26 de janeiro de 1980 (RJA 277): '... em paridade com a doutrina, somente se pode falar em irretroatividade quando se submete à nova situação normativa direitos pertencentes definitivamente ao passado e, portanto, não existe aplicação retroativa quando se sujeitem à norma nova direitos pendentes no tempo..." ${ }^{78}$.

Já a retroatividade máxima, embora não vedada pela Constituição ou pelo Código Civil da Espanha, salvo nos casos já mencionados - de normas punitivas ou restritivas de direitos fundamentais -, não seria admitida pela doutrina em razão do respeito à segurança jurídica, lá assegurada constitucionalmente. A esse respeito, opina Beatriz Verdera Izquierdo que "esta retroatividade é de duvidosa constitucionalidade (...) certa a jurisprudência ao referir que os graus de retroatividade da Constituição não admitem a retroatividade em grau máximo por vulnerar a segurança jurídica"79.

A exposição desta teoria, denominada "níveis de retroatividade", demonstra que a sua adoção, na Espanha, serviu para resguardar a segurança jurídica nos casos em que a lei nova, expressa ou tacitamente, pudesse vir a atingir fatos consumados e efeitos anteriores ao início da vigência da lei nova (ao que se chamou de retroatividade máxima), apesar de, pelo que dispõem a Constituição e o Código Civil da Espanha, poder-se admitir tal possibilidade.

\footnotetext{
${ }^{78}$ in VERDERA IZQUIERDO, Beatriz. op. cit., p. 92. Tradução livre de "Este tipo de retroactividad, nos situaría ante el denominado 'efecto diferido', o sea la ley nueva se aplicará a todas aquellas relaciones que se constituyan en el futuro. Sin afectar a las consecuencias futuras de las relaciones creadas vigente da antigua ley, que nos llevaría a la retroactividad en grado medio.

Esta retroactividad ha venido siendo admitida por el Tribunal Supremo, aún cuando la disposición legal carezca de mandato expreso en tal sentido, cuando así deviene del espíritu o finalidad de la norma. Básicamente debido a que la retroactividad en grado medio y mínimo, no son consideradas como tales por las doctrinas monistas, que admiten la existencia de una única retroactividad en tales grados se trata de aplicación inmediata de la norma nueva. La STS de 17 de mayo de 2005 (RJA 5720) entre otras, establece que 'esta retroactividad de carácter mínimo es excluida por el Tribunal Constitucional y por el Tribunal Supremo de la retroactividad en sentido propio'. Todo ello nos conduce de nuevo al concepto de irretroactividad y de acuerdo con la STS de 26 de enero de 1980 (RJA 277): '... en puridad de doctrina, sólo puede hablarse de irretroactividad cuando se somete a la nueva situación normativa hechos pertenecientes definitivamente al pasado y, por tanto, no existe aplicación retroactiva cuando se sujeten a la norma nueva los hechos todavía subsistentes en ele tiempo...”.

${ }^{79}$ Id. Ibid., p. 89.
} 
Não faz o menor sentido a adoção dessa teoria no Brasil, pois (1) a não-proteção da retroatividade média e mínima acaba por vulnerar a proteção do direito adquirido, que entre nós é assegurada constitucionalmente; e (2) a equiparação do efeito imediato ao efeito retroativo médio e mínimo somente confunde, sugerindo uma vedação, em nosso sistema, ao efeito imediato da lei nova, que não só não é proibido como constitui a regra, encontrando limite apenas na proteção do direito adquirido, do ato jurídico perfeito e da coisa julgada. Por esta razão, não devemos importar a teoria dos níveis de retroatividade para os tribunais brasileiros, com tem ocorrido ${ }^{80}$.

\subsubsection{A Itália e a teoria dos "fatos consumados"}

A Constituição da Itália proíbe a retroatividade apenas no que toca à lei penal. Em nível infraconstitucional, contudo, dispõe o artigo 11 do Código Civil:

"11. Eficácia da lei no tempo: A lei não dispõe senão para o futuro: essa não possui efeito retroativo" $"$.

Na doutrina, a teoria que mais congregou adeptos na Itália foi a dos fatos consumados, sintetizada no brocardo tempus regit actum. A esse respeito, comenta Rolando Tarchi:

"A jurisprudência já está consolidada em um sentido bem delineado. Numerosas são, de fato, as sentenças que indicam os princípios-guia a serem utilizados na averiguação da eficácia temporal do ius superveniens (...).

A regra geral seguida, obviamente, quase sempre faz referência direta ao art. 11 (...), à necessária não-retroatividade da nova norma legislativa, no sentido de que, salvo contrária indicação expressamente formulada pelo legislador, esta pode regular apenas as relações jurídicas futuras, nunca as pregressas.

O princípio em questão é aquele da imediata aplicação da nova lei, já exposto e sintetizado na expressão breve "tempus regit factum", ${ }^{\text {", }}$.

\footnotetext{
${ }^{80}$ Por exemplo, ADIN n ${ }^{\circ} 492-0 / \mathrm{DF}$, que será comentada no item 4.2.1.

${ }^{81}$ in VERDERA IZQUIERDO, Beatriz. op. cit., p. 16. Tradução livre de "Efficacia della legge nel tempo: La legge non dispone che per l'avvenire: essa non ha effetto retroattivo".

${ }^{82}$ in TARCHI, Rolando. Le leggi di sanatoria nella teoria del diritto intertemporale. Milano: Giuffrè, 1990. p. 271-275.
} 
Tal forma de resolver conflitos de lei no tempo decorre do raciocínio de que os efeitos do fato jurídico "devem ser por êle abrangidos, devem ser havidos como nêle compreendidos, já existentes em consequiência do ato, escapando assim à fôrça obrigatória da lei nova, que para tais efeitos deve ser completamente estranha”, nas palavras de J.M. de Carvalho Santos ${ }^{83}$.

Conforme explica Beatriz Verdera Izquierdo, a teoria dos fatos consumados

"unicamente toma como referência o momento temporal em que se realiza o direito e, de acordo com o mesmo, determina se este cai no âmbito de vigência de uma ou outra lei. O princípio da irretroatividade se resolve pela máxima 'tempus regit actum' (...) irretroatividade significa que a lei nova não pode afetar os direitos já realizados na vigência da lei antiga" ${ }^{" 84}$.

Na lição de Francesco Messineo, a teoria dos fatos consumados está assentada na máxima de que

“o juiz não pode aplicar a nova norma a fatos passados (consumados). Tal aplicação o juiz faria (arbitrariamente) se desconhecesse as conseqüências já realizadas do fato passado, ou se tolhesse eficácia (ou atribuísse uma eficácia diferente) às consequiências daquele fato, quando tais consequiências se sucederam sob o império da norma nova; e somente porque o fato do qual dependem aquelas conseqüências não são conforme a norma nova”, ${ }^{\natural 5}$.

Em arremate, Maria Teresa Díaz Aznarte ensina que "a teoria dos fatos consumados se centra na máxima tempus regit factum, que em termos gerais significa que cada direito há de ser regulado pela lei sob o amparo da qual este nasceu" ${ }^{\text {" }}$.

\footnotetext{
${ }^{83}$ in SANTOS, J. M. de Carvalho. Código Civil brasileiro interpretado: introdução e parte geral. Rio de Janeiro: Freitas Bastos, 1943. v. 1, p. 46-47.

${ }^{84}$ in VERDERA IZQUIERDO, Beatriz. op. cit., p. 68. Tradução livre de "Únicamente toma como referencia el momento temporal en el que se realiza el hecho y, de acuerdo al mismo, determina si éste cae en el ámbito de vigencia de una u otra ley. El principio de irretroactividad se resuelve en la máxima 'tempus regit actum' (...) irretroactividad significa que la ley no puede afectar a hechos ya realizados vigente la antigua".

${ }^{85}$ in MESSINEO, Francesco. Manuale di diritto civile e commerciale. Milano: Giuffrè, 1957. p. 90.

${ }^{86}$ in DÍAZ AZNARTE, Maria Teresa. Teoría general de la sucessión de normas en el tiempo: una reflexión crítica sobre los principios ordenadores de la eficacia temporal de las leyes. Valência: Tirant lo Blanch, 2002. p. 77. Tradução livre de "la teoría del hecho jurídico realizado, se centra en la máxima tempus regit factum, que en términos generales significa que cada hecho jurídico ha de ser regulado por la ley al amparo de la cual nació".
} 
A nosso ver, a teoria não é totalmente compatível com o sistema brasileiro de direito intertemporal, que limita o efeito da lei nova apenas ao direito adquirido, admitindo que, não o ofendendo, atinja efeitos presentes de fatos passados.

\subsubsection{A França e o efeito imediato mitigado}

Em nível constitucional, a França disciplina apenas a não-retroatividade da lei penal. Dispõe o artigo $8^{\circ}$ da Declaração dos Direitos do Homem e do Cidadão, de 1789, incorporada à Constituição francesa de 1791: "Art. $8^{\circ}$. A lei apenas deve estabelecer penas estrita e evidentemente
necessárias e ninguém pode ser punido senão por força de uma lei
estabelecida e promulgada antes do delito e legalmente aplicada".

A não-retroatividade da lei civil está encartada em nível infraconstitucional. Dispõe o artigo $2^{\circ}$ do Código Civil de Napoleão:

“A lei não dispõe senão para o futuro; ela não possui efeito retroativo" ${ }^{\text {,87. }}$.

Diferentemente do que se dá na Itália e Espanha, os franceses solucionam os problemas de direito intertemporal pela noção de efeito imediato da lei nova. Influenciados por Paul Roubier, doutrina e jurisprudência partem do pressuposto de que a lei atua para dela em diante, atingindo os fatos presentes, futuros e pendentes. A lei nova incide sobre todas as

\footnotetext{
${ }^{87}$ Tradução livre de "2 ${ }^{\circ}$. La loi ne dispone que pour l'avenir; elle n'a point effet retroactif'. Tradução livre de “2 $2^{\circ}$. La loi ne dispone que pour l'avenir; elle n'a point effet retroactif'. Dispositivos parecidos encontramse em Portugal, artigo 12 do Código Civil ("a lei só dispõe para o futuro; ainda que lhe seja atribuída eficácia retroativa, presume-se que ficam ressalvados os efeitos já produzidos pelos factos que a lei se destina a regular"); Argentina, artigo $3^{\circ}$ do Código Civil ("a partir de sua entrada em vigor, as leis se aplicarão inclusive às consequiências das relações e situações jurídicas existentes. Não têm efeito retroativo, sejam ou não de ordem pública, salvo disposição em contrário. A retroatividade estabelecida por lei em nenhum caso poderá afetar direitos amparados por garantias constitucionais. Aos contratos em curso de execução não são aplicáveis as novas leis supletivas". Tradução livre de "a partir de su entrada en vigencia, las leyes se aplicarán aún a las consecuencias de las relaciones y situaciones jurídicas existentes. No tien5en efecto retroactivo, sean o no de orden público, salvo disposición en contrario. La retroactividad establecida por la ley en ningún caso podrá afectar derechos amparados por garantías constitucionales. A los contratos en curso de ejecución no son aplicables las nuevas leyes supletorias"); Venezuela, artigo $3^{\circ}$ do Código Civil ("a lei não tem efeito retroativo". Tradução livre de "La ley no tiene efecto retroactivo"); e Uruguai, artigo $7^{\circ}$ do Código Civil ("as leis não têm efeito retroativo". Tradução livre de "Las leyes no tienen efecto retroactivo").
} 
relações em curso, com exceção dos contratos, os quais continuam regulados por efeitos remanescentes da lei revogada.

Como informa Sylvain Mercoli, desde Paul Roubier até hoje a jurisprudência francesa segue tais orientações:

"Esse princípio do efeito imediato da lei é expressamente consagrado pela jurisprudência, tratando-se dos efeitos futuros das situações não contratuais. Entretanto, segundo a tradição individualista do século dezenove, o intérprete decide, no silêncio da lei, manter a lei antiga pelos contratos em curso. Isso vem preservar o contrato das mudanças legislativas posteriores à sua conclusão. Essa regra continua ainda hoje, a ser aquela que retém a Corte de Cassação. Ela se impõe ao juiz, que deve aplicá-la de ofício, mesmo quando as partes não a tenha invocado. Inseparável da influência da doutrina dos direitos adquiridos a solução quer ser, ela mesma, uma ilustração do princípio de não retroatividade da nova lei nos contratos em curso de execução" ${ }^{\text {88 }}$.

Este sistema é, talvez, o que mais se aproxima do direito intertemporal brasileiro, com a diferença de que, no Brasil, o efeito imediato da lei nova é obstado não somente no caso dos contratos, mas em qualquer hipótese de direito adquirido. Isto demonstra que, embora aparentemente antagônicas, as teorias do direito adquirido e das situações jurídicas convergem para uma mesma solução, que é a aplicação da lei nova, em regra, e a sobrevivência da lei revogada como exceção.

\footnotetext{
${ }^{88}$ in MERCOLI, Sylvain. La retroativité dans le droit des contracts. Marseille: Presses Universitaires D'aixMarseilleis, 2001. p. 314. Tradução livre de: "Ce principe de l'effet immédiat de la loi est expressémente consacré par la jurisprudence, s'agissant des effets futurs des situations non contractualles. Cepedant, selon la tradition individualist du dix-neuvième siècle, l'interprète décide, dans le silence de la loi, de maintenir la loi ancienne pour les contrats en cours. Cela revient à préserver le contrat des changements législatifs postérieurs à sas conclusion. Cette règle demeure, aujourd'hui encore, celle que retiente la Court de cassation. Elle s'impose au juge qui doit l'appliquer d'office, quand bien même les parties ne l'auraient pas invoquée. Inseparable de l'influence de la doctrine des droits acquis, la solution se veut ellemême une illustration du principe de non rétroactivité de la loi nouvelle sur les contrats en cours d'exécution".
} 


\section{SEGUNDA PARTE. PRINCÍPIOS E REGRAS DO DIREITO INTERTEMPORAL}

\subsection{O objeto do direito intertemporal}

O direito intertemporal é o conjunto de regras de solução de conflitos entre normas de igual objeto e hierarquia, decorrentes da sucessão das leis no tempo. Conforme ensina Nestor Duarte, "toda a questão pertinente ao direito intertemporal deve partir do pressuposto da alteração legislativa, sem o que a matéria carecerá de objeto" ${ }^{\text {}} 9$.

As regras de direito intertemporal não deverão ser aplicadas nos casos de sucessão não-conflitual. A intertemporalidade é não-conflitual quando a lei nova não tem exatamente o mesmo objeto da lei revogada. Por exemplo, o prazo de prescrição para as ações de reparação civil, do artigo 206, $\S 3^{\circ}$, inciso V, do Código Civil de 2002, não conflita com o estabelecido pelo artigo 177 do Código Civil de 1916, pois aquele é prazo especial enquanto este é prazo geral - não há perfeita identidade de objetos, razão pela qual não se pode falar em conflito. Logo, está-se diante de intertemporalidade não-conflitual, que não autoriza a utilização das regras de direito intertemporal, como por exemplo a contida no artigo 2.028 do Código Civil de 2002 (item 5.1.4).

Quando a sucessão de leis não gera conflito, a lei nova constitui direito novo, que tem aplicação imediata. De aparente pouca importância, tal ressalva ajudará a resolver problemas práticos de direito intertemporal, e.g. os tratados nos itens 5.1.4, 5.1.5 e 5.5.2.

As regras de direito intertemporal devem ser cogitadas apenas nos casos de intertemporalidade conflitual, ou seja, quando a sucessão de leis gerar conflito. Nas palavras de Caio Mário da Silva Pereira, "o conflito temporal de leis pode resumir-se numa indagação: Por qual das duas leis, a nova ou a velha, devem ser reguladas as conseqüências dos fatos ocorridos antes de entrar em vigor a lei revogadora? Noutros termos: A lei velha

\footnotetext{
${ }^{89}$ in DUARTE, Nestor. Direito intertemporal e prescrição no novo Código Civil. In: CIANCI, Mirna (Coord.). Prescrição no novo Código Civil: uma análise interdisciplinar. São Paulo: Saraiva, 2006. p. 347.
} 
deve continuar regulando as situações originadas durante sua vigência, ou a lei nova as alcança ao entrar em vigor?"90.

\subsection{Os fatos passados, presentes, futuros e pendentes}

Para que exista a idéia de movimento - do ordenamento inclusive -, é necessário considerar-se juridicamente a idéia de tempo - esta ilusão, como afirmou Einstein ${ }^{91}$. Não podendo experimentar a verdade do tema, a razão humana opera cortes no tempo cronológico, dividindo-o em "passado", "presente" e "futuro"; toma um referencial e, dentro de um único tempo, estabelece planos nos quais os fatos devem transitar.

Por serem naturalmente estáticas, as normas são tomadas como referencial "de corte". Os fatos serão passados, presentes e futuros conforme o sejam anteriores, concomitantes ou posteriores à lei nova. $\mathrm{O}$ fato pendente será o que nasce de uma determinada lei e continua a produzir efeitos na vigência de outra que a tenha revogado. Rubens Limongi França demonstra que esses conceitos aparecem na Segunda Regra Teodosiana, para a qual são "Facta futura os sucedidos ex die legis"; "Facta praeterita os sucedidos ante diem legis"; e "Facta pendentia os sucedidos ante diem legis, mas cujos efeitos ultrapassam a promulgação da lei nova" ${ }^{, 92}$.

Por exemplo: um contrato celebrado antes do início da vigência do Código Civil de 2002 será considerado fato passado; um contrato celebrado concomitantemente ao início de sua vigência será um fato presente; um contrato celebrado depois do início de sua vigência será um fato futuro; já uma relação iniciada na vigência do Código Civil de 1916, mas que tenha continuado a produzir efeitos mesmo depois do início de vigência do Código Civil de 2002, será considerada um fato pendente.

\footnotetext{
${ }^{90}$ in PEREIRA, Caio Mário da Silva. Instituições de direito civil. 12. ed. Rio de Janeiro: Forense, 1991. v. 1, p. 99. Faz-se apenas a ressalva, a ser detalhada adiante (item 2.3), de que a expressão "continuar regulando" não deve ser entendida como se a lei anterior tivesse continuado a viger mesmo depois do advento da lei nova.

${ }^{91}$ in OST, François. O tempo do direito. Tradução de Maria Fernanda Oliveira. Lisboa: Instituto Piaget, 1999. p. 27.

92“'É norma assentada a de que as leis e constituições dão forma aos negócios futuros e de que não atingem os fatos passados, a não ser que tenham feito referência expressa, quer ao passado, quer aos negócios pendentes" (in FRANÇA, Rubens Limongi. Direito intertemporal brasileiro: doutrina da irretroatividade das leis e do direito adquirido, cit., p. 68). Tal regra foi depois consolidada no direito canônico, quando a Constituição de Clemente V lhe adicionou a idéia de negotia praesentia (Id. Ibid., p. 94).
} 
Tal classificação permitirá distinguir os possíveis efeitos da lei. Haverá efeito retroativo quando a nova lei se voltar a fatos passados; imediato, quando atingir os fatos presentes e pendentes; diferido, quando alcançar somente os fatos futuros.

Já se analisada a questão sob a perspectiva da lei antiga, será possível compreender a ultratividade, em que o fato passado continua a ser regido por efeitos remanescentes da norma revogada, apesar do avento da lei nova. No citado exemplo, corresponderá à proteção dos efeitos pendentes de contrato celebrado antes do início de vigência do Código Civil de 2002, o que só se dará quando constituírem direito adquirido.

\subsection{Os possíveis efeitos da lei - considerações gerais}

Conforme já se adiantou, os conflitos de lei no tempo devem ser resolvidos pela conjugação das regras do efeito imediato e da proteção do direito adquirido, nesses termos: a lei "X", que revoga a lei "Y", deverá ser aplicada desde logo a todos os fatos pendentes, desde que não ofenda o direito adquirido, o ato jurídico perfeito e a coisa julgada. Tais figuras continuarão a ser regidas por efeitos da lei revogada, em razão da proteção constitucional e legal contida nos artigos $5^{\circ}$, inciso XXXVI, da Constituição Federal, e $6^{\circ}$, caput, da Lei de Introdução ao Código Civil.

Como se pode perceber, vigência e efeitos não se confundem. Poderá ocorrer de a lei ser vigente mas não projetar efeitos sobre um determinado fato, em razão da proteção do direito adquirido, do ato jurídico perfeito e da coisa julgada. Neste caso, os efeitos da lei revogada continuarão a reger uma determinada categoria de fatos, apesar do fim da vigência.

A vigência indica apenas aptidão para produzir efeitos, o que se dá após a votação, promulgação, publicação e o transcurso do período de vacatio legis ${ }^{93}$. Já os efeitos constituem a obrigatoriedade da norma vigente, o que se dá quando ela encontra fatos a que possa atribuir conseqüências. Como ensina Rolando Tarchi,

“(...) as duas expressões, vigência e obrigatoriedade, não podem ser consideradas sinônimas; a primeira indica uma condição objetiva que caracteriza a norma jurídica, que tem como referência o ordenamento

\footnotetext{
${ }^{93}$ A vacatio legis constitui "o intervalo entre a data da publicação da lei e de sua entrada em vigor." (in RODRIGUES, Silvio. Direito civil: parte geral. 32. ed. atual. de acordo com novo Código Civil (Lei n. 10.406, de 10-1-2002). São Paulo: Saraiva, 2002. v. 1, p. 17).
} 
jurídico, enquanto a segunda exprime um conceito de relação, que tem em conta não a norma jurídica em si mas o sujeito a que é destinada" ${ }^{94}$.

Em regra, a lei vigente obriga, incidindo sobre todos os fatos que objetiva regular, inclusive os pendentes. Contudo, a lei vigente não poderá projetar seus efeitos sobre o direito adquirido, o ato jurídico perfeito e a coisa julgada, caso em que será vigente mas não eficaz. Como observa Goffredo Telles Junior, “obrigatoriedade da lei tem restrições. De fato, ela é cerceada pelas três proibições mencionadas expressamente no citado art. $5^{\circ}$ da Constituição" 95 . Daí afirmar Rosa Maria de Andrade Nery, com razão, que "quando esbarra nesses bens tutelados pelo direito, a lei válida não produz efeitos" ${ }^{\text {"96 }}$.

Neste caso, tais fatos continuarão a ser regidos pelos efeitos remanescentes da lei antiga, muito embora revogada. Ou seja, os efeitos da lei revogada ultrapassarão seu marco final de vigência, atuando de maneira ultrativa - isto é, além do período de vigência. Não quer dizer que a lei antiga tenha continuado a viger, mas sim que os seus efeitos continuaram a reger uma determinada categoria de fatos, projetando-se para um tempo ulterior à sua revogação - como se disse, o que se dá em razão da proteção constitucional e legal contida nos artigos $5^{\circ}$, inciso XXXVI, da Constituição Federal, e $6^{\circ}$, caput, da Lei de Introdução ao Código Civil.

O fenômeno inverso também é possível. Como o tempo de vigência e os efeitos legais não necessariamente coincidem, a lei pode projetar efeitos sobre um fato ocorrido no passado. Neste caso, ocorrerá retroatividade da lei, o que é factível porque esta é uma proposição lógica do mundo do dever-ser, que pode, no presente, prever conseqüências a fatos ocorridos em momento diferente do de sua vigência. Não quer dizer que a lei tenha tido vigência no passado, mas apenas projetado efeitos para antes de entrar em vigor.

Como assevera Elival da Silva Ramos, os efeitos do ato legislativo

\footnotetext{
${ }^{94}$ TARCHI, Rolando. op. cit., p. 88. Tradução livre de “(...) le due espressioni di vigenza e di obbligatorietà non possono essere strettamente considerate come dei sinonimi; la prima sta infatti a dichiarare una condizione meramente oggettiva che caratterizza la norma giuridica, che ha come dato di referimento l'ordinamento giuridico nel suo complesso, mentre la senconda esprime un concetto di relazione, che tiente conto, oltre che della norma in sè, anche dei soggetti cui la stessa è destinata".

${ }^{95}$ in TELLES JUNIOR, Goffredo da Silva. Iniciação na ciência do direito. 3. ed. São Paulo: Saraiva, 2006. p. 197.

${ }^{96}$ in NERY, Rosa Maria de Andrade. Introdução ao pensamento jurídico e à teoria geral do direito privado. São Paulo: Ed. Revista dos Tribunais, 2008. p. 83.
} 
"podem perfeitamente projetar-se sobre realidades passadas, conformandoas, no presente, às suas exigências (...) os efeitos partem do presente para alcançar o passado, o que só é possível devido à circunstância de o sistema jurídico atuar em um plano ideal, ou seja, do dever-ser e não do ser"97.

Por fim, pode ocorrer de a lei projetar-se para o futuro, operando com efeitos diferidos. Contudo, estes não interessam ao direito intertemporal, pois não acarretam conflito de leis no tempo.

Em suma, o início de vigência e os efeitos da lei ocorrerão em regra no mesmo momento, ou seja, no presente (efeito imediato), mas poderá o Legislador dispor em contrário, estipulando que efeitos nascidos no presente rejam fatos ocorridos no passado (retroatividade) ou que só venham a se verificar no futuro (efeitos diferidos). Em qualquer caso, porém, o Juiz deverá garantir que os efeitos da lei revogada continuem a reger os direitos adquiridos sob o império da norma antiga, obstando os efeitos da lei nova (ultratividade).

\subsubsection{O efeito retroativo}

De há muito o poder de editar normas é utilizado como forma de desmandos, o que acabou associado ao efeito retroativo. Por isso, já as civilizações mais antigas buscavam formas de mitigar o poder legiferante, em especial quando atingisse os fatos passados ${ }^{98}$.

Como a retroatividade era e ainda é vedada em diversos sistemas, não foram poucas as tentativas de delinear seu alcance e significado, de forma a determinar aprioristicamente a norma aplicável em caso de conflito de leis. Duas são as principais teorias a respeito: (1) a lei seria retroativa quando atingisse fatos pendentes e direitos adquiridos, mesmo que atue só no presente, com efeito imediato; (2) a lei seria retroativa quando agisse sobre o passado, atingindo ou não direitos adquiridos.

Conforme referido nos itens 1.1 e 1.2.1, Carlos Francesco Gabba desenhou doutrina segundo a qual a lei que age sobre os fatos pendentes seria retroativa. $\mathrm{O}$ autor analisa a questão sob a perspectiva da lei revogada, classificando a novel como retroativa por atingir

\footnotetext{
${ }^{97}$ in RAMOS, Elival da Silva. A proteção aos direitos adquiridos no direito constitucional brasileiro. São Paulo: Saraiva, 2003. p. 13-14.

${ }^{98}$ in FRANÇA, Rubens Limongi. Direito intertemporal brasileiro: doutrina da irretroatividade das leis e do direito adquirido, cit., p. 21 e ss.
} 
fatos judicializados sob o império da norma antiga. Para tal doutrina, em regra a lei seria retroativa, apesar de atuar tão-só no presente, com efeito imediato.

Para esta corrente, a retroatividade seria permitida quando não ofendesse direitos adquiridos. Um de seus partidários, no Brasil, Reynaldo Porchat afirmava que a lei seria sempre retroativa - referindo-se à lei que age sobre fatos pendentes -, mas este efeito seria permitido quando não ofendesse direitos adquiridos ${ }^{99}$. Do contrário, a lei não poderia ser aplicada ao caso "porque a retroatividade seria injusta"100.

Deu-se que a ofensa a direitos adquiridos tornou-se sinônimo de retroatividade, o que é uma inverdade. Embora, em geral, os direitos adquiridos sejam atingidos não pelo efeito retroativo mas sim pelo efeito imediato da lei nova, a maior parte da doutrina acabou por tratá-los sinonimicamente, muito provavelmente como forma de estender aos fatos pendentes a mesma proteção que alguns ordenamentos conferem aos fatos passados.

Emidio Pacifici-Mazzoni, por exemplo, advertia que "esta expressão efeito retroativo não deve ser entendida literalmente, como se a lei atuasse hoje (...) no passado: com esta quer-se dizer que a nova lei se aplica imediatamente, isto é, no mesmo momento em que se tornar obrigatória" ${ }^{101}$. A conclusão é correta mas a premissa equivocada: se as expressões não são sinônimas, então não devem ser tratadas como se o fossem.

A equiparação indevida entre efeito retroativo e imediato foi motivada por uma questão utilitária: de maneira a proibir efeitos imediatos sobre os fatos pendentes - que constituem sem dúvida a maior fonte de insegurança jurídica -, parte da doutrina passou a denominá-los “efeito retroativo", enquadrando-os, assim, na vedação de sistemas que o proíbem ${ }^{102}$.

Por sua vez, Paul Roubier delineou teoria segundo a qual haveria efeito retroativo quando a lei nova atingisse os fatos passados e as partes anteriores dos fatos pendentes

\footnotetext{
${ }^{99}$ in PORCHAT, Reynaldo. op. cit., p. 6.

${ }^{100}$ Id. Ibid., p. 7.

${ }^{101}$ in PACIFICI-MAZZONI, Emidio. Istituzioni di diritto civile italiano. 5. ed. Torino: Unione TipograficoEditrice Torinese, 1929. v. 1, p. 120-121. Tradução livre de "questa espressione effetto retroattivo, non deve intèndersi letteralmente, quasi che la legge attuata oggi (...) al passato: con esta vuol dirsi che la nuova legge si applica immediatamente, cioé, nel momento stesso de divenire obbligatoria".

${ }^{102}$ Como afirma Pontes de Miranda, "a história do direito intertemporal é estrada sinuosa de experiências políticas, que alcança o cume na Revolução francesa e nos anos seguintes. Através dela corre rio tênue de preocupação científica, aqui e ali sacrificado pelos revolucionários extremados e pelos reacionários" (in MIRANDA, Francisco Cavalcanti Pontes de. Comentários à Constituição de 1946. 2. ed. São Paulo, Max Limonad, 1953. v. 4, p. 88).
} 
(itens 1.1 e 1.2.2). O autor analisa a questão sob a perspectiva da norma nova, que só seria retroativa se voltasse seus efeitos a período anterior ao seu advento. Com razão o autor.

Quando a lei nova atinge os fatos pendentes, mas não os passados, ela opera apenas com efeito imediato, e não retroativo. A esse respeito, pertinente a observação de Celso Antônio Bandeira de Mello:

\begin{abstract}
"não se pode dizer que sejam retroativas [as leis que agem no presente, de forma imediata, atingindo efeitos de fatos nascidos no passado], pois respeitam os efeitos que precederam a seu advento, alcançando tão-só aqueles efeitos que se estão propagando ainda e que, por isso mesmo, se desenrolam já à época da vigência da lei nova.

(...) retroagir é agir em relação ao passado. Se uma lei apanha relações que existem no presente, não está se reclinando sobre o pretérito; pelo contrário, está incidindo sobre aquilo que se processa na atualidade"103.
\end{abstract}

Como afirmava Vicente Ráo, "retroatividade e efeitos imediatos da nova norma obrigatória são conceitos (...) que não se confundem: enquanto aquela age sobre o passado, estes tendem a disciplinar o presente e o futuro" ${ }^{104}$. No mesmo sentido é a lição de Rubens Limongi França, de que "em princípio, além de não retroagir, o efeito da lei nova é imediato, isto é, ao mesmo passo que não atinge os fatos anteriores, nem mesmo os efeitos anteriores dêsses fatos, atua no mesmo momento em que se torna obrigatória"105.

Só existe retroatividade quando a lei age sobre fatos anteriores ao seu advento, ou seja, quando alterar conseqüência já produzida de acordo com hipótese da lei anterior. No entanto, haverá efeito imediato se a nova lei dispuser conseqüência diversa apenas para depois do início de sua vigência. Como ensina Valeria Mastroiacovo,

"A eficácia para o passado de um ato legislativo é, portanto, o resultado de um poder de repensar (...) uma fattispecie jurídica de um modo diverso

\footnotetext{
${ }^{103}$ in MELLO, Celso Antonio Bandeira de. O direito adquirido e o direito administrativo. Interesse Público, Porto Alegre, v. 8, n. 38, p. 18, 2006.

${ }^{104}$ in RÁO, Vicente. $O$ direito e a vida dos direitos. 6. ed. anotada e atualizada com o novo Código Civil por Ovídio Rocha Barros Sandoval. São Paulo: Ed. Revista dos Tribunais, 2005. p. 403.

${ }^{105}$ in FRANÇA, Rubens Limongi. Direito intertemporal brasileiro: doutrina da irretroatividade das leis e do direito adquirido, cit., p. 503.
} 
do que era anteriormente disciplinada, ou de atribuir uma relevância jurídica a algo que até então não tinha significado para o direito (...)"106.

Assim, por exemplo, será retroativa a norma que reduzir de cinco para dois por cento os juros bancários já percebidos. Por outro lado, não será retroativa a norma que diminuir ou aumentar o percentual de juros contratuais a partir do início de sua vigência. Neste caso haverá apenas efeito imediato da lei, que deverá ser obstado apenas se se verificar ofensa a direito adquirido.

Como se vê, o efeito retroativo não se confunde com as noções de direito adquirido e de efeito imediato. A lei nova poderá ter efeito retroativo sem ferir direitos adquiridos ou feri-los apenas com efeito imediato.

\subsubsection{O efeito imediato}

A idéia de efeito imediato surge ainda no direito visigótico. Como ensina Rubens Limongi França, "o Codificador de Toledo (...) se pode considerar um precursor da teoria do efeito imediato, modernamente articulada pela Doutrina, e de grande utilidade para a solução de certos problemas de Direito Intertemporal"107.

Depois, o Fuero de Cuenca ${ }^{108}$ vem receber do mestre a afirmação de que "o modo como está redigida a ordenação - De tempore quo dominus auferat pastores oves - de inequívoca correspondência com o texto primordial, parece trazer o mandamento de que a sua regra se aplica desde logo às situações em curso"109.

Tais manifestações foram influenciar a formação do direito luso, que, de acordo com Rubens Limongi França, "surgiu sob a égide da Doutrina do Efeito Imediato, que, a nosso

\footnotetext{
${ }^{106}$ in MASTROIACOVO, Valeria. I limiti alla retroattività nel diritto tributario. Milano: Giuffrè, 2005. p. 61. Tradução livre de: “'L'efficacia per il passato di un atto legislativo è, dunque, il risultato di un potere di ripensare (...) una fattispecie giuridica in modo diverso da come era precedentemente disciplinata o di attribuire una rilevanza giuridica ad un assetto fino ad allora non significativo per il diritto (...)."

${ }^{107}$ in FRANÇA, Rubens Limongi. Direito intertemporal brasileiro: doutrina da irretroatividade das leis e do direito adquirido, cit., p. 81. Ao aludir ao "Codificador de Toledo", o autor quer se referir a Flávio Rescinvindo, que em 671 d.C. promulgou a Lex Wisigothorum, unificando os estatutos romano e godo.

${ }^{108}$ Código Ibérico primitivo.

${ }^{109}$ Id. Ibid., p. 85.
} 
ver, constitui a nota marcante do Sistema Visigótico, à face do Direito Justinianeu"110 . O sistema português, por sua vez, acabou por informar o direito intertemporal brasileiro.

É da nossa tradição, portanto, a regra do efeito imediato. É para muitos algo de ordem natural, como ilustra Antônio Chaves ao afirmar que "da mesma forma que a talagarça só pode ser bordada à medida que a urdideira vai atirando as suas lançadeiras, assim também a lei só pode dispor para os atos que se desenrolam, isto é, para o presente e para o futuro: não é lógico que alcance o passado"111.

Como prevê o artigo $6^{\circ}$ da Lei de Introdução ao Código Civil, os efeitos da lei, após entrar em vigor, irão recair sobre os fatos vindouros, atuando sobre estes e com relação às consequiências presentes dos fatos passados. Haverá efeito imediato, pois, quando a nova norma agir para dela em diante, inclusive quanto aos fatos pendentes. Como afirma José Eduardo Martins Cardoso, "efeito imediato da lei é aquele que atinge fatos e situações no exato momento jurídico-temporal em que entra em vigor, não importando juridicamente se tais fatos ou situações remontam ou não no seu nascimento a um antigo diploma legislativo por esta nova lei substituído"112.

Desmembrando-se a norma em "hipótese" e "conseqüência", poder-se-á dizer que determinada lei opera apenas com efeito imediato quando "aplicável aos pressupostos que forem ocorrendo ou se completarem enquanto estiver em vigor, assim determinando as conseqüências jurídicas a serem produzidas (e que constituem a respectiva estatuição)", no dizer de Fernando Noronha ${ }^{113}$.

\footnotetext{
${ }^{110}$ FRANÇA, Rubens Limongi. Direito intertemporal brasileiro: doutrina da irretroatividade das leis e do direito adquirido, cit., p. 81. p. 255.

${ }^{111}$ in CHAVES, Antônio. Lições de direito civil: introdução à ciência do direito e parte geral do Código Civil. 2. ed. São Paulo: Ed. Revista dos Tribunais, 1978. p. 75-76.

${ }^{112}$ in CARDOSO, José Eduardo Martins. A retroatividade e a lei de introdução ao Código Civil. 1992. Dissertação (Mestrado) - Faculdade de Direito, Pontifícia Universidade Católica de São Paulo, São Paulo, 1992. p. 539.

${ }^{113}$ in NORONHA, Fernando. Retroatividade, eficácia imediata e pós-atividade das leis: sua caracterização correta, como indispensável para solução dos problemas de direito intertemporal. Cadernos de Direito Constitucional e Ciência Política, São Paulo, v. 6, n. 23, p. 95, abr./jun. 1998. Em texto posterior, no entanto (Id. Indispensável reequacionamento das questões fundamentais de direito intertemporal. Revista dos Tribunais, São Paulo, v. 94, n. 837, p. 60 e ss., jul. 2005), o autor vislumbra uma quarta categoria de efeitos da lei, que nomeia de "retrospectividade". Este efeito ocorreria quando o efeito imediato da lei atingisse os fatos pendentes.
} 
Como afirma Rubens Limongi França, "de acôrdo com a regra do efeito imediato, a nova lei não atinge os fatos anteriores, nem os efeitos anteriores dêsses fatos. Por outro lado, atinge os facta futura, bem assim as partes posteriores dos facta praeterita" ${ }^{\text {114 }}$.

Esse efeito poderá ser de duas ordens, conforme a categoria de fatos que venha a atingir. O primeiro, e mais comum, será o imediato simples ${ }^{115}$, isto é, aquele que vai reger apenas os fatos posteriores ao início da vigência da norma. É efeito que, para Elival da Silva Ramos, se ajusta “à perfeição, à sua vocação natural, que é a de reger todas as situações fáticas que se concretizem ao longo de seu período de vigência, sem dele desbordar, quer em direção ao passado, quer em direção ao futuro" ${ }^{\prime 16}$.

Por outro lado, o efeito imediato poderá também atingir efeitos pendentes de fatos passados. Neste caso, embora a lei nova vá reger apenas do presente para o futuro - razão por que não há de ser considerada "retroativa", conforme já se expôs -, atingirá efeitos de fatos nascidos no passado, constituindo um efeito imediato qualificado.

É o caso, por exemplo, de dispositivo transitório a prever que "os seus efeitos, produzidos após a vigência deste Código, aos preceitos dele se subordinam, salvo se houver sido prevista pelas partes determinada forma de execução" (artigo 2.035, caput, segunda parte, do Código Civil). Neste caso, a nova lei será aplicada aos efeitos presentes dos contratos entabulados antes do início de sua vigência.

Observa Elival da Silva Ramos que

"está-se aqui diante de um fenômeno dotado de tipicidade inequívoca, de um lado, inconfundível com a retroatividade e, de outro, embora inserido nos lindes da eficácia ordinária, imediata e prospectiva, do ato legislativo, ostentando traços próprios, não encontráveis nas demais hipóteses de efeitos instantâneos e para o futuro" $" 17$.

\footnotetext{
${ }^{114}$ in FRANÇA, Rubens Limongi. Direito intertemporal brasileiro: doutrina da irretroatividade das leis e do direito adquirido, cit., p. 541.

${ }^{115}$ Este efeito tem sido chamado de "prospectivo" pela maioria dos autores. Contudo, preferir-se-á a expressão "imediato simples", para que fique claro não se tratar de uma particular categoria eficacial, mas tão-somente uma das facetas possíveis do efeito imediato. Esta a mesma razão por que denominamos o efeito "retrospectivo" de imediato qualificado, conforme explicaremos adiante.

${ }^{116}$ in RAMOS, Elival da Silva. op. cit., p. 33.

${ }^{117}$ in Id. Ibid., p. 38.
} 
Tal peculiaridade levou autores modernos a tratarem o fenômeno de forma particularizada, vindo a falar não só em efeito imediato mas também em efeito "prospectivo" (efeito imediato simples) e "retroprospectivo"118 (efeito imediato qualificado). Fernando Noronha, por exemplo, afirma que "cada lei deverá ser aplicável aos fatos novos que acontecerem no seu tempo (prospectividade) e em princípio será também ela que deverá reger os efeitos que sejam produzidos no seu tempo por situações vindas do tempo anterior (retrospectividade) ${ }^{, 119}$.

Contudo, apesar de realmente merecerem atenção específica, não nos parece apropriado tratar "prospectividade" e "retroprospectividade" como categorias eficaciais específicas. Conforme aqui se demonstra, ambas são facetas de um único efeito ${ }^{120}$, e deverão ser tratadas como subdivisões desta única espécie - efeito imediato -, aqui denominadas, para fins meramente didáticos, imediato simples e imediato qualificado.

Este último constitui grande fonte de preocupação do direito intertemporal, pois, ao atingir os fatos pendentes, afigura-se a potencial maior fonte de conflitos de leis no tempo. Como se demonstrará, seu limite será a proteção do direito adquirido, a garantir que determinados fatos passados continuem a ser regidos pelos efeitos ultrativos de lei já revogada.

\subsubsection{Ultratividade dos efeitos da lei revogada}

Há casos em que, apesar do advento da lei nova, certos direitos continuam a ser regidos por efeitos da lei revogada. A isto se chama ultratividade, a qual pode se dar por disposição expressa da lei ou em razão da proteção do direito adquirido.

Quando a ultratividade se dá por disposição da lei nova, denominamo-la ultratividade propriamente dita. É o caso, por exemplo, do artigo $79, \S 1^{\circ}$, da Lei $n^{\circ} 8.906 / 94$, que dispõe sobre o Estatuto da $\mathrm{OAB}$, o qual estabelece que "aos servidores da $\mathrm{OAB}$, sujeitos ao regime

\footnotetext{
${ }^{118}$ Expressão que, segundo Elival da Silva Ramos, teria nascido no direito alemão, conforme expõe à página 38 de sua obra.

${ }^{119}$ in NORONHA, Fernando. Indispensável reequacionamento das questões fundamentais de direito intertemporal, cit., p. 61.

${ }^{120}$ Fato anotado, por exemplo, por Elival da Silva Ramos, que tece a seguinte consideração: "existe uma situação de pendência (eficacial e não fática) e, enquanto desdobramento no presente das conseqüências jurídicas de fato ocorrido no passado, existem aspectos fáticos desenvolvidos ao longo do período de vigência da lei nova; mas, ao contrário do que sucede nas hipóteses comuns de eficácia imediata e prospectiva, o fato-base dos efeitos jurídicos se realiza inteiramente no passado, isto é, durante a vigência da lei revogada". No entanto, também prefere utilizar a mesma divisão proposta por Fernando Noronha.
} 
da Lei no 8.112, de 11 de dezembro de 1990, é concedido o direito de opção pelo regime trabalhista". Quer dizer: embora tal lei devesse se aplicar, de maneira imediata, a todo e qualquer servidor, confere-se a alguns deles a possibilidade de optarem pelo regime da norma anterior, conferindo ultratividade aos efeitos desta.

Outro exemplo: o Código Civil de 2002 estabelece que, para gravar os bens da legítima com cláusula de inalienabilidade, impenhorabilidade e incomunicabilidade, o testador deve apresentar "justa causa" (artigo 1.848, caput). Como a lei tem efeito imediato, tal regra deveria se impor a todas as sucessões, mas o Código Civil de 2002 previu que a restrição só se aplicaria às sucessões abertas depois de um ano do início de sua vigência, ainda que o testamento tenha sido confeccionado na vigência do Código Civil de 1916. Durante este prazo, haverá ultratividade do Código Civil de 1916, podendo o testador aditar o testamento (item 5.7.3.3).

Por outro lado, a ultratividade também poderá ocorrer em razão da proteção do direito adquirido, o que é chamado por alguns autores de "pós-atividade"121 . Nesse caso, embora a lei nova vá se aplicar imediatamente - fazendo cessar de pronto a vigência da norma anterior -, os direitos adquiridos continuarão a ser regidos por efeitos remanescentes desta, em atenção à proteção contida no artigo $5^{\circ}$, inciso XXXVI, da Constituição Federal. A norma antiga deixou de viger, mas os seus efeitos continuaram a reger uma determinada categoria de fatos, projetando-se para tempo ulterior à sua revogação.

Na oportuna lição de Carlos Maximiliano, "a lei aplica-se imediatamente. A regra, para o juiz, é fazer observar o Direito vigente, salvo nos casos em que o Direito revogado conserva uma certa ultra-atividade" ${ }^{, 122}$.

O fenômeno fica claro em exemplo de Rubens Limongi França:

"suponhamos a hipótese clássica de uma nova lei sôbre determinado
contrato. A despeito do efeito imediato, a atuação das leis encontra limite no
Direito Adquirido. Ora, os contratos geram consequiências que, tendo entrado

\footnotetext{
${ }^{121}$ in NORONHA, Fernando. Retroatividade, eficácia imediata e pós-atividade das leis: sua caracterização correta, como indispensável para solução dos problemas de direito intertemporal, cit., p. 95. Preferimos ultratividade, para não dar a entender que a lei tenha continuado a viger depois de sua revogação. O que ocorre, apenas, é a projeção de seus efeitos para um tempo ulterior ao período de sua vigência, conforme discorremos no item 2.3.

${ }^{122}$ in MAXIMILIANO, Carlos. Direito intertemporal ou teoria da retroatividade das leis. 2. ed. Rio de Janeiro: Freitas Bastos, 1955. p. 20.
} 
para o patrimônio do sujeito, se caracterizam como tal. Ergo, a lei aplicável aos contratos é a antiga e não a nova" ${ }^{123}$.

Tomando-se novamente o caso do dispositivo transitório que prevê que "os seus efeitos, produzidos após a vigência deste Código, aos preceitos dele se subordinam" (artigo 2.035, caput, início da parte segunda, do Código Civil), tem-se que tal só se dará se não ocorrer ofensa a direito adquirido, e daí a ressalva "salvo se houver sido prevista pelas partes determinada forma de execução" (artigo 2.035, caput, final da parte segunda, do Código Civil).

Ocorre aí o que Celso Antônio Bandeira de Mello denominou de "blindagem”: “o direito adquirido é uma blindagem. É o encasulamento de um direito que segue e sempre seguirá envolucrado pela lei do tempo de sua constituição, de tal sorte que estará, a qualquer época, protegido por aquela mesma lei e por isso mesmo infenso a novas disposições legais que poderiam afetá-lo"124. Havendo tal blindagem, o fato continuará sendo regido pelos efeitos ulteriores da norma revogada.

\subsection{O princípio da irretroatividade}

O princípio da irretroatividade significa muito mais do que "não-retroatividade"125. Apesar da denominação, o princípio da irretroatividade não tem como finalidade obstar a retroatividade, mas sim garantir proteção ao direito adquirido, conferindo ultratividade aos efeitos da lei revogada.

O princípio da irretroatividade irá informar não só a não-retroatividade, mas também e principalmente os limites do efeito imediato, garantindo proteção não só a fatos e efeitos passados mas aos efeitos pendentes desses mesmos fatos.

\footnotetext{
${ }^{123}$ FRANÇA, Rubens Limongi. Direito intertemporal brasileiro: doutrina da irretroatividade das leis e do direito adquirido, cit., p. 510.

${ }^{124}$ in MELLO, Celso Antonio Bandeira de. op. cit., p. 19.

${ }^{125}$ Terá tal significado naqueles sistemas que vedam a retroatividade, o que não ocorre no sistema de direito intertemporal brasileiro. Entre nós, aplicar o princípio da irretroatividade não significa impedir a retroatividade, mas, sim, garantir que a lei antiga continue a reger um determinado fato. Terá portanto uma significação muito maior do que teria em sistemas estrangeiros, pois no direito intertemporal brasileiro o princípio da irretroatividade irá obstar não apenas o efeito retroativo mas também e principalmente o efeito imediato qualificado, qual seja, o efeito imediato que atinge os efeitos presentes dos fatos passados.
} 
Tal se dá, conforme se viu, pela proteção do direito adquirido, permitindo dizer que o princípio da irretroatividade se materializa na proteção deste. Esta conclusão tem respaldo na lição de Rubens Limongi França, para quem "dúvida inexiste de que, o princípio em foco, através dos tempos e dos povos, efetivamente, evolveu no sentido de amadurecer a idéia de que, em suma, o que se visa é impedir que as leis novas atinjam o Direito Adquirido nos têrmos das leis que se tenham revogado" ${ }^{\prime 126}$.

Em outras palavras, a irretroatividade é princípio que orienta a manutenção de certos efeitos da lei revogada, pela proteção do direito adquirido.

Não se deve dizer, pois, que determinada norma é "irretroativa", pois a irretroatividade é princípio de Direito e não efeito de lei. Como se demonstrou, os efeitos possíveis da lei nova são o retroativo, o imediato e o diferido, não o "irretroativo". Não se sustenta, pois, a dicotomia retroatividade versus irretroatividade. Informando a proteção do direito adquirido, esta limita todos os possíveis efeitos da lei, e não somente o retroativo ${ }^{127}$.

Portanto, o intérprete não deverá resolver conflitos de direito intertemporal pela fórmula “aplica-se a lei X porque Y é retroativa". Como o princípio da irretroatividade garante não a não-retroatividade, mas sim a ultratividade dos efeitos da lei revogada, a indagação a ser feita é se, imediata ou retroativamente, $\mathrm{Y}$ atinge direitos adquiridos, caso em que deverá escolher a lei X.

\subsection{O direito intertemporal no sistema brasileiro}

Rubens Limongi França observa que, a partir das Ordenações Manoelinas, o direito português - que depois informaria o direito intertemporal brasileiro - passa a conviver com a regra do efeito imediato. A seu ver, "parece que a regra fundamental é a validade das novas

\footnotetext{
${ }^{126}$ in FRANÇA, Rubens Limongi. Direito intertemporal brasileiro: doutrina da irretroatividade das leis e do direito adquirido, cit., p. 399. Daí por que afirma que "o Princípio da Irretroatividade das Leis, através dos séculos, evoluiu no sentido de se tornar mais preciso e definido, transmudando-se em Princípio do Respeito ao Direito Adquirido". Id. Ibid., p. 397.

${ }^{127}$ Quando se diz que a Constituição Federal não agasalhou o princípio da irretroatividade, incorre-se no equívoco de confundir "irretroatividade" com "não-retroatividade". Como se demonstrou, a "nãoretroatividade" é a negação de um dos possíveis efeitos da lei (o retroativo), enquanto a "irretroatividade" é princípio que vai informar os limites de todos os possíveis efeitos da lei - inclusive o imediato. Considerando-se que isto se dará pelo respeito ao direito adquirido, e levando-se em conta que a Constituição Federal expressamente o protege (artigo $5^{\circ}$, inciso XXXVI), é de se concluir que o sistema constitucional adotou, sim, o princípio da irretroatividade, se tomado em seu sentido apropriado.
} 
disposições post legem rogatam, conforme ressuma do constante emprego de verbos no subjuntivo futuro, bem assim do uso da expressão 'daqui em diante'",128.

Mas isto não levou o direito brasileiro para longe da proteção do direito adquirido ao contrário. Como ensina Rubens Limongi França, "a Constituição [de 1967] não estabeleceu nenhum preceito, expresso ou implícito, incompatível com a regra em aprêço. Disse apenas que a lei não prejudicará o direito adquirido, mas não esclareceu qual a natureza de seu efeito" ${ }^{\prime 29}$.

O direito intertemporal brasileiro acabou adotando um sistema misto, que observa tanto a regra do efeito imediato - propugnado pela teoria das situações jurídicas - quanto a proteção dos direitos adquiridos - usualmente atribuída à teoria do direito adquirido. Como se vem dizendo, isto não só não gerou incompatibilidade como deu coerência ao sistema, que atribuiu ao direito adquirido a tarefa de limitar o efeito imediato, garantindo ultratividade aos efeitos da norma revogada.

Com isto, o direito intertemporal brasileiro assumiu características próprias, o que recomenda não se importar esta ou aquela regra nem se adotar posicionamentos calcados em noção equivocada do efeito retroativo, que o nosso sistema não elege nem proíbe.

No Brasil, o intérprete não deverá resolver conflitos de direito intertemporal pela fórmula "aplica-se a lei X porque Y é retroativa". Como o princípio da irretroatividade garante não a não-retroatividade, mas, sim, a manutenção de efeitos da lei revogada, a indagação a ser feita é se, imediata ou retroativamente, $\mathrm{Y}$ atinge direitos adquiridos, caso em que deverá aplicar a lei X.

\subsubsection{O direito intertemporal nas Constituições Federais de 1824, 1891, 1934, 1937, 1946, 1967 e 1988}

Afora as trilhas por que passou em períodos anteriores à codificação, o direito intertemporal brasileiro caminhou por 6 Constituições até chegar ao artigo $5^{\circ}$, inciso XXXVI, da Constituição Federal de 1988.

\footnotetext{
${ }^{128}$ in FRANÇA, Rubens Limongi. Direito intertemporal brasileiro: doutrina da irretroatividade das leis e do direito adquirido, cit., p. 265.

${ }^{129}$ Id. Ibid., p. 421.
} 
A Constituição Federal do Império, de 1824, conferiu caráter constitucional ao princípio da irretroatividade, vedando não apenas a ofensa a "direitos adquiridos" mas também a retroatividade das leis. Confira-se:

"CF/1824: Art. 179. A inviolabilidade dos direitos civis e políticos dos cidadãos brasileiros, que têm por base a liberdade, a segurança individual e a propriedade, é garantida pela Constituição do Império, pela maneira seguinte:

I. Nenhum cidadão pode ser obrigado a fazer, ou deixar de fazer alguma cousa, senão em virtude de lei;

II. Nenhuma lei será estabelecida sem utilidade pública;

III. A sua disposição não terá efeito retroactivo"

A primeira Constituição Federal da República, de 1891, não mudou o tratamento dado à matéria, dispondo:

“CF/1891: Art. 11. É vedado aos Estados como à União:

$(\ldots)$

IV. Prescrever leis retroativas"

Consolidando a idéia de que o princípio da irretroatividade é informado pela proteção do direito adquirido - impedindo a aplicação da lei naqueles especiais casos em que a segurança jurídica dependesse da ultratividade dos efeitos da lei revogada -, a Constituição Federal de 1934 veio dispor:

“CF/1934: Art. 113. A Constituição assegura a brasileiros e a estrangeiros residentes no país a inviolabilidade dos direitos concernentes à liberdade, à subsistência, à segurança individual e à propriedade, nos termos seguintes:

(...)

3) A lei não prejudicará o direito adquirido, o acto jurídico perfeito e a coisa julgada" 
Por sua vez, inspirada pelo ideal totalitário do Estado Novo, a Constituição Federal de 1937 não trouxe dispositivo protegendo o direito adquirido, protagonizando o período obscuro do direito intertemporal brasileiro. Tal se deu para agasalhar interesses do Estado Novo na sucessão de Paul Deleuse, adiante relatada (item 5.7.4).

O princípio da irretroatividade retomou seu status constitucional apenas com a Constituição Federal de 1946, que pôs fim ao período totalitário anterior:

"CF/1946: Art. 141. A Constituição assegura aos brasileiros e aos estrangeiros residentes no país a inviolabilidade dos direitos concernentes à vida, à liberdade, à segurança individual e à propriedade, nos termos seguintes:

\section{(...)}

$\S 3^{\circ}$. A lei não prejudicará o direito adquirido, o ato jurídico perfeito e a coisas julgada"

Tal orientação foi mantida pela Constituição Federal de 1967, que repetiu o texto da Constituição Federal anterior:

“CF/1967: Art. 150130. A Constituição assegura aos brasileiros e aos estrangeiros residentes no País a inviolabilidade dos direitos concernentes à vida, à liberdade, à segurança e à propriedade nos termos seguintes:

\section{(...)}

$\S 3^{\circ}$. A lei não prejudicará o direito adquirido, o ato jurídico perfeito e a coisa julgada".

Por fim, a Constituição Federal de 1988 veio referendar tal orientação, colocando na categoria dos direitos fundamentais a proteção dos direitos adquiridos:

"CF/1988: Art. 50. Todos são iguais perante a lei, sem distinção de qualquer natureza, garantindo-se aos brasileiros e aos estrangeiros residentes no País a inviolabilidade do direito à vida, à liberdade, à igualdade, à segurança e à propriedade, nos termos seguintes:

\section{(...)}

XXXVI. A lei não prejudicará o direito adquirido, o ato jurídico perfeito e a coisa julgada".

\footnotetext{
${ }^{130}$ Depois renumerado para artigo 153.
} 
É de acordo com este texto, conjugado com a atual redação da Lei de Introdução ao Código Civil, que deverá ser pensado o direito intertemporal brasileiro.

\subsubsection{O direito intertemporal nas Leis de Introdução ao Código Civil de 1916, 1942 e 1942-1957}

Ainda quando a Constituição Federal de 1891 propugnava a não-retroatividade da lei, foi promulgada a primeira Lei de Introdução ao Código Civil, dispondo que o direito adquirido, o ato jurídico perfeito e a coisa julgada deveriam servir de limite à incidência da lei nova. Nesse sentido, a Lei ${ }^{\circ} 3.071 / 16$, depois alterada pela Lei ${ }^{\circ}$ 5.725/19, dispôs:

"LICC/1916. Art. $3^{\circ}$. A lei não prejudicará, em caso algum, o direito adquirido, o acto jurídico perfeito, ou a coisa julgada.

Este texto vigeu durante a Constituição Federal seguinte, de 1934, sendo alterado apenas com a promulgação da Constituição Federal de 1937, que silenciara a respeito da baliza intertemporal da lei nova.

O texto posterior, introduzido pelo Decreto-Lei $n^{\circ} 4.657 / 42$, traria inovações positivas e negativas à matéria. De um lado, a nova Lei de Introdução ao Código Civil adotaria a regra do efeito imediato, que permite a diferenciação entre efeito imediato e retroativo; de outro, no entanto, permeada pelo espírito revolucionário da época, abandonaria a proteção ao direito adquirido, introduzindo proteção às situações jurídicas - o que não se ajusta à tradição luso-brasileira de direito intertemporal ${ }^{131}$. Era o seguinte o texto:

"LICC/1942. Art. 6. A lei em vigor terá efeito imediato e geral. Não atingirá, entretanto, salvo disposição expressa em contrário, as situações jurídicas definitivamente constituídas e a execução do acto jurídico perfeito".

Com a Constituição Federal de 1946 - que não só pôs fim à ditadura do Estado Novo como trouxe de volta a proteção do direito adquirido ao nível constitucional - houve a

\footnotetext{
${ }^{131}$ Oportuna a lição de Rubens Limongi França, de que "nem é certo que a Constituição proteja - 'situações jurídicas', no sentido técnico da expressão" (in FRANÇA, Rubens Limongi. Direito intertemporal brasileiro: doutrina da irretroatividade das leis e do direito adquirido, cit., p. 357).
} 
necessidade de se alterar a redação da Lei de Introdução ao Código Civil de 1942. Por esta razão, foi promulgada a Lei $n^{\circ} 3.238 / 57$, que dispõe:

"LICC/42-57. Art. 6․ A lei em vigor terá efeito imediato e geral, respeitados o ato jurídico perfeito, o direito adquirido e a coisa julgada.

$\S 1^{\circ}$. Reputa-se ato jurídico perfeito o já consumado segundo a lei vigente ao tempo em que se efetuou.

$\S 2^{\circ}$. Consideram-se adquiridos assim os direitos que o seu titular, ou alguém por ele, possa exercer, como aqueles cujo começo do exercício tenha termo prefixo, ou condição preestabelecida inalterável, a arbítrio de outrem.

$\S 3^{\circ}$. Chama-se coisa julgada ou caso julgado a decisão judicial de que já não caiba recurso"

Com esta modificação, a Lei de Introdução ao Código Civil chegou a seu texto atual, que, como se viu, abarca elementos das teorias das situações jurídicas e do direito adquirido, elegendo este como limite do efeito imediato da lei, a garantir a ultratividade dos efeitos da lei revogada.

\subsubsection{Os projetos para alteração da Lei de Introdução ao Código Civil}

Segundo informa Mário Luiz Delgado, três foram as iniciativas para alteração da Lei de Introdução ao Código Civil ${ }^{132}$. A primeira delas, de 1961, mobilizou o Professor Haroldo Valladão a trabalhar em proposta abrangente que resultou no Projeto de Lei $n^{\circ}$ 264/84, posteriormente arquivado. Relata o autor que

"Em 1961, o Ministério da Justiça encomendou ao Professor Haroldo Valladão a redação de um primeiro anteprojeto, por ele denominado 'Lei Geral de Aplicação das Normas Jurídicas'. Esse anteprojeto foi concluído em 1964, mas só foi apresentado ao Congresso Nacional em 1984, pelas mão do saudoso Senador Nélson Carneiro, tendo sido posteriormente arquivado"133.

\footnotetext{
${ }^{132}$ in DELGado, Mário Luiz. Problemas de direito intertemporal no Código Civil: doutrina \& jurisprudência. São Paulo: Saraiva, 2004. p. 38-39.

${ }^{133}$ Id. Ibid., p. 38.
} 
Em 1994, em razão de nova iniciativa do Ministério da Justiça, foi apresentado outro projeto de alteração da Lei de Introdução ao Código Civil, n 4.905/95, que resultou em anteprojeto denominado "Lei de Aplicação das Normas Jurídicas", ainda em trâmite ${ }^{134}$. Se aprovado, tal projeto dará a seguinte redação às regras de direito intertemporal constantes da Lei de Introdução ao Código Civil:

\begin{abstract}
“Capítulo II - Do Direito Intertemporal
“Art. $5^{\circ}$ - Irretroatividade - A lei não terá efeito retroativo. Ela não prejudicará o direito adquirido, $\mathrm{o}$ ato jurídico perfeito e a coisa julgada.

$\S 1^{\circ}$ Direito Adquirido - Direito adquirido é o que resulta da lei, diretamente ou por intermédio de fato idôneo, e passa a integrar o patrimônio material ou moral do sujeito, mesmo que seus efeitos não se tenham produzido antes da lei nova.
\end{abstract}

$\S 2^{\circ}$ Direito a termo ou condição - Constituem igualmente direito adquirido as consequiências da lei ou de fato idôneo, ainda quando dependentes de termo ou condição.

$\S 3^{\circ}$ Ato jurídico perfeito - Ato jurídico perfeito é o consumado de acordo com a lei do tempo em que se efetuou.

$\S 4^{\circ}$ Coisa julgada - Coisa julgada é a que resulta da decisão judicial da qual não caiba recurso.

Art. $6^{\circ}$ Efeito imediato $-\mathrm{O}$ efeito imediato da lei não prejudicará os segmentos anteriores, autônomos e já consumados, de fatos pendentes.

Art. $7^{\circ}$ Alteração de prazo - Quando a aquisição de um direito depender de decurso de prazo e este for alterado por lei nova, considerar-se-á válido o tempo já decorrido e se computará o restante por meio de proporção entre o prazo anterior e o novo".

Em justificativa ao projeto, o então Ministro da Justiça Alexandre de Paula Dupeyrat Martins argumentou que

\footnotetext{
"no que tange ao direito intertemporal, procurou-se corrigir inadequações e falhas da LICC. Assim, além de proporcionar um conceito de direito adquirido assentado na melhor doutrina, o projeto trata de regular questões importantes, como a do efeito imediato e a dos direitos dependentes de prazo" ${ }^{\text {"135 }}$.
}

\footnotetext{
${ }^{134} \mathrm{O}$ projeto foi retirado de pauta para aprofundamento das discussões. Tais discussões não foram empreendidas, como deveriam, levando o Deputado Roberto Magalhães, então Presidente da Casa, ao desabafo: "já me frustrei muito nesta Casa com os chamados projetos importantes. (...) vivemos sob essa ameaça: ou fazemos leis curtas e pouco importantes, ou cuidamos de leis importantes e profundas que não vão andar" (in Diário do Congresso Nacional (Seção I), de 18 de fevereiro de 1995, p. 1996).

${ }^{135}$ in Diário do Congresso Nacional (Seção I), de 18 de fevereiro de 1995, p. 1997.
} 
Fazendo alusão a parecer elaborado por comissão de juristas instituída pela Portaria Ministerial $n^{\circ}$ 510/95, composta por João Grandino Rodas, Jacob Dollinger, Rubens Limongi França e Inocêncio Mártires Coelho, Alexandre de Paula Dupeyrat Martins deixou assentado o seguinte, em síntese:

"O art. $5^{\circ}$ reafirma expressamente a regra de que a lei não terá efeito retroativo com finalidade de obviar que a tradição de sete séculos do direito luso-brasileiro e de mais de século e meio do direito brasileiro autônomo não se alterou, desde o preceito correspondente da Constituição Imperial de 1824.

Com essa providência resolve-se a dúvida de alguns escritores que procuram ver no princípio constitucional do respeito ao direito adquirido um arrefecimento daquela norma fundamental, de onde afirmarem, sem razão, que a lei pode ter aquele efeito desde que respeite o jus aquisitum.

Ora, o princípio da Constituição de 1988, que vem desde a Introdução de 1916 e desde a Constituição de 1934, é um plus em relação ao que consta da Constituição Imperial e da Constituição republicana de 1891; e não uma sua revogação. Acrescentando mais um elemento de garantia, não o abranda, mas, ao contrário, o confirma e reforça.

A regra, pois, não é a retroatividade, senão, como sempre, desde as leis da República romana, a irretroatividade.

\section{(...)}

O projeto não repete, no art. $6^{\circ}$, como na LICC, que 'a lei terá efeito imediato e geral'.

A lei é por si uma regra geral, - comuns preceptus, na definição de Papiniano. E o efeito imediato é uma virtude natural da lei, o que já vem sendo compreendido desde que se definiu com precisão a linha divisória entre os campos da lei nova e da lei antiga; as primeiras leis da República romana, no primeiro século antes de Cristo, quando se passou a utilizar a expressão post hanc legem.

\section{(...)}

Conforme foi ficando assentado, ao longo de uma evolução de dois milênios, em relação ao efeito imediato, cumpre distinguir inicialmente três espécies de fatos: os facta praeterita, os facta futura e os facta pendentia.

Os facta praeterita - fatos passados - concernem ao domínio da lei antiga; enquanto o facta futura, - fatos futuros - dizem respeito ao da lei nova.

Já quanto aos facta pendentia - fatos pendentes - é de mister uma outra distinção, a saber, entre partes anteriores e partes posteriores.

Estas últimas respeitam igualmente ao campo da lei nova, mas as outras, ao seu turno, se situam no âmbito do mandamento da lei antiga, de tal forma que a lei nova não as pode atingir, sob pena de retroatividade. 
Não obstante, é preciso que, para tanto, sejam partes autônomas ou cindíveis, já consumadas, isto é, de algum modo subsistentes por si mesmas, sem o que constituiriam outros tantos facta pendentia. É o caso do testamento, na hipótese da herança testamentária, colhido por lei nova, depois de efetivado, antes da morte do testador. Do mesmo modo, o direito ao recurso, adquirido coma publicação da sentença, sendo o processo posteriormente atingido por lei que o tenha suprimido, como se deu com o recurso de revista, ao advento do CPC de 1973.

$\mathrm{O}$ preceito projetado no art. $7^{\circ}$ colima solucionar a magna questão concernente ao denominado direito de aquisição sucessiva, a saber, por definição, aquele que se obtém mediante o decurso de um lapso de tempo.

\section{(...)}

De onde a solução proposta, por isso que atende ao direito das partes em geral, como por exemplo, na hipótese a prescrição, ao direito adquirido, do prescribente, quanto ao prazo já escoado, bem assim ao prescribendo, quanto ao lapso por escoar (...)".

Por fim, há em curso o Projeto de Lei ${ }^{\circ}$ 243/2002, que em quase nada altera a redação da atual Lei de Introdução ao Código Civil, no que toca ao direito intertemporal, dispondo o seguinte:

"Art. $6^{\circ}$.A lei não prejudicará o direito adquirido, o ato jurídico perfeito e a coisa julgada.

$\S 1^{\circ}$. ato jurídico perfeito é o consumado de acordo com a lei do tempo em que se efetuou.

$\S 2^{\circ}$. direito adquirido é o que pode ser exercido por seu titular, ou alguém por ele, com termo prefixado, ou sob condição preestabelecida ou inalterável, a arbítrio de outrem.

$\S 3^{\circ}$. coisa julgada, ou caso julgado, é a decisão judicial de que não caiba recurso".

O direito intertemporal ganharia com a aprovação do Projeto de Lei no 4.905/95, que carreia excelente conceito de direito adquirido (artigo $5^{\circ}$, $\S \S 1^{\circ}$ e $2^{\circ}$ ), delimita com precisão o efeito imediato (artigo $6^{\circ}$ ) e prevê salutar regra de proporcionalidade para os casos de alteração de prazos (artigo $7^{\circ}$ ), o que é defendido neste trabalho (itens 3.3.3, 5.1.3, 5.1.4 e 5.5.2). 


\subsection{A quem vinculam as regras do efeito imediato e da proteção ao direito adquirido - critérios e limites para a retroatividade expressa}

Por força do artigo $6^{\circ}$, caput, da Lei de Introdução ao Código Civil, o efeito da lei será o imediato. Contudo, tal regra foi estabelecida por lei ordinária, podendo lei de igual ou maior hierarquia estabelecer efeito diverso (retroativo ou diferido), desde que não afronte o artigo $5^{\circ}$, inciso XXXVI, da Constituição Federal. Logo, a regra do efeito imediato não vincula o Legislador, mas a da proteção ao direito adquirido sim.

Vale dizer, nem mesmo o Poder Constituinte Derivado Reformador poderá violá-lo, tendo em vista que é cláusula pétrea da qual não se pode afastar - ainda mais em um país como o Brasil, em que a diferença entre uma emenda constitucional e uma lei ordinária está no número de concessões feitas para se atingir este ou aquele quorum.

Já as autoridades administrativas estarão sempre vinculadas a ambas as regras, do efeito imediato e da proteção ao direito adquirido. Adverte José Eduardo Martins Cardoso que a retroatividade, quando possível, deve constar sempre de lei, não podendo estar prevista em ato normativo inferior:

\footnotetext{
"sendo o princípio da irretroatividade da lei consagrado por lei ordinária, será também apenas por lei que a retroatividade da hipótese ou do preceito poderá ser estabelecida. Ato normativo hierarquicamente inferior à lei, como por exemplo o decreto regulamentar, não pode estabelecer para esta situação de retroatividade nela não prevista" $"$.
}

O Juiz também estará sempre vinculado às regras em comento. Contudo, caberá a este a especial tarefa de verificar, no caso concreto, se há ou não direito adquirido a justificar a ultratividade dos efeitos da lei revogada, afastando direitos aparentes que não merecem proteção contra a lei nova (item 4.2.4).

\footnotetext{
${ }^{136}$ in CARDOSO, José Eduardo Martins. op. cit., p. 516.
} 


\title{
TERCEIRA PARTE. DIREITO ADQUIRIDO E FIGURAS RELACIONADAS
}

\subsection{A natureza infraconstitucional do conceito de direito adquirido}

Há quem sustente que o artigo $5^{\circ}$, inciso XXXVI, da Constituição Federal, não comportaria nenhum tipo de regulamentação. Nelson Borges, por exemplo, sustenta que "os textos constitucionais nunca definiram o direito adquirido, dispensando-o, portanto de qualquer regulamentação (...) e o motivo é que o legislador constitucional entendeu como auto-aplicáveis tais institutos" ${ }^{\prime 137}$.

Data venia, a Lei de Introdução ao Código Civil não pretendeu conferir eficácia ao dispositivo constitucional (artigo 141 da Constituição Federal de 1946), mas estabelecer um possível sentido às expressões nele contidas. Ensina Rubens Limongi França que, "muito embora a Constituição tenha consagrado um instituto de bases assentadas na consciência jurídica nacional, essas bases não são rígidas e absolutas", competindo ao Legislador ordinário "estabelecer as lindes do conceito de Direito Adquirido"138.

É a norma infraconstitucional, portanto, que estabelecerá se e quando um direito passou a integrar o patrimônio de alguém. Por exemplo: o artigo 1.784 do Código Civil declara quando o herdeiro passa a ter direito à herança; os artigos 1.238 e seguintes determinam quando o usucapiente adquire a propriedade de imóvel; os artigos 1.653 e seguintes definem quais os bens pertencentes a cada um dos cônjuges. A Constituição Federal protege o direito adquirido, enquanto a norma infraconstitucional determina quando se dá a aquisição.

Daí o Supremo Tribunal Federal ter decidido que

\begin{abstract}
"ainda que a proteção ao direito adquirido assuma estatura constitucional - consagrada que se acha em norma de sobredireito que disciplina os conflitos das leis no tempo (CF, art. $5^{\circ}, \mathrm{XXXVI)}$-, é irrecusável que a definição dos essentialia que compõem o próprio núcleo conceitual de direito adquirido subsume-se, no delineamento de seus aspectos materiais e estruturais, ao exclusivo domínio normativo da lei comum" ${ }^{\text {"139. }}$.
\end{abstract}

\footnotetext{
${ }^{137}$ in BORGES, Nelson. Direito adquirido, ato jurídico perfeito e coisa julgada: considerações. Curitiba: Juruá, 2005. p. 44.

${ }^{138}$ in FRANÇA, Rubens Limongi. Direito intertemporal brasileiro: doutrina da irretroatividade das leis e do direito adquirido, cit., p. 404.

${ }^{139}$ STF, $1^{\text {a }}$ Turma, Ag. Reg. em Ag. Inst. no 135.632-4/RS, Rel. Min. Celso de Mello, j. 10.10.1995, v.u.
} 
Mais longe ainda foi o Superior Tribunal de Justiça, ao afirmar que

\begin{abstract}
"a compreensão dessa questão jurídica situa-se, em nosso sistema de direito positivo, em sede meramente legislativa. Sendo assim, e tendo-se presente o contexto normativo que vigora no Brasil, é na lei, e nesta somente - enquanto sedes materiae que é do tema ora em análise - que repousa o delineamento dos requisitos concernentes à caracterização do exato significado da expressão direito adquirido" ${ }^{\prime 140}$.
\end{abstract}

No entanto, evidentemente, a norma infraconstitucional não poderá prever conceito que esvazie a proteção patrimonial contida no artigo $5^{\circ}$, inciso XXXVI, da Constituição Federal. Já afirmava Rubens Limongi França que "é preciso ter em conta que um elemento já fica desde logo estabelecido: êsse conceito jamais poderá ser tão restrito que não abranja o Ato Jurídico Perfeito e a Coisa Julgada" ${ }^{\text {141 }}$.

A lei pode apenas ampliar o rol de direitos tutelados, o que o faz na menção aos direitos sob condição suspensiva. Como a pendência desta obsta a aquisição do direito (artigo 125 do Código Civil de 2002), o direito não integraria o patrimônio do titular senão pela equiparação legal feita pelo artigo $6^{\circ}, \S 2^{\circ}$, da Lei de Introdução ao Código Civil.

\title{
3.2. O conceito de direito adquirido
}

$\mathrm{O}$ artigo $6^{\circ}, \S 2^{\circ}$, da Lei de Introdução ao Código Civil, prevê genericamente que são adquiridos os direitos a termo, os direitos sob condição suspensiva e aqueles que "seu titular, ou alguém por ele, possa exercer".

A definição é insuficiente, pois nem tudo o que se pode exercer é "adquirido" (por exemplo, as faculdades jurídicas podem ser exercidas apesar de só pertencerem ao direito objetivo $)^{142}$. Só é “adquirido" o direito já integrado ao patrimônio do titular.

\footnotetext{
${ }^{140}$ STJ, Corte Especial, REsp no 274.732/SP, Rel. Min. José Arnaldo da Fonseca, j. 25.3.2004, votação por maioria. Excerto extraído do voto do Min. Fernando Gonçalves.

${ }^{141}$ in FRANÇA, Rubens Limongi. Direito intertemporal brasileiro: doutrina da irretroatividade das leis e do direito adquirido, cit., p. 404.

${ }^{142}$ Daí por que criticamos quem o conceitua tão-somente com base na Lei de Introdução ao Código Civil. Belizário Antônio de Lacerda entende que "o conceito de direito adquirido decorre da própria lei, em especial o $\S 2^{\circ}$ do art. $6^{\circ}$ da Lei de Introdução ao Código Civil (...)" (in LACERDA, Belizário Antônio de. Direito adquirido. Belo Horizonte: Del Rey, 1999); Cláudia Toledo assevera que "Direito adquirido é aquele cujo exercício não se efetivou antes da entrada em vigor da lei nova" (in TOLEDO, Cláudia. Direito adquirido e Estado democrático de direito. São Paulo: Landy, 2003). Esta visão acaba por
} 
Além disso, o direito adquirido é um direito em conflito, de que se cogita apenas em caso de choque de leis no tempo. Diferentemente do que o nomen iuris poderia indicar, o direito adquirido não é apenas um direito integrado ao patrimônio de alguém, mas aquele que não tenha sido gozado antes do advento de uma lei nova e conflitante ${ }^{143}$.

Essa espécie de direito é facilmente intuída em alguns casos, como por exemplo o do trabalhador que, embora já tivesse direito à aposentadoria, não a houvesse solicitado antes de uma lei que lhe subtraísse tal direito. Neste caso, já haveria direito ao benefício antes do advento da lei nova, e daí considerar-se-o "adquirido", isto é, incorporado ao patrimônio do titular de tal forma que, por expressa disposição constitucional, a nova norma não o pudesse atingir ${ }^{144}$.

Daí deflui o conceito clássico de direito intertemporal, de Carlos Francesco Gabba, para quem é direito adquirido

"todo direito que a) é consequiência de um fato idôneo a produzi-lo em virtude da lei do tempo em que foi realizado e cuja ocasião de fazê-lo valer não se tenha apresentado antes da atuação de uma lei nova sobre o mesmo objeto; e que b) nos termos da lei sob o império da qual ocorreu, entrou imediatamente ao patrimônio de quem o adquiriu" ${ }^{\prime 45}$.

\section{Explicando-o, Reynaldo Porchat assevera que}

“os característicos distinctivos do direito adquirido (...) são: $10^{\circ}$ um facto aquisitivo, idoneo a produzir direito, de conformidade com a lei vigente;

\footnotetext{
desprestigiar a matéria, atendo-se a um texto reconhecidamente falho e insuficiente. Por outro lado, igualmente criticáveis são posicionamentos que deixam de tratar a matéria de forma técnica. Gastão Rúbio de Sá Weyne, por exemplo, sustenta que "os direitos adquiridos, entre outros atributos, devem ser justos, e um ordenamento jurídico não pode ser considerado justo se não proteger os fracos dos fortes, os pobres dos ricos" (in WEYNE, Gastão Rúbio de Sá. Direitos adquiridos: um reexame necessário. São Paulo: Memória Jurídica, 2005. p. 31). Por mais que se veja boa vontade na afirmação, os resultados pretendidos pelo autor devem ser alcançados a partir da Constituição Federal e da Lei de Introdução ao Código Civil, sem se fazer tábula rasa da proteção dos direitos adquiridos.

${ }^{143}$ Como afirma Elival da Silva Ramos, "É expressão técnica, que tem lugar somente em caso de conflito de leis no tempo" (in RAMOS, Elival da Silva. op. cit., p. 182).

${ }^{144}$ Celso Antônio Bandeira de Mello sustenta que, mesmo que inexistisse norma constitucional de proteção ao direito adquirido, direitos como os do exemplo estariam também protegidos pela simples noção de nãoretroatividade. (in MELLO, Celso Antonio Bandeira de. op. cit., p. 15). Ousamos discordar, pois, embora a premissa seja verdadeira, a regra da não-retroatividade não vincula o Legislador, que está limitado apenas à proteção do direito adquirido, do ato jurídico perfeito e da coisa julgada.

${ }^{145}$ Tradução livre de "ogni diritto che a) è conseguenza di un fatto idoneo a produrlo, in virtù della lege del tempo in cui il fato venne compiuto, benchè l'occasione di farlo valere non siasi presentata prima dell1attuazione di una legge nuova intorno al medesimo, e che b) a termini della legge sotto l'imperio della quale accade il fatto da cui trae origine, entrò immediatamente a far parte del patrimonio di chi lo ha acquistato". (in GABBA, Carlos Francesco. op. cit., v. 1, p. 191).
} 
$2 .^{\circ}$ uma lei vigente no momento em que o facto se realize; $3 .^{\circ}$ capacidade legal do agente; $4 .^{\circ}$ ter o direito entrado a fazer parte do patrimônio, ou ter constituído o adquirente na posse de um estado civil definitivo; $5 .^{\circ}$ não ter sido exigido ainda ou consumado esse direito, isto é, não ter sido ainda realizado em todos os seus effeitos" ${ }^{\prime 146}$.

Já Rubens Limongi França observa que a idéia de "patrimônio" deve abarcar também o moral, e que, "no conceito em tela [de Carlos Francesco Gabba], não está consignada, ou quando menos, não ficou suficientemente esclarecida, a possibilidade de haver Direito Adquirido em conseqüência imediata de disposição de lei, sem a incidência de um fato ou ato jurídico em particular" ${ }^{147}$. Nesse contexto, propõe o seguinte conceito: "é a conseqüência de uma lei, por via direta ou por intermédio de fato idôneo; consequiência esta que, tendo passado a integrar o patrimônio material ou moral do sujeito, não se fez valer antes da vigência de lei nova sôbre o mesmo objeto" ${ }^{\text {"148. }}$.

Conceituamos direito adquirido como aquele que, ao tempo da lei revogada, estava integrado ao patrimônio ou pendente de termo ou condição suspensiva.

Com a menção a "lei revogada", indicamos que a expressão só deverá ser considerada em caso de sucessão de leis; com a alusão a "patrimônio", garantimos que se está diante de direito efetivamente adquirido, e não de mera faculdade jurídica; ao nos referirmos a "termo ou condição", abrangemos direitos que a rigor ainda não fariam parte do patrimônio, mas que devem ser considerados adquiridos em razão de equiparação legal, dos artigos 131 do Código Civil de 2002 e $6^{\circ}$, § $2^{\circ}$, da Lei de Introdução ao Código Civil ${ }^{149}$.

\footnotetext{
${ }^{146}$ in PORCHAT, Reynaldo. op. cit., p. 15.

${ }^{147}$ in FRANÇA, Rubens Limongi. Direito intertemporal brasileiro: doutrina da irretroatividade das leis e do direito adquirido, cit., p. 431.

${ }^{148}$ Id. Ibid., p. 431.

${ }^{149}$ A nosso ver, não há razão para se mencionar "conseqüência de uma lei”, pois todos os fatos tutelados pelo direito intertemporal decorrem de uma lei que haja sido substituída por outra; não aludimos a "por via direta ou por intermédio de fato idôneo", pois importa apenas que o direito integre o patrimônio, não interessando a forma como se tenha dado sua aquisição; não distinguimos "material" ou "moral”, pois se é para abranger não há por que diferenciar.
} 


\subsection{Os modos de aquisição dos direitos}

Em um sistema que proíbe não a retroatividade mas a ofensa a direitos adquiridos, é da maior importância determinar quando o direito passou a integrar o patrimônio, a fím de se verificar se a aquisição se deu antes ou depois do advento da lei nova.

Na lição de Daisy Gogliano, “a aquisição (...) pode ser definida como o ato ou efeito de adquirir, i.e., tornar-se possuidor de, alcançar, conseguir" ${ }^{\prime 150}$. Explica que tal se dará "no momento em que o fato jurídico incide sobre o direito objetivo (norma agendi) que na sua existência é de natureza estática e eidética e que logo após, passa a ser dinâmico e concreto" $" 151$.

O momento do nascimento não necessariamente se confunde com o da aquisição do direito, que, no dizer de Caio Mário da Silva Pereira, "é a conjunção do direito com seu titular atual" 152 , ou seja, "uma configuração subjetiva","153, enquanto "o nascimento de um direito é objetivo" ${ }^{154}$. Só haverá aquisição de um direito, portanto, quando este se ligar a um sujeito, o que, segundo Daisy Gogliano, ocorre “em virtude da própria lei, por via direta ou por intermédio de um ato ou fato jurídico que faz com que ocorra a adesão da relação jurídica ao seu sujeito" ${ }^{\prime 155}$.

Esta “adesão" se dará, na observação de Rubens Limongi França, "em conseqüência de um elemento fundamental único"156 ou "da realização de vários elementos" $"$. Daí propor o estudo particularizado dos vários modos de aquisição dos direitos, que o faz dividindo-os em direitos de aquisição simples e complexa. De acordo com o autor, a análise dessas espécies possibilita estabelecer o momento em que o direito entra para o patrimônio do sujeito, de forma a "esclarecer quando se efetiva a aquisição de

\footnotetext{
${ }^{150}$ GOGLIANO, Daisy. Aquisição. In: FRANÇA, Rubens Limongi (Org.). Enciclopédia Saraiva do Direito. São Paulo: Saraiva, 1977. v. 7, p. 309.

${ }^{151}$ Id. Ibid., p. 310.

${ }^{152}$ PEREIRA, Caio Mário da Silva. op. cit., v. 1, p. 325.

${ }^{153}$ Id. Ibid.

${ }^{154}$ Id. Ibid. No mesmo sentido é o ensinamento de Carlos Maximiliano, de que "existência dos direitos não se confunde com aquisição: esta abrange o direito no sentido subjetivo; aquela, no objetivo" (in MAXIMILIANO, Carlos. op. cit., p. 205).

${ }^{155}$ GOGLIANO, Daisy. op. cit., p. 316-317.

${ }^{156}$ FRANÇA, Rubens Limongi. Direito intertemporal brasileiro: doutrina da irretroatividade das leis e do direito adquirido, cit., p. 466.

${ }^{157}$ Id. Ibid.
} 
cada uma e, conseqüentemente, o caminho a ser seguido, em cada caso, para a solução dos problemas de Direito Intertemporal" ${ }^{\prime 158}$.

A orientação tem respaldo na lição de Carlos Francesco Gabba, para quem

"Os fatos aquisitivos são simples ou complexos. Simples são aqueles que se consumam em um só instante, isto é, não possuem partes sucessivas, distanciadas por um intervalo de tempo. São complexos aqueles que se compõem de partes que se consumam separadamente e com distância de tempo entre uma e outra" ${ }^{, 159}$.

Como um direito pode ser adquirido em razão de uma somatória de elementos, é necessário analisar se todos eles se perfizeram antes do advento da lei nova; só aí poderá decidir o intérprete se existe direito adquirido ou se seu "ciclo de formação" 160 não houvera se completado.

Esta verificação será feita pelo estudo dos diversos modos de aquisição dos direitos, a determinar quais elementos são estes e quando sua conjunção resulta em aquisição efetiva. Para evidenciar a utilidade do exame, confrontá-lo-emos com a doutrina e a jurisprudência dos tribunais superiores, demonstrando como devem ser resolvidas as questões de direito intertemporal envolvendo direitos adquiridos.

\subsubsection{Os direitos de aquisição simples}

Conforme define Rubens Limongi França, os direitos de aquisição simples são "aquêles que se auferem em conseqüência de um elemento fundamental único, seja ele a lei ou um fato jurídico" ${ }^{\text {161. }}$.

\footnotetext{
${ }^{158}$ FRANÇA, Rubens Limongi. Direito intertemporal brasileiro: doutrina da irretroatividade das leis e do direito adquirido, cit., p. 467.

${ }^{159}$ GABBA, Carlos Francesco. op. cit., v. 1, p. 228. Tradução livre de: "I fatti acquisitivi invero altre sono semplici, altri complessi. Semplici sono quelli i quali si compiono in un solo istante, cioè non presentano parte sucessive, separate necessariamente da intervalli di tempo. Sono complessi quelli $i$ quali si compongono di parti che si compiono separatamente e a distanza di tempo l'una dall'altra".

${ }^{160}$ Expressão forjada pelo Ministro Celso de Mello (STF, 2a Turma, Ag. Reg. no RE n ${ }^{\circ} 322.348 / \mathrm{SC}$, Rel. Min. Celso de Mello, j. 12.11.2002, v.u.).

${ }^{161}$ FRANÇA, Rubens Limongi. Direito intertemporal brasileiro: doutrina da irretroatividade das leis e do direito adquirido, cit., p. 466.
} 
Para verificar se um direito de aquisição simples é ou não adquirido, basta tomar-se a lei nova como referência e verificar se o direito em questão lhe é anterior ou posterior. Os direitos anteriores à nova norma serão considerados direitos adquiridos, pois nasceram e passaram a integrar o patrimônio sob a égide da lei revogada; os direitos nascidos depois do início da vigência da lei nova, contudo, não serão considerados adquiridos, pois nasceram da incidência do novo diploma e não poderiam se valer dos efeitos da lei revogada.

Assim, por exemplo, um contrato aperfeiçoado em um só ato será regulado, em seu todo, pela lei vigente ao tempo em que foi subscrito, incluindo as prestações vincendas e eventuais conseqüências pendentes. Nesse sentido decidiu o Ministro Marco Aurélio Mello, afirmando que "a regência do contrato faz-se, pouco importando o desdobramento em prestações sucessivas, pela lei em vigor na data em que formalizado"162.

O que importa não é a complexidade do direito, mas, sim, o modo como é adquirido ${ }^{163}$. Embora tenha se prolongado no tempo, o direito em exemplo surgiu em decorrência de um “elemento fundamental único", e, como este ocorreu antes do advento da lei nova, será considerado "direito adquirido".

Conforme afirma Celso Antônio Bandeira de Mello, "por meio deste instituto, a ordem jurídica prestigia a autonomia da vontade ao ponto de propiciar-lhe o poder de fazer ajustes cuja força específica é atrair para o presente eventos a serem desenrolados em um futuro às vezes distante" ${ }^{\prime 164}$.

Essa ordem de direitos não apresenta maiores dificuldades, pois não deixa dúvidas quanto ao seu momento de aquisição. À frente serão analisados direitos que, por não se verificarem em um único momento, podem gerar dúvida quanto à sua configuração como adquiridos.

Por se adquirirem em razão da conjunção de mais de um fator, tais direitos são chamados de "direitos de aquisição complexa", e serão aqui subdivididos em "direitos de aquisição por elementos autônomos" e "direitos de aquisição por elementos dependentes".

\footnotetext{
${ }^{162}$ STF, Pleno, RE no 134.570/RS, Rel. Min. Marco Aurélio Mello, j. 15.3.2006, v.u.

${ }^{163}$ Conforme já o alertava Rubens Limongi França (in FRANÇA, Rubens Limongi. Direito intertemporal brasileiro: doutrina da irretroatividade das leis e do direito adquirido, cit., p. 466).

${ }^{164}$ in MELLO, Celso Antonio Bandeira de. op. cit., p. 23.
} 
Antes, porém, de abordar os direitos de aquisição complexa, analisaremos os direitos a termo e os direitos sob condição suspensiva, que, embora de aparente aquisição complexa, devem ser tratados como subespécie dos direitos de aquisição simples, em razão de equiparação legal.

\subsubsection{Os direitos a termo}

Embora a rigor os direitos a termo sejam direitos de aquisição complexa, pois dependem não só da ocorrência de um ato mas também da verificação de um evento futuro - tal qual se dá com a condição (item 3.3.1.2) -, o artigo 131 do Código Civil dispõe que "o termo inicial suspende o exercício, mas não a aquisição do direito"165. Quer dizer: para o Código Civil, o direito a termo é considerado adquirido desde a data do ato no qual esteja estipulado, pouco importando o momento da ocorrência do evento nele previsto.

Como ensina Clovis Bevilaqua, "o termo inicial suspende o exercício, mas não a aquisição do direito, que já se deve considerar potencialmente existente em nosso patrimônio (praesens obrigatio est, in diem autem dilata solutio)" ${ }^{166}$. Assim, embora por definição seja o termo "instante ou dia certo a partir do qual deve começar ou no qual deve extinguir-se a eficácia de um ato jurídico" ${ }^{\text {167 }}$, este não impede a aquisição do direito, mas tão-somente o seu exercício - isto é, haverá efeitos do ato (aquisição de um direito), mas estes ficarão suspensos e só poderão ser exercidos com o advento do evento futuro e certo.

Rubens Limongi França observa que a equiparação entre os direitos a termo e os direitos efetivamente adquiridos decorre de um certo paralelo entre tais obrigações e as obrigações periódicas. Afirma que "a mesma razão, que leva a considerar Direito Adquirido os efeitos de um negócio jurídico a ser executado em diversas quotas, conduz ao reconhecimento de que igualmente se passa com os direitos a têrmo"168.

A rigor, afigurar-se-ia desnecessária a menção, no artigo $6^{\circ}, \S 2^{\circ}$, da Lei de Introdução ao Código Civil, a direitos com "termo pré-fixo". Os direitos a termo já seriam adquiridos pela expressa disposição contida no artigo 131 do Código Civil, não necessitando de menção

\footnotetext{
${ }^{165}$ Tal artigo tem correspondência com o artigo 123 do Código Civil de 1916.

${ }^{166}$ in BEVILÁQUA, Clovis. Teoria geral do direito civil. Campinas: RED Ed., 2003. p. 229.

${ }^{167}$ in FRANÇA, Rubens Limongi. Direito intertemporal brasileiro: doutrina da irretroatividade das leis e do direito adquirido, cit., p. 451.

${ }^{168}$ Id. Ibid., p. 452.
} 
na Lei de Introdução ao Código Civil para gozar da proteção constitucional. Razão assiste a Rubens Limongi França, para quem "a própria referência aos casos de têrmo inicial nos parece dispensável, pois, segundo o art. 123 do Código Civil [atual artigo 131 do Código Civil], o dies a quo 'suspende o exercício, mas não a aquisição do direito",169.

A Lei de Introdução ao Código Civil faz referência aos direitos a termo provavelmente para se adequar à impropriedade contida no artigo $6^{\circ}$, caput, daquele diploma, segundo o qual seriam adquiridos os direitos que o titular "pode exercer". Como os direitos a termo não podem ser "exercidos" - embora considerados adquiridos pelo artigo 131 do Código Civil -, a Lei de Introdução ao Código Civil teve de incluí-los, de forma expressa, entre os direitos tratados no seu artigo $6^{\circ}, \S 2^{\circ}$.

Partindo-se de um conceito técnico de direito adquirido, que considere o conteúdo patrimonial e não a possibilidade de exercício do direito, seria desnecessária a equiparação feita pela Lei de Introdução ao Código Civil. Os direitos a termo são protegidos da lei nova porque o artigo 131 do Código Civil os considera adquiridos desde o dia da celebração do negócio, recebendo, por isso, tratamento idêntico aos direitos de aquisição simples.

\subsubsection{Os direitos sob condição suspensiva}

Conforme aludido no item anterior, os direitos sob condição suspensiva também deveriam ser tratados como direitos de aquisição complexa, pois sua eficácia depende não apenas da existência de um ato mas também da ocorrência de evento futuro contratualmente previsto $^{170}$. Não destoa o Código Civil ao dispor que "subordinando-se a eficácia do negócio jurídico à condição suspensiva, enquanto esta se não verificar, não se terá adquirido o direito, a que ele visa" (artigo 125).

Como se vê, no caso dos direitos sob condição suspensiva, só se poderia falar em direito adquirido quando do advento do evento futuro e incerto; antes disso, a rigor o ato não estaria protegido contra os efeitos da lei nova. Contudo, o artigo $6^{\circ}, \S 2^{\circ}$, da Lei de

\footnotetext{
${ }^{169}$ FRANÇA, Rubens Limongi. Direito intertemporal brasileiro: doutrina da irretroatividade das leis e do direito adquirido, cit., p. 452.

${ }^{170}$ Estar-se-á diante de condição quando a eficácia do negócio jurídico estiver subordinada a evento futuro e incerto (artigo 121 do Código Civil). Na lição de Clovis Bevilaqua, "condição é a determinação acessória, que faz a eficácia da vontade declarada dependente de algum evento futuro e incerto" (in BEVILÁQUA, Clovis. op. cit., p. 222).
} 
Introdução ao Código Civil, referiu-se expressamente à "condição preestabelecida inalterável, a arbítrio de outrem"171, ampliando o conceito de direito adquirido.

Muito se discutiu na doutrina se essa ampliação teria criado uma contradição entre a Lei de Introdução ao Código Civil e o artigo 125 do Código Civil. A nosso ver a suspeita improcede, tendo em vista que, estando o direito adquirido incluído no rol dos direitos fundamentais (artigo $5^{\circ}$ da Constituição Federal), não há vedação a que se lhe confira interpretação ampliativa. Conforme assinala Rubens Limongi França, o preceito contido no artigo 125 do Código Civil remete ao direito das partes, enquanto a Lei de Introdução ao Código Civil ocupou-se da segurança jurídica, privilegiando a estabilidade das relações jurídicas ${ }^{172}$.

Além disso, a condição suspensiva possui efeito retroativo, de modo que, verificado o efeito futuro e incerto, considera-se adquirido o direito desde o momento em que foi estipulada. Na lição de Clovis Bevilaqua, "realizada a condição suspensiva, o direito corporifica-se e considera-se existente, desde o momento em que se deveria constituir, se o não deferisse a condição, isto é, o dia da celebração do ato inter vivos ou do falecimento do testador" " Vicente Ráo já o dizia: "o direito sujeito a condição é, pois, um direito condicional adquirido, direito adquirido, isto é, à titularidade do direito visado pelo ato jurídico, quando se realizar a condição" ${ }^{, 174}$.

No mesmo sentido é a lição de Reynaldo Porchat, preocupado em distinguir o direito sob condição suspensiva das meras expectativas de direito:

\begin{abstract}
"deve-se observar que o direito adquirido condicionado tem todos os elementos de um direito adquirido, e já se concretisou em utilidade para o indivíduo (...) Porisso, no direito condicionado o adimplemento da condição, mesmo que se verifique sob o domínio de uma lei nova, tem effeito retroactivo, de modo que o direito se considera como real e effectivo desde o momento em que nasceu sob condição" ${ }^{\text {"175 }}$.
\end{abstract}

\footnotetext{
${ }^{171}$ Expressão esta - "inalterável, a arbítrio de outrem” - tida por desnecessária pela doutrina majoritária. A expressão remete às condições potestativas, as quais são vedadas pelo artigo 122 do Código Civil. A esse respeito, vide a lição de Rubens Limongi França (in FRANÇA, Rubens Limongi. Direito intertemporal brasileiro: doutrina da irretroatividade das leis e do direito adquirido, cit., p. 459-461) e Clovis Bevilaqua (in BEVILÁQUA, Clovis. op. cit., p. 223).

${ }^{172}$ in FRANÇA, Rubens Limongi. Direito intertemporal brasileiro: doutrina da irretroatividade das leis e do direito adquirido, cit.,. p. 456 e 457-458.

${ }^{173}$ in BEVILÁQUA, Clovis. op. cit., p. 226.

${ }^{174}$ in RÁO, Vicente. Ato jurídico. São Paulo: Max Limonad, 1961. p. 290.

${ }^{175}$ in PORCHAT, Reynaldo. op. cit., p. 31-32.
} 
Em parecer sobre direitos adquiridos e aumento progressivo de funcionários públicos do sistema educacional, Clovis Bevilaqua traz interessantes exemplo e ponderação que põem fora de dúvidas a questão da ausência de conflito entre o Código Civil e a Lei de Introdução ao Código Civil:

"Uma lei assegura, aos lentes de um estabelecimento de instrucção publica, o augmento progressivo dos respectivos vencimentos, de accordo com o tempo de serviço. Lei posterior retira esse direito de augmento progressivo. Trata-se de saber se os lentes nomeados na vigencia da primeira lei perderam, em virtude da nova lei, esse direito assegurado pela lei anterior.

A questão é de irretratabilidade de promessa feita por uma parte e acceita por outra, creando obrigação de cumpril-a e direito de exigil-a.

Essa promessa tornou-se obrigatória, eis que os professores receberam a sua investidura no cargo. A promessa acceita é um contracto, e este não se rompe ao alvedrio da parte que se obriga. Este principio deve ser ainda mais imperioso para o Estado do que para os particulares, porque o Estado é organismo social cuja funç̧ão principal é realizar o direito, legislando, julgando, administrando, e que, portanto, vive do direito e para o direito.

O accrescimo dos vencimentos dependia apenas, para os professores em exercício ao tempo da primeira lei, de se acharem em funcção, no momento prefixado para o augmento. É uma condição. Pendente a condição, não se alteram as relações jurídicas, cuja efficacia depende do implemento della.

No caso da consulta, o Estado, na mencionada lei, declarou que os professores, no fim de dez annos, perceberiam mais a quarta parte de seus vencimentos; no fim de quinze, mais a terça parte; no fim de vinte e cinco, mais a metade. Não tem direito de declarar, antes de decorridos os mencionados prazos, que não pagará mais os prometidos augmentos. Está vinculado por sua promessa, e deve cumpri-la, desde que se realize a condição, a que a subordinou: se o professor se achar no exercício do cargo, no tempo determinado; se o exercer por dez, quinze ou vinte e cinco annos. A lei posterior pode, sem duvida, abolir esses accrescimos; mas sómente em relação aos profesores nomeados na sua vigência.

O art. 118 do Código Civil [atual artigo 125 do Código Civil] não pode ser embaraço a esta solução. Declara elle que, emquanto não se verificar a condição, não se considera o direito adquirido. Quer isto, apenas, dizer que, pendendo a condição, o direito não pode ser exercido, nem a obrigação exigida; mas o bem juridico já está no patrimonio do titular; com o seu carater eventual é certo, porem esse carater não o priva, inteiramente, de valer. O destino do condicional é tornar-se real, e, emquanto não se resolve esse destino, a utilidade, o valor econômico do bem esperado merece a protecção do direito. E esta não lhe recusas o nosso Código Civil, como se vê do art. 3 da Introducção, onde está declarado que a lei não prejudicará, em caso algum, o direito adquirido, definido como sendo o que o titular pode exercer, e aquelle cujo começo 
de exercicio tenha termo prefixado ou condição preestabelecida, inalteravel a arbitrio de outrem.

Não há antinomia entre o art. $3, \S 1 .^{\circ}$ da Introducção do Código Civil, que considera adquirido o direito subordinado á condição suspensiva, e o art. 118, que declara ainda não adquirido o direito antes de realizada a condição, a que está subordinado. $\mathrm{O}$ art. 3 da Introducção refere-se á irretroactividade das leis, e estatue que estas não podem offender o direito, cujo começo de exercicio dependa de condição preestabelecida. É um bem jurídico; é valor apreciavel; a lei deve respeital-o. O art. 118 colloca-se no ponto de vista da formação do direito, e declara que, antes de verificada a condição, não pode ser exercido o direito a ella subordinado. Aqui, o direito é considerado como poder de acção em face de outros poderes do mesmo genero, e declarando-o não adquirido, que a lei dizer que ainda não está definitivamente formado, e por isso ainda não pode ser exercido. Ali, o direito se diz adquirido, para que a lei nova não intervenha, perturbando a sua formação em via de completar-se" ${ }^{176}$.

Ou seja: a Lei de Introdução ao Código Civil houve por bem proteger não só os direitos efetivamente adquiridos como também o exercício futuro de direitos em potencial, tal como aqueles diferidos ao advento de evento futuro e incerto. Daí por que o direito sob condição suspensiva gozará da mesma proteção conferida ao direito adquirido. Por equiparação da Lei de Introdução ao Código Civil, considera-se direito adquirido aquele sob condição suspensiva, para o fim exclusivo de conflito de leis no tempo.

Por fim, mencione-se que, no caso das condições resolutivas, haverá aquisição de direito desde o momento em que houver sido entabulado o negócio condicionado, tendo em vista dispor o artigo 127 do Código Civil que "se for resolutiva a condição, enquanto esta não se realizar, vigorará o negócio jurídico, podendo exercer-se desde a conclusão deste o direito por ele estabelecida". Os direitos sob condição resolutiva devem receber o mesmo tratamento dispensado aos direitos de aquisição simples ${ }^{177}$.

\subsubsection{Os direitos de aquisição complexa}

Os direitos também podem ser adquiridos de forma complexa, isto é, pela conjunção de diversos elementos. Nesses casos, somente quando a aquisição estiver completa é que o

\footnotetext{
${ }^{176}$ in BEVILÁQUA, Clovis. Soluçães práticas de direito (Pareceres). Rio de Janeiro: Corrêa, Bastos, 1923. v. 1. p. 21-23.

${ }^{177}$ No dizer de Vicente Ráo, "a situação do titular do direito sujeito a condição resolutiva se equipara à do titular do direito incondicional ou puro. (in RÁO, Vicente. Ato jurídico, cit., p. 334).
} 
direito poderá ser considerado adquirido, e, por conseguinte, regido pelos efeitos ultrativos da lei revogada. Isto, inclusive, é o que já constava do Anteprojeto de Lei-Geral de Aplicação das Normas Jurídicas, de Haroldo Valladão:

"Art. 82. Os fatos iniciados, porém, ainda não completados, regem-se segundo a lei nova, reconhecidos os respectivos elementos autônomos que se realizaram validamente de acordo com a lei anterior" ${ }^{\prime 178}$.

Do citado projeto: se a aquisição do direito depender da conjunção de elementos diversos, a norma antiga só continuará a regê-lo se verificados todos. Caso a lei nova entre em vigor antes da realização de todos os elementos, de duas uma: se dependentes, a nova lei atingirá o direito; caso, ao contrário, encerrem direitos individualizáveis, a nova lei não poderá atingir as partes anteriores, pois serão consideradas - de forma autônoma - direitos adquiridos sob a égide da norma revogada.

É o que a melhor doutrina tem proposto na Itália. A esse respeito, comenta Rolando Tarchi:

“(...) distinguem-se as hipóteses em que o fato aquisitivo da relação jurídica ainda está incompleto (ou o fato extintivo) e aquela em que o fato gerador está perfeito, mas deve ainda produzir seus efeitos. Os dois casos não se mostram de todo análogos. No segundo, de fato, a eficácia imediata da lei nem sempre pode impedir a produção dos efeitos (...."179.

Seguindo a proposta, trataremos os direitos de aquisição complexa em duas categorias $^{180}$, quais sejam: (1) aquisição por elementos autônomos; e (2) aquisição por elementos dependentes.

\footnotetext{
${ }^{178}$ Conforme informa Rubens Limongi França (in FRANÇA, Rubens Limongi. Direito intertemporal brasileiro: doutrina da irretroatividade das leis e do direito adquirido, cit., p. 466).

${ }^{179}$ in TARCHI, Rolando. op. cit., p. 155-156. Tradução livre de “(...) si distingue tra l'ipotesi in cui è ancora incompleto il fatto costitutivo (o anche quello estintivo) del rapporto, e quella in cui il fatto generatore è perfetto, ma devono ancora prodursi gli effetti. I due casi non si presentano come del tutto analoghi. Per il secondo, infatti, l'efficacia immediata della legge non sempre può impedire la produzione degli effetti stessi (...)".

${ }^{180}$ Rubens Limongi França propôs que as formas de aquisição fossem classificadas em quatro categorias: (1) direitos de aquisição imperfeita, compreendendo os direitos sob condição suspensiva e a termo; (2) direitos de aquisição sucessiva, que se adquiririam mediante o transcurso do tempo; (3) direitos de aquisição por partes, que se aufeririam "mediante a perfeição autônoma de vários elementos"; e (4) direitos de aquisição plural, assim chamados "aquêles que se incorporam ao nosso patrimônio em virtude de causas diversas de valor suficiente" (in FRANÇA, Rubens Limongi. Direito intertemporal brasileiro: doutrina da irretroatividade das leis e do direito adquirido, cit., p. 467). Com a máxima vênia para dissentir do grande
} 


\subsubsection{Os direitos de aquisição por elementos autônomos}

Os direitos de aquisição por elementos autônomos são aqueles cujas partes constituem direitos individualizáveis. Ensina Rubens Limongi França tratar-se de direitos em que "cada causa principal é suficiente para gerar Direito Adquirido"181.

Neste caso, haverá direito adquirido com relação a cada fato aquisitivo que tiver se completado antes do advento da lei nova. Rubens Limongi França traz exemplo que põe a salvo de dúvida a questão:

"Figuremos agora a modificação, trazida pela lei nova, da forma de certo testamento. Ficou assentado o princípio de que, nos direitos de aquisição por partes, o estatuto modificador não atinge os elementos vàlidamente realizados de acôrdo com a lei modificada. Ora, o direito à sucessão testamentária é dessa natureza, sendo o testamento uma de suas partes. Ergo, o testamento é válido a despeito de sua forma ser a antiga"182.

Conforme leciona o autor, nos direito de aquisição por elementos autônomos - que denomina "direitos de aquisição por partes" - a regra "é a da aplicação da lei do tempo da perfeição de cada fato aquisitivo" ${ }^{\prime 183}$.

professor do direito intertemporal, essa divisão não será acatada, pelas seguintes razões: (1) os "direitos de aquisição imperfeita" devem ser tratados como de aquisição simples, em razão da equiparação legal; (2) com relação aos "direitos de aquisição sucessiva", entendemos que eles não se adquirem "dia-a-dia", como entende o excelentíssimo professor, mas sim de uma única vez, quando transcorrido todo o lapso de tempo que a lei prevê para sua aquisição. Assim o é, por exemplo, com relação à aposentadoria, que só poderá ser pleiteada depois do transcurso de todo o tempo necessário para a concessão do benefício. Embora certo que, se já transcorrido grande período, eventual alteração das regras poderia representar terrível injustiça, por desconsiderar o tempo já passado, por certo também esse prazo não poderia ser considerado "direito adquirido". Para se corrigir tal distorção, será necessário o auxílio de outras regras e princípios, assumindose que a teoria dos direitos adquiridos não é capaz de solucionar todos os problemas causados pela sucessão conflitual de leis, assim como qualquer outra também não o seria. Tanto que o próprio Rubens Limongi França propõe uma regra de eqüidade nos casos de diminuição dos prazos processuais, o que é inteligentíssimo mas data venia não tem relação estrita com a questão da aquisição de direitos. Tal sorte de direitos será delineada adiante, quando se tratar do "direito adquirido proporcional" - expressão forjada pelo Professor Celso Antônio Bandeira de Mello; (3) aceitamos a existência dos direitos de aquisição por partes e dos direitos de aquisição plural, assim como concebida na inestimável obra de Rubens Limongi França. Contudo, chamá-los-emos de "direitos de aquisição por elementos dependentes" e "direitos de aquisição por elementos autônomos", tendo em vista que, como a única diferença que há entre os direitos de aquisição complexa são a autonomia das partes que os formam, será mais didático classificá-los tãosomente em razão disto.

${ }^{181}$ in FRANÇA, Rubens Limongi. Direito intertemporal brasileiro: doutrina da irretroatividade das leis e do direito adquirido, cit., p. 474. No texto, Rubens Limongi França está a se referir aos "direitos de aquisição plural".

${ }^{182}$ Id. Ibid., p. 511.

${ }^{183}$ in Id. Ibid., p. 474. 


\title{
3.3.2.2. Os direitos de aquisição por elementos dependentes
}

Os direitos de aquisição por elementos dependentes são aqueles cujas partes só constituem direito quando consideradas em conjunto. Só há direito se verificados todos os elementos necessários à aquisição.

Exemplo dos direitos de aquisição por elementos dependentes vê-se em julgado do STF no âmbito do qual o Ministro Paulo Brossard decidiu que, para ser devida a reposição salarial da Lei no 7.830/89, seria necessária a conjunção de mais de um elemento, sem o que não se o poderia considerar o direito "adquirido". Conforme afirmou,

\begin{abstract}
"o aperfeiçoamento do direito (...) ficou impedido, em virtude da falta de um dos seus elementos integralizadores, no caso, a implementação do tempo exigido para a incidência da regra de revisão outrora vigorante, abolida por lei posterior. $\mathrm{O}$ que se frustrou não passava de expectativa de continuidade do critério ou regime da fixação de remuneração futura, e isso o Supremo Tribunal, uniformemente, tem-se recusado a admitir como direito adquirido" ${ }^{, 184}$.
\end{abstract}

Quando a lei nova se depara com um direito não completamente formado, ela terá aplicação imediata, impedindo a completa aquisição. Esta a lição de Carlos Francesco Gabba: “(...) os fatos aquisitivos ainda não completos constituem mera expectativa e não geram direito adquirido à sua aquisição completa" ${ }^{2185}$.

O ponto é referendado pelo Ministro Celso Mello, que observa que

\begin{abstract}
"a superveniência de ato legislativo (...) constitui fator capaz de impedir que se complete, legitimamente, o próprio processo de aquisição do direito (...), inviabilizando, desse modo, ante a existência de mera 'spes juris', a possibilidade de útil invocação da cláusula pertinente ao direito adquirido" ${ }^{, 186}$.
\end{abstract}

Isto porque - antes alertara o Ministro Octavio Gallotti - "para a aquisição do direito, ou seja, para ingresso deste no patrimônio do pretenso titular, seria mister que, antes

\footnotetext{
${ }^{184}$ STF, $2^{\text {a }}$ Turma, RMS no 21774/DF, Rel. Min. Paulo Brossard, j. 4.10.1994, v.u.

${ }^{185}$ GABBA, Carlos Francesco. op. cit., v. 1, p. 229. Tradução livre de: “(...) i fatti acquisitivi, non ancora completi, producano una mera aspettativa, e non contengano un diritto acquisto al loro compimento".

${ }^{186}$ STF, $2^{\text {a }}$ Turma, Ag. Reg. no RE no 322.348/SC, Rel. Min. Celso de Mello, j. 12.11.2002, v.u.
} 
da revogação, se houvessem reunido e consumado todos os elementos isto é, os fatos idôneos à sua constituição ou produção" $" 187$.

Como ensina Reynaldo Porchat, "não se póde admitir direito adquirido a adquirir um direito" $" 188$.

\subsubsection{O direito adquirido proporcional - a questão da alteração do prazo para aquisição de um direito}

Como se viu, em regra os conflitos de lei no tempo podem ser resolvidos pela verificação do momento da aquisição do direito: se adquirido antes do advento da lei nova, o direito goza da proteção constitucional, o que também vale para as partes autônomas e anteriores de um direito não totalmente formado. Por outro lado, se o direito não tiver sido adquirido, a lei nova o atinge, inclusive nas partes pendentes de outros elementos aquisitivos - exceção feita aos direitos sob condição suspensiva e a termo.

Contudo, tal regra não resolve um tormentoso problema da sucessão conflitual de normas: a alteração do prazo para aquisição de um direito. Dentre os direitos de aquisição por elementos dependentes, há aqueles que só se adquirem com o passar do tempo, como por exemplo o direito à aposentação: apenas depois dos anos de contribuição previstos na lei é que o contribuinte adquirirá direito ao benefício.

Conforme já referido, refutamos a idéia de que tais direitos sejam de aquisição sucessiva, ou seja, direitos que se adquiririam "dia a dia", um pouco a cada momento. Em verdade, o passar dos dias apenas aproxima esses direitos da aquisição, que só se consumará quando do transcurso de todo o período aquisitivo. O direito a se aposentar, por exemplo, só existirá depois de passados todos os longos anos de expectativa pelo benefício ${ }^{189}$.

\footnotetext{
${ }^{187}$ STF, Pleno, MS n ${ }^{\text {o }}$ 21.216-1/DF, Rel. Min. Octavio Gallotti, j. 5.12.1990, votação por maioria.

${ }^{188}$ in PORCHAT, Reynaldo. op. cit., p. 23.

${ }^{189}$ Hipótese que não se confunde com a do artigo 811 do Código Civil de 2002, segundo o qual "o credor adquire a renda dia a dia, se a prestação não houver de ser paga adiantada, no começo de cada um dos períodos prefixo". Neste caso, todo dia se adquire uma porcentagem da renda, que se tornará exigível na data pré-fixa.
} 
Isto significa que se lei nova extinguir o direito expectado o sujeito não fará jus ao direito, nem no todo nem em parte. No caso do exemplo, se lei nova acabar com o direito de se aposentar antes de transcorrido todo o prazo para aquisição do benefício o contribuinte não terá direito a aposentar-se.

E se lei nova, ao invés de extinguir, apenas alterar o prazo para aquisição do direito? No caso do exemplo: e se lei nova dispuser que o direito à aposentação, que antes nascia após 20 anos de contribuição, só existirá depois de 30 anos contribuindo?

Decerto aplica-se o prazo novo, pois a lei nova tem efeito imediato e pode alterar desde logo o tempo necessário para aquisição de um direito. Contudo, isto não significa que o sujeito terá de percorrer todo o período faltante para o novo prazo para só então adquirir o direito. No caso do exemplo, se o contribuinte tiver contribuído durante 10 anos para a Previdência Social, não terá que contribuir outros 20 para aposentar-se.

Com a argúcia que lhe é peculiar, Celso Antônio Bandeira de Mello observa que "fatos pretéritos, mas que se encartam em situações ainda em curso, podem e devem ser tratados de maneira a se lhes reconhecer a significação jurídica que tiveram em face da regra precedente, sem com isto afrontar-se a regra nova ou negar-lhe imediata vigência"190. Quer dizer: ante um prazo de 20, 10 anos não têm a mesma significação que teriam frente a um prazo de 30. Por outro lado, o período já transcorrido deve guardar, com o prazo novo, a mesma relação que guardava com o prazo anterior.

A solução para o problema será verificar o quanto o tempo já transcorrido significava para o sistema. Feito isso, deverá ser calculado - de acordo com a lei nova - o prazo que ainda falta por cumprir. No caso em exemplo: se o beneficiário havia contribuído com 10 de 20 anos, teria cumprido metade do prazo necessário para aquisição do benefício. Com o advento da lei nova, o contribuinte continuará tendo cumprido proporcionalmente metade do prazo necessário para a aquisição do benefício, carecendo da outra metade do prazo novo - ou seja, mais 15 anos de contribuição - para atingir proporcionalmente os 30 anos exigidos pela nova lei.

\footnotetext{
${ }^{190}$ in MELLO, Celso Antonio Bandeira de. Direito adquirido proporcional. Revista Trimestral de Direito Público, São Paulo, n. 36, p. 18, 2001. Rubens Limongi França também já propunha regra de aplicação proporcional dos prazos antigo e novo (in FRANÇA, Rubens Limongi. Direito intertemporal brasileiro: doutrina da irretroatividade das leis e do direito adquirido, cit., p. 468).
} 
É lapidar a explicação de Celso Antônio Bandeira de Mello:

"É dizer: consideram-se os fatos atuais, consoante a significação que lhes atribui o dispositivo atual, e absorvem-se os fatos vencidos, segundo o significado que lhes outorgava a lei do tempo. Em uma palavra: faz-se reconhecimento, não apenas nominal, mas real, de que uma situação foi apanhada por duas normas, de que esteve sob regência de dois preceitos, pois seu caráter continuado - e não instantâneo - levou-a a transitar pelo tempo e ser interceptada por diplomas diferentes, ambos atuantes, cada qual à época de seu respectivo período de vigência, como é natural.

Afinal: aplica-se sempre a lei do tempo. Aos fatos transcorridos, deferemse a significação e expressão que possuíam ao lume da regra sob cujo império se efetivaram. Por não se terem exaurido, entende-se que os eventos remanescentes, em continuação, hão de se consumar e definir segundo critérios do novo diploma. A dizer: fica a globalidade da situação disciplinada pelos paradigmas decorrentes da norma atual, que, entretanto, recebe os fatos pretéritos segundo a qualificação, o valor relativo, que lhes emprestava a norma antiga.

Apliquemos, exempli gratia, estes preceitos exegéticos ao caso da aposentação. Este é o direito que só se completa depois de totalmente perlongada a dilação temporal prevista pela regra concessiva do benefício. De outro lado, é logicamente impossível chegar-se ao seu tempo sem percorrer, passo a passo, todo o itinerário cronológico conducente ao final do prazo. Quando entre o início e o encerramento do prazo para fruição da aposentadoria incidem duas normas que assinalam períodos diversos para o momento aquisitivo, os eventos que se passaram sob a regra antiga têm significações diferentes perante o Direito.

Segue do exposto que, sob o império de uma dada regra, que fixava em tantos anos $(25,30,35$ anos) de serviço o prazo para aposentação de servidor do sexo masculino, cada ano transcorrido tinha, perante o Direito, uma significação relativa (ao todo) perfeitamente identificável, reconhecível, independentemente da circunstância de envolver ou não direito adquirido.

Esta significação a que se aludiu corresponde ao valor, à importância, em síntese, ao relevo, que a ordem normativa atribui ao período de trabalho transcorrido em relação às possibilidades de se implementar a aposentadoria facultativa.

Em termos concretos: sob o império da Constituição de 1946, por exemplo, um ano de serviço correspondia a $1 / 30$ avos do prazo para aposentação do servidor do sexo masculino; 15 anos de serviço correspondiam a 15/30 avos, ou seja, metade do período necessário para aposentação a pedido.

De nenhum modo se contém nesta assertiva, de obviedade inconteste, a afirmação de que o funcionário haveria, por tal razão, adquirido o direito de se aposentar com 30 anos de serviço, se não os houvesse completado e sobreviesse preceito constitucional novo, dilatador do prazo, como viria ocorrer. 
$\mathrm{O}$ asserto que se faz contém em si mesmo nem mais nem menos que a seguinte proposição: cada ano de serviço possui uma significação de direito perante a norma então vigente. Esta significação é a relação entre o período vencido e o período total requerido para que se integralize o direito a se aposentar. A superveniência de outra norma encontra significações já existentes e, dentre elas, esta a que se aludiu. Por força das disposições novas certamente o servidor não poderá se aposentar antes de 35 anos de serviço, mas tais disposições não podem desconstituir o significado jurídico que os 20 anos passados tiveram sob o império da lei do tempo em que transcorreram sem com isto estarem incursas em retroação. Ou seja: se ele tinha, pois, 2/3 do tempo necessário para a aposentação, ele continuará a ter estes $2 / 3$, já agora dos 35 anos que passaram a ser requeridos" ${ }^{\prime 191}$.

Perceba-se que a solução se amolda perfeitamente à regra de que, em geral, a lei possui efeitos imediatos mas não retroativos. Caso a lei nova alterasse a significação do tempo já transcorrido na vigência da lei antiga, teria operado retroativamente, o que só é permitido mediante ressalva expressa. À falta de tal ressalva, a lei deve operar apenas dali em diante, considerando a significação que o tempo teve para a lei anterior ${ }^{192}$.

\subsection{Figuras que se assemelham e possuem a mesma proteção conferida ao direito adquirido}

\subsubsection{O ato jurídico perfeito}

Para o Legislador, ato jurídico perfeito é "o já consumado segundo a lei vigente ao tempo em que se efetuou", conforme se lê no artigo $6^{\circ}, \S 1^{\circ}$, da Lei de Introdução ao Código Civil. Consumado, por sua vez, é "aquelle que já se fez inteiramente effectivo, é um facto acabado, totalmente realisado, e a respeito do qual nada é possivel reclamar senão o respeito ao que já aconteceu e que já produziu os seus effeitos"193, ensina Reynaldo Porchat.

\footnotetext{
${ }^{191}$ in MELLO, Celso Antonio Bandeira de. Direito adquirido proporcional, cit., p. 19.

${ }^{192}$ Consigna-se a ressalva de que, embora aqui se acate a orientação de Celso Antônio Bandeira de Mello, divergimos de uma das conclusões do autor, qual seja, a de que a solução valeria sempre, porque vedada a retroatividade, especialmente a "retroatividade in pejus". Conforme já expusemos, entendemos que o efeito retroativo é permitido desde que seja expresso e não fira direitos adquiridos - o que, repita-se, não se dá com esta ordem de direitos, pois o transcurso parcial do tempo não gera a aquisição de direitos. Nesse contexto, poderia a lei nova estabelecer - desde que de forma expressa - que o sujeito deva cumprir todo o restante do tempo faltante para o novo prazo, retroagindo, sem considerar a significação jurídica do tempo transcorrido durante a vigência da lei anterior (no caso do exemplo, tendo contribuído por 10 anos, o contribuinte deveria vir a contribuir por mais 20, para atingir o prazo de 30). A regra valerá sempre, como quer o douto Professor Celso Antônio Bandeira de Mello, se aprovado o Projeto de Lei n⿳ $4.905 / 95$, que prevê expressamente a regra do direito adquirido proporcional às alterações de prazo produzidas pela lei nova.

${ }^{193}$ in PORCHAT, Reynaldo. op. cit., p. 26-27.
} 
Na definição de Pontes de Miranda, "o ato jurídico perfeito é fato jurídico, que tem o seu momento-ponto, no espaço-tempo, - entrou em algum sistema jurídico, em dado lugar e data" ${ }^{194}$. Complementa José Cretella Jr.: “na expressão 'ato jurídico perfeito’, o vocábulo 'perfeito' tem o sentido de 'acabado', 'que completou todo o ciclo de formação', 'que preencheu todos os requisitos exigidos pela lei'",195.

A proteção conferida ao ato jurídico perfeito tem não só a finalidade de proteger uma das causas geradoras do direito adquirido, mas também os atos completamente exauridos. Ensina J.M. de Carvalho Santos que "a lei quer significar com isso que, não sòmente o direito adquirido, ainda não consumado, fica a salvo de qualquer retroatividade da parte da lei nova, mas que, com muito mais razão, também ficará a salvo o ato jurídico perfeito, correspondente ao direito já consumado" ${ }^{196}$. No mesmo sentido é a lição de José Afonso da Silva, para quem "se o simples direito adquirido (isto é, direito que já integrou o patrimônio mas não foi ainda exercido) é protegido contra a interferência da lei nova, mais ainda o é o direito adquirido já consumado",197.

Assim, um ato que já tenha produzido os seus efeitos não poderá ser atingido por lei posterior. Contudo, da mesma forma que se dá com os direitos adquiridos de maneira complexa, os atos jurídicos perfeitos são protegidos apenas quanto às partes já exauridas, sendo atingidos pela lei nova - desde que não constituam direito adquirido - nas partes ainda não completadas.

Elucidativo é o exemplo de Caramuru Afonso Francisco:

"Questão interessante sobre este assunto se desenvolveu quando da edição da Lei n. 8.009/1990, que tornou impenhorável o imóvel residencial único do devedor, ocasião em que determinou o que denominou de 'cancelamento' das penhoras até então realizadas.

Argumentou-se que tal dispositivo era inconstitucional, porque as penhoras que já haviam sido feitas eram atos jurídicos perfeitos e que não poderiam, pois, sofrer o impacto da lei nova, nos termos do art. $6^{\circ}, \S 1^{\circ}$, da LICC.

Após um início de julgados nesse sentido, os tribunais acabaram por entender que o dispositivo da Lei n. 8.009/1990 não era inconstitucional,

\footnotetext{
${ }^{194}$ in MIRANDA, Francisco Cavalcanti Pontes de. op. cit., p. 114.

${ }^{195}$ in CRETELLA JÚNIOR, José. Comentários à Constituição Brasileira de 1988. Rio de Janeiro: Forense Universitária, 1991. v. 1. p. 458-459.

${ }^{196}$ in SANTOS, J. M. de Carvalho. op. cit., p. 46-47.

${ }^{197}$ in SILVA, José Afonso da. Curso de direito constitucional positivo. 15. ed. rev. atual. nos termos da Reforma Constitucional. São Paulo: Malheiros Ed., 1988. p. 436.
} 
pois a penhora não era um ato jurídico isolado, mas um ato judicial pelo qual um determinado bem do patrimônio do devedor era tornado garantia ao credor que promovia a execução. A penhora, portanto, nada mais era que um requisito para a alienação do bem do devedor para satisfação do credor.

Ora, sendo assim, a partir do momento que a Lei n. 8.009/1990 entrou em vigor, a impenhorabilidade da residência única do devedor implicava na sua inalienabilidade (sic), ou seja, o imóvel residencial único do devedor não poderia mais ser alienado. Deste modo, as alienações judiciais que se fizessem a partir da Lei n. 8.008/1990 não poderiam envolver o imóvel residencial único de devedores. A penhora, assim, não era um ato jurídico perfeito, mas um requisito para que se fizesse a alienação judicial, alienação que seria posterior à edição da Lei n. 8.009/1990.

Estávamos, pois, diante de um 'caso pendente', já sob o império da lei nova. A disposição da Lei n. 8.009/1990, que 'cancelava' as penhoras, portanto, não era senão uma conseqüência lógica do fato de que pairava, sobre os processos de execução em curso, um 'caso pendente', a total impossibilidade de se promover a alienação dos imóveis residenciais únicos de devedores que, desde a entrada em vigor da Lei n. 8.009/1990, haviam se tornado inalienáveis" ${ }^{, 198}$.

O exemplo demonstra que a lei nova pode, no presente, atingir fato nascido antes de seu advento, desde que este não constitua direito adquirido, ato jurídico perfeito ou coisa julgada. Com relação a este ponto, pedimos vênia para fazer remissão ao item no qual tratamos do atual estado da matéria na Itália (item 1.4.2), no âmbito do qual tecemos considerações acerca da teoria dos fatos consumados.

\subsubsection{A coisa julgada}

O Legislador conceituou a coisa julgada nos artigos $6^{\circ}, \S 3^{\circ}$, da Lei de Introdução ao Código Civil, e 467 do Código de Processo Civil:

“Art. $6^{\circ} .(\ldots)$

$(\ldots)$

$\S 3^{\circ}$. Chama-se coisa julgada ou caso julgado a decisão judicial de que já não caiba recurso".

\footnotetext{
${ }^{198}$ in FRANCISCO, Caramuru Afonso. Lei de Introdução ao Código Civil comentada (Decreto-Lei n. 4.657,
} de 4.9.1942). São Paulo: Juarez de Oliveira, 2005. p. 68. 
"Art. 467. Denomina-se coisa julgada material a eficácia, que torna imutável e indiscutível a sentença, não mais sujeita a recurso ordinário ou extraordinário".

Rubens Limongi França já aplaudia a proposta de redação contida no Anteprojeto de Código de Processo Civil, em cujo artigo 507 se lia ser a coisa julgada "a qualidade, que torna imutável e indiscutível o efeito da sentença, não mais sujeita a recursos ordinários e extraordinários" ${ }^{\prime 199}$.

A esse respeito, Araken de Assis comenta que "nem todo provimento se revela idôneo a revestir-se dessa singular eficácia, mas tão-só a 'sentença' (...)”200. Daí propor conceito segundo o qual se considera coisa julgada "o atributo do provimento judicial que, julgando o mérito, nas hipóteses arroladas no art. 269, não se mostra mais suscetível de recurso, no processo em que há função de cognição preponderante"201.

A proteção à coisa julgada é de imensa importância à estabilidade das relações jurídicas $^{202}$. Conforme ressalta Cândido Rangel Dinamarco,

\begin{abstract}
"sendo um elemento imunizador dos efeitos que a sentença projeta para fora do processo e sobre a vida exterior dos litigantes, sua utilidade consiste em assegurar estabilidade a esses efeitos, impedindo que voltem a ser questionados depois de definitivamente estabelecidos por sentença não mais sujeita a recurso"203.
\end{abstract}

Se acertada é a proteção ao direito adquirido e ao ato jurídico perfeito, ainda mais é o respeito à atividade jurisdicional. Afinal, "o interêsse social exige que as decisões dos

\footnotetext{
${ }^{199}$ in FRANÇA, Rubens Limongi. Direito intertemporal brasileiro: doutrina da irretroatividade das leis e do direito adquirido, cit., p. 440.

${ }^{200}$ in ASSIS, Araken de. Eficácia da coisa julgada inconstitucional. Revista Dialética de Direito Processual, São Paulo, v. 4, p. 10, 2003. p. 10. Na seqüência, o autor afirmava que sentença era o ato que "conforme o art. $162, \S 1^{\circ}$, do CPC (...) põe fim ao processo". Suprimimos a passagem em razão da alteração do artigo $162, \S 1^{\circ}$, do Código de Processo Civil, pela Lei $\mathrm{n}^{\mathrm{o}} 11.232 / 2005$, embora pareça-nos que o conceito de sentença não tenha se alterado substancialmente.

${ }^{201}$ Id. Ibid.

${ }^{202} \mathrm{O}$ autor afirma ainda que "para as atividades do Poder Judiciário, a manifestação do princípio do Estado democrático de direito ocorre por intermédio do instituto da coisa julgada. Em outras palavras, a coisa julgada é elemento de existência do estado democrático de direito" (in NERY JÚNIOR, Nelson. Coisa julgada e o Estado democrático de direito. Revista Forense, Rio de Janeiro, v. 100, n. 375, p. 142-143, set./out. 2004 - texto este ao qual voltaremos ao traçar paralelo entre os limites da proteção do direito adquirido e as teses da relativização da coisa julgada - item 4.2.3).

${ }^{203}$ in DINAMARCO, Cândido Rangel. Relativizar a coisa julgada material. Revista de Processo, São Paulo, v. 28, n. 109, p. 9, jan./mar. 2003.
} 
tribunais sejam consideradas como a expressão da verdade, pois, de outra forma, desapareceria a confiança na Justiça e, desprestigiada a Justiça, abalados ficariam os alicerces em que se assentam a estabilidade e a ordem social”, conforme frisa J. M. de Carvalho Santos ${ }^{204}$.

\title{
3.5. Figuras que se assemelham mas não possuem a mesma proteção conferida ao direito adquirido
}

\subsubsection{As expectativas de direito}

A noção de expectativa de direito deflui contrario sensu do conceito de direito adquirido. Nas palavras de Rubens Limongi França, "a diferença entre Expectativa de Direito e Direito Adquirido está na existência, em relação a êste, do fato aquisitivo específico, já configurado por completo" ${ }^{, 205}$.

Como ensina Carlos Francesco Gabba,

\begin{abstract}
"Qualquer que seja a índole dos fatos mediante os quais se adquirem dos direitos, é princípio geral que os fatos aquisitivos devem se verificar por inteiro antes que se possa dizer adquiridos os direitos que se destinam a produzir. Não há dúvida, por exemplo, que, enquanto o prazo prescricional não decorre por inteiro, não há direito adquirido por meio da prescrição, e que, antes da morte do possuidor atual, não há direito adquirido de o fideicomissário vir a suceder, mas apenas expectativa" ${ }^{206}$.
\end{abstract}

Enquanto o direito adquirido integra o patrimônio do titular, a expectativa depende de acontecimento externo para que venha a sê-lo. É um não-direito-ainda, com as características de que: (1) para que seja expectativa, deve independer da vontade do sujeito, senão não seria esperança, mas faculdade não exercida; (2) para que seja de direito, deve objetivar a aquisição de um direito, pois senão tal expectativa não seria jurídica, mas mero capricho do

\footnotetext{
${ }^{204}$ in SANTOS, J. M. de Carvalho. op. cit., p. 47.

${ }^{205}$ in FRANÇA, Rubens Limongi. Direito intertemporal brasileiro: doutrina da irretroatividade das leis e do direito adquirido, cit., p. 445.

${ }^{206}$ GABBA, Carlos Francesco. op. cit., p. 228. Tradução livre de: “Qualunque sia l'indole dei fatti mediante $i$ quali si acquistano $i$ diritti, è principio generale che i fatti acquisitivi devonsi essere verificati per intiero, prima che si possano dire acquistati i diritti che quei fatti sono destinati a produrre. Non v'ha dubbio, per esempio, che, fintantochè il termine prescrizionale non è decorso per intiero, non vi ha diritto acquistato mediante la prescrizione, e che, prima della morte del possessore attuale, non ha il primo chiamato al fedecommesso diritto acquisito di succedere, che una legge nuova non possa togliere, ma soltanto aspettativa".
} 
ser. Logo, expectativa de direito pode ser conceituada como um vir-a-ser-direito independente da vontade daquele que espera.

De fato, o esperar será sempre passivo; quem pode agir e não age não se pode dizer à espera. Por sua vez, não fosse jurídico o objeto da esperança, estar-se-ia diante de fato estranho à ordem jurídica, ou, noutros termos, de fatores psicológicos que não interessam ao direito intertemporal. Por exemplo, o desejo de ser feliz pouco importa ao direito intertemporal. A felicidade é desejo dos homens, mas não do mundo jurídico. É apenas para o poeta dizer que todos têm direito a ser feliz.

Nas palavras de Reynaldo Porchat, expectativa de direito é a "esperança de um direito que, pela ordem natural das cousas, e de accordo com uma legislação existente, entrará provavelmente para o patrimônio de um individuo quando se realise um acontecimento previsto" 207 .

Exemplos de Carlos Maximiliano reforçam o conceito: "sucessão, quando existe apenas um testamento ${ }^{208}$; dote, quando só se lavrou a escritura respectiva; para haver direito adquirido, se faz mister, na primeira hipótese, advir o óbito do disponente; na segunda, realizar-se o casamento da pessoa beneficiada" ${ }^{209}$. Também de valia o exemplo trazido por Sérgio Pinto Martins: "expectativa de direito ocorre quando o beneficiário ainda não reuniu todas as condições para adquirir o direito, que não faz parte do seu patrimônio jurídico, nem pode ser exercitado de imediato. Na expectativa de direito há a esperança, a

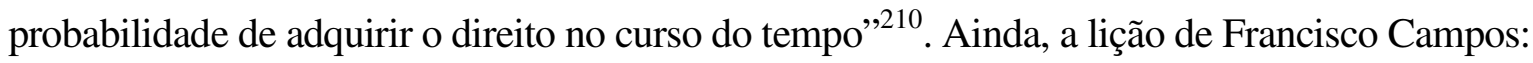

"O direito à aposentadoria só se constitui, portanto, ao fim do prazo ou de duração fixada pela lei. No curso do prazo, portanto, poderá a lei modificar, sem ofensa a direitos adquiridos, ou a atos jurídicos perfeitos, as condições da aposentadoria, não sòmente quanto às suas vantagens, mas também quanto ao tempo exigido para a sua concessão. O fato, que é um fato continuado, só se terá por consumado no término final do prazo. Durante o curso dêste, $\mathrm{o}$ ato jurídico, de que decorre o direito à aposentadoria, está em formação; não é, assim, um ato jurídico perfeito ou já consumado. É certo que o tempo já passado sob a vigência de uma lei é um fato consumado, cada fração do tempo não tem, porém, um valor jurídico próprio ou não é apta, por si só, a gerar efeitos jurídicos. O efeito jurídico só decorre da cumulação de tôdas as frações e, portanto, se

\footnotetext{
${ }^{207}$ in PORCHAT, Reynaldo. op. cit., p. 30.

${ }^{208}$ Ressalva seja feita ao fato de que, com relação à forma do testamento, esta constitui ato jurídico perfeito, inalterável pela lei nova (item 5.7.3).

${ }^{209}$ in MAXIMILIANO, Carlos. op. cit., p. 45.

${ }^{210}$ in MARTINS, Sérgio Pinto. Direito adquirido e reforma previdenciária. Revista de Previdência Social, São Paulo, ano 23, n. 222, p. 454, 1999.
} 
configura precisamente no momento em que o prazo se ultima. Durante o curso do prazo, a lei nova poderá fazer variar a duração dêste ou modificar os efeitos jurídicos futuros que a lei anterior autorizava os interessados a esperar ao fim do prazo. Durante o curso do prazo, a lei nova não destruiria nenhum ato jurídico perfeito ou ofenderia um direito adquirido; teria apenas frustrado uma expectativa de direito, que não goza de nenhuma imunidade contra a ação de novo estatuto jurídico que possa vir a contrariá-la",211.

Confira-se, por fim, a lição de Rubens Limongi França:

"Examinemos um caso de Expectativa, qual seria o de uma lei que mudasse a ordem da vocação hereditária, de tal forma que o que era contemplado como herdeiro pela lei antiga tivesse deixado de sê-lo conforme a lei nova. É princípio assentado no Direito Intertemporal que, em se tratando de mera Expectativa, é o nôvo estatuto o aplicável. Ora, a Faculdade outorgada pela ordem legal da vocação hereditária é puramente abstrata, uma vez que não tenha preenchido o requisito da morte do de cujus. Ergo, a lei atuante é a mais recente" ${ }^{, 212}$.

A identificação da expectativa de direito é de grande importância, pois, assim como algumas faculdades jurídicas, não goza de proteção contra o efeito imediato, submetendose aos ditames da lei nova.

\subsubsection{As faculdades jurídicas}

Faculdade jurídica, segundo Reynaldo Porchat, é "a simples capacidade, não exercitada, de praticar actos jurídicos; é um direito que a lei reconhece, mas que nunca foi posto em prática, do qual ainda não foi feito uso pela pessoa de quem se trata, como, por exemplo, a faculdade de contrahir casamento, ou a faculdade de testar",213.

\section{Como ensina Carlos Francesco Gabba,}

"Todas vez que afirmamos a concreta existência de um direito, esta nossa afirmação pressupõe: $1^{\circ}$ a existência de um fato, o qual ou em virtude do qual decorre o direito; $2^{\circ}$ a existência de uma lei, que daquele fato faz surgir o direito. Antes que em concreto surja o direito, esse se encontra em estado

\footnotetext{
${ }^{211}$ in CAMPOS, Francisco. Direito civil. Rio de Janeiro: Freitas Bastos, 1956. p. 276-277.

${ }^{212}$ in FRANÇA, Rubens Limongi. Direito intertemporal brasileiro: doutrina da irretroatividade das leis e do direito adquirido, cit., p. 511.

${ }^{213}$ in PORCHAT, Reynaldo. op. cit., p. 30.
} 
de mera possibilidade em uma lei, a qual contempla um certo modo de agir ou de ser do indivíduo, atribuindo a este uma dada faculdade jurídica"214.

Bem se vê que, assim como as expectativas de direito, as faculdades jurídicas também são um direito em potencial, mas delas diferem porque o seu exercício depende da vontade do agente, e não de evento futuro externo. São um vir-a-ser-direito dependente da vontade daquele a que se faculta.

J.M. Othon Sidou diferencia as expectativas de direito das faculdades jurídicas nos seguintes termos:

\begin{abstract}
"a expectativa de direito tem por único pressuposto que o seu resultado, ou concreção, dependa de uma vontade estranha ao titular e só por isto não se concretiza. A faculdade de direito dependente apenas da vontade do titular, para transformar-se de situação jurídica abstrata em situação jurídica concreta" ${ }^{215}$.
\end{abstract}

Observa ainda Reynaldo Porchat que "o conceito de espectativa está para o de faculdade, como o conceito de probabilidade está para o de possibilidade"216.

A identificação das faculdades jurídicas é de grande importância porque estas não recebem a proteção constitucional do direito adquirido. Conforme já referido anteriormente, não há direito adquirido a adquirir direitos, pois não existe direito adquirido ao direito objetivo. Como ensina Elival da Silva Ramos, "o princípio de que não há direito adquirido ao direito objetivo, abstratamente considerado, está por trás da distinção entre aquele e as faculdades legais $(\ldots)^{, 217}$.

Assim, por exemplo, não existirá direito adquirido a regime jurídico. A esse respeito, julgado relatado pelo Ministro Eros Grau:

\footnotetext{
${ }^{214}$ GABBA, Carlos Francesco. op. cit., p. 194. Tradução livre de: "Tutte le volte che noi affermiamo la concreta esistenza di un diritto, questa nostra affermazione ha due oggetti: $1^{\circ}$ l'esistenza di un fatto, dal quale o in virtù del quale noi riteniamo sia sorto il diritto; $2^{\circ}$ l'esistenza di una legge, la quale da quel fatto fa provenire il diritto. Prima che in concreto sorga il diritto, esso trovase in stato di mera possibilità in una legge, la quale contempla un dato modo di agire o di essere degli individui, e nell'ipotesi del medesimo attribuisce a questi una data facoltà giuridica".

${ }^{215}$ in SIDOU, J. M. Othon. A "existência" da lei (regras de direito intertemporal). In: MARTINS, Ives Gandra da Silva (Coord.). As vertentes do direito constitucional contemporâneo. Rio de Janeiro: América Jurídica, 2002. p. 330.

${ }^{216}$ in PORCHAT, Reynaldo. op. cit., p. 30-31.

${ }^{217}$ in RAMOS, Elival da Silva. op. cit., p. 184.
} 
"Se o crédito se constituiu após o advento do referido texto normativo, é fora de dúvida que a sua extinção, mediante compensação, ou por outro qualquer meio, há de processar-se pelo regime nele estabelecido e não pelo da lei anterior, uma vez que aplicável, no caso, o princípio segundo o qual não há direito adquirido a regime jurídico. Agravo regimental a que se nega provimento"218.

Pela mesma razão, não há direito adquirido a proibições ou deveres impostos pela

lei.

Saber diferenciar os direitos adquiridos das faculdades jurídicas permite resolver grande parte dos problemas de direito intertemporal, como se verá, por exemplo, nos itens $5.3 .4,5.5,5.5 .1,5.6,5.6 .1,5.6 .4$ e $5.6 .6^{219}$.

${ }^{218}$ STF, $1^{\text {a }}$ Turma, Ag. Reg. no Ag. Inst. no 511024/PR, Rel. Min. Eros Grau, j. 14.6.2005, v.u.

${ }^{219}$ Rubens Limongi França divide as faculdades jurídicas em Faculdades de Direito Natural e Faculdades de Direito Positivo. Dentre estas, diferencia as faculdades concretas das abstratas, subdividido-as em faculdades abstratas dependentes de requisito e faculdades abstratas dependentes de fato aquisitivo específico. Eis sua explicação:

"São elas de duas naturezas fundamentais: de Direito natural e de Direito Positivo.

As de Direito Positivo se subdividem em abstratas e concretas. Por sua vez as abstratas podem ser dependentes de requisito ou dependentes de fato aquisitivo específico, para se concretizarem.

Faculdades de Direito Natural são as que não estão previstas em lei ou outra forma de expressão do Direito, mas que o sujeito possui em razão da Natureza das Coisas. Assim, o direito à imagem, o direito ao nome, o direito ao recato, concernem a efetivas Faculdades Jurídicas, muito embora entre nós o Sistema não as tenha previsto, ou apenas o tenha feito parcialmente. Por outro lado, não obstante, elas são jurídicas, porque se entendem com a questão do meu e do seu.

Faculdades de Direito Positivo são as correspondente a normas previstas no Sistema Jurídico, principalmente na Lei. São de modo geral, as facultas agendi, definidas pelo complexo das normas agendi.

Faculdades abstratas são aquelas que, fundando-se no Sistema, ainda não passaram para o patrimônio moral ou material do sujeito.

Faculdade abstrata dependente de requisito é aquela cujo direito tem como fato aquisitivo específico a própria Lei, mas não passou para o patrimônio do sujeito, em virtude da falta de algum elemento acidental que a mesma lei exige.

Faculdade abstrata dependente de fato aquisitivo específico é aquela que, tendo como causa eficiente principal e direta um fato ou ato exterior à Lei, ainda não passou para o patrimônio do sujeito em virtude da carência dessa causa ou da falta de sua complementação.

Faculdade jurídica concreta é aquela que já passou para o patrimônio moral ou material do sujeito, em virtude quer da atuação direta e perfeita da própria lei, quer do preenchimento de algum requisito legal acidental, quer da incidência e perfeição de fato aquisitivo específico.

De onde as seguintes conclusões a respeito das Faculdades Jurídicas:

a) As Expectativas de Direito correspondem às Faculdades abstratas, tanto dependentes de requisito como de fato aquisitivo específico.

b) As Faculdades concretas estão, tôdas elas, incluídas no conceito fundamental de Direito Adquirido.

c) As Faculdades de Direito Natural, embora, numa lucubração teórica, também se possam dividir em abstratas e concretas, não se inserem, sob nenhum aspecto, na noção de Direito Adquirido.

(in FRANÇA, Rubens Limongi. Direito intertemporal brasileiro: doutrina da irretroatividade das leis e do direito adquirido, cit., p. 449-450).

Quando falamos em faculdades jurídicas, estamos a nos referir às faculdades abstratas dependentes de fato aquisitivo específico, a que alude o mestre. Quando nos referimos às expectativas de direito, referimo-nos às faculdades abstratas dependentes de requisito. E, por fim e por óbvio, quando falamos em direito adquirido nos voltamos à idéia de faculdade concreta. 


\title{
3.5.3. As instituições jurídicas
}

Instituições jurídicas são relações-tipo abstratas criadas por lei. Por exemplo, a escravidão constituía a relação-tipo do direito de ter escravos; a enfiteuse é a relação-tipo da qual decorre o direito de constituir enfiteuses; o contrato é a relação-tipo da qual decorre o direito de contratar. Esta a lição de Luiz da Cunha Gonçalves:

\begin{abstract}
“(...) o legislador, no exercício da sua missão de estabelecer a ordem social, institui ou regula relações jurídicas abstratas, relações-tipo, que põe à disposição dos que delas se queiram utilizar, para a satisfação dos seus interesses. Estas relações-tipo são designadas por instituições jurídicas.

Podemos também dizer que a instituição jurídica é o conjunto das normas ou regras de direito que se interpenetram e constituem um todo orgânico, que abrange uma série de relações derivadas de um facto fundamental e característico (...),220.
\end{abstract}

Como decorrem da lei, as instituições jurídicas duram até que outra lei as extinga, tendo pois duração perpétua; não só, algumas delas dão azo a direitos de duração perpétua, como é o caso da propriedade. Por exemplo, a escravidão seria perpétua não houvesse sido extinta pela Lei Áurea; a faculdade de constituir enfiteuse seria perpétua se o Código Civil de 2002 não a tivesse proibido.

Com a evolução do Direito, o Legislador por vezes extingue instituições jurídicas, como ocorreu e.g. com a escravidão e a enfiteuse. Tal fato inevitavelmente gera conflito de direito intertemporal, pois, de um lado, haverá a necessidade social, consubstanciada na lei nova e extintiva, e, de outro, o direito adquirido do sujeito que tiver se valido da instituição jurídica extinta. Por exemplo, o fim da escravidão implicou conflito entre a Lei Áurea e o direito dos senhores de escravos; o fim da enfiteuse teria causado semelhante conflito, não houvesse sido previsto dispositivo transitório protegendo as enfiteuses constituídas antes de 11 de janeiro de 2003, até sua extinção (artigo 2.038).

Para resolver esse conflito, muitos autores sustentam que não haveria direito adquirido às instituições jurídicas, e por essa razão - a absoluta ausência de direitos a serem tutelados

\footnotetext{
${ }^{220}$ in GONÇALVES, Luiz da Cunha. Princípios de direito civil luso-brasileiro. São Paulo: Max Limonad, 1951. v. 1, p. 64.
} 
- a lei nova poderia incidir desde logo sobre todas as relações em curso. Nesse sentido é a opinião de Carlos Maximiliano:

"Não há direito adquirido no tocante a instituições, ou institutos jurídicos. Aplica-se logo, não só a lei abolitiva, mas também a que, sem os eliminar, lhes modifica essencialmente a natureza. Em nenhuma hipótese granja acolhida qualquer alegação de retroatividade, posto que, às vezes, tais institutos envolvam certas vantagens patrimoniais que, por eqüidade, o diploma último ressalve ou mande indenizar",221.

Contudo, embora não haja direito adquirido às instituições jurídicas abstratamente consideradas, não se pode negar o direito concreto do sujeito que tenha se valido daquela determinada relação-tipo. Por exemplo, o senhor não teria direito de comprar novos escravos depois da abolição, mas continuaria a ter direito sobre os escravos que já possuísse; com o Código Civil de 2002, proibiu-se a constituição de novas enfiteuses, mas o direito dos senhorios e enfiteutas deveria ser protegido contra o advento da lei nova - e acabou sendo, em razão de disposição transitória (item 5.5.1).

A esse respeito, já advertia Carlos Francesco Gabba:

"os institutos jurídicos perpétuos não são matéria de um verdadeiro e próprio direito adquirido (...). Um verdadeiro direito adquirido, respeitável como qualquer outro, é aquele que, em razão de fato idôneo, torna-se direito subjetivo concreto decorrente do direito contido em um desses institutos"222.

Entretanto, não queremos dizer que as leis que extinguem instituições jurídicas não tenham efeito imediato e retroativo, como de fato têm. Tais leis atingem as relações pretéritas, inclusive os direitos adquiridos, porque só assim podem ter efetividade frente ao caráter perpétuo das instituições jurídicas e de alguns direitos delas decorrentes. Do contrário, tais normas só ganhariam aplicação depois de muitas décadas, com a morte dos titulares dos direitos, e os escravos teriam existido até meados do Século XX.

\footnotetext{
${ }^{221}$ in MAXIMILIANO, Carlos. op. cit., p. 62.

${ }^{222}$ in GABBA, Carlos Francesco. op. cit., p. 354. Tradução livre de "gli istituti giuridici perpetui non sono materia di un vero e proprio diritto acquisito (...) non già considerati in relazione a determinati individui che attualmente ne fruincono. Un vero diritto acquisito, rispettabile al pari di qualunque altro, ci sembra quello di chi, in virtù di un idoneo fatto acquisitivo, à diventato subbieto concreto del diritto o dei diritti racchiusi in uno di tali istituti".
} 
A nosso ver, trata-se de exceção à regra da proteção dos direitos adquiridos, o que não a infirma pois o direito intertemporal não poderia impedir, por completo, a aplicação de determinadas normas jurídicas - o que fatalmente ocorreria se, dada sua perpetuidade, as instituições jurídicas e os direitos delas decorrentes não pudessem ser extintos pela lei nova.

Esta já era a opinião de Reynaldo Porchat:

“(...) os progressos da civilisação, impulsionando o aperfeiçoamento do direito, têm determinado a necessidade de abolir os institutos jurídicos, que não se adaptam mais ás novas condições, á índole, aos costumes do povo. Ao mesmo tempo, não é possivel deixar de reconhecer que a abolição desses institutos produz effeitos directos sobre o patrimônio dos indivíduos, constituindo um verdadeiro ataque aos direitos adquiridos.

Ora, se, de conformidade com o principio fundamental da theoria da retroactividade, as leis novas não podem retroahir o seu effeito de modo a lesar direitos adquiridos, segue-se que, uma vez resalvados da acção retroactiva da nova lei esses direitos, e sendo elles de natureza perpetua, como é o direito do emphytuta sobre o immovel enphyteuticado, ou o do senhor sobre o escravo, a lei abolitiva não poderia realisar o seu fim, seria uma lei inefficaz.

Á vista disso, alguns autores esforçam-se por demonstrar que semelhantes leis têm effeito retroactivo completo, levando de vencida os direitos adquiridos; e assim deve ser, dizem elles, porque, desde que seja reconhecida a necessidade de abolir institutos de natureza perpetua, por não estarem mais de accôrdo com as idéias e as condições da sociedade civil, é que esses institutos não têm mais legitimidade perante os princípios superiores do direito, da justiça e da razão. E em nome desses princípios, póde ser considerada como justa, nesses casos excepcionaes, a retroactividade com offensa aos direitos adquiridos. No caso em que a lei positiva é, de facto, a negação do direito e da justiça, dizia o notável professor Conselheiro Justino de Andrade, a lei nova, que a revoga, tem effeito retroactivo, em face de um princípio irrefragável, que é o seguinte: - 'as leis que restabelecem o direito natureal e reparam os direitos imprescriptiveis da humanidade, devem receber immediata applicação por todos os meios possiveis.

Para outros, a inviolabilidade dos direitos adquiridos é um dogma tão respeitável, que, mesmo nesses casos figurados, não é admissível que a lei nova os extinga sem que os indivíduos prejuicados sejam devidamente recompensados pelo Estado com a competente indemnisação pelo damno que soffrerem.

No Brasil, quando foi abolida a escravidão, pela lei de 13 de maio de 1888 , os poderes públicos entenderam do primeiro modo, a despeito do preceito constitucional vigente, achando justa a retroactividade da lei para o effeito de extinguir, como extinguiu, sem indemnisação alguma, os direitos adquiridos dos senhores sobre os escravos, que constituíam uma propriedade garantida pelas leis. 
$\mathrm{Na}$ Inglaterra, quando foi abolida a escravidão nas possessões inglezas, entendeu-se do segundo modo, que está mais de acordo com o rigor do direito, despendendo o governo inglez avultadas sommas para indemnisar os damnos causados aos senhores dos escravos.

O certo é que, a despeito das divergencias quanto aos dever de indemnisação, que nos parece um consectario do respeito aos direitos individuaes, todos concordam em que as leis abolitivas de institutos de duração perpetua necessitam, para a realisação do seu fim, do mais amplo effeito retroactivo, extinguindo mesmo os direito adquiridos.

É, segundo pensamos, uma excepção á doutrina exposta, excepção justificada pela necessidade juridica que dictou a nova lei" ${ }^{223}$.

Esse entendimento é referendado pela quase totalidade dos autores, conforme aponta Wilson de Souza Campos Batalha ${ }^{224}$.

No entanto, isso não impede que, por uma questão de política legislativa recomendável, na generalidade dos casos -, a lei nova determine o pagamento de indenização pela extinção do direito adquirido. Como se nota da transcrição anterior, essa foi a opção adotada pelo Legislador inglês, quando da abolição da escravatura naquele país, diferentemente do que se deu no Brasil.

Daí se concluir que a lei que extingue instituições jurídicas ou direitos perpétuos tem efeito imediato e retroativo, inclusive sobre direitos adquiridos, podendo o Legislador, no entanto - por uma questão de política legislativa -, conferir indenização sobre o conteúdo patrimonial do direito extinto.

\footnotetext{
${ }^{223}$ in PORCHAT, Reynaldo. op. cit., p. 45-48.

${ }^{224}$ in BATALHA, Wilson de Souza Campos. Direito intertemporal. Rio de Janeiro: Forense, 1980. p. 283287.
} 


\section{QUARTA PARTE. OS LIMITES DA PROTEÇÃO DO DIREITO ADQUIRIDO}

\subsection{Breve apanhado histórico}

Embora a investigação histórica não seja objeto deste trabalho - o que já foi feito com insuperável maestria por Rubens Limongi França -, é interessante anotar que, ao longo dos tempos, a proteção do direito adquirido encontrou limites em diversos princípios das civilizações. Se de um lado a idéia de direito adquirido tem servido há séculos de base para a segurança das relações jurídicas, também certo é que valores outros têm sido causa para afastar sua proteção. Como qualquer outro princípio, o da irretroatividade não é nem nunca foi absoluto.

Na Grécia, a noção de irretroatividade erigiu-se embrionariamente sobre a idéia de justiça. Fosse justa, a lei antiga continuaria a ser aplicada. Se injusta, daria lugar à lei nova. Conforme ensina Rubens Limongi França, "os Gregos tinham a noção da revogação da lei antiga pela nova; a lei antiga podia permanecer se considerada justa (...),225.

Orientação semelhante parece ter existido no direito romano pré-clássico. Embora em regra devesse regular apenas os fatos posteriores, a lei nova deveria atingir os fatos passados que fossem nefastos ou criminosos. De acordo com a reprodução de Rubens Limongi França, "nem por meio de alguma lei se abrange o tempo passado, a não ser com relação a fatos tais que, por sua natureza criminosa e nefasta, devem ser reprimidos, ainda que lei não houvesse",226.

Interessante, também, regra do direito justinianeu, de que os juros exorbitantes, mesmo os já contratados, devem ser ajustados a patamares menores, de acordo com lei posterior, impedindo-se a usura. Rubens Limongi França colaciona à sua obra texto de autêntica de Justiniano na qual se lê:

"ordenamos que se corrija a má interpretação que se tem dado à constituição sôbre a usura; assim, determinamos que, aquêles que, antes daquela sanção, estipularem juros maiores, os reduzam a partir da

\footnotetext{
${ }^{225}$ in FRANÇA, Rubens Limongi. Direito intertemporal brasileiro: doutrina da irretroatividade das leis e do direito adquirido, cit., p. 34.

${ }^{226}$ Id. Ibid., p. 44.
} 
publicação da mesma; de modo que o que concerne ao tempo anterior a essa lei seja cobrado de acôrdo com o que se estipulou"227.

No direito intermédio, o Código Visigótico viria a dispor sobre a regra do efeito imediato, protegendo os fatos consumados "salvo justa novidade". Rubens Limongi França transcreve trecho que confirma essa afirmação:

"Determinamos que todo e qualquer pleito, já começado e ainda não terminado, se regule por estas leis. Entretanto, as causas já legalmente resolvidas, antes de emendarmos estas leis, isto é, resolvidas de acôrdo com as leis do passado, de antes do primeiro ano do nosso reinado, não permitimos sejam ressuscitadas. Mas se uma justa novidade das causas o exigir, o príncipe tem o poder de emendar as leis, que tenham pleníssimo vigor, do mesmo modo que as presentes" 228 .

Também durante o direito intermédio se viu disposição que merece ser reavivada, de que o que não vale no início não convalesce com o tempo - tal como se dá com certos direitos apenas aparentemente adquiridos, mas que afrontam princípios e não merecem, pois, a proteção contra o advento da lei nova (o que sustentamos no item 4.2.4). É o que consta de trecho dos Libri Feudorum, segundo nos informa Rubens Limongi França:

"Sôbre o assunto, o imperador Lotário promulgou uma lei prevendo apenas para o futuro. Nós, entretanto, tendo em vista a maior utilidade do reino, não só para o futuro, mas ainda em relação às alienações ilícitas já perpetradas, cassamos com a presente sanção, tornando írritas, sem que se considere prescrição de qualquer tempo: porque, o que de início não vale valuit, tractu temporis convalescere non debet ${ }^{, 229}$.

Ainda durante o direito intermédio podem ser lidas disposições que denotam uma proteção apenas relativa ao direito adquirido. Por exemplo, em Decretal de Gergório IX lêse que não pode existir proteção contra a lei nova quando, em razão da injustiça do pleito, não tenha havido a perfeita formação do direito (conforme sustentamos no item 4.2.4). Traznos o seguinte texto Rubens Limongi França:

\footnotetext{
${ }^{227}$ FRANÇA, Rubens Limongi. Direito intertemporal brasileiro: doutrina da irretroatividade das leis e do direito adquirido, cit., p. 61-62.

${ }^{228}$ Id. Ibid., p. 78.

${ }^{229}$ Id. Ibid., p. 88.
} 
"editamos (que estas disposições) se estendam, não às coisas passadas, mas tão-sòmente às futuras, porque é assente que as leis e constituições dão forma aos negócios futuros e não retroagem aos fatos passados, a menos que nelas se cuide expressamente das coisas passadas.

A êste repeito (...) respondemos que, tanto os que extorquiram usuras antes como depois do nosso interdito, estão obrigados, sob pena que estatuímos no concílio, a restituí-las àqueles a quem extorquiram ou aos seus herdeiros, ou, se não tiverem sobreviventes, a dá-las aos pobres...

As posses, com efeito, que provieram das usuras, devem ser vendidas, e o preço das mesmas deve ser devolvidas àqueles de quem as usuras foram extorquidas...

\section{$(\ldots)$}

... não só aos negócios futuros, como também aos passados e ainda aos pendentes se já isto estendido...

... tem lugar a constituição supradita, a fim de que tôdas as graças, dêste modo, por cuja razão não havia processo para colação, e assim, por consequiência, não existia, por parte dos impetrantes, direito adquirido sôbre a coisa, se entendam totalmente revogadas" ${ }^{\text {,230. }}$.

Segundo informa Rubens Limongi França, a doutrina do direito intermédio foi condensada por Felinus Sandaeus, concluindo este que o período abraçara a regra do efeito imediato, mas com algumas exceções, notadamente a de que a lei nova não atinge o passado "se se trata de fato pretérito que se completa com fato futuro que a nova lei compreenda, a não ser que o fato pretérito, em virtude disso, sofra alguma coisa, ou que a lei conduza a algo excessivamente duro",231.

A fase científica do direito intertemporal também é permeada de princípios que mitigam o da irretroatividade. Ao longo de mais de quatrocentas páginas, Rubens Limongi França cita diversos autores que abraçam este entendimento - de que a proteção contra a lei nova cede lugar quando confrontada com certos outros princípios.

Também de relevo é a dicotomia desenhada por Patrice Level entre aplicação imediata da lei e norma de ordem pública ${ }^{232}$, o que foi empreendido por diversos outros autores, tais como Henry de Page ${ }^{233}$, Josserand ${ }^{234}$ e Alberto Dominguez ${ }^{235}$. Igual orientação teria sido

\footnotetext{
${ }^{230}$ FRANÇA, Rubens Limongi. Direito intertemporal brasileiro: doutrina da irretroatividade das leis e do direito adquirido, cit., p. 90-92.

${ }^{231}$ Id. Ibid., p. 100.

${ }^{232}$ Id. Ibid., p. 173.

${ }^{233}$ Id. Ibid., p. 205.

${ }^{234}$ Id. Ibid., p. 225.

${ }^{235}$ Id. Ibid., p. 235-236.
} 
observada na formação do direito luso-brasileiro, como por exemplo nas Ordenações Afonsinas $^{236}$, Manoelinas ${ }^{237}$ e Filipinas ${ }^{238}$, bem como na doutrina de Carlos de Carvalho ${ }^{239}$, Lafayette $^{240}$, Spencer Vampré ${ }^{241}$, Tito Prates ${ }^{242}$, Washington de Barros Monteiro ${ }^{243}$, Vicente Ráo $^{244}$, Rui Barbosa ${ }^{245}$ e do próprio mestre Rubens Limongi França ${ }^{246}$.

Ao longo da história, foram buscados ainda outros critérios de ponderação do princípio da irretroatividade, como por exemplo o de Pacchioni, para quem a lei poderia retroagir em prol da solidariedade social ${ }^{247}$.

Interessa-nos é que fique assentado ser da tradição do direito intertemporal não conferir interpretação aguda ao princípio da irretroatividade, vislumbrando-se limites à proteção do direito adquirido.

\subsection{Critérios para o estabelecimento dos limites da proteção do direito adquirido}

\subsubsection{O critério da ordem pública - crítica}

Quando o Legislador e o Judiciário - mesmo que intuitivamente - deparam-se com a necessidade de estabelecer limites à proteção do direito adquirido, acabam muitas vezes por se valer da noção - igualmente intuitiva - de prevalência da ordem pública, resolvendo por aí os mais intrincados conflitos de lei no tempo.

Contudo, a nosso ver o critério não deve ser adotado, quer aprioristicamente (pelo Legislador), seja na análise do caso concreto (pelo Juiz) ${ }^{248}$.

\footnotetext{
${ }^{236}$ FRANÇA, Rubens Limongi. Direito intertemporal brasileiro: doutrina da irretroatividade das leis e do direito adquirido, cit., p. 264.

${ }^{237}$ Id. Ibid., p. 265.

${ }^{238}$ Id. Ibid., p. 267.

${ }^{239}$ Id. Ibid., p. 288-289.

${ }^{240}$ Id. Ibid., p. 301.

${ }^{241}$ Id. Ibid., p. 321.

${ }^{242}$ Id. Ibid., p. 336.

${ }^{243}$ Id. Ibid., p. 363.

${ }^{244}$ Id. Ibid., p. 365.

${ }^{245}$ Id. Ibid., p. 395.

${ }^{246}$ Id. Ibid., p. 475 e ss.

${ }^{247}$ Id. Ibid., p. 197.

${ }^{248}$ Pouco importando, aqui, a conhecida mas a nosso ver dispensável - no que toca ao direito intertemporal divisão entre ordem pública de primeiro, segundo e terceiro níveis. A esse respeito, ensina Jacob Dolinger: "Vista a ordem pública na justaposição do direito interno com o direito internacional privado, teremos a gradação da ordem pública de forma a que o seu primeiro nível funcione para garantir o império de
} 
Embora não encontre tratamento uniforme nos tribunais superiores ${ }^{249}$, a questão da impossibilidade de o Legislador estabelecer normas de ordem pública ofensivas a direitos adquiridos já foi enfrentada pelo STF, que fechou questão ao julgar a ADIn 493-0/DF ${ }^{250}$, no âmbito da qual se discutia a constitucionalidade de artigos de lei que alteraram a forma de atualização monetária de contratos celebrados com as entidades integrantes do Sistema Financeiro da Habitação - SFH. Os dispositivos impugnados eram os artigos 18, caput e $\S \S 1^{\circ}$ e $4^{\circ}, 20,21$ e parágrafo único, 23 e $\S \S$, da Lei no $8.177 / 91$, que, em síntese - para nos atermos ao cerne da questão -, estabeleciam que as cláusulas de atualização monetária pela variação da UPC, da OTN e do salário mínimo deveriam ser substituídas pela taxa aplicável à remuneração básica dos depósitos de poupança - TR, mantidas as taxas de juros estabelecidas contratualmente.

De acordo com o que se lê nas informações prestadas pela Caixa Econômica Nacional, transcritas pela Procuradoria-Geral da Fazenda Nacional, a razão para tal alteração repousou na necessidade de fazer cessar a contínua depreciação dos valores de retorno dos financiamentos do SFH, ou seja, amortizações feitas pelos mutuários, as quais são necessárias à concessão de novas linhas de financiamento, pelo SFH. Já a Procuradoria da Fazenda Nacional ressaltou que "não sendo facultado às partes estipular cláusulas e condições pertinentes a questões como a moeda e o reajuste de obrigações, não há ato jurídico perfeito relativamente ao indexador e aos limites de reajuste, salvo no tocante às prestações vencidas e aos saldos devedores existentes na vigência da legislação pretérita”, conforme se lê no relatório elaborado pelo Ministro Moreira Alves.

Em reforço, a Advocacia Geral da União sustentou que não há direito adquirido contra a supressão de institutos jurídicos e que as operações definidas diretamente pela lei

\footnotetext{
determinados valores no plano do direito interno, impedindo que estes valores sejam desrespeitados pela vontade das partes. São, entre outras, as leis de proteção aos menores, aos incapazes, à família, à economia nacional e a determinados institutos civis e comerciais que constituem, de certa forma, a publicização do direito privado. (...) Segue-se, em segundo grau, a intervenção do princípio da ordem pública na aplicação das leis estrangeiras indicadas pelas regras de conexão do direito internacional privado. (...) Mais raro ainda o recurso à ordem pública quando se trata de reconhecer direitos adquiridos no exterior, que classificamos como o terceiro grau, ou o terceiro nível da ordem pública. (in DOLINGER, Jacob. A ordem pública internacional em seus diverso patamares. Revista dos Tribunais, São Paulo, v. 93, n. 828, p. 34-36, out. 2004). Em razão de tal premissa, refutamos também critério proposto por Vicente Ráo para a solução de conflito de leis no tempo, calcado este na "intensidade da força obrigatória das normas jurídicas segundo a natureza da matéria sobre a qual dispõem”. (in RÁO, Vicente. O direito e a vida dos direitos, cit., p. 407-408).

${ }^{249}$ Orientação destoante é encontrada, por exemplo, nos REsp no 394.671/PR, Rel. Min. Luiz Fux, j. 19.11.2002, v.u., e REsp n ${ }^{\circ}$ 94.850/SP, Rel. Min. Hamilton Carvalhido, j. 18.12.2002, v.u., entre outros.

${ }^{250}$ STF, Pleno, ADIN no 492-0/DF, Rel. Min. Moreira Alves, j. 25.6.1992, votação por maioria.
} 
- tais como a atualização monetária dos contratos do SFH - devem ser atingidas por lei nova, mormente porque tais normas são de direito público ${ }^{251}$.

Por outro lado, observou a Procuradoria Geral da República, em parecer tomado como relatório, que a TR não constitui índice neutro de atualização da moeda, e que sua adoção, pela lei $n^{\circ} 8.177 / 91$, objetivaria recompor as perdas do SFH e não apenas fazer cessar a depreciação dos valores de retorno. Representaria, pois, não apenas uma mudança do padrão monetário, mas uma verdadeira alteração dos contratos antes corrigidos pela UPC, OTN, pelo salário mínimo ou pelo salário mínimo de referência. Daí a violação, ao ver da Procuradoria Geral da República, ao artigo 5, inciso XXXVI, da Constituição Federal. São elucidativos os pequenos trechos citados abaixo: "Não se trata, portanto, de simples alteração de um índice de atualização
monetária por outro, mas sim da adoção de critérios de reajustamento e
de cálculo de juros que modificam o valor real das prestações, atingindo
substancialmente os contratos em curso de execução.

\section{(...)}

Sem embargo da tese sustentada por eminentes juristas, nos brilhantes pareceres proferidos a propósito da presente controvérsia, o princípio inscrito no art. $5^{\circ}$, XXXVI, da Constituição Federal, segundo o qual 'a lei não prejudicará o direito adquirido, o ato jurídico perfeito e a coisa julgada', compreende também as normas de direito público.

\section{$(\ldots)$}

Entretanto, a aplicação da lei nova aos facta pendentia, ou seja, aos efeitos das situações jurídicas constituídas no regime da lei antiga, configura-se, sem dúvida, retroatividade, embora atenuada em relação à hipótese de aplicação da lei aos efeitos consumados na vigência da lei anterior $^{252}$.

\footnotetext{
${ }^{251}$ Embora seja verdade que a lei que suprime instituições jurídicas tem efeito imediato e retroativo, inclusive sobre direitos adquiridos (item 3.5.3), esta não parece ser a hipótese em discussão. A premissa é verdadeira, mas inaplicável a este caso concreto.

${ }^{252} \mathrm{~A}$ ponderação merece reparo: embora parta de uma premissa verdadeira - de que os direitos adquiridos estão protegidos contra o advento da lei nova -, o parecer da Procuradoria Geral da República acaba por incidir em um equívoco corriqueiro - de que a lei que fere direitos adquiridos seria "retroativa". Conforme se vem afirmando, a lei que fere direitos adquiridos não é necessariamente aquela dotada de efeitos retroativos (item 2.3.1); na maior parte dos casos, a lei que fere direitos adquiridos terá operado com seus naturais efeitos imediatos. No caso, a Lei $\mathrm{n}^{\circ}$ 8.177/91 atingiu apenas efeitos presentes de fatos passados, operando tão-somente com efeito imediato sobre os fatos pendentes - efeito este ao qual demos a denominação de "imediato qualificado" (item 2.3.2). Teria operado com efeito retroativo apenas se tivesse determinado novo índice de correção também às parcelas vencidas antes do advento da nova lei. Assinalese, entretanto, que este equívoco não teve qualquer importância para o deslinde do feito e que o fato não ofusca o brilho do parecer.
} 
A doutrina cedo operou a clássica distinção entre retroatividade máxima, média e mínima ${ }^{253}$.

\title{
(...)
}

Seja como for, nos termos em que é formulada na Constituição Federal e na Lei de Introdução ao Código Civil, a proteção ao ato jurídico perfeito e ao direito adquirido refere-se com igual força aos facta praeterita e aos facta pendentia".

Em voto que viria a ser vencedor, o relator do caso, Ministro Moreira Alves, decidiu que, não importando sua natureza, a lei nova deve respeitar o ato jurídico perfeito, o direito adquirido e a coisas julgada. Utilizando ofensa a direitos adquiridos como sinônimo de retroatividade - equívoco este que, espera-se, já tenha sido desfeito nas páginas anteriores (itens 2.3.1 e 2.3.2) 254 $^{2}$, o Ministro Moreira Alves proferiu julgado paradigmático no âmbito do qual sustenta que "esse preceito constitucional se aplica a toda e qualquer lei infraconstitucional, sem qualquer distinção entre lei de direito público e lei de direito privado, ou entre lei de ordem pública e lei dispositiva”. Apoiou-se o Ministro Moreira Alves em voto anterior, proferido quando do julgamento da Representação de Inconstitucionalidade $\mathrm{n}^{\circ}$ 1.451, no qual analisara o alcance da restrição contida no artigo $5^{\circ}$, inciso XXXVI, da Constituição Federal, concluindo, na ocasião, que:

\begin{abstract}
"Aliás, no Brasil, sendo o princípio do respeito ao direito adquirido, ao ato jurídico perfeito e à coisa julgada de natureza constitucional, sem qualquer exceção a qualquer espécie de legislação ordinária, não tem sentido a afirmação de muitos - apegados ao direito de países em que o
\end{abstract}

\footnotetext{
${ }^{253}$ Para os autores que adotam tal distinção, ocorre retroatividade mínima quando o efeito imediato atinge os efeitos futuros dos fatos anteriores à norma, retroatividade média quando a lei nova atinge os efeitos pendentes de fatos passados e retroatividade máxima quando atinge fatos consumados sob o império da norma revogada, conforme já exposto ao tratarmos do direito intertemporal espanhol (item 1.4.1). A nosso ver, a distinção nasce do equívoco de se equiparar o efeito imediato ao retroativo. Mais: a distinção é prova de que, por vezes, o efeito imediato é tratado propositalmente como sinônimo de efeito retroativo. Em sistemas como o nosso, que não vedam a retroatividade mas sim a ofensa a direitos adquiridos, não faz o menor sentido equiparar efeito imediato e retroativo - teria, repise-se, em sistemas estrangeiros que vedam a retroatividade sem vedar a ofensa a direitos adquiridos, pois, em se equiparando o efeito imediato qualificado ao efeito retroativo, estar-se-ia impedindo a ocorrência daquele, e protegendo-se assim os efeitos presentes dos fatos passados. Como o nosso sistema não veda a retroatividade - desde que expressa -, não tem qualquer utilidade a equiparação; não será ela que irá obstar o efeito imediato qualificado. Daí que, repita-se, a indagação a ser feita não é se a lei nova é retroativa (seja qual for esta retroatividade, mínima, média ou máxima), mas sim se o efeito imediato da lei nova - e, em casos excepcionais, o efeito retroativo, na correta acepção do termo, daquele que se volta a fatos passados - fere ou não o direito adquirido, o ato jurídico perfeito ou a coisa julgada. Concluindo o intérprete que a lei nova os atinge, deverá garantir a aplicação da lei antiga, obstando o efeito imediato qualificado e o retroativo. Em outros termos, deverá garantir a ultratividade da norma anterior, não significando isto que a norma nova fosse retroativa, ou que tenha o intérprete obstado os efeitos da lei nova com fundamento em proibição à retroatividade.

${ }^{254}$ Valem, aqui, as mesmas observações feitas nas duas notas anteriores.
} 
preceito é de origem meramente legal - de que as leis de ordem pública se aplicam de imediato alcançando os efeitos futuros do ato jurídico perfeito ou da coisa julgada, e isso porque, se se alteram os efeitos, é óbvio que se está introduzindo modificação na causa, o que é vedado constitucionalmente".

Após fazer longa digressão sobre o direito intertemporal e analisar a natureza da TR - reconhecendo que esta não constitui índice de atualização do valor monetário -, o Ministro Moreira Alves decidiu que a Lei $\mathrm{n}^{\circ} 8.177 / 91$ seria inconstitucional, por ofensa ao artigo $5^{\circ}$, inciso XXXVI, da Constituição Federal, por introduzir nos contratos do SFH elemento não acordado entre as partes, ferindo o ato jurídico perfeito e o direito adquirido. Embora a questão da ordem pública não fosse absolutamente necessária para o deslinde do feito, o tema foi analisado em profundidade, chegando-se à conclusão de que, por constar do texto constitucional, o Legislador ordinário não pode estabelecer lei ofensiva a direitos adquiridos, mesmo que de ordem pública. Tal discussão, na orientação do STF, teria lugar apenas em países onde o princípio da irretroatividade é albergado em nível infraconstitucional.

Debatido em Plenário, o voto do Ministro Moreira Alves saiu-se vitorioso por maioria $^{255}$. Embora lateralmente, ficou assentado - ao que parece de maneira definitiva -, que não pode o Legislador prescrever normas de ordem pública ofensivas a direitos adquiridos. Ficou assim redigida a ementa do julgado:

"Ementa: Ação direta de inconstitucionalidade.

- Se a lei alcançar os efeitos futuros de contratos celebrados anteriormente a ela, será essa lei retroativa (retroatividade mínima) porque vai interferir na causa, que é um ato ou fato ocorrido no passado.

- O disposto no artigo $5^{\circ}$, XXXVI, da Constituição Federal se aplica a toda e qualquer lei infraconstitucional, sem qualquer distinção entre lei de direito público e lei de direito privado, ou entre lei de ordem pública e lei dispositiva. Precedente do S.T.F..

- Ocorrência, no caso, de violação de direito adquirido. A taxa de referência (TR) não é índice de correção monetária, pois, refletindo as variações do custo primário da captação dos depósitos a prazo fixo, não constitui índice que reflita a variação do poder aquisitivo da moeda. Por isso, não há necessidade de se examinar a questão de saber se as normas

\footnotetext{
${ }^{255}$ Valendo mencionar o dissenso do Ministro Ilmar Galvão, para quem a TR seria índice de correção monetária, o qual poderia ser substituído pela lei nova porque "não há direito adquirido a determinado padrão monetário, incidindo sobre o contrato, nesse ponto, de maneira inexorável, o novo índice que, de acordo com a lei, passou a espelhar o fenômeno da inflação”. Idêntico entendimento abraçou o Ministro Marco Aurélio Mello, ao menos no que toca à questão da natureza da TR e da ausência de violação do direito adquirido.
} 
que alteram índice de correção monetária se aplicam imediatamente, alcançando, pois, as prestações futuras de contratos celebrados no passado, sem violarem o disposto no artigo $5^{\circ}$, XXXVI, da Carta Magna.

- Também ofendem o ato jurídico perfeito os dispositivos impugnados que alteram o critério de reajuste das prestações nos contratos já celebrados pelo sistema do Plano de Equivalência Salarial por Categoria Profissional (PES/CP).

Ação direta de inconstitucionalidade julgada procedente, para declarar a inconstitucionalidade dos artigos 18 , 'caput' e parágrafos $1^{\circ}$ e $4^{\circ} ; 20 ; 21$ e parágrafo único; 23 e parágrafos; e 24 e parágrafos, todos da Lei n. 8.177, de $1^{\circ}$ de março de 1991 ”.

\section{Referendamos a conclusão.}

Por sua vez, também não deve o Juiz, na análise do caso concreto, valer-se da dicotomia direito adquirido versus ordem pública para buscar um limite à proteção do direito adquirido - deverá se valer de critério outro, do que se tratará mais adiante. As razões são duas: (1) o conceito de ordem pública é de difícil concreção; e (2) o direito adquirido não poderá ser contraposto a nenhuma idéia que se tenha de ordem pública.

A dificuldade em se definir ordem pública tem sido anotada pelos mais abalizados juristas. Reynaldo Porchat, por exemplo, o dizia com contundência: "esse criterio é, porém, inteiramente falso, tendo sido causa das maiores confusões na solução das questões de retroactividade. Antes de tudo, cumpre ponderar que é difficilimo discriminar nitidamente aquillo que é de ordem publica e aquillo que é de ordem privada" 256.

Por outro lado, aqueles que tentam conceituar ordem pública acabam fazendo-o de forma muito genérica e abrangente ${ }^{257}$. Por exemplo, Maria Helena Diniz define ordem pública como "patrimônio espiritual do povo, por refletir seus hábitos, suas tradições, sua liberdade, suas idéias políticas, econômicas, religiosas, morais, seus direitos fundamentais em

\footnotetext{
${ }^{256}$ in PORCHAT, Reynaldo. op. cit., p. 66.

${ }^{257}$ Interessante a ponderação de Carlos Young Tolomei: "por mais que possa ser cotidianamente invocado, e por mais que seja natural se admitir, como pressuposto teórico, que a ordem pública se sobrepõe ao interesse individual, a verdade é que esta afirmação se apresenta normalmente dissociada de uma escorreita argumentação jurídica, resumindo-se, na maior parte das vezes, em simples reflexo ou repetição de um sentimento generalizado. Em não raros casos, parece ser elevado a verdadeiro dogma jurídico, absoluto e por si inexplicável. (...) aqui, diferentemente do que ocorre quando tratamos do direito adquirido, não estamos falando rigorosamente de uma categoria jurídica (alguma suposta categoria da 'ordem pública'), mas de um princípio que, bem longe de ser pragmático, é de natureza filosófica e moral, natureza esta essencialmente relativa e alterável com o tempo; daí sua indefinição objetiva". (in TOLOMEI, Carlos Young. A proteção do direito adquirido sob o prisma civil-constitucional: uma perspectiva sistemáticoaxiológica. Rio de Janeiro: Renovar, 2005. p. 222-223).
} 
determinada época e lugar"258 . Já Maria Coeli Simões Pires acaba por equipará-la a interesse público, o que não nos parece acertado ${ }^{259}$.

Uma análise histórica demonstra que a ordem pública não pode ser contraposta, pelo Juiz, à proteção do direito adquirido: a expressão ordem pública nasce ao fim da revolução francesa, para exprimir em princípio jurídico a afirmação dos novos valores do povo francês. Conforme informa Giovanni B. Ferri,

\begin{abstract}
"era necessário, depois da desordem, o restabelecimento da ordem; era necessário pacificar os ânimos e devolver segurança ao dia a dia, ao trânsito, ao comércio (...) isto é, procurar finalmente traduzir em norma e princípios jurídicos aqueles ideais que se fundavam sobre a liberdade e dignidade do indivíduo, sobre a exaltação dos seus fundamentais direitos, da sua personalidade de homem e do citoyen que a revolução, se não traíra, havia certamente enganado" 260 .
\end{abstract}

A fórmula vai ser inscrita no Código de Napoleão, então, com o objetivo de consolidar os ideais nascidos na revolução. Giovanni B. Ferri demonstra que "a fórmula 'ordem pública' tem uma data de nascimento suficientemente precisa; essa aparece pela primeira vez no Código de Napoleão (...)"261.

Não se pode perder de vista, portanto, que a expressão ordem pública - ao que se verifica de sua origem - quer significar um conjunto de valores da sociedade, privados e públicos, cuja manutenção se deseja em prol da segurança das relações jurídicas. A ordem pública irá limitar, pois, tudo que venha a afrontar esta almejada segurança, que na França pós-revolução se exprimia principalmente na tutela da propriedade e da liberdade.

${ }^{258}$ in DINIZ, Maria Helena. Lei de Introdução ao Código Civil interpretada. 3. ed. São Paulo: Saraiva, 1997. p. 359.

${ }^{259}$ A autora afirma: "cogita-se, neste trabalho, da ordem pública tomada em sentido amplo e não como ordem material da vida coletiva, relacionada com a idéia de segurança; mais especificamente, acolhe-se ordem pública como noção de esfera pública em sentido lato, em teor de normatividade ou de interesse. A opção, no entanto, não se faz sem risco, bastando registrar as perplexidades que a locução ordem pública suscita, seja na doutrina, seja na jurisprudência, ou ainda no campo do direito positivo (...)" (in PIRES, Mara Coeli Simões. Direito adquirido e ordem pública: segurança jurídica e transformação democrática. Belo Horizonte: Del Rey. 2005. p. 354).

${ }^{260}$ in FERRI, Giovanni B. Ordine pubblico (dir. Priv.) In: ENCICLOPÉDIA del Diritto. Milano: Giuffrè, 1980. v. 30, p. 1052. Tradução livre de "Ocorreva, dopo il disordine, ristabilire l'ordine; ocorreva pacificare glis animi i ridare sicurezza alla vita di ogni giorno, al traffici, al commercio (...) cioé, cercare finalmente di tradurre, in norme e princìpi giuridici, quelle ideali che si fondavano sulla libertà e sulla dignità dell'individuo, sulla esasltazione di suoui fondamentali diritti, della sua personalità di uomo e di cytoyes che la Rivoluzione, se non tradito, aveva certamente deluso".

${ }^{261}$ in Id. Ibid., p. 1051. Tradução livre de "Ė necessario ricordare, in proposito, come la formula 'ordine pubblico' abbia una data di nascita sufficientemente precisa; essa appare per la prima volta nel codice di Napoleone (...)" 
Nas palavras singelas de Goffredo Telles Junior, existirá ordem quando houver "uma disposição conveniente de coisas, sendo que a disposição só pode ser considerada conveniente quando alcança o fim em razão do qual ela é dada às coisas” ${ }^{262}$. Ou seja, haverá ordem pública se resguardados os objetivos visados pelo sistema, onde resguardados corresponde à disposição dada às coisas e objetivos visados pelo sistema à razão pela qual as coisas foram dispostas.

Em comentário à ordem pública no sistema italiano, Giovanni B. Ferri ensina que

"É claro, então, como nesta perspectiva a função dos limites que a ordem pública é chamada a desenvolver nos confrontos da autonomia negocial não exprime (...) a exigência de uma supremacia do interesse público sobre o interesse dos particulares e a possibilidade de que este possa e deva ceder àquele, quando as situações concretas o exijam; a ordem pública, como limite ao agir negocial exprime mais especificamente a exigência de que os particulares, com as suas convenções, não se sobreponham àqueles valores fundamentais sobre os quais se funda a ordem social: mas que construam suas relações no respeito àqueles valores e àqueles princípios que o Estado considera essenciais e caracterizadores da organização social de um determinado momento histórico.

\section{(...)}

Esta função 'conservadora' (nas relações entre particulares) dos valores e princípios fundamentais sobre os quais se funda todo o sistema do ordenamento jurídico (...) se desenvolve de novo no sistema do código atual.

Certo que os valores e princípios 'portadores' do nosso ordenamento jurídico são em parte diversos daqueles que caracterizavam o sistema pelo qual a ordem pública foi, pela primeira vez, elaborada e introduzida em um código civil.

Como no sistema fascista estas escolhas e estes valores encontraram as suas formulações e expressões no ordenamento corporativo e na Carta de trabalho que os inspirava (...), no nosso sistema atual é à Constituição republicana que devemos nos remeter para encontrar os valores e princípios hoje fundamentais no nosso ordenamento jurídico"263.

\footnotetext{
${ }^{262}$ in TELLES JUNIOR, Goffredo da Silva. op. cit., p. 3.

${ }^{263}$ in FERRI, Giovanni B. op. cit., p. 1053. Tradução livre de "É chiaro, allora, come in questa prospettiva la funzione di limite che l'ordine pubblico è chiamato a svolgere nei confronti della autonomia negoziale non esprime (...) l'esigenza di una supremazia dell'interesse pubblico sull'interesse dei privati e la possibilità che questo possa e debba cedere a quello, quando le situazioni concrette lo esigano; l'ordine pubblico, come limite all'agire negoziale, esprime più l'esigenza che $i$ privati, con le loro convenzioni, non sovvertano quei valori fondamentali su cui si fonda l'ordine sociale: ma che realizzino i loro rapporti nel rispetto di quei valori e quei princìpi che lo Stato considera essenziali e caratterizzanti l'organizzazione sociale di un determinato momento storico.

(...)

Questa funzione 'conservatrice' (nei rapporti tra privato e privato) dei valori e princìpi fondamentali su cui si fonda l'intero sistema dell'ordenamento giuridico (...) ancora svolge nel sistema di codice attuale.
} 
Ordem pública significa, portanto, os valores em que se inspira um determinado sistema, os quais estão expressos, no caso brasileiro, na Constituição Federal de 1988. O respeito à ordem pública implica, pois - no atual momento histórico brasileiro -, o resguardo dos valores fundantes de nossa Carta Política, como o da dignidade da pessoa humana e da segurança jurídica. Ou seja, os mesmos interesses que o direito adquirido visa a resguardar.

Logo, ordem pública e direito adquirido são conceitos que não podem ser contrapostos, pelo Juiz - na análise do caso concreto -, pois ambos erigem-se sobre os mesmos valores e visam a uma mesma finalidade. Como já frisava Reynaldo Porchat, "a simples invocação de um motivo de ordem publica não basta para justificar a offensa ao direito adquirido, cuja inviolabilidade, no dizer de GABBA é tambem um forte motivo de interesse publico",264.

\subsubsection{Os critérios nascidos no julgamento do $R E n^{0}$ 141.190-2/SP: teoria da imprevisão e ponderação de princípios - crítica}

Interessantes são dois critérios nascidos no acalorado julgamento do RE $\mathrm{n}^{\circ}$ 141.1902/SP ${ }^{265}$. Discutia-se no caso se, com a instituição do Plano Bresser (que impôs o congelamento de salários e preços por 90 dias), poderiam ser aplicados fatores de deflação - TABLITA aos certificados de depósitos bancários - CDB com valor de resgate pré-fixado anteriormente à contratação da aplicação financeira.

Em tempos de inflação galopante, as instituições financeiras ajustavam previamente o valor que seria pago, a título de correção monetária, quando do resgate do investimento. Por meio de uma projeção da inflação do período, a instituição financeira acordava o quanto pagaria ao investidor a título de atualização da moeda, assumindo o risco de uma eventual inflação a menor.

Certo $i$ valori e i princìi 'portanti' del nostro ordinamento giuridico sono in parte diversi da quelli che caratterizzavano il sistema per il quale l'ordine pubblico fu, per la prima volta, elaborato e introdotto nel codice civile.

Come nel sistema fascista queste scelte e queste valori trovarono la loro formulazione ed espressione nell'ordinamento corporativo e nella Carta del lavoro che lo esprimeva (...) nel nostro sistema attuale à alla Costituzione reppublicana che dobbiamo far capo per trovare $i$ valori e i princìpi oggi fondamentali nel nostro ordinamento giuridico".

${ }^{264}$ in PORCHAT, Reynaldo. op. cit., p. 66.

${ }^{265}$ STF, Pleno, RE n ${ }^{\text {o }}$ 141.190-2/SP, Rel. Min. Ilmar Galvão, j. 14.9.2005, votação por maioria. 
Com a instituição do Plano Bresser, pelo Decreto-Lei nº 2.335/87, a inflação caiu a zero, artificialmente, gerando, a princípio, um ganho para o investidor - que ajustara previamente um índice superior ao que viria a ser a inflação nos 90 dias do plano. Para evitar perdas às instituições financeiras, o Plano Bresser previu a aplicação de fatores de deflação denominados TABLITA aos referidos investimentos, determinando - também artificialmente - a redução dos índices antes acordados com os investidores.

Como não poderia deixar de ser, a medida suscitou o inconformismo destes, os quais se voltaram judicialmente, ancorados no artigo $5^{\circ}$, inciso XXXVI da Constituição Federal, contra a ofensa ao direito de perceber os valores acordados a título de atualização monetária. A controvérsia fica clara e bem resumida em trechos de voto do Ministro Celso de Mello, nos quais se lê:

\begin{abstract}
"A instituição financeira ora recorrida, invocando legislação superveniente à pactuação do negócio jurídico celebrado com os recorrentes (Decreto-lei $\mathrm{n}^{\mathbf{o}} 2.342$, de 10.7.87), ausente qualquer reforma do padrão monetário, veio a creditar em conta destes, na data do respectivo vencimento, valores a menor, resultantes dos fatores de deflação aplicados sobre o montante a ser resgatado nos precisos termos do ajuste contratual.
\end{abstract}

\title{
(...)
}

Os ora recorrentes, invocando o princípio constitucional da irretroatividade das leis e o postulado da incolumidade das situações jurídicas definitivamente consolidadas, assim fundamentaram, em seus aspectos essenciais, o apelo extremo por eles interposto (...)".

O relator do caso, Ministro Ilmar Galvão, entendeu que a TABLITA não ofende o direito adquirido, porque, assim como se dá com as alterações de padrão monetário, os fatores de deflação apenas adequariam a obrigação a uma nova condição da moeda, não alterando a obrigação em si. O voto em questão pode ser sintetizado nos trechos abaixo:

"Não ocorre, aí, o fenômeno da alteração do contrato, constitucionalmente vedado entre nós, mas tão-somente da expressão monetária das obrigações dele decorrentes. Uma coisa são as obrigações contratuais; coisa diversa é a sua expressão monetária.

Se assim é relativamente às sucessivas leis que instituem novos índices de correção monetária, efeito diverso não se poderia colher daqueles que, conquanto menos freqüentes, instituem índices deflatores, denominados 'tablita', em face de choques heterodoxos, destinados a deter a espiral inflacionária, caso destes autos". 
Acompanhou-o o Ministro Sepúlveda Pertence, para quem a TABLITA apenas restabelece o equilíbrio do contrato, resguardando a sua substância:

"Assim, tal como a aplicação aos contratos em curso do novo estatuto legal da correção monetária, há de aplicar-se o deflator, em ambas as hipóteses, altera-se o estatuto legal do poder de liberação da moeda nominal para restabelecer o equilíbrio inicial do contrato.

A incidência da lei nova aí, ao invés de prejudicar, restabelece a substância do contrato.

Não se trata de conferir à lei nova o status de lei de ordem pública à qual não seria possível opor o princípio do ato jurídico perfeito; esse raciocínio foi afastado pelo Tribunal no julgamento da ADIN 493, Moreira Alves (RTJ 143/724)."

Em oposição, os Ministros Celso de Mello e Marco Aurélio sustentaram que o direito adquirido teria sido ofendido porque a atualização pré-fixada teria natureza de contrato aleatório, no âmbito do qual a instituição financeira assume o risco de uma inflação a menor, sendo daí incabível a comparação com as meras alterações do padrão monetário.

São palavras do Ministro Celso de Mello:

"A obrigação contratual assumida pelo Banco de Crédito Nacional S.A., que ajustou com os autores da aplicação financeira cláusula de atualização monetária pré-fixada, foi bem definida, seu alcance e conteúdo, pelos ora recorrentes, que fizeram consignar que a característica essencial da aplicação financeira em questão, 'ou seja, com rendimento pré-fixado, reside no fato de que as partes limitam suas vantagens e eliminam os riscos de eventuais oscilações do mercado. (...)'

\section{(...)}

Sendo assim, o negócio jurídico pactuado pelos sujeitos deste procedimento recursal traduzia, na concreção do seu alcance, uma manifestação lícita das vontades e que tinha por fim - dentre seus precípuos objetivos - criar uma relação de direito material entre os aplicadores de recursos e a instituição financeira, impondo-se, prospectivamente, de modo categórico e imperativo, à observância do próprio Estado.

A aplicação superveniente de atos estatais de natureza legislativa, de que decorra, como efeito conseqüiencial, a desconsideração de cláusulas contratuais precedentemente estipuladas pelos sujeitos da operação negocial, não se justifica em face da norma de sobredireito consagrada pelo constitucionalismo brasileiro - com a só exceção da Carta Federal de 1937 - desde a vigência da Constituição Política do Império do Brasil que 
proibia o legislador de prescrever normas com efeito retroativo (art. 179, III)

\section{$(\ldots)$}

Não desconheço, Senhor Presidente, que a Colenda Primeira Turma do Supremo Tribunal Federal registra precedente 'no sentido de que as normas que alteram o padrão monetário e estabelecem os critérios para a conversão dos valores em face dessa alteração se aplicam de imediato, alcançando os contratos em curso de execução, uma vez que elas tratam de regime legal de moeda, não se lhes aplicando, por incabíveis, as limitações do direito adquirido e do ato jurídico perfeito...' (RTJ 134/413, Rel. Min. MOREIRA ALVES).

Impõe-se observar, no entanto, que essa decisão foi proferida em um contexto completamente diverso daquele em cujo âmbito se delineou a controvérsia ora suscitada, eis que - ao contrário do que se registrou no precedente invocado - não se verificou, no caso em exame, qualquer modificação no padrão monetário vigente no País, que constitui, quando ocorrente, uma típica hipótese configuradora do factum principis."

São palavras do Ministro Marco Aurélio: “a álea é inerente a essa espécie de investimento - CDB".

Instaurado o impasse - que a bem da verdade poderia ter sido resolvido pela definição da natureza jurídica do CDB pré-fixado -, foram suscitados dois novos critérios para limitação do direito adquirido dos investidores. Como o critério da ordem pública fora refutado no julgamento da ação direta de inconstitucionalidade $n^{\circ}$ 493-0/DF, analisada no item anterior, os Ministros Maurício Corrêa e Gilmar Mendes puseram-se a criar uma alternativa que contornasse a proteção do artigo $5^{\circ}$, inciso XXXVI, da Constituição Federal.

O Ministro Maurício Corrêa sustentou que, embora existisse ato jurídico perfeito, o Plano Bresser não o ofenderia, pois estaria equilibrando uma situação que ele mesmo havia desequilibrado, mantendo assim a essência do ato jurídico perfeito. O Ministro Maurício Corrêa viu nisto uma aplicação antecipada - em sede legislativa - da teoria da imprevisão, o que haveria de ser referendado pelo Poder Judiciário "como meio para corrigir distorção injusta e de expressiva proporção surgida na vigência dos contratos”. In verbis:

"Concluo esta introdução a esta parte do meu voto dizendo que entendo que só se pode enfrentar corretamente a questão recorrida penetrando no campo da teoria da imprevisão.

Todos aprendemos que são princípios observados na formação dos contratos a liberdade de contratar, o consentimento, a boa-fé e o surgimento 
de lei entre as partes (pacta sunt servanda); este último, na evolução do direito, teve abalado o seu caráter absoluto com o advento da fórmula contractus qui habent tractum sucessivumet dependentiam de futuro, rebus sic stantibus intelliguntur, mais conhecida pela expressão resumida de 'cláusula rebus sic stantibus'.

\section{(...)}

Acolhida a teoria da imprevisão como meio para corrigir distorção injusta e de expressiva proporção surgida na vigência dos contratos, verifica-se que estas consequiências supervenientes podem ser ocasionadas por fatos da natureza ou por fatos do príncipe, sendo que estes podem decorrer de intervenção direta do Estado nos contratos ou de medidas gerais com reflexo nos contratos.

No caso presente o factum principis ocorreu com o súbito e inesperado congelamento dos preços, determinado tanto pelo 'Plano Cruzado' (art. 36 do Decreto-lei no 2.283, de 27.02.86, e art. 35 do Decreto-lei ${ }^{\circ} 2.335$, de 12.06.87). Este factum principis provocou momentânea paralisação da inflação e conseqüiente supressão da correção monetária, atingindo, por via reflexa, os contratos em vigor que continham, expressa ou implicitamente, cláusula de correção monetária pré-fixada; disto resultaria que os devedores de tais contratos continuariam a dever uma correção monetária que não mais existia, onerando excessivamente uma das partes contratantes.

Daí porque simultaneamente com a ocorrência do factum principis, 'o próprio' aplicou, antecipadamente, a teoria da imprevisão: daí a tabela de deflatores, conhecida por 'tablita'.

\section{(...)}

Assim, Senhor Presidente, malgrado tenha se concretizado, no caso, o ato jurídico perfeito, tenho que esta garantia constitucional deve ser compatibilizada com a teoria da imprevisão, para restabelecer o equilíbrio das partes no contrato.

\section{(...)}

Fico, assim, numa posição intermediária, que me parece suficientemente estruturada juridicamente e cujos efeitos práticos da decisão trazem uma solução mais justa, ou seja, o contrato vigora até ofactum principis, e a partir daí, pela aplicação da teoria da imprevisão expressamente prevista pelo legislador, deflaciona-se apenas os rendimentos supervenientes com a utilização das 'tablitas', preservando-se, desta forma, a integridade do 'capital investido'.

Este voto médio, Senhor Presidente, corta os exageros que levariam inexoravelmente ao enriquecimento de uma parte em detrimento da outra, pois, o investidor terá os rendimentos pactuados até a data do 'choque' econômico, e a partir daí os rendimentos ajustados à nova realidade econômica do País, sem que seja alcançado o seu capital até esta data; do lado do devedor, igualmente, haverá o pagamento dos encargos devidos de acordo com o pacto até a data da alteração das regras econômicas, e a partir daí, serão eles também ajustados de acordo com a nova realidade, sem que ocorra, agressão à integridade do capital que lhe foi confiado". 
Por sua vez, o Ministro Gilmar Mendes ponderou que o caso poderia ser resolvido pela aplicação do princípio da proporcionalidade, consubstanciado no binômio necessidade e adequação da providência legislativa. Para o Ministro Gilmar Mendes, tal ponderação, aliada a uma análise econômica dos fatos, levaria à conclusão de que "a norma analisada apresenta-se constitucional, pois os elementos concretos demonstram (...) que o fator de deflação (...) acabou por proteger o núcleo essencial do direito fundamental". A fundamentação do Ministro Gilmar Mendes pode ser sintetizada nos trechos abaixo:

"A opção pelo congelamento de preços e salários pelo prazo de 90 dias,
como política econômica, não poderia ser implementada sem alteração
substancial das regras de mercado, que também atingiram, como
consequêencia inevitável, os contratos de aplicações financeiras de resgate
com valor pré-fixado.

Neste particular, pertinente a doutrina do professor Konrad Hesse, a qual reconhece no princípio da proporcionalidade tanto uma proteção contra as limitações arbitrárias ou desarrazoadas (teoria relativa), como também contra a lesão ao núcleo essencial dos direitos fundamentais (HESSE, Srundzüge des Verfassungsrechts, p. 149). É que, observa Hesse, a proporcionalidade não há de ser interpretada em sentido meramente econômico, de adequação da medida limitadora ao fim perseguido, devendo também cuidar da harmonização dessa finalidade com o direito afetado pela medida.

O vício de inconstitucionalidade substancial decorrente do excesso de poder legislativo implica a aferição da compatibilidade da lei com os fins constitucionalmente previstos, ou seja, à investigação sobre a adequação (Geeignetheit) e a necessidade (Erforderlichkeit) do ato legislativo supostamente excessivo (CANOTILHO, Direito Constitucional, cit., p. 617-618; SCHNEIDER, Zur Verhältnismässiketskontrolle, in SATARK, Budesverfassugsgericht, cit., v. 2, p. 392. ERICHSEN, Hans-Uwe \& MARTENS, Wolfgang (org).

\section{(...)}

A utilização do princípio da proporcionalidade ou da proibição de excesso no Direito constitucional envolve, em um primeiro plano, a apreciação da necessidade (Erforderlichkeit) e adequação (Geeignetheit) da providência legislativa.

De qualquer forma, um juízo definitivo sobre a proporcionalidade da medida há de resultar da rigorosa ponderação e do possível equilíbrio entre o significado da intervenção para o atingido e os objetivos perseguidos pelo legislador (proporcionalidade em sentido estrito) (PIEROTH/SCHILINK, Grudrechte - Staatsrech II, p. 67). A proporcionalidade em sentido estrito assumiria, assim, o papel de um 'controle de sintonia fina' (Stimmigkeitskontrolle), indicando a justeza da solução encontrada ou a necessidade de sua revisão (PIEROTH/SCHILINK, Grudrechte - Staatsrech II, p. 68). 


\section{(...)}

Na situação posta para análise, pelos dois primeiros critérios - adequação e necessidade - a norma que alterou a política monetária e impôs a tablita para os contratos de aplicações financeiras com valor de resgate pré-fixado passa pelo crivo da proporcionalidade, restando a análise do terceiro e mais concreto dos critérios: a proporcionalidade em sentido estrito.

Exame rigoroso do equilíbrio entre a restrição imposta pela norma em questão e os objetivos perseguidos pelo legislador ao editá-la, a proporcionalidade em sentido estrito somente pode ser evidenciada a partir da investigação em concreto de seus pressupostos e consequiências.

As premissas postas no voto-vista do Min. Nelson Jobim são imprescindíveis para esse juízo.

A primeira premissa é a de que a compreensão do caso, no âmbito jurídico, passa pela compreensão do fenômeno econômico, devendo-se ter em mente que as mudanças na política econômica, pela intervenção legislativa do Estado, têm repercussão no fenômeno econômico que dá origem ao acordo entre as partes. Acertada a conclusão do Min. Nelson Jobim: 'Alterada essa base - seja por mudança na moeda, seja por radical intervenção na economia, como é o congelamento -, o acordo entre as partes deve sofrer modificações no ajuste nominal a fim de ser mantido o ajuste substancial.'

Destarte, não há como deixar de registrar aqui que o fator de deflação, ora questionado, ao invés de ferir o pactuado anteriormente, assegurou a manutenção possível do que havia sido pactuado, tendo em vista que o cenário era de redução drástica da inflação.

\section{(...)}

Assim, mesmo diante do critério da proporcionalidade em sentido estrito, a norma analisada apresenta-se constitucional, pois os elementos concretos demonstram (principalmente os percentuais de rendimento real $\mathrm{e}$ rendimento pré-fixado) que o fator de deflação, ao contrário do que se alega no presente recurso, ao invés de violar, acabou por proteger o núcleo essencial do direito fundamental envolvido (que em última análise é o direito de propriedade), resguardando-se reflexamente também o direito adquirido e ato jurídico perfeito, como corolários da segurança jurídica e do próprio Estado de Direito. Nas palavras do Min. Nelson Jobim: 'de uma contratação com rendimento real, na melhor das hipóteses, negativo em $-2,694 \%$, passaria para um rendimento positivo de $7,32 \%$ ).

\section{(...)}

No caso específico dos autos, não parece que a tablita tenha extrapolado os limites da proporcionalidade, pois muito embora tenha havido a aplicação do fator de deflação aos rendimentos da aplicação financeira contratada com valor de resgate pré-fixado, as consequiências foram mais benéficas ao investidor do que se a questão não houvesse sido regulamentada pelo legislador". 
Nenhum dos dois critérios deve ser adotado aprioristicamente.

A aplicação da imprevisão como critério limitador da proteção do direito adquirido parece possível apenas se invocada por um dos contratantes e se presentes, concomitantemente, os seguintes requisitos $^{266}$ : (1) a existência de um negócio comutativo; (2) a norma como um fator imprevisível e que altere radicalmente as condições em que tiver sido entabulado o negócio; (3) a ocorrência de onerosidade excessiva para uma das partes, causada diretamente pelo advento da nova norma; e (4) a existência de vantagem à outra parte. Não será propriamente um critério limitador do direito adquirido, mas sim - pela natureza e finalidade da teoria da imprevisão - um equilibrador dos contratos, aplicável somente aos direitos adquiridos em razão de relações negociais.

No caso sob análise, a utilização da imprevisão para limitar a proteção do direito adquirido pressuporia, pois, que (1) a instituição financeira tivesse formulado alegação nesse sentido, o que não ocorreu; (2) tivessem os Ministros enfrentado a questão da natureza jurídica do CDB pré-fixado, o que não foi feito - à exceção dos Ministros Celso de Mello e Marco Aurélio; (3) fosse a deflação considerada um fator imprevisível, o que não parece razoável se levarmos em conta que a recorrida era uma instituição financeira. Aliás, chama atenção o fato de que, ao julgar em favor do poder econômico, o STF tenha considerado a deflação um fator imprevisível, ao passo que, ao julgar contra o poder econômico, o STF consolidou o entendimento de que a inflação - outro lado da mesma moeda - não constitui fator imprevisível; e (4) tenha ocorrido vantagem para a outra parte, o que parece ter existido, porém dentro da aleatoriedade do negócio.

Por outro lado, não parece que se possa utilizar a proporcionalidade como um critério geral para limitação da proteção do direito adquirido ${ }^{267}$. A ponderação de princípios é válida e

\footnotetext{
${ }^{266}$ A esse respeito, oportuna é a lição do Ministro Carlos Alberto Menezes Direito: "Como norma absolutamente excepcional, operaria em benefício do devedor quando concorressem três elementos: a) alteração radical no ambiente objetivo existente ao tempo do contrato, decorrente de circunstâncias imprevistas e imprevisíveis; b) onerosidade excessiva para o devedor e não compensada por outras vantagens auferidas anteriormente, ou ainda esperáveis diante dos termos do ajuste; c) enriquecimento inesperado e injusto para o credor, como conseqüência direta da superveniência imprevista”. (in DIREITO, Carlos Alberto Menezes. A livre negociação dos índices: leis de ordem pública e teoria da imprevisão. Revista dos Tribunais, São Paulo, v. 80, n. 672, p. 75-76, out. 1991).

${ }^{267}$ Interessante embate travou Thiago Massao Cortizo Teraoka, em sua dissertação de mestrado (TERAOKA, Thiago Massao Cortizo. op. cit., p. 85-87), contra orientação proposta por Cláudia Toledo, em trabalho monográfico dedicado ao tema (TOLEDO, Cláudia. op. cit.). São as seguintes as considerações do autor: "Não passou despercebido de alguns doutrinadores brasileiros mais modernos o problema sempre presente da ponderação de interesses divergentes, em uma constituição que consagra imperativos de transformação social, por meio da produção normativa, e um Estado do Bem-Estar Social. Nesse ponto, some-se, ainda, a dificuldade de sistematizar os critérios para se aceitar a oponibilidade dos direitos adquiridos perante as leis
} 
aceita pelo STF, porém a proteção do direito adquirido está assentada no cânone hermenêutico da segurança jurídica, do qual os demais princípios não se podem afastar. A experiência dos processualistas com a relativização da coisa julgada, de que se tratará adiante, prova que não se poderia adotar um critério geral que desconsiderasse o direito adquirido, depois de formado, mesmo que em prol dos mais valorosos princípios.

\subsubsection{O paralelo com as teorias processuais de relativização da coisa julgada}

Necessário reconhecer que os processualistas já caminharam bastante no tema da relativização da coisa julgada, o que, em certa medida - resguardadas as peculiaridades da natureza processual desta -, poderia ser estendido também ao direito adquirido.

Baseado em longa pesquisa doutrinária e em precedentes judiciais norte-americanos, Cândido Rangel Dinamarco argumenta que, se contiver a sentença "enunciados juridicamente impossíveis", inexistirá a coisa julgada material. Como exemplo, cita a decisão que "declarasse o recesso de um Estado federado, dispensando-o de prosseguir integrado na República Federativa do Brasil"268. Pondera que, "como a coisa julgada não é em si mesma um efeito e não tem dimensão própria, mas a dimensão dos efeitos substanciais da sentença sobre a qual incida (...), é natural que ela não se imponha quando os efeitos programados na sentença não tiverem condições de impor-se"269.

Em adição, sustenta que, assim como qualquer outra garantia, a coisa julgada não tem caráter absoluto. Afirma que "não há uma garantia sequer, nem mesmo a da coisa julgada, que conduza invariavelmente e de modo absoluto à renegação das demais ou dos valores

de ordem pública. (...) Dentro desse contexto, Cláudia Toledo reconhece o princípio do direito adquirido. Para essa doutrinadora, há tensão dialética entre o princípio do direito adquirido e o princípio do efeito imediato da lei nova, considerados por Cláudia Toledo como dois princípios fundamentais do Estado Democrático de Direito. Não seria possível estabelecer a priori solução para todos os conflitos de lei no tempo. Para a adequada solução de cada caso concreto seria absolutamente necessário recorrer à aplicação do princípio da proporcionalidade.

No entanto, no ponto central de sua teoria, não concordamos com a eminente doutrinadora. Não acreditamos que o direito adquirido seja um verdadeiro princípio, na acepção de Ronald Dworkin ou Robert Alexy. Trata-se, na verdade, de uma regra que visa a proteção da segurança jurídica, esta sim um princípio, um valor a ser protegido. Em um determinado caso concreto, ou existe direito adquirido, o qual deve ser protegido, ou inexiste direito adquirido. É um limite objetivo à aplicação retroativa ou retrospectiva da lei. É tudo ou nada".

${ }^{268}$ in DINAMARCO, Cândido Rangel. op. cit., p. 26.

${ }^{269}$ Id. Ibid. 
que elas representam. Afirmar o valor da segurança jurídica (ou certeza) não pode implicar desprezo ao da unidade federativa, ao da dignidade humana e intangibilidade do corpo etc." ${ }^{270}$.

Sob tais fundamentos - aqui resumidos em uma apertada síntese -, Cândido Rangel Dinamarco defende uma flexibilização da coisa julgada, ponderando, entretanto, que a relativização só deverá ocorrer em situações "extraordinárias e raras":

“(...) não estou a postular a sistemática desvalorização da auctoritas rei juricatce mas apenas o cuidado para situações extraordinárias e raras, a serem tratadas mediante critérios extraordinários. Cabe aos juízes de todos os graus jurisdicionais a tarefa de descoberta das extraordinariedades que devam conduzir a flexibilizar a garantia da coisa julgada, recusando-se a flexibilizá-la sempre que o caso não seja portador de absurdos, injustiças graves, transgressões constitucionais etc. Não temo insistir no óbvio, ao repetir que 'o momento de decisão de cada caso concreto é sempre o momento valorativo",271.

Busca, segundo diz, a harmonização entre princípios e garantias constitucionais, de modo a que não "se eternizem injustiças a pretexto de não eternizar litígios"272. A conclusão do autor é a seguinte:

\footnotetext{
"Se tiver razão no que sustento, terei chegado a uma visão sistemática da relativização da coisa julgada segundo critérios que em primeiro plano são objetivos - despontando sobretudo o da prevalência de certos valores, constitucionalmente resguardados tanto quanto a coisa julgada, os quais devem prevalecer mesmo com algum prejuízo para a segurança das relações jurídicas. Daí aceitar a idéia da coisa julgada inconstitucional, que assenta na premissa da harmoniosa convivência entre todos os princípios e garantias plantados na ordem constitucional, nenhum dos quais pode ser tratado como absoluto. A posição defendida tem apoio também no equilíbrio, que há muito venho postulando, entre duas exigências que a autoridade da coisa julgada prestigia, e a de justiça e legitimidade das decisões, que aconselha não radicalizar essa autoridade. Nessa linha, repito: a ordem constitucional não tolera que se eternizem injustiças a pretexto de não eternizar litígios"273.
}

\footnotetext{
${ }^{270}$ DINAMARCO, Cândido Rangel. op. cit., p. 28.

${ }^{271}$ Id. Ibid., p. 33.

${ }^{272}$ Id. Ibid., p. 36.

${ }^{273}$ Id. Ibid.
} 
Em linha de pensamento análoga ${ }^{274}$, Teresa Arruda Alvim Wambier e José Miguel Garcia Medina sustentam que haveria certas sentenças sem aptidão para transitar em julgado, que denominam de "sentenças juridicamente inexistentes" $" 275$. Como exemplo, citam as “sentenças proferidas em processos gerados pela propositura de 'ações', sem que tenham sido preenchidas as condições de seu exercício",276.

Relembrando o exemplo de Cândido Rangel Dinamarco, do Estado federado excluído da República Federativa do Brasil, argumentam que aí não haveria coisa julgada em razão de "impossibilidade jurídica do pedido", concluindo o seguinte:

"Pensamos que, em casos assim, houve sentenças proferidas em processos que se instauraram apesar da falta de possibilidade jurídica do pedido e que, assim como ocorre quando ausente uma das outras condições da ação, consiste em sentença juridicamente inexistente.

Este nos parece o meio mais seguro, e portanto o mais adequado, de explicar-se o fenômeno jurídico que ocorre nestes casos.

Parece-nos, então, dever optar-se por caminho ligeiramente diferente daquele proposto por Cândido Dinamarco, focalizando, em casos citados e em tantos outros, ausência de condição da ação (...)"277.

Por sua vez, Nelson Nery Junior ${ }^{278}$ ataca duramente as teorias de relativização da coisa julgada. Em texto bastante substancioso, o abalizado autor demonstra que, sendo a coisa julgada um dos pilares do Estado Democrático de Direito, sua desconsideração - mormente quando autorizada pelos magistrados de primeiro grau - poria em cheque todo o sistema, abrindo brechas à instauração de ditaduras totalitaristas. Merecem destaque alguns trechos do contundente artigo:

"Para as atividades do Poder Judiciário, a manifestação do princípio do Estado democrático de direito ocorre por intermédio do instituto da coisa julgada. (...)

\section{(...)}

\footnotetext{
${ }^{274} \mathrm{Na}$ mesma linha de pensamento, Humberto Theodoro Júnior e Juliana Cordeiro de Faria (in THEODORO JÚNIOR, Humberto; FARIA, Juliana Cordeiro de. A coisa julgada institucional e os instrumentos processuais para seu controle. Revista dos Tribunais, São Paulo, v. 91, n. 795, p. 21-40, jan. 2002).

${ }^{275}$ in WAMBIER, Teresa Arruda Alvim; MEDINA, José Miguel Garcia. O dogma da coisa julgada: hipóteses de relativização. São Paulo: Ed. Revista dos Tribunais, 2003. p. 26.

${ }^{276}$ Id. Ibid., p. 31.

${ }^{277}$ Id. Ibid., p. 35-36.

${ }^{278}$ in NERY JÚNIOR, Nelson. op. cit., p. 141-159.
} 
O que não parece ser admissível, data maxima venia, é cometer ao juiz comum, de primeiro ou segundo grau, não importa, a tarefa de dizer se a sentença de seu colega (juízo ou tribunal) fez ou não coisa julgada porque inconstitucional ou injusta. É este, em suma, o resultado da aceitação e aplicação da tese da desconsideração da coisa julgada: qualquer juízo singular poderia declarar que não houve coisa julgada ou destruí-la, ignorá-la, ao argumento de que teria sido formada contra o texto da Constituição ou com injustiça manifesta. É o nascimento do caos.

Dizer que a relativização ocorreria apenas em casos excepcionais é o canto da sereia. (...)

A história recente do processo civil brasileiro mostra, com clareza meridiana, que a exceção virou regra em face do 'jeitinho brasileiro'.

Com a coisa julgada 'relativizada' o fenômeno, sem dúvida, se repetirá. As 'exceções' do primeiro momento, virarão 'regra' e a coisa julgada material somente será intangível para pobres e excluídos, pois os ricos e os poderosos terão meios para fazer valer a tese da relativização e as decisões judiciais transitadas em julgado não mais os atingirão. Não é para isso que se presta o processo. Prestigiar a tese da desconsideração da coisa julgada material é avalizar o nazismo processual.

Por esses motivos, basicamente, é que ao final deste estudo propomos soluções de lege ferenda, que decorrem do respeito ao Estado Democrático de Direito, visando solucionar as hipóteses de extrema exceção, repetimos, que não podem ser pretexto para que se crie regra que desatenda ao texto da Constituição Federal. Resolver problemas sim. Mas com responsabilidade, sem vestir um santo para desvestir outro; com respeito ao sistema constitucional brasileiro, ao Estado Democrático de Direito. O processo é instrumento da democracia e não o seu algoz. Não se pode utilizar o processo como instrumento (consciente ou não, propositado ou não) nazista",279.

A ponderação procede e demonstra não se poder adotar critério que simplesmente desconsidere a proteção do direito adquirido. Contudo, as diferenças que há entre a coisa julgada e o direito adquirido impedem-nos de abraçar a crítica inteiramente, levando-nos a importar a idéia de que, por contrariar o sistema jurídico, certos fatos dão azo a direitos meramente aparentes, que não obstam a aplicação da lei nova pelo Juiz.

Se a coisa julgada não poderia ser utilizada para acobertar sentenças inexistentes, o direito intertemporal não poderia agasalhar atos imperfeitos e direitos aparentes, blindando negócios inválidos que não têm e não devem receber proteção contra o advento de lei nova que os expressamente proíba.

\footnotetext{
${ }^{279}$ NERY JÚNIOR, Nelson. op. cit., p. 142 e 144.
} 


\title{
4.2.4. $O$ critério que propomos - a ponderação na origem
}

“(...) a atitude positivista implica uma orientação reacionária, pois, se aplicada - e, na verdade, povo culto nenhum jamais a aplicou restritivamente -, tolheria a natural evolução do Direito, gradativamente levada a cabo pela Doutrina e pela Jurisprudência, no seu cotidiano afã de adaptar as normas gerais do Sistema à multifacetária casuística das relações da vida" (Rubens Limongi França) ${ }^{280}$.

Como se viu no item 4.2.1, a norma de ordem pública não pode afastar a proteção do direito adquirido, depois que este já tiver se formado, pois isto representaria afronta ao artigo $5^{\circ}$, inciso XXXVI, da Constituição Federal. Contudo, é necessário observar que, quando se está diante de norma de ordem pública, dificilmente terá havido aquisição de direito ou ato jurídico perfeito, sem os quais não existem óbices à incidência imediata da lei nova.

Isso se dá porque muitas leis de ordem pública vêm apenas explicitar princípios que já estavam presentes no sistema jurídico, os quais impediam a aquisição do direito mesmo à míngua de lei em contrário. A aquisição de direitos deve considerar todo o sistema jurídico e não apenas a letra da lei, a qual muitas vezes tolera abusos que os princípios combatem. Como ensina o douto Desembargador Cláudio Antônio Soares Levada,

\begin{abstract}
"a noção de ilícito não se confunde com a de ilegal, esta limitando-se à contrariedade à lei, enquanto aquela é abrangente não apenas da normaregra, mas também da norma-princípio, cuja dimensão axiológica é muito maior - tenha-se em mente, por mero exemplo, o ilícito por lesão à boafé, ou aos bons costumes, aspectos que não se confundem de nenhum modo com a lesão à letra da lei",281.
\end{abstract}

Por sua vez, o que é considerado abusivo não poderá dar azo a direito adquirido, pois o sistema jurídico não poderia permitir a intangibilidade de uma prática ilícita e contrária aos seus fundamentos, mesmo que a lei não a condenasse. O Juiz deverá decretar a nulidade do ato, tenha ele ocorrido antes ou depois de lei que o venha coibir expressamente - não poderá

\footnotetext{
${ }^{280}$ in FRANÇA, Rubens Limongi. Princípios gerais de direito. 2. ed. São Paulo: Ed. Revista dos Tribunais, 1971. p. 160

${ }^{281}$ in LEVADA, Cláudio Antônio Soares. O abuso e o novo direito civil brasileiro. 2006. Tese (Doutorado) Faculdade de Direito, Pontifícia Universidade Católica de São Paulo, São Paulo, 2006. Disponível em: $<\mathrm{http}$ ://www.sapientia.pucsp.br/tde_busca/arquivo.php?codArquivo=1862>. Publicada em livro homônimo, O abuso e o novo direito civil brasileiro. Jundiaí: Ed. Unianchieta, 2007. p. 14.
} 
a parte alegar direito adquirido para obstar a aplicação da lei nova, proibitiva, tendo em vista que o ato já poderia ser considerado um não-direito antes de seu advento.

Por esta razão, dizemos que, ao julgar o caso concreto, o Juiz deverá realizar uma ponderação na origem, analisando se a lei nova realmente contraria direito adquirido ou se este já não poderia ser decretado nulo desde o seu nascimento. O Juiz não pode permitir que o direito intertemporal seja utilizado para agasalhar atos imperfeitos e direitos aparentes, blindando negócios inválidos que não têm e não devem receber proteção contra o advento de lei nova que os expressamente proíba.

Quer-se dizer, em resumo, que o Juiz não deverá contrapor o direito adquirido à ordem pública, realizando uma ponderação valorativa posterior à formação do direito. Ao contrário, o Juiz deverá ponderar na origem (no nascimento do direito), perscrutando se, levados em conta os princípios do sistema jurídico, o direito havia se formado ou era meramente aparente, caso em que a norma nova deverá ter aplicação imediata independentemente de sua natureza.

Alguns exemplos deixarão clara a questão. Vejamos o primeiro: em 11 de março de 1991, entrou em vigor o Código de Defesa do Consumidor, Lei $\mathrm{n}^{\circ}$ 8.078/90, o qual proibiu a instituição do pacto que autorizava a perda, em favor do vendedor, de todas as prestações pagas pelo comprador inadimplente (artigo 53).

A proibição levou milhares de consumidores a requerer a aplicação do dispositivo a contratos em curso, sustentando que o Código de Defesa do Consumidor seria norma de ordem pública e afastaria, pois, a proteção do direito adquirido. Levada ao Superior Tribunal de Justiça ${ }^{282}$, a pretensão acabou repelida, por maioria, prevalecendo a tese de que as normas de ordem pública não se sobrepõem aos artigos $5^{\circ}$, inciso XXXVI, da Constituição Federal, e $6^{\circ}$ da Lei de Introdução ao Código Civil. Relatada pelo Ministro Barros Monteiro, a decisão acabou assim ementada:

"PROMESSA DE VENDA E COMPRA. CLÁUSULA PENAL ESTABELECENDO A PERDA DAS QUANTIAS PAGAS PELO COMPROMISSÁRIO-COMPRADOR. ART. 53 DA LEI N ${ }^{\circ}$ 8.078, DE 11.9.1990.

Inaplicabilidade do art. 53 da Lei $\mathrm{n}^{\circ} 8.078 / 90$ aos contratos celebrados antes da vigência do mencionado diploma legal. Precedentes do STJ".

\footnotetext{
${ }^{282}$ STJ, 4 a Turma, Recurso Especial no 45.666/SP, Rel. Min. Barros Monteiro, j. 17.5.1994, votação por maioria.
} 
Contudo, em brilhante voto vencido, o Ministro Ruy Rosado de Aguiar notou que a questão não poderia ser decidida pela dicotomia direito adquirido versus ordem pública, pois não era adquirido um direito que, mesmo antes do Código de Defesa do Consumidor, já estava vedado por princípios do sistema jurídico nacional. Não sendo adquirido - mas um direito meramente aparente -, o Código de Defesa do Consumidor deveria ser aplicado às relações em curso, independentemente de sua natureza.

Valendo-se da lição de Alcides Tomasetti Jr. ${ }^{283}$, o ilustre Ministro afirmou que

"No contrato de compra e venda de bem imóvel, a cláusula contratual que determina a perda, em favor do promitente vendedor, das prestações pagas, caracteriza nítida perda de justiça por parte do promissário comprador, que não apenas vê desaparecer a oportunidade de aquisição do bem, já certamente mais valorizado do que qualquer moeda, nestes tempos de inflação, como ainda deixa de receber a devolução do que desembolsou. Além da injustiça, ainda há a ofensa aos princípios jurídicos que regulam a resolução, cuja característica está na reposição das partes à situação anterior. Reavendo o bem e embolsando os pagamentos recebidos, o promitente vendedor não só recompõe o seu patrimônio como o enriquece ilicitamente com as prestações, em troca das quais nada despendeu.

Com isso quero dizer que a cláusula de decaimento não podia ter reconhecida sua validade no sistema jurídico nacional, ainda antes da vigência do Código do Consumidor, porque violadora de diversos princípios de direito comum e do ordenamento constitucional, como o demonstrou o Prof. Alcides Tomasetti Jr. (Revista Direito do Consumidor, 2/52).

O artigo 53 do Código de Defesa do Consumidor veio apenas expressar um enunciado que já estava presente no ordenamento e era aplicado sempre que necessário para restabelecer o equilíbrio entre as partes, afastar a vigência de cláusulas resultante do arbítrio de uma, em prejuízo de outra, impor o respeito ao princípio da boa-fé e fazer cumprir o de solidariedade social (art. 3, I, da CF).

\section{(...)}

Diz-se que a aplicação a contrato assinado antes de sua vigência significaria violação ao princípios da irretroatividade da lei, assim como expresso na Constituição da República. Ocorre que, tanto agora como antes, não há como admitir um direito subjetivo fundado em cláusula iníqua, nem a validade de ato negocial onde se manifesta o arbítrio de uma das partes, com exercício abusivo de direito".

\footnotetext{
${ }^{283}$ in TOMASETTI JÚNIOR, Alcides. Aspectos da proteção contratual do consumidor no mercado imobiliário urbano. Rejeição das clausulas abusivas pelo direito comum. Revista de Direito do Consumidor, São Paulo, n. 2, p. 52-66, mar. 1992.
} 
Sem se render à irretroatividade das normas de ordem pública, o Ministro Ruy Rosado de Aguiar realizou ponderação na origem, concluindo que o Código de Defesa do Consumidor apenas explicitou a antijuridicidade da cláusula de decaimento - que, se não é direito, não impede a incidência da lei nova. Conforme demonstrou, a abusividade da cláusula não passou a existir apenas com o advento da legislação de consumo, mas, sim, porque fere princípios e permite o enriquecimento ilícito, que o sistema jurídico coíbe, desde sempre, independentemente de lei nesse sentido.

Vejamos o segundo exemplo: em $1^{\text {o }}$ de janeiro de 2004, entrou em vigor o Estatuto do Idoso, Lei no 10.741/2003, cujo artigo 15, § 3º veda "a discriminação do idoso nos planos de saúde pela cobrança de valores diferenciados em razão da idade", contrariando o artigo 15 da legislação dos planos e seguros de saúde, Lei no 9.656/98, que permitia "a variação das contraprestações pecuniárias estabelecidas nos contratos de planos e seguros (...) em razão da idade do consumidor".

Como esta norma, Lei $\mathrm{n}^{\circ}$ 9.656/98, facultava o trato discriminatório entre idosos e não-idosos, a grande maioria dos contratos de plano de saúde possuía, no dia da entrada em vigor da Lei $n^{\circ} 10.741 / 2003$, cláusula prevendo reajuste exorbitante quando o segurado completasse 60 anos de idade, suscitando a questão: a Lei ${ }^{\circ} 10.741 / 2003$, que institui o Estatuto do Idoso, seria aplicável aos contratos de plano de saúde em curso?

A discussão foi objeto de recurso perante o Superior Tribunal de Justiça ${ }^{284}$, onde as operadoras de plano de saúde sustentaram que a aplicação imediata do Estatuto do Idoso, inclusive aos contratos em curso, feriria o direito adquirido e o ato jurídico perfeito, contrariando o artigo $5^{\circ}$, inciso XXXVI, da Constituição Federal, e o artigo $6^{\circ}$ da Lei de Introdução ao Código Civil. De outro lado, alegou-se ser abusiva a cláusula que impõe aumento de 164, 91\% em razão da idade.

Distribuído o recurso à Terceira Turma do Superior Tribunal de Justiça, foi designada relatora a Ministra Nancy Andrighi, que decidiu não haver direito adquirido ao reajuste contratualmente previsto, pois a cláusula de reajuste exorbitante em razão da idade já poderia ser considerada abusiva antes do Estatuto do Idoso, por afronta a princípios contidos em

\footnotetext{
${ }^{284}$ STJ, $3^{\text {a }}$ Turma, REsp no 809.329/RJ, Rel. Min. Nancy Andrighi, j. 25.3.2008, votação por maioria.
} 
dispositivos legais e constitucionais anteriores ao seu advento. Quanto ao ponto, afirmou a Ministra Nancy Andrighi ${ }^{285}$ :

"Sob tal encadeamento lógico, o consumidor que atingiu a idade de 60 anos, quer seja antes da vigência do Estatuto do Idoso, quer seja a partir de sua vigência ( $1^{\circ}$ de janeiro de 2004$)$, está sempre amparado contra a abusividade de reajustes das mensalidades dos planos de saúde com base exclusivamente no alçar da idade de 60 anos, pelo própria proteção conferida pela Lei dos Planos de Saúde e, ainda, por efeito reflexo da Constituição Federal que estabelece norma de defesa do idoso no art. 230.

Partindo da premissa posta no acórdão impugnado de que a recorrida completou 60 anos na vigência do Estatuto do Idoso, por certo, deve ser-lhe conferida a proteção especial garantida pela Lei nova, sem descurar das salvaguardas aos idosos tais como traçadas em dispositivos legais infraconstitucionais e constitucionais, que já concediam tutela de semelhante jaez, agora robustecida pela Lei recente".

Em sentido contrário, votaram os Ministros Castro Filho e Humberto Gomes de Barros.

Prevaleceu, no entanto, a tese defendida pela Ministra Nancy Andrighi, acompanhada pelos Ministros Sidnei Beneti e Ari Pargendler. O julgado restou assim ementado:

"Direito civil e processual civil. Recurso especial. Ação revisional de contrato de plano de saúde. Reajuste em decorrência de mudança de faixa etária. Estatuto do idoso. Vedada a discriminação em razão da idade.

- O Estatuto do Idoso veda a discriminação da pessoa idosa com a cobrança de valores diferenciados em razão da idade (art. 15, § $3^{\circ}$ ).

- Se o implemento da idade, que confere à pessoa a condição jurídica de idosa, realizou-se sob a égide do Estatuto do Idoso, não estará o consumidor usuário do plano de saúde sujeito ao reajuste estipulado no contrato, por mudança de faixa etária.

- A previsão de reajuste contida na cláusula depende de um elemento básico prescrito na lei e o contrato só poderá operar seus efeitos no tocante à majoração das mensalidades do plano de saúde, quando satisfeita a condição contratual e legal, qual seja, o implemento da idade de 60 anos.

- Enquanto o contratante não atinge o patamar etário preestabelecido, os efeitos da cláusula permanecem condicionados a evento futuro e incerto, não se caracterizando o ato jurídico perfeito, tampouco se configurando o

\footnotetext{
${ }^{285}$ A douta Magistrada afirmou também, mas a nosso ver de maneira equivocada, que, estando a cláusula de reajuste subordinada a evento futuro e incerto, só haveria direito adquirido no dia em que o segurado completasse 60 anos de idade. Embora, a rigor, só haja aquisição do direito condicionado quando da implementação do evento contratualmente previsto, o artigo $6^{\circ}, \S 2^{\circ}$, da Lei de Introdução ao Código Civil, equipara a condição suspensiva a direitos adquiridos, conforme explanamos no item 3.3.1.2.
} 
direito adquirido da empresa seguradora, qual seja, de receber os valores de acordo com o reajuste predefinido.

- Apenas como reforço argumentativo, porquanto não prequestionada a matéria jurídica, ressalte-se que o art. 15 da Lei n. ${ }^{\circ}$ 9.656/98 faculta a variação das contraprestações pecuniárias estabelecidas nos contratos de planos de saúde em razão da idade do consumidor, desde que estejam previstas no contrato inicial as faixas etárias e os percentuais de reajuste incidentes em cada uma delas, conforme normas expedidas pela ANS. No entanto, o próprio parágrafo único do aludido dispositivo legal veda tal variação para consumidores com idade superior a 60 anos.

- E mesmo para os contratos celebrados anteriormente à vigência da Lei n. ${ }^{\circ}$ 9.656/98, qualquer variação na contraprestação pecuniária para consumidores com mais de 60 anos de idade está sujeita à autorização prévia da ANS (art. 35-E da Lei n. ${ }^{\circ}$ 9.656/98).

- Sob tal encadeamento lógico, o consumidor que atingiu a idade de 60 anos, quer seja antes da vigência do Estatuto do Idoso, quer seja a partir de sua vigência ( $1^{\circ}$ de janeiro de 2004), está sempre amparado contra a abusividade de reajustes das mensalidades com base exclusivamente no alçar da idade de 60 anos, pela própria proteção oferecida pela Lei dos Planos de Saúde e, ainda, por efeito reflexo da Constituição Federal que estabelece norma de defesa do idoso no art. 230.

- A abusividade na variação das contraprestações pecuniárias deverá ser aferida em cada caso concreto, diante dos elementos que o Tribunal de origem dispuser.

- Por fim, destaque-se que não se está aqui alçando o idoso a condição que o coloque à margem do sistema privado de planos de assistência à saúde, porquanto estará ele sujeito a todo o regramento emanado em lei e decorrente das estipulações em contratos que entabular, ressalvada a constatação de abusividade que, como em qualquer contrato de consumo que busca primordialmente o equilíbrio entre as partes, restará afastada por norma de ordem pública.

Recurso especial não conhecido".

Como se vê, também aqui - e desta vez majoritariamente - julgou-se pela aplicação imediata da lei sem se ter de recorrer à dicotomia direito adquirido versus ordem pública. Decidiu-se, ao contrário, que não houvera aquisição de direito, razão pela qual não haveria óbices à incidência imediata da nova norma. Houve ponderação na origem, com a conclusão de que a cláusula de reajuste exorbitante configura um ato imperfeito, gerando um direito meramente aparente. Percebeu-se que esta cláusula não veio a ser proibida apenas porque o Estatuto do Idoso a coibiu, mas porque tal estipulação, apesar de até então permitida em 
lei, afronta os mais comezinhos princípios constitucionais - sendo, pois, abusiva e iníqua, sem condão de gerar direito adquirido ou ato jurídico perfeito.

Vejamos o terceiro e último exemplo: em 10 de abril de 2007, entrou em vigor no Município de Florínea, no Estado de São Paulo, a Lei Complementar nº 208/2007, que coíbe a prática do nepotismo, proibindo a nomeação de cônjuges, companheiros e parentes na linha reta ou colateral, até o terceiro grau, de Prefeito, Vice-Prefeito e Vereadores do Município, para cargos comissionados na Administração Direta ou Indireta - determinando que "os contratados, nomeados ou admitidos, sob qualquer título, anteriormente à vigência da lei (...) serão exonerados, demitidos e ou rescindidos seus contratos, no prazo máximo de 30 dias, contados da entrada em vigor da lei" (artigo $2^{\circ}$ ).

Não se conformando com a demissão dos familiares, o Prefeito daquele Município ajuizou ação direta de inconstitucionalidade perante o Tribunal de Justiça do Estado de São Paulo $^{286}$, alegando que a Lei Complementar $n^{\circ}$ 208/2007 ofenderia pretenso direito adquirido a continuar contratado nepoticamente.

Por outro lado, a Câmara Municipal informou que a Lei Complementar nº 208/2007 “de forma elogiosa e pedagógica, enalteceu os princípios constitucionais republicanos da isonomia, da moralidade e da impessoalidade, obrigatórios no trato da Administração Pública com a gestão dos interesses públicos e sociais a cargo do servidor investido nos termos da lei”.

Distribuído o feito ao Órgão Especial do Tribunal de Justiça de São Paulo, foi sorteado à relatoria do caso o Desembargador Henrique Nelson Calandra, que julgava a ação procedente por vício de iniciativa e por entender que, ao determinar a demissão de servidores já contratados, a Lei Complementar no 208/2007 afrontaria o ato jurídico perfeito. Destaca-se este trecho do voto do Desembargador Henrique Nelson Calandra:

"Por outro lado, a lei complementar em questão, dispõe em seu art. $2^{\circ}$ que
os contratados, nomeados ou admitidos, sob qualquer título,
anteriormente à vigência da lei, e que tiverem incorrido nas proibições do
art. $1^{\circ}$, serão exonerados, demitidos e ou rescindidos seus contratos, no prazo
máximo de 30 dias, contados da entrada em vigor da lei.

Tal dispositivo afronta o art. $5^{\circ}$, XXXVI, da Constituição Federal, que garante o direito adquirido, o ato jurídico perfeito e a coisa julgada. A lei alcançará sua plena vigência e eficácia ao ser publicada, sendo que seus efeitos são para o futuro, aplicando-se a regra 'tempus regit actum', segundo

${ }^{286} \mathrm{TJ} / \mathrm{SP}$, Órgão Especial, ADin Estadual no 148.484-0/8-00, Rel. designado para acórdão Des. José Luís Palma Bisson, j. 2.4.2008, votação por maioria. 
a qual fatos já ocorridos e situações já consumadas no passado não se regem pela nova lei que entra em vigor, mas continuam valorados segundo a lei do seu tempo".

Em contrapartida, os Desembargadores Walter Guilherme, Marco César e Canguçu de Almeida julgaram a ação improcedente, sob o entendimento de que a Lei Complementar n $208 / 2007$ estaria em consonância com os princípios da moralidade, impessoalidade, publicidade, razoabilidade, finalidade, motivação e interesse público. Em voto lapidar, o Desembargador José Luís Palma Bisson, designado para relatar a tese vencedora, argumentou que a contratação contrária aos princípios da Administração Pública não gera direito adquirido para os familiares, nem configura ato jurídico perfeito. São seus principais os argumentos:

“(...) verdade que o art. $5^{\circ}$, XXXVI, da Constituição Federal, garante o direito adquirido, o ato jurídico perfeito e a coisa julgada, como também que a lei alcançará sua plena vigência e eficácia após ter sido promulga e publicada, sendo que seus efeitos são para o futuro, aplicando-se a regra tempus regit actum.

Porém, desde que ocorrida à custa da violação dos princípios que devem reger a Administração Pública, não se configura perfeita a contratação de parentes, nem adquirido se apresenta o direito destes permanecerem contratados, pois ilegal ao revés já se desenha o ato, independentemente da consideração de ser retroativo o efeito da lei que o proíbe (...).

\section{(...)}

Portanto, ofensa não haverá se o fato for incapaz de gerar direito, porque inidôneo em face dos preceitos da lei vigente ao tempo em que ocorreu.

É esse o caso, justamente.

A lei em comento, como tantas outras semelhantes, na coibição inclusive do nepotismo, que foram julgadas constitucionais por este Plenário, nem à luz do art. $5^{\circ}$, XXXVI, da Constituição Federal inconstitucional se mostra, porquanto contratar parentes o administrador público imoral ou inidôneo segundo os preceitos da Magna Carta por si só já é a ponto de não gerar ato jurídico perfeito, tampouco direito com feição de adquirido, que aquela então, no mais que proibir, coibindo, nem de leve ofende".

$\mathrm{O}$ voto vencedor restou assim ementado:

"Ação direta de inconstitucionalidade - Lei Complementar do Município de Florínea, de $\mathrm{n}^{\circ}$ 208, de 10 de abril de 2007, que, por vereadora iniciativa, derribado o veto do Prefeito, institui a proibição do nepotismo e 
ainda coíbe, mediante a imposição de serem exonerados, demitidos ou verem rescindidos seus contratos, os contratados ou admitidos sob qualquer título e que estiverem incursos nas proibições dela, ressalvados expressamente os servidores públicos admitidos por concurso público - não padece de inconstitucionalidade lei municipal que, de vereadora iniciativa, proíbe a prática do nepotismo, haja vista tratar-se de matéria moralizadora da Administração e editada em consonância com os princípios constitucionais que regem a Administração Pública - na coibição inclusive do nepotismo, nem à luz do artigo $5^{\circ}$, XXXVI, da Constituição Federal, inconstitucional se mostra a lei municipal em apreço, porquanto contratar parentes o administrador público imoral ou inidôneo segundo os preceitos da Magna Carta por si só já é a ponto de não gerar ato jurídico perfeito, tampouco direito com feição de adquirido, que aquela então, no mais que proibir, coibindo, nem de leve ofende - ação improcedente".

Como se vê, mais uma vez julgou-se pela incidência imediata da lei nova sem se ter de recorrer à dicotomia direito adquirido versus ordem pública. Decidiu-se, ao revés, que se não havia configurado in casu direito adquirido, razão pela qual a norma, independentemente de sua natureza, deveria incidir sobre todas as relações em curso. Houve ponderação na origem, com a conclusão de que a lei nova apenas explicitara o que o sistema jurídico já proclamava: certos atos são imperfeitos e alguns direitos apenas aparentes, não recebendo proteção contra a lei nova. O nepotismo não veio a ser proibido no Município de Florínea porque a lei o coibiu, mas porque tal prática, apesar de não vedada em lei, sempre se mostrou imoral e condenável - e, portanto, ilícita, sem condão de gerar direito adquirido ou ato jurídico perfeito. 


\section{QUINTA PARTE. O DIREITO INTERTEMPORAL APLICADO - AS PRINCIPAIS CONTROVÉRSIAS NO DIREITO CIVIL}

\subsection{Parte Geral}

\subsubsection{A alteração da capacidade civil, aos dezoito anos - o artigo $5^{\circ}$, caput, do Código} Civil de 2002

Pelo Código Civil de 1916, a menoridade cessava aos 21 anos completos. Dispunha o artigo $9^{\circ}$, caput:

"Art. 9 . Aos 21 (vinte e um) anos completos acaba a menoridade, ficando habilitado o indivíduo para todos os atos da vida civil".

Por sua vez, o Código Civil de 2002 dispôs que a menoridade cessa ao se completar 18 anos. Prevê o artigo $5^{\circ}$, caput:

"Art. $5^{\circ}$. A menoridade cessa aos 18 (dezoito) anos completos, quando a pessoa fica habilitada à pratica de todos os atos da vida civil".

Com a alteração, as pessoas com mais de 18 anos em 11 de janeiro de 2003 passaram a ser plenamente capazes, pois a lei que atribui capacidade não encontra óbices no ato jurídico perfeito, no direito adquirido ou na coisa julgada, aplicando-se desde logo, do início de sua vigência em diante, a todos os fatos em curso.

Como ensina Carlos Francesco Gabba, “(...) as leis concernentes ao estado e à capacidade das pessoas devem (...) ser aplicadas imediatamente a todas as pessoas que se encontrem na condição nela contemplada, e não somente àquelas que venham a estar em tal condição no futuro (...)"287.

\footnotetext{
${ }^{287}$ GABBA, Carlos Francesco. op. cit., v. 2, p. 16. Tradução livre de: “(...) le leggi concernenti lo stato e la capacità delle persone debbano (...) applicarsi immediatamente a tutte le persone che si trovano nelle condizioni contemplate da esse leggi, e non soltanto a quelle che entraranno in tali condizioni in avvenire (...)". Diferentemente, se a lei nova houvesse aumentado a idade em que se adquire a capacidade plena, esta lei não poderia retirar a capacidade já adquirida. Esta a lição de Carlos Francesco Gabba: "É verdade que as leis sobre estado das pessoas são imperativas, e não dispositivas, que os direitos referentes ao estado
} 
Também em 11 de janeiro de 2003 cessaram, em relação a essas pessoas, as proibições, faculdades e deveres decorrentes da incapacidade civil, tendo em vista que estes são disciplinados pela lei vigente ao tempo em que se desenvolverem, por não gozarem da mesma proteção conferida ao ato jurídico perfeito, ao direito adquirido e à coisa julgada (item 3.5.2). Assim, por exemplo, o alimentante poderá pedir exoneração dos alimentos devidos em razão do poder familiar se o alimentando tiver mais de dezoito anos na data da entrada em vigor do Código Civil de 2002 (item 5.6.4).

Por outro lado, não se alteraram os deveres, obrigações e faculdades decorrentes não da incapacidade mas da idade. Por exemplo, o beneficiário da Previdência Social não perderá o benefício quando se tornar maior de idade, pois a Lei $n^{\circ} 8.213 / 91$ exige, para concessão deste, idade inferior a 21 anos, e não incapacidade civil (artigo 77); igualmente, o menor infrator com 18 anos em 11 de janeiro de 2003 não receberá a liberação compulsória, pois a Lei $n^{\circ} 8.069 / 90$ a confere com 21 anos, e não com a maioridade civil (artigo 121, § $\left.5^{\circ}\right)^{288}$.

\subsubsection{Aplicação "retroativa" dos novos vícios, estado de perigo e lesão - os artigos 156 e 157 do Código Civil de 2002}

Ao lado de erro (artigos 138 a 144), dolo (artigos 145 a 150), coação (artigos 151 a 155), fraude contra credores (artigos 158 a 165) e simulação - esta agora deslocada para o

\footnotetext{
pessoal são determinados pelo legislador segundo exigências da moral e do bem comum e não com a intenção de satisfazer interesses individuais, mas isto não leva a deduzir que tais leis, enquanto atribuem ao cidadão um estado pessoal vantajoso, não visem também a conferir uma vantagem pessoal decorrente de tal estado. Isto posto, aquele que houver adquirido um estado pessoal vantajoso terá realmente adquirido direito a este, e pode pretender que a lei nova o respeite, com não menos fundamento que aquele que pretende o respeito a qualquer outro direito adquirido, por exemplo os direitos adquiridos patrimoniais" (Id. Ibid., p. 37. Tradução livre de: "Egli è vero che le leggi sullo stato personale sono imperative, e non dispositive, che i diritti di stato personale sono determinati dal legislatore secondo le esigenze delle morale $e$ del pubblico bene, piuttosto che colla mira di soddisfare a individuali pretensioni, ma tutto ciò non equivale a dire, nè conduce a ritenere che tali leggi, in quanto attribuiscono al citadino uno stato personale vantaggioso, non mirino altersì a conferire a singole vantaggi di tale stato. Ciò posto, l'individuo il quale ha raggiunto uno stato personale vantaggioso, ha realmente acquistato un diritto al medesimo, e può pretendere che la legge nuova lo rispetti, con non minor fondamento di quello con cui egli pretende il rispetto di qualunque altro diritto acquisito, e per esempio dei diritti acquisiti patrimoniali"). $\mathrm{O}$ mesmo se diga quanto à validade dos atos praticados quando o sujeito era capaz, conforme esclarece o citado autor: “(...) abolida a capacidade de uma pessoa qualquer, a aplicação retroativa [efeito imediato] desta lei não pode retirar a validade nem a eficácia dos atos e negócios jurídicos praticados anteriormente com base naquela capacidade” (Id. Ibid., p. 30. Tradução livre de: “(...) abolita una capacità personale qualunque, l'applicazione retroattiva di questa legge non può togliere validità nè efficacia agli atti e negozi giuridici posti in essere precedentemente in virtù di quella capacità".

${ }^{288}$ Os exemplos são de Mário Luiz Delgado (in DELGADO, Mário Luiz. op. cit., p. 125-130).
} 
capítulo "da invalidade do negócio jurídico” (artigos 166 a 184) -, o Código Civil de 2002 disciplinou dois novos vícios do negócio jurídico, estado de perigo e lesão, artigos 156 e 157:

"Art. 156. Configura-se o estado de perigo quando alguém, premido da necessidade de salvar-se, ou a pessoa de sua família, de grave dano conhecido pela outra parte, assume obrigação excessivamente onerosa.

Parágrafo único. Tratando-se de pessoa não pertencente à família do declarante, o juiz decidirá segundo as circunstâncias".

"Art. 157. Ocorre a lesão quando uma pessoa, sob premente necessidade, ou por inexperiência, se obriga a prestação manifestamente desproporcional ao valor da prestação oposta.

$\S 1^{\circ}$. Aprecia-se a desproporção das prestações segundo os valores vigentes ao tempo em que foi celebrado o negócio jurídico.

$\S 2^{\circ}$. Não se decretará a anulação do negócio jurídico se for oferecido suplemento suficiente, ou se a parte favorecida concordar com a redução do proveito".

Indaga-se se os novos defeitos poderiam ser aplicados a negócios jurídicos celebrados antes do início da vigência do Código Civil de 2002.

Embora a validade dos negócios jurídicos deva ser aferida, em regra, de acordo com a lei vigente ao tempo de sua celebração, os artigos 156 e 157 do Código Civil de 2002 podem ser aplicados a relações anteriores ao seu advento, tendo em vista que o estado de perigo e a lesão já poderiam ser reconhecidos pelo Judiciário antes de 11 de janeiro de 2003.

Os negócios jurídicos eivados dos vícios do estado de perigo e da lesão são contrários aos princípios informadores do sistema jurídico, e não têm, pois, condão de configurar ato jurídico perfeito ou direito adquirido. Tais princípios já estavam presentes no sistema jurídico antes dos artigos 156 e 157 do Código Civil de 2002, os quais apenas tornaram expresso algo imanente: não são válidos os negócios jurídicos que firam a função social do contrato e a boa-fé objetiva, permitindo o enriquecimento ilícito.

Mesmo à míngua de lei em contrário, o Judiciário já considerava anuláveis as obrigações excessivamente onerosas contraídas sob premente necessidade de salvar-se, ou a pessoa de sua família (estado de perigo). Nesse sentido é o voto que segue, relatado pelo Desembargador Enio Zuliani, do Tribunal de Justiça de São Paulo: 
"Quando um hospital celebra contrato de prestação de serviços médicos hospitalares com pessoa de 73 anos de idade, não poderá inserir, para exonerar-se da obrigação, cláusula que exclui tratamento de doenças crônicas terminais ou geriátricas, porque esse tipo de regulamento atrofia a função social do contrato, prejudicando a expectativa do aderente de optar por outros contratos alternativos transparentes - Invalidade da cláusula por seu sentido abusivo. Se os terceiros pagam as contas exigidas pelo hospital para atender paciente com risco de vida, adquirem eles, pelo princípio jurídico que veda o enriquecimento sem causa, o direito de repetição do indébito, diante da inexigibilidade da dívida. Recurso provido com aplicação do art. 515, § 3o, do CPC, para julgar procedente a ação" ${ }^{\text {"289 }}$.

No mesmo sentido é o entendimento de Flávio Tartuce:

“(...) sendo conceito relacionado com a função social do contrato, pela conjugação das regras contidas nos arts. 157 e parágrafos, 421 e 2.035 , parágrafo único, do Código Civil, combinados com os arts. 5. ${ }^{\circ}$, XXII e XXIII, e 170, III, da CF/88, há plena possibilidade de anular ou de rever, judicialmente, negócio celebrado antes da vigência da atual codificação pela presença de lesão, vício que também repercute socialmente, conforme já definido neste trabalho" ${ }^{\text {, } 90}$.

Conforme sustentado nos itens 4.2.4 e 5.3.2, o direito intertemporal não pode ser utilizado para agasalhar atos imperfeitos e direitos aparentes, blindando atos jurídicos que não têm e não devem receber proteção contra o advento de lei nova que os expressamente proíba. Deve o Juiz realizar uma ponderação na origem, investigando se o direito realmente se havia formado ou se, mesmo antes da lei nova, o sistema jurídico já albergava princípios que impediam a aquisição. Os atos praticados em estado de perigo ou de forma lesiva são inválidos desde sempre, não configurando ato jurídico perfeito ou direito adquirido - e, por isto, não obstam a aplicação dos artigos 156 e 157 do Código Civil de 2002.

\subsubsection{A alteração de prazos prescricionais, em geral}

Ao extinguir a pretensão pelo decurso do tempo (artigo 189 do Código Civil de 2002), a prescrição se comporta como direito de aquisição por elementos dependentes (item 3.3.2.2), só se verificando quando da conjunção inércia + transcurso do tempo. Antes do prazo previsto

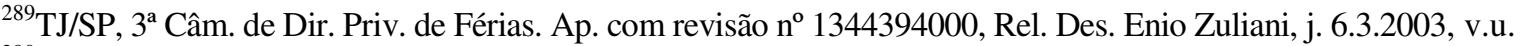
${ }^{290}$ TARTUCE, Flávio. Função social dos contratos: do Código de Defesa do Consumidor ao Código Civil de 2002. São Paulo: Método, 2007. p. 404. (Coleção Prof. Rubens Limongi França, v. 2).
} 
na lei, não ocorre a perda do direito à ação condenatória, nem a aquisição do tempo ainda por escoar.

Não existindo direito adquirido ao prazo escoado ou ao restante, a lei nova deverá ter aplicação imediata, do início de sua vigência em diante, alterando para mais ou para menos o tempo ainda disponível para o ajuizamento da ação. Por exemplo: se a lei nova diminuir de 20 para 15 anos o prazo prescricional de determinada ação, seu titular não poderá se valer do prazo antigo depois do início de vigência da novel norma, nem deixar de computar o período já transcorrido.

No entanto, isto não permite que a lei nova possa desconsiderar o tempo que ainda havia por transcorrer. Conforme sustentamos no item 3.3.3, a lei nova não pode alterar a significação jurídica que o tempo tinha para o sistema anterior, sob pena de retroatividade - só admitida em casos especiais e de forma expressa. Por exemplo: se, quando do advento da lei nova, o titular tivesse deixado escoar 10 dos 20 anos previstos na lei anterior, teria havido o transcurso de metade do prazo para ajuizamento da ação. Apesar do advento de prazo novo, de 15 anos, esta relação, de 1/2, não pode ser afetada pelo advento da lei nova, de sorte que ainda restariam 7,5 anos para o exercício da pretensão, ou seja, quinze anos da nova norma multiplicados pela significação jurídica que os dez anos já transcorridos tinham perante os vinte anos da lei anterior $(15 \times 1 / 2)$.

A solução está em verificar, proporcionalmente, quanto o tempo já transcorrido significava para o sistema da lei revogada. Obtido um percentual, deverá ser calculado, de acordo com a lei nova, o prazo que ainda falta por cumprir. Regra de três da melhor técnica jurídica, conforme propõem os juristas Rubens Limongi França ${ }^{291}$ e Celso Antônio Bandeira de Mello $^{292}$, bem como o Projeto de Lei n ${ }^{\circ} 4.905 / 95$, que altera a Lei de Introdução ao Código Civil (item 2.5.3).

Contudo, apesar de a melhor sob o ponto de vista científico, a orientação não tem encontrado guarida na jurisprudência - observação que fazemos em tom de ressalva, crítica e alerta. Como se observa nos julgados abaixo, de lavra dos Ministros Teori Albino Zavascki e Francisco Falcão, do Superior Tribunal de Justiça, nossos Tribunais têm utilizado a seguinte fórmula: aplica-se o prazo da lei nova contado da data do início de sua vigência. Confira-se:

\footnotetext{
${ }^{291}$ FRANÇA, Rubens Limongi. Direito intertemporal brasileiro: doutrina da irretroatividade das leis e do direito adquirido, cit., p. 468.

${ }^{292}$ in MELLO, Celso Antonio Bandeira de. Direito adquirido proporcional, cit.
} 
“(...) A solução para o problema de direito intertemporal só pode ser uma: relativamente aos anteriores à nova lei, o prazo decadencial tem como termo inicial o da vigência da norma que o estabeleceu. Precedentes do STJ e do STF (...)" ${ }^{\$ 293}$.

“(...) No que concerne à regra de direito intertemporal aplicada à questão da prescrição, é imperioso salientar que, estabelecendo a nova lei um prazo prescricional menor, tal prazo começará a correr da data da nova lei, salvo se a prescrição que se iniciou sob a égide da lei anterior vier a se completar em menos tempo, conforme esta lei, que, em tal hipótese, continuará a reger a contagem do prazo prescricional (...)" ${ }^{\natural 294}$.

Se resguarda a segurança jurídica, tal regra descuida-se da isonomia, permitindo que a lei nova afete uma parte de maneira desigual em relação à outra. Por esta razão, deveria ser preferida a regra da proporcionalidade - a qual deverá ser conjugada com eventuais dispositivos transitórios, como é o caso do artigo 2.028 do Código Civil de 2002, de que se tratará adiante.

\subsubsection{Os prazos reduzidos pelo Código Civil de 2002 - o artigo 2.028}

Uma das mais significativas modificações do Código Civil de 2002 foi a redução de prazos diversos, de prescrição e decadência, amoldando-se a uma sociedade que não tolera inércia ou negligência. Por exemplo, o prazo geral de prescrição, nas ações pessoais, foi reduzido de 20 para 10 anos (artigo 205 do Código Civil de $2002^{295}$ ); o prazo da usucapião extraordinária de bem imóvel foi reduzido de 20 para 15 ou 10 anos (artigo 1.238 do Código Civil de $2002^{296}$ ); criou-se prazo especial, de 3 anos, para as ações de reparação civil, que antes se sujeitavam ao prazo geral das ações pessoais, de 20 anos (artigo 206, $\S 3^{\circ}$, inciso V,

\footnotetext{
${ }^{293}$ STJ, $1^{\text {a }}$ Turma, REsp n ${ }^{\text {o }}$ 1044550/PE, Rel. Min. Teori Albino Zavascki, j. 27.5.2008, v.u.

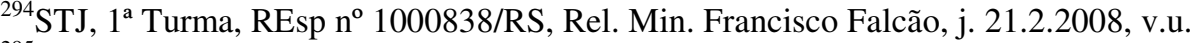

${ }^{295}$ Art. 205: "A prescrição ocorre em 10 (dez) anos, quando a lei não lhe haja fixado prazo menor". O dispositivo corresponde ao artigo 177 do Código Civil de 1916, que dispunha: "As ações pessoais prescrevem, ordinariamente, em 20 (vinte) anos, as reais em 10 (dez), entre presentes, e entre ausentes em 15 (quinze), contados da data em que poderiam ter sido propostas".

${ }^{296}$ Art. 1.238: "Aquele que, por 15 (quinze) anos, sem interrupção, nem oposição, possuir como seu um imóvel, adquire-lhe a propriedade, independentemente de título e boa-fé; podendo requerer ao juiz que assim o declare por sentença, a qual servirá de título para o registro no Cartório de Registro de Imóveis.

Parágrafo único. O prazo estabelecido neste artigo reduzir-se-á a 10 (dez) anos se o possuidor houver estabelecido no imóvel a sua moradia habitual, ou nele realizado obras ou serviços de caráter produtivo)". O dispositivo corresponde ao artigo 550 do Código Civil de 1916, que dispunha: "Aquele que, por 20 (vinte) anos, sem interrupção, nem oposição, possuir como seu um imóvel, adquirir-lhe-á o domínio, independentemente de título e boa-fé que, em tal caso, se presume, podendo requerer ao juiz que assim o declare por sentença, a qual lhe servirá de título para transcrição no Registro de Imóveis".
} 
do Código Civil de $2002^{297}$ ); a pretensão para enjeitar obra, em razão de vício coberto pela garantia legal da empreitada mista, passou a ter prazo decadencial de apenas 180 dias, contra os 20 anos da lei anterior (artigo 618, parágrafo único, do Código Civil de $2002^{298}$ ).

Procurando evitar conflitos de direito intertemporal, o Código Civil de 2002 previu regra transitória segundo a qual, em caso de redução, os novos prazos só serão aplicados quando não tiverem os da lei antiga transcorrido mais da metade. Dispõe o artigo 2.028:

“Art. 2.028. Serão os da lei anterior os prazos, quando reduzidos por este Código, e se, na data de sua entrada em vigor, já houver transcorrido mais da metade do tempo estabelecido na lei revogada".

Tal artigo merece duas ponderações. Primeira: como dispositivo transitório que é, $o$ artigo 2.028 só terá aplicação em caso de conflito (item 2.1), do qual só se poderá cogitar quando o Código Civil de 2002 houver reduzido um prazo do Código Civil de 1916. Por sua vez, só se poderá falar em redução quando o prazo posterior tiver a mesma natureza do anterior, pois senão se estará diante de direito novo, de aplicação imediata. Assim, o artigo 2.028 só deverá ser aplicado se houver choque prazo geral x prazo geral (artigo 205 do Código Civil de 2002 x artigo 177 do Código Civil de 1916) ou prazo especial x prazo especial (artigo

\footnotetext{
${ }^{297}$ Art. 206: "Prescreve:

(...)

$\S 3^{\circ}$.Em 3 (três) anos:

(...)

V.a pretensão de reparação civil".
}

${ }^{298}$ Art. 618: "Nos contratos de empreitada de edifícios ou outras construções consideráveis, o empreiteiro de materiais e execução responderá, durante o prazo irredutível de 5 (cinco anos), pela solidez e segurança do trabalho, assim em razão dos materiais, como do solo.

Parágrafo único.Decairá do direito assegurado neste artigo o dono da obra que não propuser a ação contra o empreiteiro, nos 180 (cento e oitenta) dias seguintes ao aparecimento do vício ou defeito".

O prazo de 180 dias, do artigo 618, parágrafo único, do Código Civil de 2002, refere-se apenas às pretensões constitutivas ou desconstitutivas, como por exemplo a rescisão de contrato. As pretensões condenatórias por vícios na obra, mesmo que abarcados na garantia legal da empreitada mista, sujeitam-se a prazo prescricional de 3 anos. É elucidativa a lição de José Fernando Simão, que merece ser transcrita e endossada: "Com relação ao prazo de 180 dias, entendemos que o 'direito assegurado' no parágrafo único e que está sujeito à decadência, não poderá dizer respeito à tutela condenatória de reparação de danos. Correta a doutrina que afirma que o prazo será aquele para a desconstituição do contrato (seja isto considerado redibição ou rescisão), bem como para o pleito de abatimento do preço (e o prazo também é decadencial em analogia à matéria dos vícios ocultos tratada no art. 445 do CC/2002). Entretanto, se a relação for de consumo, o prazo de decadência será de 90 dias, pois o bem imóvel é durável e seu início ocorrerá com o aparecimento do defeito (CDC, art. 26, II, § $\left.33^{\circ}\right)$.

Tratando-se de perdas e danos, o prazo para exercer a pretensão será de três anos para as relações civis e de cinco anos para as relações de consumo, prazos estes de natureza prescricional e que se iniciarão a partir do evento danoso" (in SIMÃO, José Fernando. Aspectos controvertidos da prescrição e decadência na teoria geral dos contratos e contratos em espécie. In: DELGADO, Mário Luiz; ALVES, Jones Figueiredo (Coords.). Questões controvertidas no novo Código Civil. São Paulo: Método, 2005. v. 4, p. 381). 
206 do Código Civil de 2002 x artigo 178 do Código Civil de 1916). Caso o Código Civil de 2002 tenha disciplinado como prazo especial matéria que antes era tratada na regra geral do Código Civil de 1916 (artigo 206 do Código Civil de 2002 x artigo 177 do Código Civil de 1916), e vice-versa, não terá havido redução mas sim inovação, que se impõe a todas as relações em curso, de forma imediata, independentemente do tempo já escoado sob a égide da lei anterior. Por exemplo: no Código Civil de 1916, o prazo para as ações de reparação civil era regulado pela regra geral, do artigo 177, por não haver, à época, prazo especial específico; por sua vez, o Código Civil de 2002 criou prazo especial específico para tais ações, no artigo 206, $\S 3^{\circ}$, inciso $\mathrm{V}$, constituindo inovação na ordem jurídica, que se aplica desde logo, por não conflitar com o sistema anterior. Daí por que o prazo de 3 anos para as ações de reparação civil, do artigo 206, § $3^{\circ}$, inciso V, do Código Civil de 2002, deverá ser aplicado sempre de forma imediata, em respeito ao artigo $6^{\circ}$, caput, da Lei de Introdução ao Código Civil, mesmo que antes de 11 de janeiro de 2003 já tenham fluído mais de 10 anos para a propositura da ação - só não podendo o intérprete permitir que, somado ao tempo já transcorrido, o prazo novo supere o da lei anterior, sob pena de se ferir a ratio essendi da novel codificação civil.

O raciocínio é do crédito do douto Desembargador Nestor Duarte, cuja lição transcrevemos e endossamos:

"Necessário, todavia, atentar para a circunstância de que redução do prazo só há entre prazos da mesma classe. (...)

\section{(...)}

O novo Código aboliu a divisão do prazo geral conforme se trate de ação pessoal ou real. Há um único prazo geral de dez (10) anos, estabelecido no artigo 205, e os prazos especiais, definidos no artigo 206.

Sujeita a ação ao prazo geral do artigo 177 do Código Civil de 1916, o novo prazo é o do artigo 205 do Código vigente. Desse modo, se ao entrar em vigor o novo Código encontrou prazo geral em curso, primeiramente deve-se verificar se o tempo já decorrido é superior à metade do tempo estabelecido na lei revogada. Se o for, o prazo da lei revogada prevalecerá. Do contrário, aplica-se o prazo da lei nova, porém, sem desprezar o tempo já escoado na vigência da lei antiga, ou seja, a prescrição consumar-se-á com o tempo faltante para atingir o prazo da lei nova.

A dificuldade irá surgir quando a lei nova estabelece prazo especial, para a hipótese antes sujeita ao prazo geral. Trata-se, especificamente, do disposto no artigo 206, $\S 3^{\circ}$, V, que estipula o prazo prescricional de três (3) anos para a pretensão de reparação civil. No Código anterior, essa hipótese era de prazo geral, estabelecido em vinte (20) anos pelo artigo 
177. Ora, se na lei antiga o prazo era geral e na lei nova o prazo é especial, não ocorre propriamente conflito de lei no tempo, pois os objetos não são os mesmos. A identidade dos objetos é essencial para a configuração do conflito, como se pode extrair da definição de direito adquirido exarada por Rubens Limongi França e acima transcrita. Não havendo essa identificação, trouxe o Código vigente direito novo, que se submete apenas à regra do efeito imediato. Em conseqüência, o prazo trienal só passou a fluir com a entrada em vigor do novo Código.

Bem verdade que esse entendimento poderia levar à conclusão absurda de se admitir um prazo superior ao da lei antiga, como na hipótese de já haver transcorrido dezoito (18) anos na vigência do Código de 1916 e, somando-se três (3) anos, segundo o Novo Código, ter-se-ia o prazo de vinte e um (21) anos. Para obviar tal incoerência, a aplicação do prazo de três (03) anos não pode implicar o prazo total de mais de vinte (20) anos a contar do termo inicial (art. $5^{\circ}$ da Lei de Introdução ao Código Civil). Em síntese, o prazo de três (03) anos será contado desde a entrada em vigor do Novo Código, extinguindo-se, porém, antecipadamente, se alcançar o limite vintenário previsto na lei anterior, ${ }^{, 299}$.

Entretanto, a ressalva: embora as regras transitórias só devam ser cogitadas em caso de intertemporalidade conflitual (item 2.1), os Tribunais têm utilizado o artigo 2.028 sem qualquer distinção. A observação é feita novamente em tom de crítica e alerta.

A segunda ponderação ao artigo 2.028 diz respeito ao cômputo dos prazos estatuídos pelo Código Civil de 2002. Conforme sustentamos no item anterior, a lei nova não pode desprezar a significação jurídica que o tempo já transcorrido possuía para o sistema anterior, razão pela qual o intérprete deverá aplicar regra de proporcionalidade para o cálculo do prazo restante - o que valerá seja o artigo 2.028 aplicável ao caso ou não.

Doutrina e jurisprudência, no entanto, firmaram pronto e sólido entendimento de que a contagem dos novos prazos deveria ser feita de maneira integral, a partir do dia do início da vigência do Código Civil de 2002. Tal orientação restou consolidada no Enunciado 50 do Conselho da Justiça Federal, aprovado na I Jornada de Direito Civil:

\footnotetext{
"Art. 2.028. A partir da vigência do novo Código Civil, o prazo prescricional das ações de reparação de danos que não houver atingido a metade do tempo previsto no Código Civil de 1916 fluirá por inteiro, nos termos da nova lei (art. 206)"
}

${ }^{299}$ DUARTE, Nestor. op. cit., p. 357-359. 
Repisamos: embora resguarde a segurança jurídica, tal regra descuida-se da isonomia, permitindo que a lei nova afete uma parte de maneira desigual em relação à outra. Por esta razão, deveria ser preferida a regra de proporcionalidade enunciada no item precedente, mesmo nos casos em que o artigo 2.028 tenha aplicação.

Por fim, vale mencionar que a suspensão, a interrupção e o prazo totalmente escoado não são atingidos pela lei nova, em respeito ao ato jurídico perfeito.

Os prazos de usucapião serão tratados no âmbito do Direito das Coisas (item 5.5.2).

\title{
5.1.5. A necessidade de duas testemunhas para se conferir qualidade de título executivo ao instrumento particular - artigo 221 do Código Civil de $2002 \times$ artigo 585, inciso II, do Código de Processo Civil
}

O Código Civil de 1916 previa que o instrumento particular prova os fatos jurídicos se assinado por duas testemunhas. Dispunha o seu artigo 135:

\begin{abstract}
"Art. 135. O instrumento particular, feito e assinado, ou somente assinado por quem esteja na disposição e administração livre de seus bens, sendo subscrito por 2 (duas) testemunhas, prova as obrigações convencionadas de qualquer valor. Mas os seus efeitos, bem como os da cessão, não se operam, a respeito de terceiros (art. 1.067), antes de transcrito no Registro Público".
\end{abstract}

Por sua vez, o Código Civil de 2002 veio dispor que o instrumento particular prova os fatos jurídicos independentemente da assinatura de duas testemunhas. Dispõe o artigo 221:

\footnotetext{
"Art. 221. O instrumento particular, feito e assinado, ou somente assinado por quem esteja na livre disposição e administração de seus bens, prova as obrigações convencionais de qualquer valor; mas os seus efeitos, bem como os da cessão, não se operam, a respeito de terceiros, antes de registrado no registro público".
}

Para alguns autores, a alteração teria implicado revogação tácita do artigo 585, inciso II, do Código de Processo Civil, segundo o qual constitui título executivo o documento particular assinado por duas testemunhas: 
“Art. 585. São títulos executivos extrajudiciais:

(...)

II- a escritura pública ou outro documento público assinado pelo devedor; o documento particular assinado pelo devedor e por duas testemunhas; o instrumento de transação referendado pelo Ministério Público, pela Defensoria Pública ou pelos advogados dos transatores".

Para Antonio Jeová Santos, por exemplo, o artigo 221 do Código Civil de 2002, teria revogado o artigo 585, inciso II, do Código de Processo Civil, por se tratar de norma posterior, que revoga a anterior. Confira-se:

“O art. 221 do CC/02 revogou, de forma tácita, o art. 585, II, do CPC, na parte que exige duas testemunhas para que o documento seja considerado título executivo, porque lex posterior derrogat priorem ou no vernáculo: 'lei posterior revoga a anterior'. Aos contratos celebrados na vigência do atual Código, não mais será necessária a presença de testemunhas para a existência do título executivo. Ao deixar de ter este requisito para a validade do contrato, não pode a regra processual subsistir, mantendo tal exigência para que o contrato seja tido como título executivo extrajudicial.

Contratos firmados depois da vigência do Código Civil de 2002 que não tenham testemunhas, quando descumpridos e se tiverem os demais requisitos para a execução, como a liquidez, certeza e exigibilidade, servirão como título executivo, abstraída a parte do art. 585, II, do CPC que mantinha a obrigatoriedade de que no documento constasse a assinatura de duas testemunhas, para que a parte pudesse lançar mão do processo de execução"300.

Com o devido respeito, o entendimento não nos parece acertado, pois os artigos 221 do Código Civil de 2002 e 585, inciso II, do Código de Processo Civil, cuidam de questões diferentes, não havendo conflito entre os dispositivos nem revogação de um pelo outro (item 2.1). Os artigos localizados no Livro III, Título V, do Código Civil de 2002, "da prova" entre os quais se encontra o artigo 221 -, tratam apenas dos meios de prova, os quais poderão ou não constituir título executivo, dependendo do que disponha o Código de Processo Civil; por outro lado, os artigos situados no Livro II, Capítulo III, Seção II, do Código de Processo Civil, "do título executivo" - e.g. o artigo 585, inciso II -, impõem condições para que certos documentos sejam considerados títulos executivos, os quais, além de

\footnotetext{
${ }^{300}$ in SANTOS, Antonio Jeová. Direito intertemporal e o novo Código Civil: aplicações da Lei 10.406/2002.
}

2. ed. rev. atual. e ampl. São Paulo: Ed. Revista dos Tribunais, 2004. p. 186. 
provar, possibilitam o ajuizamento de ação de execução. Caso não preencha os requisitos impostos pelo Código de Processo Civil, o documento não deixa de ser meio de prova, podendo instruir ações que não possuam natureza executiva.

Embora o artigo 221 do Código Civil de 2002 seja lei posterior, o artigo 585, inciso II, do Código de Processo Civil, é lei especial, cuja vigência não cessa pela superveniência da lei geral.

De mais a mais, o artigo 2.043 é claro ao dispor que os preceitos de natureza processual não foram revogados pelo Código Civil de 2002:

"Art. 2.043. Até que por outra forma se disciplinem, continuam em vigor as disposições de natureza processual, administrativa ou penal, constantes de leis cujos preceitos de natureza civil hajam sido incorporados a este Código".

Em comentário ao artigo 221 do Código Civil de 2002, o Desembargador Nestor Duarte observa que, também por conta do artigo 2.043, mantém-se a exigência de duas testemunhas para que o contrato seja considerado título executivo: "o Código de 2002 não mais exige a presença de duas testemunhas, como fazia o anterior, entretanto, o Código de Processo Civil, para emprestar força executiva ao instrumento, mantém a exigência (art. 2.043 do CC; art. 585, II, do CPC), ${ }^{, 301}$.

Daí concluirmos que o artigo 221 do Código Civil de 2002 não revogou o artigo 585, inciso II, do Código de Processo Civil, continuando necessárias duas testemunhas para que o instrumento particular possa instruir ação de execução.

\subsection{Direito das Obrigações}

O direito das obrigações é o ramo do direito civil que menos sofre alterações. Tal se dá, segundo Pablo Stolze Gagliano e Rodolfo Pamplona Filho, porque "o desenvolvimento desse instituto jurídico liga-se mais proximamente às relações econômicas, não sofrendo,

\footnotetext{
${ }^{301}$ in DUARTE, Nestor. Código Civil comentado: doutrina e jurisprudência. Coord. Cezar Peluso. Barueri: Manole, 2007. p. 149.
} 
normalmente, influências locais (...) ${ }^{\text {302 }}$. Conforme observa Giselda Maria Fernandes Novaes Hironaka, "a teoria geral das obrigações permanece estática, inerte, quase imutável apesar do aumento do comércio jurídico"303.

O Código Civil de 2002 não escapou a esta certa imutabilidade, operando apenas alterações pontuais no direito das obrigações. De acordo com a citada autora, a maioria delas teria tido a finalidade de acabar com discussões sobre o texto do Código Civil de 1916, sem alterar a estrutura do instituto. Cita como exemplos, dentre outros, o texto dado ao artigo 251, parágrafo único, explicitando que, em caso de urgência, o credor pode mandar desfazer o ato, nas obrigações de não fazer ${ }^{304}$; no artigo 290 , que trata da cessão de crédito, há a substituição da expressão "não vale" por "não tem eficácia", de melhor técnica ${ }^{305}$; o artigo 330 veio estabelecer a presunção de que o pagamento reiteradamente feito em outro local significa renúncia do credor a receber no local primitivamente estabelecido ${ }^{306}$. As alterações mais significativas teriam ocorrido com relação aos juros, à cláusula penal e ao instituto da assunção de dívida, este último só disciplinado com o Código Civil de 2002.

A nosso ver, essas alterações suscitam quatro indagações de direito intertemporal, que procuraremos responder nos itens seguintes: (1) qual o novo percentual dos juros de mora, quando não convencionados? (2) qual o atual limite para os juros convencionados? (3) como se dá a contagem dos juros de mora no Código Civil de 2002? e (4) qual lei se aplica à cláusula penal, especialmente no que toca à limitação da multa condominial a apenas $2 \%$ ?

\subsubsection{O percentual dos juros de mora legais no Código Civil de 2002 - SELIC x CTN}

Pelo Código Civil de 1916, os juros de mora ${ }^{307}$, quando não convencionados, eram de $6 \%$ ao ano. Dispunha o artigo 1.062:

\footnotetext{
${ }^{302}$ in GAGLIANO, Pablo Stolze; PAMPLONA FILHO, Rodolfo. Novo curso de direito civil: obrigações. 7. ed. rev., atual. e reform. São Paulo: Saraiva, 2006. v. 2, p. 2.

${ }^{303}$ in HIRONAKA, Giselda Maria Fernandes Novaes. Direito das obrigações. In: DELGADO, Mário Luiz; ALVES, Jones Figueiredo (Coords.). Questões controvertidas no novo Código Civil. São Paulo: Método, 2005. p. 20.

${ }^{304}$ Id. Ibid., p. 23.

${ }^{305}$ Id. Ibid., p. 24.

${ }^{306}$ Id. Ibid., p. 27.

${ }^{307} \mathrm{Na}$ lição de Sílvio de Salvo Venosa, "juros são a remuneração que o credor pode exigir do devedor por se privar de uma quantia em dinheiro" (VENOSA, Sílvio de Salvo. Direito civil: teoria geral das obrigações e teoria dos contratos. 2. ed. São Paulo: Atlas, 2002. v. 2, p. 157). Podem ser compensatórios, para remunerar o capital empregado (por exemplo, os juros convencionados em uma compra e venda a prazo), ou
} 
"Art. 1.062. A taxa dos juros moratórios, quando não convencionada (art. 1.262 ), será de $6 \%$ (seis por cento) ao ano".

Com o Código Civil de 2002, os juros de mora, quando não convencionados, passaram a ser "a taxa que estiver em vigor para a mora do pagamento de impostos devidos à Fazenda Nacional". Dispõe o artigo 406:

\begin{abstract}
"Art. 406. Quando os juros moratórios não forem convencionados, ou o forem sem taxa estipulada, ou quando provierem de determinação da lei, serão fixados segundo a taxa que estiver em vigor para a mora do pagamento de impostos devidos à Fazenda Nacional”.
\end{abstract}

Tal alteração impõe duas perguntas: (1) qual lei deverá ser aplicada às relações em curso? e (2) qual o percentual a que se refere o artigo 406 ao mencionar "a taxa que estiver que estiver em vigor para a mora do pagamento de impostos devidos à Fazenda Nacional”?

A resposta à primeira pergunta deflui da regra do efeito imediato: como os juros de mora legais decorrem diretamente da lei, o Código Civil de 2002 se aplica a todas as relações em curso, do início de sua vigência em diante. Ao contrário do que ocorre com os juros de mora convencionados, a taxa de juros legais não constitui direito adquirido, tendo em vista que não existe direito adquirido ao direito objetivo.

A jurisprudência não tem destoado quanto ao ponto. A esse respeito, é elucidativa a decisão do Ministro Castro Filho, do Superior Tribunal de Justiça, segundo a qual os juros de mora renovam-se mês a mês, e devem, portanto, sofrer a incidência do artigo 406 do Código Civil de 2002, do início de sua vigência em diante. Confira-se:

“(...) Logo, tendo a citação da recorrente se dado na vigência do Código Civil revogado, em princípio, os juros devem sujeitar-se à regra do artigo 1.062 do referido diploma. Todavia, com o advento do novo Código Civil, aquele dispositivo de lei deixou de existir, passando a matéria a ser disciplinada pelo artigo 406 da novel codificação. Diante disso, e também, principalmente, do fato de os juros moratórios renovarem-se mês-a-mês, já que prestação de trato sucessivo, tenho que, no caso concreto, devem ser regulados, até 11 de janeiro de 2003, data da entrada em vigor da Lei 10.406/02, pelo artigo 1.062 do Código de 1916, e, a partir de então, pelo artigo 406 do atual Código Civil. Qualquer outra

moratórios, quando se destinarem a indenizar o credor pelo atraso no pagamento de uma dívida. O valor destes pode ser estipulado pelas partes, dentro dos limites do Decreto $n^{\circ} 22.626 / 33$, ou decorrer diretamente da lei, quando não convencionados. 
solução que se pretendesse dar ao caso acarretaria a aplicação ultra-ativa do Código Civil revogado, ou então a retroatividade dos comandos do novo Código, o que seria inadmissível.

É de se ter presente que a taxa de juros moratórios, à luz do antigo e do novo diploma civil, quando não convencionada, é a legal. Se é a legal, é a da lei em vigor à época de sua incidência" ${ }^{308}$.

Quanto ao percentual imposto pelo artigo 406 do Código Civil de 2002, doutrina e jurisprudência divergem. Uma primeira corrente sustenta que o dispositivo se referiria à taxa referencial do Sistema Especial de Liquidação e de Custódia (“SELIC”), que a partir de 1995 passou a ser acrescida aos tributos devidos à Fazenda Nacional. Tal conclusão tem apoio no artigo 84, inciso I, da Lei $\mathrm{n}^{\circ} 8.981 / 95$, combinado com os artigos 13 , da Lei $\mathrm{n}^{\circ}$ 9.605/95, e 39, $\S 4^{\circ}$, da Lei ${ }^{\circ} 9.250 / 95$, adiante transcritos:

"Art. 84. Os tributos e contribuições sociais arrecadados pela Secretaria da Receita Federal, cujos fatos geradores vierem a ocorrer a partir de $1^{\circ}$ de janeiro de 1995, não pagos nos prazos previstos na legislação tributária serão acrescidos de:

I - juros de mora, equivalentes à taxa média mensal de captação do Tesouro Nacional relativa à Dívida Mobiliária Federal Interna”.

"Art. 13. A partir de $1^{\circ}$ de abril de 1995 , os juros de que tratam a alínea c do parágrafo único do art. 14 da Lei $n^{\circ} 8.847$, de 28 de janeiro de 1994, com a redação dada pelo art. $6^{\circ}$ da Lei $\mathrm{n}^{\circ} 8.850$, de 28 de janeiro de 1994, e pelo art. 90 da Lei $\mathrm{n}^{\circ}$ 8.981, de 1995, o art. 84, inciso I, e o art. 91, parágrafo único, alínea a.2, da Lei $\mathrm{n}^{\circ}$ 8.981, de 1995, serão equivalentes à taxa referencial do Sistema Especial de Liquidação e de Custódia SELIC para títulos federais, acumulada mensalmente".

“Art. 39. A compensação de que trata o art. 66 da Lei ${ }^{\circ}$ 8.383, de 30 de dezembro de 1991, com a redação dada pelo art. 58 da Lei n ${ }^{\circ} 9.069$, de 29 de junho de 1995, somente poderá ser efetuada com o recolhimento de importância correspondente a imposto, taxa, contribuição federal ou receitas patrimoniais de mesma espécie e destinação constitucional, apurado em períodos subseqüentes.

\section{(...)}

$\S 4^{\circ}$. A partir de $1^{\circ}$ de janeiro de 1996 , a compensação ou restituição será acrescida de juros equivalentes à taxa referencial do Sistema Especial de Liquidação e de Custódia - SELIC para títulos federais, acumulada mensalmente, calculados a partir da data do pagamento indevido ou a maior até o mês anterior ao da compensação ou restituição e de $1 \%$ relativamente ao mês em que estiver sendo efetuada".

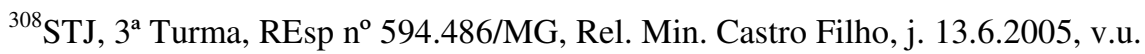


Abraçando essa conclusão, sustentam Mário Luiz Delgado e o Ministro Teori Albino Zavascki, ldo Superior Tribunal de Justiça:

"Na interpretação do art. 406, deve-se levar em conta a intenção do legislador, que procurou desestimular a rolagem temerária de dívidas, evitando que seja mais vantajoso adiar o pagamento de suas dívidas por anos a fio no Judiciário - com juros de mora de $0,5 \%$ ou $1 \%$ ao mês. Donde se conclui que o percentual que melhor se amolda à finalidade da norma é aquele correspondente à taxa SELIC, na medida em que submete as partes (credor e devedor) a um parâmetro sancionatório consideravelmente próximo ao praticado para remuneração do capital no mercado privado" ${ }^{\text {"309 }}$.

"A taxa à qual se refere o art. 406 do CC é a SELIC, tendo em vista o disposto nos arts. 13 da Lei 9.065/95, 84 da Lei 8.981/95, 39, $\S 4^{\circ}$, da Lei 9.250/95, $61, \S 3^{\circ}$, da Lei 9.430/96 e 30 da Lei 10.522/02"310.

Em que pese a tentação do argumento, a taxa SELIC não pode ser parâmetro para fixação dos juros de mora legais, nas relações privadas. Em primeiro lugar, deve-se atentar para a observação do Ministro Franciulli Netto, do Superior Tribunal de Justiça, de que a taxa SELIC é composta não só por juros mas também por correção monetária, por conter embutida "fator de neutralização da inflação"311. Logo, a SELIC não se presta apenas a indenizar a mora do pagamento de impostos devidos à Fazenda Nacional, como quer o artigo 406, não refletindo pois a ratio essendi do Código Civil de 2002.

Em segundo lugar, a adoção de uma taxa composta, contendo juros e atualização, poderia gerar enriquecimento ilícito do credor, com a aplicação simultânea de dois critérios de correção monetária. Nesse sentido, sustenta Hamid Charaf Bdine Jr:

“(...) A taxa Selic padece da ilegalidade por compreender, além de juros, componente de correção monetária, de modo que corrigir a dívida e acrescer a ela os juros correspondentes à taxa SELIC representará dupla correção, com enriquecimento ilícito do credor (...). Não bastaria utilizar a taxa Selic isoladamente, pois não seria possível que o devedor distinguisse entre a taxa de correção monetária e os juros nela compreendidos ficando impedido, por exemplo, de verificar se a atualização seguiu o índice oficial" ${ }^{\prime 312}$.

\footnotetext{
${ }^{309}$ in DELGADO, Mário Luiz. op. cit., p. 114. O argumento não se mostrou verdadeiro, pois hoje, quatro anos depois da edição da obra, a taxa SELIC é inferior a $1 \%$ ao mês.

${ }^{310}$ STJ, $1^{\text {a }}$ Turma, REsp no 932.329/RJ, Rel. Min. Teori Albino Zavascki, j. 15.5.2007, v.u.

${ }^{311}$ STJ, $2^{\text {a }}$ Turma, REsp no $215881 /$ PR, Rel. Franciulli Netto, j. 13.6.2000, v.u.

${ }^{312}$ in BDINE JR., Hamid Charaf. Código Civil comentado: doutrina e jurisprudência. Coord. Cezar Peluso. Barueri: Manole, 2007. p. 26. Logo que entrou em vigor o Código Civil de 2002, Judith Martin-Costa já sustentava que os juros moratórios não podem refletir mais que os juros reais, os quais, segundo explica, são aqueles deflacionados, ou seja, que não contêm nada além dos juros, como por exemplo a correção
} 
Além do mais, a adoção de uma taxa flutuante atentaria contra a segurança jurídica, impedindo que as partes conhecessem previamente os juros a que estarão sujeitas em caso de inadimplemento - questão esta a qual ganha relevância a se lembrar que os juros legais, do artigo 406, servem de parâmetro para a fixação dos juros convencionados, do que se tratará no item seguinte. Reforça a assertiva a afirmação de Rogério de Meneses Fialho Moreira:

"É certo que a matéria está longe de ser pacificada. Os sequazes da opinião de que os juros legais, atualmente, são aqueles calculados com base na taxa SELIC sustentam que não é necessário o prévio conhecimento dos juros e que, de acordo com o próprio Supremo Tribunal Federal, o art. 192, $\S 3^{\circ}$, da Constituição Federal não é autoaplicável.

Tais argumentos não podem prevalecer. Mesmo sendo possível a conclusão de contratos aleatórios, não é razoável que os juros moratórios, em todos os negócios jurídicos celebrados no país, fiquem à critério (sic) da discrição da autoridade monetária, somente sendo aferível a taxa aplicável no momento da execução. E digo todos os negócios porque, mesmo naqueles em que os juros forem convencionais, o seu limite máximo, por força da Lei da Usura, ainda em vigor, dependerá da fixação dos juros legais, já que os primeiros não podem exceder o dobro destes últimos" ${ }^{, 313}$.

Mostra-se pois ilegal a adoção da SELIC como parâmetro do artigo 406, do Código Civil de 2002, recomendando-se aí a adoção da taxa prevista na regra geral do artigo 161, $\S 1^{\circ}$, do Código Tributário Nacional, de $1 \%$ ao mês:

"Art. 161. O crédito não integralmente pago no vencimento é acrescido de juros de mora, seja qual for o motivo determinante da falta, sem prejuízo da imposição de penalidades cabíveis e da aplicação de quaisquer medidas de garantia previstas nesta Lei ou em lei tributária.

monetária. São suas palavras: “o art. 406 está conectado à idéia de ‘juros reais'. Assim, para o cálculo dos juros legais moratórios, deve ser utilizada taxa empregada para a cobrança dos juros de mora devidos à Fazenda Nacional desde que essa taxa seja adstrita aos juros reais. Portanto, o emprego de qualquer taxa que englobe mais do que juros reais, ou coisa diversa do que os juros reais, será inconstitucional, contrariando a eficácia inibitória do art. 192, § $3^{\circ}$ " (in MARTINS-COSTA, Judith. Os juros (moratórios) legais: para uma interpretação do art. 406 do Código Civil. Migalhas. Disponível em: $<$ http://www.migalhas.com.br/mostra_noticia_articuladas.aspx?cod=1426>. Acesso em: 26 maio 2008). Sustenta também Rogério de Meneses Fialho Moreira que a adoção de taxa composta contrariaria ratio do artigo 406 do Código Civil de 2002, o qual trata apenas de juros de mora legais, sem se referir à correção monetária. Confira-se: "Ora, o art. 406 do Código Civil determina que os juros moratórios legais 'serão fixados segundo a taxa que estiver em vigor para a mora do pagamento de impostos devidos à Fazenda Nacional'. Tratando o dispositivo especificamente de juros de mora, é evidente que a expressão 'taxa que estiver em vigor' diz respeito a juros moratórios, e não a qualquer taxa empregada pelo fisco federal para compensar a demora no recebimento dos seus créditos" (in MOREIRA, Rogério de Meneses Fialho. A nova disciplina dos juros de mora: aspectos polêmicos. In: DELGADO, Mário Luiz; ALVES, Jones Figueiredo (Coords.). Questões controvertidas no novo Código Civil. São Paulo: Método, 2003. p. 281).

${ }^{313}$ in MOREIRA, Rogério de Meneses Fialho, op. cit., p. 282. 
$\S 1^{\circ}$. Se a lei não dispuser de modo diverso, os juros de mora são calculados à taxa de $1 \%$ (um por cento) ao mês".

Esta a orientação do Conselho de Justiça Federal, ao justificar o enunciado n $^{\mathbf{0}} 20$ :

"Art. 406: a taxa de juros moratórios a que se refere o art. 406 é a do art. 161, § $1^{\circ}$, do Código Tributário Nacional, ou seja, $1 \%$ (um por cento) ao mês. A utilização da taxa SELIC como índice de apuração dos juros legais não é juridicamente segura, porque impede o prévio conhecimento dos juros; não é operacional, porque seu uso será inviável sempre que se calcularem somente juros ou somente correção monetária; é incompatível com a regra do art. 591 do novo Código Civil, que permite apenas a capitalização anual dos juros, e pode ser incompatível com o art. 192, $\S 3^{\circ}$, da Constituição $\mathrm{Federal}^{314}$, se resultarem juros reais superiores a $12 \%$ (doze por cento) ao ano".

O Superior Tribunal de Justiça, dividido, também tem decidido nesse sentido. A esse respeito, confira-se voto relatado pelo Ministro Humberto Gomes de Barros:

"1. Até a data da entrada em vigor do novo Código Civil, o juros moratórios são regulados pelo artigo 1.062 do Código Beviláqua. Depois daquela data, aplica-se a taxa prevista no artigo 406 do atual Código Civil, na razão de $1 \%$ ao mês.

2. A taxa SELIC tem aplicação específica a casos previstos em Lei, tais como restituição ou compensação de tributos federais. Não é a ela que se refere o Art. 406 do novo Código Civil, mas ao percentual previsto no Art. $161, \S 1^{\circ}$, do CTN. (...) ${ }^{, 315}$.

Conclui-se, assim, que os juros de mora legais serão de $0,5 \%$ ao mês até 11 de janeiro de 2003 e de $1 \%$ ao mês desta data em diante, em atenção à regra do efeito imediato e a uma interpretação combinada dos artigos 406, do Código Civil de 2002, e 161, § $1^{\text {o }}$, do Código Tributário Nacional.

\footnotetext{
${ }^{314}$ Artigo revogado pela Emenda Constitucional no 40/2003.

${ }^{315}$ STJ, $3^{\text {a }}$ Turma, Ag. Reg. no REsp no 727842/SP, Rel. Min. Humberto Gomes de Barros, j. 14.12.2007, v.u.
} 


\subsubsection{O novo limite para os juros convencionados - Código Civil de 2002 e Lei da} Usura

A Lei da Usura determina que o teto dos juros convencionados é o dobro da taxa legal. Dispõe o artigo $1^{\circ}$, caput, do Decreto n ${ }^{\circ} 22.626 / 33$ :

"Art. $1^{\circ} . E$ É vedado, e será punido nos termos desta lei, estipular em quaisquer contratos taxas de juros superiores ao dobro da taxa legal (Código Civil, art. 1062)"

Pelo Código Civil de 1916, artigo $1.062^{316}$, a taxa legal era de $6 \%$ ao ano (ou $0,5 \%$ ao mês), não se podendo, à época, estipular juros acima de $12 \%$ ao ano (ou $1 \%$ ao mês) vez que, conforme visto, a Lei da Usura só permite convencionar juros de até o dobro do limite da taxa legal. Contudo, com o Código Civil de 2002, artigo 406, a taxa legal passou a ser de $12 \%$ ao ano (ou $1 \%$ ao mês), alterando-se pois para $24 \%$ ao ano (ou $2 \%$ ao mês) o limite para os juros convencionados. Esta a nova taxa máxima para os juros convencionados.

Entretanto, nos contratos de mútuo feneratício as partes não poderão convencionar juros acima da taxa legal, de $12 \%$ ao ano (ou $1 \%$ ao mês). Diferentemente do Código Civil de 1916, cujo artigo 1.262 permitia fixar juros acima da taxa legal - até então de $6 \%$ ao ano (ou 0,5\% ao mês) ${ }^{317}$-, o Código Civil de 2002, no artigo 591, limitou os juros do mútuo ao teto da taxa legal - que agora é de $12 \%$ ao ano (ou $1 \%$ ao mês). Dispõe o artigo 591 do Código Civil de 2002:

“Art. 591. Destinando-se o mútuo a fins econômicos, presumem-se devidos juros, os quais, sob pena de redução, não poderão exceder a taxa a que se refere o art. 406, permitida a capitalização anual" ${ }^{\prime 318}$.

\footnotetext{
${ }^{316}$ Art. 1.062: “A taxa dos juros moratórios, quando não convencionada (art. 1.262), será de 6\% (seis por cento) ao ano",

${ }^{317}$ Art. 1.262: "É permitido, mas só por cláusula expressa, fixar juros ao empréstimo de dinheiro ou de outras coisas fungíveis.

Esses juros podem fixar-se abaixo ou acima da taxa legal (art. 1.062), com ou sem capitalização".

${ }^{318}$ Não se alegue que o artigo 591 tenha revogado a Lei da Usura, tendo em vista que este dispositivo se refere apenas ao mútuo feneratício, e não aos contratos ou aos juros em geral. Muitas são as hipóteses, além do mútuo, em que as partes podem convencionar juros compensatórios ou moratórios (por exemplo, compras e vendas a prazo, convenções de condomínio, transações etc.), casos em que não estarão adstritas ao limite imposto pelo artigo 591.
} 
Logo, tem-se o seguinte: a partir de 11 de janeiro de 2003, as partes poderão convencionar juros moratórios ou compensatórios de até $24 \%$ ao ano (ou $2 \%$ ao mês), desde que não estejam diante de contrato de mútuo. Caso sejam parte em contrato de mútuo, estarão limitadas à taxa de $12 \%$ ao ano (ou $1 \%$ ao mês $)^{319}$.

Importante ressaltar, no entanto, que os novos limites não se aplicam aos contratos firmados antes de 11 de janeiro de 2003. Primeiro porque o Código Civil de 2002 não possui efeito retroativo; segundo porque a taxa dos juros convencionados constitui direito adquirido, o qual não sofre o efeito imediato da nova lei. Caso um contrato anterior a 11 de janeiro de 2003 contenha estipulação fora dos limites legais, tal avença não se convalidará pelo advento do Código Civil de 2002.

\subsubsection{A contagem dos juros de mora no Código Civil de 2002 - as inovações constantes dos artigos 398 e 405}

Os juros moratórios destinam-se a indenizar o credor pelo inadimplemento de uma obrigação, razão pela qual são contados, em regra, a partir do momento em que o devedor é constituído em mora.

No Código Civil de 1916, eram basicamente as seguintes, em número de cinco, as regras referentes à contagem da mora: nas obrigações líquidas a termo, o devedor se constituía em mora com o não-adimplemento no prazo assinado (artigo 960, primeira parte, do Código Civil de $1916^{320}$ ); nas obrigações ilíquidas, com ou sem termo, o devedor era constituído em mora com a citação (artigo 1.536, § 2 $2^{\circ}$, do Código Civil de 1916 ${ }^{321}$ ); nas obrigações sem termo assinado, o devedor era constituído em mora desde a interpelação, notificação ou protesto (artigo 960, segunda parte, do Código Civil de $1916^{322}$ ); nas obrigações negativas, o devedor ficava constituído em mora quando praticasse o ato de que havia de se abster (artigo 961

\footnotetext{
${ }^{319}$ Tal entendimento não se aplica às Instituições Financeiras, as quais gozam da benesse de ter o limite de juros fixado por ato do Banco Central do Brasil.

${ }^{320}$ Art. 960, primeira parte: “O inadimplemento da obrigação, positiva e líquida, no seu termo constitui de pleno direito em mora o devedor".

${ }^{321}$ Art. 1.536: “( (...).

(...)

$\S 2^{\circ}$.Contam-se os juros da mora, nas obrigações ilíquidas, desde a citação inicial".

${ }^{322}$ Art. 960, segunda parte: "Não havendo prazo assinado, começa ela desde a interpelação, notificação ou protesto".
} 
do Código Civil de $1916^{323}$ ); nas obrigações decorrentes de delito, considerava-se o devedor em mora desde o momento em que o perpetrou (artigo 962 do Código Civil de $1916^{324}$ ).

Quanto a esta última regra, referente à mora nos atos ilícitos, o Superior Tribunal de Justiça fazia a seguinte distinção: fosse o ilícito extracontratual, aplicar-se-ia o artigo 962 do Código Civil de 1916, considerando-se o devedor em mora desde a prática do ato ilícito; por outro lado, nos casos de ilícito contratual, a mora deveria ser contada apenas a partir da citação, nos termos do artigo 1.536, § 2º do Código Civil de 1916. Daí o teor da Súmula $\mathrm{n}^{\mathrm{o}} 54$ do Superior Tribunal de Justiça: “os juros moratórios fluem a partir do evento danoso, em caso de responsabilidade extracontratual".

O Código Civil de 2002 repetiu ipsis literis três das regras do Código Civil de 1916: nas obrigações líquidas a termo, o devedor ainda é constituído em mora pelo mero nãoadimplemento no prazo (artigo 397, caput $^{325}$ ); nas obrigações sem termo assinado, a mora se constitui mediante interpelação judicial ou extrajudicial, como no diploma revogado (artigo 397, parágrafo único ${ }^{326}$ ); nas obrigações negativas, o devedor continua a ser havido em mora desde o dia em que praticou o ato de que havia de se abster - embora tal disposição agora conste do título referente ao inadimplemento, e não especificamente no capítulo relativo à mora (artigo 390) $)^{327}$.

Por outro lado, o Código Civil de 2002 operou as seguintes alterações no que toca ao momento da verificação da mora: não há dispositivo específico e expresso quanto à mora nas obrigações ilíquidas; no artigo que trata da mora nos atos ilícitos, a palavra "delito" foi substituída pela expressão "ato ilícito" (artigo $398^{328}$ ); no capítulo referente às perdas e danos, foi introduzido artigo dispondo que os juros de mora são contados a partir da citação inicial (artigo $405^{329}$ ).

\footnotetext{
${ }^{323}$ Art. 961: "Nas obrigações negativas, o devedor fica constituído em mora, desde o dia em que executar o ato de que se devia abster".

${ }^{324}$ Art. 962: "Nas obrigações provenientes de delito, considera-se o devedor em mora desde que o perpetrou".

${ }^{325}$ Art. 397: "O inadimplemento da obrigação, positiva e líquida, no seu termo, constitui de pleno direito em mora o devedor".

${ }^{326}$ Art. 397, parágrafo único: "Não havendo termo, a mora se constitui mediante interpelação judicial ou extrajudicial".

${ }^{327}$ Art. 390: "Nas obrigações negativas o devedor é havido por inadimplente desde o dia em que executou o ato de que se devia abster".

${ }^{328}$ Art. 398: "Nas obrigações provenientes de ato ilícito, considera-se o devedor em mora, desde que o praticou".

${ }^{329}$ Art. 405: "Contam-se os juros de mora desde a citação inicial".
} 
Tais alterações suscitam as seguintes questões: (1) o novel artigo 405 impõe que os juros moratórios sejam contados sempre a partir da citação, independentemente do momento em que o devedor é constituído em mora? e (2) a substituição da palavra "delito" pela expressão "ato ilícito" altera o entendimento segundo o qual os juros de mora só são contados da data do fato nos casos de responsabilidade extracontratual? Ou seja, a Súmula ${ }^{\circ} 54$ do STJ seria incompatível com o Código Civil de 2002?

Já há vozes proclamando que, com o artigo 405 do Código Civil de 2002, os juros de mora deveriam ser contados sempre da citação, independentemente do momento em que o devedor é constituído em mora. Nesse sentido, Rogério de Meneses Fialho Moreira:

“(...) não há dúvida de que o Código em vigor continua a fixar momentos distintos para se considerar em mora o devedor, em hipóteses várias, a exemplo das obrigações negativas, das decorrentes de ato ilícito, etc. Mas aquelas circunstâncias são irrelevantes para a fixação do termo inicial dos juros moratórios, que correrão sempre da CITAÇÃ̃O INICIAL.

\section{(...)}

(...) a fluência dos juros moratórios independe da data da constituição em mora. Diferentemente do sistema anterior, a simples ocorrência da mora não faz com que os juros moratori comecem a fluir. Isto porque o legislador de 2002 escolheu uma data única como termo inicial dos juros: A CITAÇÃO.

O art. 219 do Código de Processo Civil continua inalterado a respeito do tema de que trata: DA CONSTITUIÇÃO EM MORA, escolhendo a citação como critério supletivo, à falta de outro momento previsto em lei. Aquele dispositivo nada fala acerca de juros de mora.

Logo, atualmente o único dispositivo legal (de direito material ou processual) que trata especificamente de juros moratórios é o art. 405 do Código Civil de 2002, tendo escolhido critério único para a sua fluência: a citação inicial” ${ }^{, 330}$.

O entendimento data venia não deve ser seguido, pois desconsidera a finalidade dos juros de mora. Se os juros moratórios destinam-se a indenizar o credor pelo inadimplemento de uma obrigação, esta indenização deve guardar relação com o momento em que o devedor poderia ter cumprido a obrigação inadimplida - o qual se conta da mora. Entendimento diverso privilegiaria o devedor que se furta do cumprimento de suas obrigações, prolongando o prejuízo do credor por saber que só deverá juros depois de citado.

\footnotetext{
${ }^{330}$ in MOREIRA, Rogério de Meneses Fialho, op. cit., p. 272 e 274.
} 
O artigo 405 do Código Civil de 2002 só tem aplicação aos casos em que seja necessária interpelação e para os quais não haja regra expressa de constituição da mora, em respeito ao corolário de que dies interpellat pro homine. Nesse sentido é a lição de Renan Lotufo:

\begin{abstract}
"O que se há de entender é que o artigo fixa o termo inicial para o cômputo dos juros de mora às obrigações que dependem de interpelação para a constituição em mora, pois, evidentemente, inaplicável às obrigações decorrentes de ato ilícito (art. 398), como as hipóteses que tipificam a mora ex re, pela fixação prévia do termo, a par de a obrigação ser líquida e positiva (art. 397, caput).

A introdução desse dispositivo implicou a alteração de localização no sistema do Código, atendendo à melhor técnica" ${ }^{\text {"331 }}$.
\end{abstract}

Portanto, o artigo 405 do Código Civil de 2002 terá aplicação apenas às obrigações ilíquidas, não tendo havido alterações consideráveis entre este e o artigo 1.536, $\S 2^{\circ}$, do Código Civil de 1916.

Com relação à questão da substituição da palavra "delito" pela expressão "ato ilícito", no artigo 398 do Código Civil de 2002, entendemos ter havido alteração substancial: ao interpretar a palavra "delito", constante do artigo 962 do Código Civil de 1916, o Superior Tribunal de Justiça se reportava à idéia de ilícito absoluto, ou extracontratual. De acordo com esse entendimento, o ilícito relativo, ou contratual, não estaria contido no artigo 962 do Código Civil de 1916, devendo pois ser enquadrado no artigo 1.536, $\S 2^{\circ}$ do Código Civil de 1916, que tratava das obrigações ilíquidas em geral. Por isto é que apenas a mora decorrente de ilícito extracontratual era contada a partir do fato, nos termos do artigo 962 do Código Civil de 1916, enquanto a mora decorrente de ilícito contratual era contada da citação, nos termos do artigo $1.536, \S 2^{\circ}$, do Código Civil de $1916^{332}$.

Entretanto, ao mencionar "ato ilícito" ao invés de "delito", o Código Civil de 2002 veio abarcar tanto a hipótese de ilícito contratual como de ilícito extracontratual, não mais havendo espaço para distinções.

A esse respeito, confira-se entendimento de Renan Lotufo:

\footnotetext{
${ }^{331}$ in LOTUFO, Renan. Código Civil comentado: obrigações: parte Geral. São Paulo: Saraiva, 2003. p. 464.

${ }^{332}$ Conforme consta dos precedentes da Súmula no 54 do STJ (e.g. STJ, $2^{\text {a }}$ Seção, REsp no 11.624-0/SP, Rel. Min. Waldemar Zveiter, j. 27.11.1991, votação por maioria).
} 
“(...) a distinção entre dolo e culpa, para o Direito Civil, não tem a mesma função que para o Direito Penal. Ademais, o ato ilícito vem regulado pelo novo Código, art. 196, de sorte a não se poder excluir de sua tipificação a mora contratual" ${ }^{\prime 33}$.

No mesmo sentido decidiu o Desembargador Paulo Dias de Moura Ribeiro, do Tribunal de Justiça de São Paulo:

“(...) em se tratando de ilícito contratual, o valor da condenação reparatória, bem fixado, os juros da mora também deverão ser contados desde a data do evento danoso, na forma do art. 398, do CC/02.

Insisto na tese acima, ainda que não desconheça a posição do Col. STJ a respeito do tema que fixa o termo a quo para a contagem dos juros da mora nos casos de indenização por dano a pessoa em duas vertentes, distinguindo o ilícito: se a responsabilidade está fundada em contrato, os juros serão contados a partir da citação; se a responsabilidade é extracontratual, os juros fluem da data do fato, conforme enunciado na sua Súmula 54.

Mas, com o devido acatamento, não há razão jurídica, a partir da edição do Código Reale, para a distinção.

Isto porque (1) o posicionamento do Col. STJ a propósito dos juros de mora nos ilícitos contratuais se estribava no art. 1.536, § $2^{\circ}$, do CC/16, que nem sequer foi repetido no atual Código Civil; e (2) a regra do art. 398, do CC/02, de regência, está instalada no título 'Do Inadimplemento das Obrigações'.

\section{(...)}

Em arremate, se o art. $1.536, \S 2^{\circ}$, do $\mathrm{CC} / 16$ não tem mais equivalente no $\mathrm{CC} / 02$, não há mais razão jurídica para prevalecer a dicotomia feita pelo Col. STJ a respeito da contagem de juros da mora para as obrigações decorrentes de responsabilidade contratual ou extracontratual” ${ }^{\text {"34 }}$.

Nesse contexto, é de se concluir que, a partir do Código Civil de 2002, artigo 398, a mora nos atos ilícitos deve ser contada da data do fato, não importando tratar-se de ilícito contratual ou extracontratual. A Súmula ${ }^{\circ} 54$ do STJ é incompatível com o Código Civil

\footnotetext{
${ }^{333}$ LOTUFO, Renan. op. cit., p. 450.

${ }^{334} \mathrm{TJ} / \mathrm{SP}, 11^{\mathrm{a}}$ Câm. Dir. Priv., Ap. c/ rev. $\mathrm{n}^{\mathrm{o}}$ 7.220.054-5, Rel. Des. Gilberto Pinto dos Santos, vu, vencido o relator quanto ao início da contagem dos juros moratórios. Excerto tirado do voto proferido pelo Des. Paulo Dias de Moura Ribeiro.
} 
de 2002, não merecendo aplicação a partir de 11 de janeiro de 2003, mesmo para os ilícitos perpetrados em momento anterior a essa data ${ }^{335}$.

\subsubsection{A lei aplicável à cláusula penal - o valor da multa condominial estabelecido pelo artigo 1.336, $§ 1^{\circ}$, do Código Civil de 2002}

Antes do Código Civil de 2002, a convenção de condomínio podia estipular, para o caso de atraso no pagamento das contribuições, multa de até $20 \%$ sobre o valor do débito. A cobrança era autorizada pelo artigo $12, \S 3^{\circ}$, da Lei $n^{\circ} 4.591 / 64$, a dispor:

"Art. 12. Cada condômino concorrerá nas despesas do condomínio, recolhendo, nos prazos previstos na Convenção, a quota-parte que lhe couber em rateio.

\section{$(\ldots)$}

$\S 3^{\circ}$. O condômino que não pagar a sua contribuição no prazo fixado na Convenção fica sujeito ao juro moratório de $1 \%$ ao mês, e multa de até $20 \%$ sôbre o débito, que será atualizado, se o estipular a Convenção, com a aplicação dos índices de correção monetária levantados pelo Conselho Nacional de Economia, no caso da mora por período igual ou superior a seis meses".

Por sua vez, o Código Civil de 2002 determinou que a multa por inadimplemento não pode ultrapassar $2 \%$ do valor do débito. Dispõe o artigo $1.336, \S 1^{\circ}$ :

“Art. 1.336. São deveres do condômino:

$\S 1^{\circ}$. O condômino que não pagar a sua contribuição ficará sujeito aos juros moratórios convencionados ou, não sendo previstos, os de $1 \%$ (um por cento) ao mês e multa de até $2 \%$ (dois por cento) sobre o débito".

\footnotetext{
${ }^{335}$ O Código Civil de 2002 tem aplicação imediata, do início de sua vigência em diante, não permitindo ultratividade do Código Civil de 1916 senão quando houver direito adquirido, ato jurídico perfeito ou coisa julgada, o que não é o caso. Não se pode pretender a aplicação de uma Súmula contra lei posterior que lhe contrarie o texto. Não existe ultratividade de entendimento jurisprudencial.
} 
A alteração suscitou a questão: a limitação da multa, a 2\%, aplica-se a relações anteriores a 11 de janeiro de 2003? Em termos abstratos, a lei nova atinge convenção de condomínio e cláusula penal anteriores a seu advento?

Carlos Francesco Gabba responde negativamente à questão, sustentando que a aplicação da lei nova a convenção de condomínio e cláusula penal anteriores a seu advento representaria retroatividade injusta - a incidência da lei nova sobre ato jurídico perfeito, direito adquirido ou coisa julgada. Afirma que as partes, ao entabularem pena convencional, adquirem direito a receber uma determinada quantia em caso de inadimplemento, a qual não pode ser diminuída nem aumentada pela incidência da lei nova. Confira-se:

\begin{abstract}
"A origem do condomínio certamente deve ser regulada pela lei do tempo a que remonta" $" 336$.

"Constatado o dolo, ou determinado o grau de culpa do devedor no inadimplemento da obrigação, pode ocorrer que, a título de inadimplemento, ou de mora na execução da obrigação, ou de máexecução, deva-se prestar uma pena convencional. A estipulação e esta pena são regidas pela lei de seu tempo, sob o império da qual foram entabuladas.
\end{abstract}

\title{
$(\ldots)$
}

Em virtude do princípio geral, retro exposto, deve-se responder que a lei a ser aplicada é aquele vigente no dia em que a obrigação foi entabulada. $\mathrm{E}$, em verdade, não é possível que o interesse de uma das partes na execução da obrigação, assim como a natureza e as características desta, possam ser analisadas sem que se reporte ao entendimento que aquela parte possuía quando a obrigação havia se constituído, e, pois, à lei então vigente. Verdade é que aquilo que o credor mirava naquele dia era a execução leal e completa da obrigação, mas a lei contemplava para ela um outro desígnio também para o caso contrário, e o fazia adquirir, consciente ou inconscientemente, o direito de ser ressarcido de um certo modo e em uma certa medida se aquela perspectiva não fosse atingida. Tal direito, determinado de alguma forma por aquela lei, não poderia ser diminuído nem aumentado por lei posterior sem cometer uma injusta retroatividade, danosa ao credor ou ao devedor (...) ${ }^{\text {} 337}$.

\footnotetext{
${ }^{336}$ in GABBA, Carlos Francesco. op. cit., v. 3, p. 60. Tradução livre de: "L'origine della comunione deve certamente venir regolata secondo la legge vigente nel tempo a cui essa risale".

${ }^{337}$ GABBA, Carlos Francesco. op. cit., v. 4, p. 126. Tradução livre de: "Constatato il dolo, o determinato il grado della colpa del debitore nell'adempimento dell'obbligazione, può darsi che a titolo di inadempimento, o di mora nell'esecuzione dell'obbligo, o di mala esecuzione, debbasi prestare una pena convenzionale. La stipulazione e questa pena é retta in ogni tempo dalla legge, sotto il cui imperio venne posta in essere.

(...)

In virtù del principio generale, dinzi esposto, vuolsi rispondere, che la legge da apliccare à quella vigente nel giono in cui l'obbligazione venne posta in essere. E per verità non è possibile che l'interesse di una delle parti all'esecuzione dell'obbligo, del pari che l'indole o i caracteri dell'obbligo medesimo, si possano apprezzare se non se non col riportarsi all'intendimento che quella parte dovette avere allorchè l'obbligo
} 
De fato, embora o direito à indenização convencionada só vá ser percebido com o inadimplemento, a validade da estipulação que lhe dá origem deve ser protegida contra a incidência da lei nova, pois gera um direito de aquisição por elementos autônomos (item 3.3.2.1), o qual não pode ser atingido em suas partes perfeitas e individualizáveis - tal qual se dá, e.g., quanto à forma do testamento, a estipulação dos juros convencionados etc ${ }^{338}$.

Como afirma Denis Mazeaud, "a cláusula penal tem, por fim, por função, por causa, a execução da obrigação principal e original. Ela existe para garantir essa execução" ${ }^{339}$. Logo, se a lei nova atingisse a cláusula penal, ofenderia também a obrigação principal.

Daí por que o valor da cláusula penal anterior a 11 de janeiro de 2003, de até $20 \%$, não poderá sofrer a incidência do novel artigo 1.336, § $1^{\circ}$, do Código Civil de 2002, o qual só terá aplicabilidade depois do início de sua vigência ${ }^{340}$.

veniva costituito, e quindi ale leggi allora vigenti. Vero è che ciò a cui mirava il creditore in cui in quel giorno era l'esecuzione leale e completa dell'obbligazione, ma la legge contemplava per lui fin d'allora anche il caso contrario, e gli faceva acquistare, sciente o insciente, il diritto di essere risarcito in un dato modo e in una data misura, ove quella mira non si adempiesse. Tale diritto, determinato in qualunque modo da quella legge, non potrebbe essere scemato, nè aumentato da una legge posteriore, senza commettere un'ingiusta retroattività a danno del creditore o del debitore".

${ }^{338}$ No mesmo sentido: (1) Carlos Alberto Dabus Maluf (in MONTEIRO, Washington de Barros. Curso de direito civil: direito das obrigações. 37. ed. rev. e atual. por Carlos Alberto Dabus Maluf de acordo com o Novo Código Civil (Lei n. 10.406, de 10.1.2002). São Paulo: Saraiva, 2003. p. 229 e MALUF, Carlos Alberto Dabus. O condomínio edilício no novo Código Civil. Revista do Advogado, São Paulo, v. 22, n. 68, p. 61-69. dez. 2002; (2) Gil Ernesto Coelho (in COELHO, Gil Ernesto Gomes. A multa moratória da convenção de condomínio e o novo Código Civil: questão de direito intertemporal. In: CASCONI, Francisco Antonio; AMORIM, José Roberto Neves (Coords.). Condomínio edilício: aspectos relevantes aplicação do novo Código Civil. São Paulo: Método, 2005. p. 319-334); (3) Antonio Jeová Santos (in SANTOS, Antonio Jeová. op. cit., p. 112-113).

${ }^{339}$ in MAZEAUD, Denis. La notion de clause pénale. Paris: Librairie Générale de Droit et de Jurisprudence, 1992. Tradução livre de "la clause pánale a pour but, pour fonction, pour cause, l'exécution de l'obligation principale et originale. Elle est conclue pour garantir cette exécution".

${ }^{340}$ Em sentido contrário: (1) Mário Luiz Delgado, entendendo que a convenção de condomínio teria natureza estatutária, cujos efeitos se sujeitariam à lei posterior e não apenas à vontade das partes - as quais, ao aderir ao estatuto, já assentiriam com as modificações que leis futuras viessem a operar sobre a convenção (in DELGADO, Mário Luiz. op. cit., p. 99-102); (2) Luiz Antonio Rodrigues da Silva, sustentando que o limite de $2 \%$ se imporia às relações em curso por se tratar de norma cogente (in SILVA, Luiz Antonio Rodrigues. Pequena reflexão a respeito da multa de até $2 \%$ sobre a contribuição condominial em atraso. In: CASCONI, Francisco Antonio; AMORIM, José Roberto Neves (Coords.). Condomínio edilício: aspectos relevantes aplicação do novo Código Civil. São Paulo: Método, 2005. p. 317-318). 


\title{
5.3. Contratos
}

\subsubsection{A regra geral do Código Civil de 2002 - o artigo 2.035, caput}

O Código Civil de 2002 possui regra transitória para os atos e negócios jurídicos em geral. Prevê o artigo 2.035, caput:

\begin{abstract}
“Art. 2.035. A validade dos negócios e demais atos jurídicos, constituídos antes da entrada em vigor deste Código, obedece ao disposto nas leis anteriores, referidas no art. 2.045, mas os seus efeitos, produzidos após a vigência deste Código, aos preceitos dele se subordinam, salvo se houver sido prevista pelas partes determinada forma de execução".
\end{abstract}

Conjugando as regras do efeito imediato e da proteção ao direito adquirido, o artigo 2.035, caput, está a dispor que, como qualquer outra lei, o Código Civil de 2002 deverá atuar de forma imediata, do início de sua vigência em diante, preservando os fatos passados e incidindo sobre todas as relações futuras e em curso, desde que não ofenda direito adquirido, ato jurídico perfeito ou coisa julgada - donde (1) os atos e negócios jurídicos passados que tenham produzido todos os seus efeitos sob a égide da lei anterior não serão atingidos pelo Código Civil de 2002, em respeito ao ato jurídico perfeito; (2) pela mesma razão, a existência e a validade dos atos e negócios jurídicos constituídos antes de 11 de janeiro de 2003 não sofrerão os efeitos do Código Civil de 2002; (3) a contrario sensu, os atos e negócios jurídicos em formação, que não tenham sido concluídos antes de 11 de janeiro de 2003, deverão ser atingidos pelo Código Civil de 2002; (4) os atos e negócios jurídicos pendentes, que não tenham produzido todos os seus efeitos sob a égide da lei anterior, deverão ser cindidos em duas partes: (a) os efeitos anteriores a 11 de janeiro de 2003 não serão atingidos pelo Código Civil de 2003; (b) os efeitos posteriores a 11 de janeiro de 2003 deverão ser atingidos pelo Código Civil de 2002, salvo se constituírem direito adquirido. Por exemplo: os juros de mora legais percebidos depois de 11 de janeiro de 2003 serão os do Código Civil de 2002, pois os da lei antiga não constituem direito adquirido, ato jurídico perfeito ou coisa julgada (item 5.2.1); já os contratos de execução continuada ou diferida anteriores a 11 de janeiro de 2003 serão regidos pela lei vigente ao tempo de sua constituição, pois seus efeitos pendentes e posteriores constituem direito adquirido do titular da prestação (item 3.3.1). 
Tal dispositivo está em consonância com as tradições de nosso direito intertemporal, não prosperando as alegações de que sua parte final seria inconstitucional, como por exemplo o faz Antonio Jeová Santos:

"O legislador tentou resolver um problema e criou vários outros. A primeira parte do art. 2.035 contém o óbvio. Os atos jurídicos consolidados antes da entrada em vigor do Código Civil de 2002 estarão sob a égide da lei anterior. A segunda parte, que tentou resolver problema grave e sério de Direito intertemporal, não alcançou o fim desejado. Ao pretender que os efeitos dos negócios jurídicos ocorridos depois da vigência do novel Código, a ele se subordinem, vulnerou o legislador o art. 5. ${ }^{\circ}$ XXXVI, da Constituição da República.

\section{(...)}

Entretanto, a aplicação da lei nova aos facta pendentia, ou seja, aos efeitos das situações jurídicas constituídas no regime da lei antiga, configura, sem dúvida, retroatividade. Embora atenuada em relação à hipótese de aplicação da lei aos efeitos já consumados na vigência da lei anterior.

A doutrina cedo operou a clássica distinção entre retroatividade máxima, média e mínima.

\section{(...)}

A posição unânime e clara do Supremo Tribunal Federal e o siderúrgico entendimento de que é retroativa lei nova que pretende alcançar os efeitos futuros de negócios jurídicos conduzem o intérprete a não recear na asserção de que o art. 2.035 do $\mathrm{CC} / 2002$ padece do vício da inconstitucionalidade" ${ }^{341}$.

Data venia, há aí vários e sérios equívocos: (1) diferentemente do que afirma o autor, não é retroativa a lei que age no presente, do início de sua vigência em diante, sobre os fatos e relações em curso. Ao atuar sobre os fatos pendentes, mas sem se voltar sobre os passados, a lei age apenas com efeito imediato, que não só não é vedado como constitui a regra geral do sistema de direito intertemporal brasileiro (item 2.3.2); (2) mesmo que fosse retroativa, a segunda parte do artigo 2.035, caput, não seria necessariamente inconstitucional, tendo em vista que o direito intertemporal brasileiro não veda a retroatividade mas sim a ofensa a direitos adquiridos (item 2.3.1); (3) a teoria dos "níveis de retroatividade" não tem aplicação no direito intertemporal brasileiro, pois (a) ao criar os efeitos retroativo "médio" e "mínimo", acaba por sugerir uma vedação, inexistente, ao efeito imediato qualificado da lei nova, o qual, no

\footnotetext{
${ }^{341}$ in SANTOS, Antonio Jeová. op. cit., p. 74-84.
} 
direito intertemporal brasileiro, encontra limite apenas na proteção do direito adquirido, do ato jurídico perfeito e da coisa julgada (item 1.4.1); (b) a não-proteção da retroatividade média e mínima acaba por vulnerar a proteção do direito adquirido, que entre nós é assegurada constitucionalmente (item 1.4.1); (4) não é verdade que o Código Civil de 2002 não possa atingir efeitos presentes de fatos constituídos no passado - por exemplo, o Código Civil de 2002 regulará, do início de sua vigência em diante, a taxa de juros de mora legais, mesmo para os contratos anteriores a 11 de janeiro de 2003 (item 5.2.1); as faculdades conferidas pelo Código Civil de 2002 estendem-se aos cônjuges casados antes de 11 de janeiro de 2003 (itens 5.6.1 e 5.6.2); (5) os contratos de trato sucessivo não estão vulnerados pelo artigo 2.035, caput, segunda parte, pois o próprio dispositivo ressalva que o Código Civil de 2002 não terá aplicação "se houver sido prevista pelas partes determinada forma de execução" (item 2.3.3) ${ }^{342}$.

Portanto, será de acordo com esta regra, do artigo 2.035, caput, do Código Civil de 2002, que, em geral, deverão ser solucionados os conflitos de lei relacionados aos negócios jurídicos, observada a ressalva contida no parágrafo único desse dispositivo, de que se tratará a seguir.

\subsubsection{Uma falsa exceção - o artigo 2.035, parágrafo único}

Ao lado da regra geral enunciada no item anterior, o Código Civil de 2002 prevê exceção segundo a qual os negócios jurídicos não poderão continuar regidos por leis anteriores que contrariem preceitos de ordem pública, tais como a função social do contrato. Dispõe o artigo 2.035, parágrafo único:

\footnotetext{
“Art. 2.035. (...)

Parágrafo único. Nenhuma convenção prevalecerá se contrariar preceitos de ordem pública, tais como os estabelecidos por este Código para assegurar a função social da propriedade e dos contratos".
}

\footnotetext{
${ }^{342}$ Nosso entendimento se alinha, por exemplo, ao de Maria Helena Diniz, que, em trabalho de muito boa técnica, explica o alcance do artigo 2.035 do Código Civil de 2002 (in DINIZ, Maria Helena. O impacto do Art. 2.035 e Parágrafo Único nos contratos anteriores ao novo CC. In: DELGADO, Mário Luiz; ALVES, Jones Figueiredo (Coords.). Questões controvertidas no novo Código Civil. São Paulo: Método, 2005. v. 4, p. 471-480).
} 
Tal dispositivo tem suscitado polêmica, pois parte da doutrina vislumbrou, aí, uma recomendação legislativa para que se restabelecessem as discussões sobre direito adquirido e ordem pública. Como não poderia deixar de ser, essa leitura acabou por dividir a doutrina entre autores contrários e os favoráveis à constitucionalidade do artigo 2.035, parágrafo único, do Código Civil de 2002, uns entendendo que o direito adquirido prevalece sobre toda e qualquer norma infraconstitucional outros argumentando que este deve ceder à ordem pública.

Sustentando que o parágrafo único do artigo 2.035 seria inconstitucional, Antonio Jeová Santos afirma que o Supremo Tribunal Federal, ao julgar a ADIn 493-0/DF (item 4.2.1), teria fechado questão acerca da irretroatividade das normas de ordem pública:

“(...) o sistema de irretroatividade de leis no Brasil goza de hierarquia constitucional, não podendo o legislador, nem mesmo sob o fundamento de que está editando lei de ordem pública ou lei imperativa, dar-lhes caráter retroativo" 343 .

Mário Luiz Delgado, por outro lado, sustenta que, após o julgamento da ADIn 4930/DF, o Supremo Tribunal Federal teria proferido julgados pela prevalência da ordem pública:

"Ocorre que a posição trilhada pelo Pretório Excelso no julgamento da ADIn 493 não vem sendo uniforme, a se ver pela própria jurisprudência daquele sodalício, transcrita nesta obra. Em numerosos julgados o STF já decidiu pela aplicabilidade imediata das normas de ordem pública.

\section{(...)}

O que se vê, na prática, é que sempre que a jurisprudência assegura a irretroatividade da lei nova, é o valor de 'justiça' que ela pretende realizar.

\section{(...)}

Se, por um lado, exige a vida social que a fé na segurança e estabilidade das relações não seja ameaçada pelo receio de que uma lei posterior venha perturbar aquelas que validamente já se formaram, de outro, também é de se exigir a submissão do ordenamento aos interesses maiores da coletividade, de modo a se atingir o ideal de justiça e de utilidade, representação do bem comum. (...)

\section{(...)}

Se essas necessidades sociais, sentidas pela maioria dos que vivem em sociedade, determinaram a criação da norma, qualquer inovação de fundamento para sua invalidade deve ser interpretada levando-se em

\footnotetext{
${ }^{343}$ in SANTOS, Antonio Jeová. op. cit., p. 87.
} 
conta esses interesses maiores, que, em última análise, inspiram a própria Carta Magna” ${ }^{\text {344. }}$

Vale mencionar também o entendimento de Flávio Tartuce, para quem o artigo 2.035, parágrafo único, explicitaria uma antinomia real ${ }^{345}$, caracterizada pelo choque entre o direito adquirido e a função social da propriedade, ambos assegurados constitucionalmente. Para o autor, a constitucionalidade do artigo 2.035, parágrafo único, seria explicada pela ponderação de princípios, a recomendar, em seu entender, a prevalência da função social da propriedade e dos contratos sobre o direito adquirido. Esta a sua conclusão:

"Em outras palavras, não cabe a alegação de inconstitucionalidade da regra ora comentada, pela suposta infração à proteção ao direito adquirido, à coisa julgada e, sobretudo, ao ato jurídico perfeito, conforme previsto no Texto Maior (art. 5..$^{\circ}$ XXXVI) e no art. $6^{\circ}$ da Lei de Introdução ao Código Civil. Sob outro argumento, a justificativa para a retroatividade das normas de ordem pública nos casos em questão também encontra respaldo constitucional pela proteção da função social da propriedade lato sensu, que consta também no art. 5. ${ }^{\circ}$ da $\mathrm{CF} / 1988$, especificamente nos incisos XXII e XXIII. A partir da tese da ponderação de interesses, desenvolvida por Robert Alexy, pode-se afirmar que o próprio legislador fez a ponderação, pois entre proteger o direito adquirido em sentido amplo e a função da propriedade e dos contratos, preferiu os últimos conceitos"346.

A nosso ver, o artigo 2.035, parágrafo único, está a indicar que, contra certos preceitos de ordem pública, dificilmente terá havido aquisição de direitos, daí não havendo óbice a

\footnotetext{
${ }^{344}$ in DELGADO, Mário Luiz. op. cit., p. 93-95.

${ }^{345}$ Antinomia real é o conflito normativo que não pode ser solucionado por um critério pré-determinado de exclusão - diferentemente da antinomia aparente, a qual é resolvida pelos critérios hierárquico (a norma hierarquicamente superior prevalece sobre a inferior), da especialidade (a norma especial prevalece sobre a geral) e cronológico (a norma posterior prevalece sobre a anterior). Na lição de Tércio Sampaio Ferraz Jr., antinomia real é "a oposição que ocorre entre duas normas contraditórias (total ou parcialmente), emanadas de autoridades competentes num mesmo âmbito normativo, que coloca o sujeito numa posição insustentável pela ausência ou inconsistência de critérios aptos a permitir-lhe uma saída nos quadros de um ordenamento" (in FERRAZ JR., Tércio Sampaio. Antinomia. In: FRANÇA, Rubens Limongi (Org.). Enciclopédia Saraiva do Direito. São Paulo: Saraiva, 1977. v. 7, p. 14). Conforme ensina Maria Helena Diniz, a antinomia real deve ser resolvida por critérios de preenchimento de lacunas: "Ter-se-á, então, lacuna de conflito ou antinomia real quando as normas conflitantes se excluírem reciprocamente, por ser impossível deslocar uma como a mais forte, por não haver uma regra que permita decidir entre elas, obrigando o aplicador a utilizar os critérios de preenchimento de lacunas (LICC, arts. $4 .^{\circ}$ e 5. ${ }^{\circ}$ ). Como se vê, o reconhecimento de uma antinomia real não exclui a possibilidade de uma solução efetiva, pela aplicação de uma nova norma, que escolha uma das normas conflitantes, ou pelo emprego da interpretação eqüitativa, que recorra ao costume, aos princípios gerais de direito etc. (...)”. (in DINIZ, Maria Helena. Norma constitucional e seus efeitos. 2. ed. atuali. São Paulo: Saraiva. 1992. p. 114).

${ }^{346}$ TARTUCE, Flávio. op. cit., p. 401.
} 
que se aplique, de forma imediata, o Código Civil de 2002. Conforme expusemos no item 4.2.4, algumas leis de ordem pública - e este é o caso, e.g., dos artigos 421 e 422 do Código Civil de 2002 - apenas explicitam princípios que já estavam presentes no sistema jurídico, os quais impediam a aquisição do direito mesmo à míngua de lei em contrário.

Se, por exemplo, o negócio jurídico contrariar a função social do contrato, a parte a quem aproveita não poderá invocar direito adquirido, porque tal ato já poderia ser considerado um não-direito antes do artigo 421 do Código Civil de 2002. O ato contrário à função social tem apenas aparência de direito, não merecendo a mesma proteção conferida ao direito efetivamente adquirido. O Juiz não pode permitir que o direito intertemporal seja utilizado para agasalhar atos imperfeitos e direitos aparentes, blindando atos jurídicos nulos que não têm e não devem receber proteção contra o advento de lei nova que os expressamente proíba.

Não se trata da dicotomia direito adquirido versus ordem pública ou de uma ponderação posterior à formação do direito, o que refutamos (itens 4.2.2 e 4.2.3). Ao contrário, cuidase de uma ponderação na origem (item 4.2.4), que impõe ao Juiz investigar se o direito realmente havia se formado sob a égide da lei anterior ou se, mesmo antes da lei nova, o sistema jurídico já albergava princípios que impediam a aquisição. Voltando-se ao exemplo, o negócio contrário à função social é um ato nulo desde sempre, razão pela qual o artigo 421 do Código Civil de 2002 deverá ter aplicação imediata independentemente de sua natureza.

Esta a leitura que deverá receber o artigo 2.035, parágrafo único, do Código Civil de 2002, conforme já o sugeria Maria Helena Diniz:

"O parágrafo único do art. 2.035, sub examine, veio tão-somente reconhecer os já consagrados princípios da função social da propriedade e dos contratos como preceitos de ordem pública inderrogáveis pela vontade dos contratantes. A idéia de função social do contrato não é uma novidade do art. 421 do novel CC, que apenas o positivou expressamente, pois há muito tempo tem existência no ordenamento jurídico (...). $\mathrm{O}$ interesse social, baseado em norma de ordem pública e na justiça social que informam a função social do contrato, não acatado pelos contratantes, pode conduzir que a avença (por exemplo, a atinente a certa forma de execução) seja anulada 'retroativamente', pouco importando se celebrada anteriormente à entrada em vigor ao novo Estatuto Civil. Se o princípio da função social do contrato e o da propriedade são limites à norma de ordem pública e ao contrato, sempre serão aplicados pelos juízes e tribunais, sem que isso seja uma real aceitação da retroatividade da lei nova. Se aqueles princípios sempre existiram no ordenamento jurídico, qualquer cláusula contratual, anterior ou posterior ao Código Civil de 2002, passará pelo 
crivo do Judiciário, que lhe dará o tratamento a que fará jus, aplicando, inclusive, se for o caso, o parágrafo único do art. $2.035^{, 347}$.

Tal interpretação evita soluções agudas, permitindo concluir que o artigo 2.035, parágrafo único, não desconsidera o direito adquirido, depois de formado, mas apenas indica que certos atos não geram direito adquirido, recebendo a incidência imediata do Código Civil de 2002 independentemente de sua natureza.

\title{
5.3.3. Aplicabilidade da teoria da imprevisão a contratos e prestações anteriores ao
} Código Civil de 2002 - artigos 478 a 480

No sistema do Código Civil de 1916, a teoria da imprevisão não era prevista de forma expressa ${ }^{348}$, o que só veio a ocorrer com os artigos 478 a 480 do Código Civil de $2002^{349}$ :

\begin{abstract}
"Art. 478. Nos contratos de execução continuada ou diferida, se a prestação de uma das partes se tornar excessivamente onerosa, com extrema vantagem para a outra, em virtude de acontecimentos extraordinários e imprevisíveis, poderá o devedor pedir a resolução do contrato. Os efeitos da sentença que a decretar retroagirão à data da citação".

"Art. 479. A resolução poderá ser evitada, oferecendo-se o réu a modificar eqüitativamente as condições do contrato".

"Art. 480. Se no contrato as obrigações couberem a apenas uma das partes, poderá ela pleitear que a sua prestação seja reduzida, ou alterado o modo de executá-la, a fim de evitar a onerosidade excessiva."
\end{abstract}

Contudo, a nosso ver a teoria da imprevisão poderia ser aplicada a contratos e prestações anteriores a 11 de janeiro de 2003, pois os princípios que a fundamentam já estavam presentes no sistema jurídico antes do Código Civil de 2002, não dependendo de disposição de lei para encontrar concreção ${ }^{350}$. Conforme decidiu o Ministro Eduardo

\footnotetext{
${ }^{347}$ in DINIZ, Maria Helena. O impacto do Art. 2.035 e Parágrafo Único nos contratos anteriores ao novo CC, cit., p. 478.

${ }^{348}$ Embora alguns dispositivos já contivessem a idéia central do instituto, e.g., artigos 954 e 1.131 do Código Civil de $1916,6^{\circ}$ da Lei ${ }^{\circ} 8.078 / 90$ e 19 da Lei no $8.275 / 91$.

${ }^{349}$ Outros dispositivos do Código Civil de 2002 albergam o instituto, e.g. o artigo 620.

${ }^{350}$ Como afirma Arnaldo Rizzardo, a teoria está calcada no "princípio que admite a revisão ou a rescisão do contrato em certas circunstâncias especiais (...) que tornam a prestação de uma das partes sumamente onerosa" (in RIZZARDO, Arnaldo. Contratos. 3. ed. Rio de Janeiro: Forense, 2004. p. 137).
} 
Ribeiro, do Superior Tribunal de Justiça, a teoria da imprevisão poderia ser aplicada mesmo à míngua de texto expresso, por uma questão de eqüidade:

"TEORIA DA IMPREVISÃO. APLICABILIDADE, MESMO À MÍNGUA DE TEXTO EXPRESSO, POSTO QUE EXIGÊNCIA DA EQÜIDADE. NECESSIDADE, ENTRETANTO, DE QUE SE APRESENTEM TODOS SEUS PRESSUPOSTOS (...) ${ }^{, 351}$.

Nesse contexto, desde que presentes os pressupostos da teoria da imprevisão, o Juiz poderá resolver ou alterar contratos e prestações anteriores a 11 de janeiro de 2003, de forma a restabelecer equilíbrio e justiça buscados pelo sistema mesmo antes dos artigos 478 e seguintes do Código Civil de 2002.

\subsubsection{A possibilidade de o fiador exonerar-se por mera notificação, mesmo nos casos} de contrato anterior ao Código Civil de 2002 - os artigos 835 e 2.036

O Código Civil de 1916 dispunha que, houvesse subscrito fiança sem limitação de tempo, o fiador poderia exonerar-se somente mediante distrato ou por sentença. Dispunha o artigo 1.500:

\footnotetext{
"Art. 1.500. O fiador poderá exonerar-se da fiança que tiver assinado sem limitação de tempo, sempre que lhe convier, ficando, porém, obrigado por todos os efeitos da fiança, anteriores ao ato amigável, ou à sentença que o exonerar".
}

Por sua vez, o Código Civil de 2002 veio dispor que, nos casos de fiança sem limitação de tempo, o fiador poderá exonerar-se da obrigação por mera notificação extrajudicial, depois da qual se responsabilizará por mais sessenta dias. Dispõe o artigo 835:

“Art. 835. O fiador poderá exonerar-se da fiança que tiver assinado sem limitação de tempo, sempre que lhe convier, ficando obrigado por todos os efeitos da fiança, durante 60 (sessenta) dias após a notificação do credor".

\footnotetext{
${ }^{351}$ STJ, $3^{\text {a }}$ Turma, REsp n ${ }^{\text {o } 5723 / M G, ~ R e l . ~ M i n . ~ E d u a r d o ~ R i b e i r o, ~ j . ~ 25.6 .1991, ~ v . u . ~}$
} 
Diante de tal alteração, a pergunta: caso tenha assumido a obrigação antes de 11 de janeiro de 2003, o fiador poderá exonerar-se da fiança por mera notificação, nos termos do artigo 835 do Código Civil de 2002, ou deverá fazê-lo de forma amigável ou por sentença, de acordo com o artigo 1.500 do Código Civil de 1916 ?

A doutrina tem afirmado que, se a fiança for anterior ao Código Civil de 2002, o fiador só se poderia exonerar de forma amigável ou por sentença, de acordo com o artigo 1.500 do Código Civil de 1916. Assentada nos ensinamentos de Wilson de Souza Campos Batalha, tem-se sustentado que, por se tratar de contrato, a fiança deveria ser regulada pela lei vigente ao tempo de sua subscrição, inclusive quanto às formas de exoneração do fiador. Afirmava aquele autor: "Disciplina-se a fiança pela lei vigente ao tempo em que foi prestada e não pela lei em vigor à época da celebração do contrato principal. É a lei do tempo em que a fiança foi prestada que dirá (...) as hipóteses de extinção da fiança" ${ }^{352}$.

Esse não parece ser o entendimento correto. A lei nova só não deve ter aplicação imediata se encontrar óbice no direito adquirido, no ato jurídico perfeito ou na coisa julgada, o que não é o caso. Assim como o artigo 1.500 do Código Civil de 1916, o artigo 835 do Código Civil de 2002 dispõe sobre mera faculdade jurídica, a qual deve ser analisada sob a ótica da lei nova, mesmo que atinja relações em curso. Conforme afirmado no item 3.5.2, as faculdades jurídicas não constituem direito adquirido, tendo em vista que não existe direito adquirido ao direito objetivo. Por esta razão, o artigo 835 deve ter aplicação imediata, inclusive às fianças subscritas antes de 11 de janeiro de 2003.

Essa conclusão vale também para os contratos de locação, embora o artigo 39 da Lei $n^{\circ} 8.245 / 91$ disponha que, salvo disposição contratual em contrário, a obrigação do fiador se estende até a devolução do imóvel:

"Art. 39. Salvo disposição contratual em contrário, qualquer das garantias da locação se estende até a efetiva devolução do imóvel".

\footnotetext{
${ }^{352}$ in BATALHA, Wilson de Souza Campos. Direito intertemporal, cit., p. 393-394. Mário Luiz Delgado parece seguir a mesma orientação, mas com a ressalva de que, se o contrato principal houver sido prorrogado depois de 11 de janeiro de 2003, o fiador poderá se utilizar da faculdade conferida pelo artigo 835 do Código Civil de 2002 (in DELGADO, Mário Luiz. op. cit., p. 106-110). Já Antonio Jeová Santos afirma que se aplicaria à fiança a lei do contrato principal, acatada a ressalva feita por Mário Luiz Delgado. (in SANTOS, Antonio Jeová. op. cit., p. 179).
} 
Por se tratar de lei especial, tal dispositivo não foi revogado pelo Código Civil de 2002, mesmo porque o artigo 2.036 trouxe disposição expressa nesse sentido:

"Art. 2.036. A locação de prédio urbano, que esteja sujeita à lei especial, por esta continua sendo regida".

Note-se não haver contradição entre o artigo 835 do Código Civil de 2002, a permitir a exoneração do fiador por mera notificação extrajudicial, e o artigo 39 da Lei n $^{\circ}$ 8.245/91, o qual determina que a obrigação daquele se estende até a entrega das chaves. Conforme observa o Desembargador Cláudio Antônio Soares Levada, esta obrigação existirá até o fiador se exonerar, o que deverá ser feito na forma do artigo 835 do Código Civil de 2002. Segundo o autor, o artigo 835 do Código Civil de 2002 abre uma exceção ao artigo 39 da Lei $\mathrm{n}^{\circ} 8.245 / 91$, não havendo pois antinomia entre os dispositivos:

\begin{abstract}
"Note-se não haver colisão ou antinomia entre a regra do art. 835 do CC e o art. 39 da Lei do Inquilinato. Esta diz apenas que, salvo disposição contrária no contrato, as garantias da locação estendem-se até efetiva devolução do imóvel - e se estendem, realmente; já a regra do art. 835 do $\mathrm{CC}$ permite ao fiador exonerar-se da garantia prestada antes disso, faculdade que, não utilizada, fará com que se aplique a norma da lei inquilinária (...).

O que o art. 835 do CC fez (e, nesse ponto, o art. 1.500 do CC de 1916 já fazia), foi, apenas, inserir outra exceção ao art. 39 da Lei 8.245/91. Além da possibilidade de previsão contratual, também a previsão legal de exoneração da garantia antes da devolução do imóvel locado. Coexistem as normas, consequientemente, para situações fáticas distintas" ${ }^{353}$.
\end{abstract}

Por isso, o artigo 2.036 não impede a aplicação do novel 835 a fiança prestada em contrato de locação, pois, neste ponto, não há conflito entre o Código Civil de 2002 e a Lei $n^{\circ} 8.245 / 91$. Daí por que, também neste caso, de fiança em contrato de locação, o artigo 835 terá aplicação imediata, atingindo as relações iniciadas antes de 11 de janeiro de 2003.

\footnotetext{
${ }^{353}$ LEVADA, Cláudio Antônio Soares. Fiança locatícia: a responsabilização do garante até entrega das chaves e a faculdade de exoneração do artigo 835 do Código Civil. In: CASCONI, Francisco Antonio; AMORIM, José Roberto Neves (Coords.). Locações: aspectos relevantes - aplicação do novo Código Civil. São Paulo: Método, 2004. p. 61.
} 


\subsection{Responsabilidade Civil}

Em geral, o dever de indenizar surge com a prática de ato ilícito do qual decorra dano (artigo 927, caput, do Código Civil de 2002). Portanto, para que haja responsabilidade civil é necessária a conjunção destes dois elementos, ato ilícito e dano. Afirma Rui Stoco que "sem o binômio ato ilícito + dano não nasce a obrigação de indenizar" 354 .

O ato ilícito, por sua vez, caracteriza-se, em regra, pela violação de um dever jurídico imposto pela lei, com ou sem culpa do agente, podendo-se então enunciar que nas questões de responsabilidade civil se aplica a lei vigente ao tempo da prática do ilícito, pois não poderia a lei nova proibir ato já praticado, sob pena de ofensa ao princípio da legalidade (artigo $5^{\circ}$, inciso II, da Constituição Federal).

Se alterar as características de um ato ilícito (por exemplo, prescrevendo ou deixando de exigir culpa para sua caracterização), a lei nova só deverá ser aplicada aos fatos ocorridos depois do início de sua vigência, não importando o momento da caracterização do dano ou do julgamento da ação indenizatória. Afirma Wilson de Souza Campos Batalha: "as obrigações decorrentes de atos ilícitos regulam-se pela lei vigente ao tempo em que tais atos foram praticados, pouco importando a data da verificação do dano. (...) ${ }^{\text {’355. }}$

Contudo, mister uma ponderação a essa regra: novamente aqui, é necessário recordar que o ato ilícito nem sempre decorre de ofensa à lei. Conforme pontifica o Desembargador Cláudio Antônio Soares Levada,

"a lei não esgota o direito, nem o legal necessariamente confunde-se com o ilícito, que pode surgir da infração de conceitos determinados pela função, como o abuso, ou de lesão a cláusulas gerais, como a da boa-fé objetiva, ou da violação a princípios gerais do direito, como o que proíbe aproveitarse da própria torpeza" ${ }^{, 356}$.

Poderá ocorrer hipótese em que, por afrontar o sistema jurídico, um determinado ato já fosse considerado ilícito mesmo antes de lei a respeito, caso em que a norma, apesar de posterior, deverá ser aplicada ao fato ocorrido no passado. É o caso, por exemplo, do artigo

\footnotetext{
${ }^{354}$ STOCO, Rui. Tratado de responsabilidade civil. 6. ed. rev. atual. e ampl. São Paulo: Ed. Revista dos Tribunais, 2004. p. 124.

${ }^{355}$ in BATALHA, Wilson de Souza Campos. Direito intertemporal, cit., p. 337.

${ }^{356}$ LEVADA, Cláudio Antônio Soares. O abuso e o novo direito civil brasileiro, cit., p. 46-47.
} 
187 do Código Civil de 2002, o qual poderá ser aplicado retroativamente porque apenas enunciou algo que o sistema jurídico já prescrevia, que "também comete ato ilícito o titular de um direito que, ao exercê-lo, excede manifestamente os limites impostos pelo seu fim econômico ou social, pela boa-fé ou pelos bons costumes".

\subsection{Direito das Coisas}

Conforme ensina Carlos Roberto Gonçalves, "o direito real concede ao titular um gozo permanente porque tende à perpetuidade" ${ }^{, 357}$. Por essa razão, as questões intertemporais relacionadas aos efeitos dos direitos reais comportam-se, em geral, como as instituições jurídicas, não respeitando direitos adquiridos (item 3.5.3).

A conclusão tem respaldo na lição de Carlos Francesco Gabba:

"Todas as leis que introduzem novas figuras jurídicas objetivam o surgimento de novos direitos a partir de certos fatos (...). Conseqüentemente, se pode bem dizer que, em geral, as leis que introduzem novos direitos reais possuem aplicação imediata. (...) Este [o direito real] surge no mesmo dia em que há a atuação da lei sobre um fato permanente já verificado, e subsiste enquanto durar este fato",358.

Também já afirmava Wilson de Souza Campos Batalha:

“(...) Os direitos reais, caracterizados por sua permanência, estão sujeitos à lei nova no que tange à sua supressão ou a modificação do respectivo conteúdo e efeito (...). É certo que, ao suprimir ou restringir direitos dessa espécie, deve o legislador conferir indenização aos seus titulares, mas este é um problema de política legislativa, quando não de natureza constitucional, como ocorre entre nós, que nada tem a ver com o problema do conflito de leis no tempo, campo próprio da disciplina que ora nos preocupa" ${ }^{359}$.

\footnotetext{
${ }^{357}$ in GONÇALVES, Carlos Roberto. Direito civil brasileiro: direito das coisas. São Paulo: Saraiva, 2006. v. 5, p. 12.

${ }^{358}$ GABBA, Carlos Francesco. op. cit., v. 3, p. 17. Tradução livre de: "Tutte quante le leggi che introducono nuove figure di diritti, hanno per iscopo il far sorgere nuovi diritti da certi fatti (...). Conseguentemente si può ben dire in tesi generale che anche le leggi introdutive di nuovi diritti reali, ricevono immediata applicazione. (...) questo sorge nel giorno stesso di quell'attuazione in virtù di un fatto permanente già posto in essere, e sussite finchè dure questo fatto".

${ }^{359}$ in BATALHA, Wilson de Souza Campos. Direito intertemporal, cit., p. 283.
} 
Além disso, as faculdades decorrentes dos direitos reais não têm proteção contra a lei nova porque, quando ainda não exercidas, não constituem direito adquirido, tendo em vista que não existe direito adquirido ao direito objetivo (item 3.5.2). Assim, por exemplo, não se pode invocar a proteção do direito adquirido contra a lei que restringe o direito de construir, pois tal faculdade só se tornaria direito adquirido se o sujeito a houvesse gozado do contrário, constitui mera faculdade jurídica, pertencente apenas ao direito objetivo.

Recorremo-nos novamente ao respaldo de Carlos Francesco Gabba:

\begin{abstract}
"Analogamente ao que dissemos no parágrafo anterior a respeito da introdução de novos direitos reais, e pela mesma razão já exposta, podemos afirmar outrossim que a lei que extingue ou diminui direitos reais possuem aplicação imediata" ${ }^{\text {"360 }}$.
\end{abstract}

Com base nessas premissas e nas regras sobre alteração de prazos (itens 3.3.3, 5.1.3 e 5.1.4), poderão ser resolvidos os principais problemas de direito intertemporal referentes aos direitos reais, sobre os quais discorreremos nos itens seguintes.

\title{
5.5.1. As enfiteuses particulares constituídas antes de 11 de janeiro de 2003 - o artigo
} 2.038

Enfiteuse, aforamento ou emprazamento constitui direito real por meio do qual o proprietário, ou senhorio, atribui a outra pessoa, o enfiteuta, o domínio útil perpétuo sobre bem imóvel não cultivado ou que se destine a edificação, permitindo-lhe usar, gozar e fruir da coisa aforada em troca do pagamento de uma quantia anual certa e invariável, denominada foro ou pensão, mais outra quantia, denominada laudêmio, em caso de transferência do direito enfitêutico, por venda ou dação em pagamento, a pessoa que não seja o próprio senhorio ${ }^{361}$.

\footnotetext{
${ }^{360}$ GABBA, Carlos Francesco. op. cit., v. 3, p. 17. Tradução livre de:"Analogamente a quanto dicemmo nel precedente paragrafo rispetto alla intoduzione di nuovi diritti reali, e per le stesse ragioni ivi esposte, possiamo ora affermare altersì che le leggi abolitive o diminutive di diritti reali ricevono immediata applicazione".

${ }^{361}$ Conforme dispunham os artigos 678, 679, 680 e 686 do Código Civil de 1916: Art. 678: "Dá-se a enfiteuse, aforamento, ou emprazamento, quando por ato entre vivos, ou de última vontade, o proprietário atribui a outrem o domínio útil do imóvel, pagando a pessoa, que o adquire, e assim se constitui enfiteuta, ao senhorio direto uma pensão, ou foro, anual, certo e invariável"; Art. 679: "O contrato de enfiteuse é perpétuo. A enfiteuse por tempo limitado considera-se arrendamento, e como tal se rege"; Art. 680: "Só podem ser objeto de enfiteuse terras não cultivadas ou terrenos que se destinem a edificação"; Art. 686: "Sempre que se realizar a transferência do domínio útil, por venda ou dação em pagamento, o senhorio
} 
Conforme ensina Manoel Antônio Coelho da Rocha, na enfiteuse

\begin{abstract}
"a propriedade plena decompõe-se, para assim dizer, ficando uma parte no antigo senhor, como o direito de pedir o cânon, do laudêmio, da consolidação, e outros, ao que chamamos de domínio direto, ou direitos dominicais; a outra parte passa para o enfiteuta, a qual consiste principalmente na faculdade de cultivar e tirar toda a utilidade, a qual chamamos de domínio útil. O primeiro chama-se senhor direto, ou simplesmente senhorio; o segundo, senhor útil, enfiteuta, foreiro, caseiro.
\end{abstract}

Este contrato difere da locação-condução em que nesta não passa para o colono parte alguma da propriedade, mas apenas o uso (...)"362.

Diferentemente do Código Civil de 1916 (artigos 678 a 694), o Código Civil de 2002 deixou de prever a enfiteuse entre os direitos reais, substituindo-a pelo direito de superfície (artigos 1.369 a 1.377), cujo caráter não-perpétuo se amolda melhor à função social da propriedade. Com isto, o Código Civil de 2002 acabou por extinguir tal instituição jurídica, não permitindo que esta relação-tipo continue a existir no sistema jurídico brasileiro.

Conforme exposto no item 3.5.3, a lei que extingue instituições jurídicas e direitos perpétuos tem efeito imediato e retroativo, inclusive sobre direitos adquiridos. Por esta razão, o Código Civil de 2002 poderia não só impedir a constituição de novas enfiteuses mas também extinguir as existentes em 11 de janeiro de 2003, sem resguardar o direito dos enfiteutas e senhorios - como o fez, por exemplo, a Lei Áurea, impedindo que continuasse a existir qualquer forma de escravidão depois de seu advento.

Contudo, o Código Civil de 2002 houve por bem prever regra transitória segundo a qual as enfiteuses constituídas antes de 11 de janeiro de 2003 continuam reguladas pelo Código Civil de 1916, apesar de proibidas a constituição de subenfiteuses e a cobrança do laudêmio sobre o valor do negócio todo, incluindo as construções e plantações. Em adição, previu ainda que as enfiteuses dos terrenos de marinha serão reguladas por lei especial, como já ocorria no sistema anterior. Dispõe o artigo 2.038:

direto, que não usar da opção, terá direito de receber do alienante o laudêmio, que será de 2,5\% (dois e meio por cento) sobre o preço da alienação, se outro não se tiver fixado no título de aforamento".

${ }^{362}$ in ROCHA, Manoel Antônio Coelho da. Instituições de direito civil. Ed. cuidada por Alcides Tomasetti Jr. São Paulo: Saraiva, 1984. t. 2, p. 305. 
"Art. 2.038. Fica proibida a constituição de enfiteuses e subenfiteuses, subordinando-se as existentes, até sua extinção, às disposições do Código anterior, Lei 3.071, de $1^{\circ}$ de janeiro de 1916, e leis posteriores.

$\S 1^{\circ}$. Nos aforamentos a que se refere este artigo é defeso:

I - cobrar laudêmio ou prestação análoga nas transmissões de bem aforado, sobre o valor das construções ou plantações;

II - constituir subenfiteuse.

$\S 2^{\circ}$. A enfiteuse dos terrenos de marinha e acrescidos regula-se por lei especial"

Como se vê, o Código Civil de 2002 resguarda em parte os direitos dos senhorios e enfiteutas, prevendo fórmula que retira, aos poucos, o interesse econômico da enfiteuse, levando-a à morte por inanição. A nosso ver, andou bem o Legislador, pois, uma vez que a conjuntura o permita, é preferível que se resguarde o direito adquirido dos que se haviam valido de instituição jurídica extinta - o que não ocorreu, por exemplo, quando a Lei Áurea aboliu a escravidão, pois neste caso se fazia necessário conferir personalidade aos escravos, de pronto e de maneira plena.

Contudo, isso não autorizaria os senhorios a pleitearem direitos não contidos no artigo 2.038, caput, como por exemplo o laudêmio sobre o total do negócio. Repita-se, item 3.5.3: $a$ lei que extingue instituições jurídicas e direitos perpétuos tem efeito imediato e retroativo, inclusive sobre direitos adquiridos - se o artigo 2.038, caput, preservou alguns desses direitos, o fez por uma questão de política legislativa, que não autoriza o senhorio a reclamar a incidência do laudêmio sobre construções e plantações, mesmo que prevista contratualmente, na carta de aforamento. Da mesma forma, não poderia o enfiteuta pleitear direito adquirido à constituição de subenfiteuses, proibidas pelo artigo $2.038, \S 2^{\circ}$, inciso II, pela razão retro exposta e porque essa possibilidade constituía mera faculdade jurídica, que pode ser extinta pela lei nova. Vale repisar, item 3.5.2: as faculdades jurídicas ainda não exercidas não constituem direito adquirido, tendo em vista que não existe direito adquirido ao direito objetivo. 


\subsubsection{Os prazos de usucapião alterados pelo Código Civil de 2002 - os artigos 2.028 e 2.029}

Como ensina Silvio Rodrigues, a usucapião é "modo originário de aquisição do domínio, através da posse mansa e pacífica, por determinado espaço de tempo, fixado na lei”363. Trata-se de direito de aquisição por elementos dependentes (item 3.3.2.2), que só se verifica com a conjunção posse + transcurso do tempo. Antes do prazo previsto na lei, não ocorre a aquisição da propriedade, razão pela qual a lei nova deverá ter aplicação imediata, do início de sua vigência em diante, alterando para mais ou para menos o tempo necessário para que se configure a usucapião.

Contudo, assim como se dá com a prescrição, a lei nova não poderia desconsiderar a significação jurídica que o prazo já escoado tinha para o sistema anterior. Por esta razão, também em relação à usucapião deve ser adotada a regra de proporcionalidade enunciada nos itens 3.3.3 e 5.1.3, aos quais fazemos remissão.

O Código Civil de 1916 previa duas formas de usucapião, ordinária e extraordinária.

De acordo com o artigo 551, a usucapião ordinária se consumava no prazo de 10 anos, entre presentes, e de 15, entre ausentes, mediante prova de posse mansa e pacífica com justo título e boa-fé - considerando-se presentes ou ausentes os que habitassem ou não o mesmo Município. Este o texto do revogado artigo 551:

\footnotetext{
"Art. 551. Adquire também o domínio do imóvel aquele que, por 10 (dez) anos entre presentes, ou 15 (quinze) entre ausente, o possuir como seu, contínua e incontestadamente, com justo título e boa-fé.

Parágrafo único. Reputam-se presentes os moradores do mesmo município e ausentes os que habitam município diverso"
}

Já a usucapião extraordinária, tratada no artigo 550, consumava-se no prazo de 20 anos, independentemente de justo título e boa-fé. Dispunha o artigo 550:

"Art. 550. Aquele que, por 20 (vinte) anos, sem interrupção, nem oposição, possuir como seu um imóvel, adquirir-lhe-á o domínio, independentemente de título e boa-fé que, em tal caso, se presume,

\footnotetext{
${ }^{363}$ in RODRIGUES, Silvio. Direito civil: direito das coisas. 27. ed. atual. de acordo com novo Código Civil (Lei n. 10.406, de 10-1-2002). São Paulo: Saraiva, 2002. v. 5, p. 108.
} 
podendo requerer ao juiz que assim o declare por sentença, a qual the servirá de título para transcrição no Registro de Imóveis"

Paralelamente, a Constituição Federal já previa a usucapião especial rural, que se consuma quando pessoa não proprietária de imóvel possua, como se sua fosse, área rural não superior a 50 hectares, por 5 anos ininterruptos, tornando-a produtiva por seu trabalho ou de sua família e nela fixando sua moradia. Dispõe o artigo 191:

“Art. 191. Aquele que, não sendo proprietário de imóvel rural ou urbano, possua como seu, por cinco anos ininterruptos, sem oposição, área de terra, em zona rural, não superior a cinqüenta hectares, tornando-a produtiva por seu trabalho ou de sua família, tendo nela sua moradia, adquirir-lhe-á a propriedade"

Já o Código Civil de 2002 previu 4 formas de usucapião, ordinária, extraordinária, especial rural e especial urbana.

De acordo com o artigo 1.242 do Código Civil de 2002, a usucapião ordinária passou a se consumar aos 10 anos de posse mansa e pacífica com justo título e boa-fé, ou aos 5 caso o imóvel haja sido adquirido onerosamente com base em registro posteriormente cancelado e desde que os possuidores nele tenham estabelecido sua moradia ou realizado investimento de interesse social e econômico. Dispõe o artigo 1.242:

"Art. 1.242. Adquire também a propriedade do imóvel aquele que, contínua e incontestadamente, com justo título e boa-fé, o possuir por 10 (dez) anos.

Parágrafo único. Será de 5 (cinco) anos o prazo previsto neste artigo se o imóvel houver sido adquirido, onerosamente, com base no registro constante do respectivo cartório, cancelada posteriormente, desde que os possuidores nele tiverem estabelecido a sua moradia, ou realizado investimentos de interesse social e econômico"

Já a usucapião extraordinária passou a se consumar em 15 anos, independentemente de justo título e boa-fé, ou em 10 anos caso o possuidor haja feito do imóvel sua moradia habitual ou nele realizado obras ou serviços de caráter produtivo. Dispõe o artigo 1.238 do Código Civil de 2002: 
"Art. 1.238. Aquele que, por 15 (quinze) anos, sem interrupção, nem oposição, possuir como seu um imóvel, adquire-lhe a propriedade, independentemente de título e boa-fé; podendo requerer ao juiz que assim o declare por sentença, a qual servirá de título para o registro no Cartório de Registro de Imóveis.

Parágrafo único. O prazo estabelecido neste artigo reduzir-se-á a 10 (dez) anos se o possuidor houver estabelecido no imóvel a sua moradia habitual, ou nele realizado obras ou serviços de caráter produtivo)".

A par dessas duas espécies, cujos prazos foram reduzidos, o Código Civil de 2002 previu a usucapião especial rural, reproduzindo o texto do artigo 191 da Constituição Federal. Dispõe o artigo 1.239:

“Art. 1.239. Aquele que, não sendo proprietário de imóvel rural ou urbano, possua como sua, por 5 (cinco) anos ininterruptos, sem oposição, área de terra em zona rural não superior a cinqüenta hectares, tornando-a produtiva por seu trabalho ou de sua família, tendo nela sua moradia, adquirir-lhe-á a propriedade.

Além disso, previu a usucapião especial urbana, pela qual o morador de área urbana não superior a 250 metros quadrados adquire a propriedade depois de 5 anos de posse mansa e pacífica, desde que não seja proprietário de outro imóvel. Dispõe o artigo 1.240, caput:

"Art. 1.240. Aquele que possuir, como sua, área urbana de até duzentos e cinqüenta metros quadrados, por 5 (cinco) anos ininterruptamente e sem oposição, utilizando-a para sua moradia ou de sua família, adquirir-lhe-á o domínio, desde que não seja proprietário de outro imóvel urbano ou rural"

Em resumo, com o Código Civil de 2002 os prazos de usucapião passaram a ser os seguintes: na usucapião ordinária, o prazo passou a ser de 10 ou 5 anos, contra os 15 ou 10 do Código Civil de 1916; na usucapião extraordinária, o prazo passou a ser de 15 ou 10 anos, contra os 20 do Código Civil de 1916; como na Constituição Federal, passou-se a prever o prazo de 5 anos para a usucapião especial rural; em adição, estabeleceu-se prazo também de 5 anos para a usucapião especial urbana.

Para contagem desses novos prazos, o Código Civil de 2002 previu regras transitórias, nos artigos 2.028 e 2.029: 
"Art. 2.028. Serão os da lei anterior os prazos, quando reduzidos por este Código, e se, na data de sua entrada em vigor, já houver transcorrido mais da metade do tempo estabelecido na lei revogada".

"Art. 2.029. Até 2 (dois) anos após a entrada em vigor deste Código, os prazos estabelecidos no parágrafo único do art. 1.238, os prazos estabelecidos no parágrafo único do art. 1.238 e no parágrafo único do art. 1.242 serão acrescidos de 2 (dois) anos qualquer que seja o tempo transcorrido, na vigência do anterior, Lei 3.071 , de $1^{\circ}$ de janeiro de 1916".

De tais dispositivos tem-se o seguinte: (1) do artigo 2.028: os prazos novos só serão aplicados caso em 11 de janeiro de 2003 tenha transcorrido menos da metade do prazo anterior, ou seja, 7,5 ou 5 anos da usucapião ordinária e 10 da usucapião extraordinária; e (2) do artigo 2.029: até 11 de janeiro de 2005, os prazos menores da usucapião ordinária ou extraordinária, de 5 e 10 anos, respectivamente (artigos 1.238, parágrafo único, e 1.242, parágrafo único), deverão ser acrescidos de 2 anos, qualquer que seja o prazo já transcorrido portanto, não se aplicando, nesta hipótese, o artigo 2.028. Até 11 de janeiro de 2005 tais prazos serão de 7 e 12 anos, e depois dessa data voltarão a ser de 5 e 10 anos.

A aplicação de tais regras, contudo, merece algumas considerações. A primeira diz respeito ao artigo 2.028, já comentado no item 5.1.4: conforme discorremos ao tratar da prescrição, o artigo 2.028 só terá aplicação em caso de conflito, do qual só se poderá cogitar quando o Código Civil de 2002 houver reduzido um prazo do Código Civil de 1916. Por sua vez, só se poderá falar em redução quando o prazo posterior tiver a mesma natureza do anterior, pois senão se estará diante de direito novo, de aplicação imediata. Assim, o artigo 2.028 só deverá ser aplicado se houver choque prazo de usucapião ordinária x prazo de usucapião ordinária (artigo 1.242 do Código Civil de 2002 x artigo 551 do Código Civil de 1916) ou prazo de usucapião extraordinária x prazo de usucapião extraordinária (artigo 1.238 do Código Civil de 2002 x artigo 550 do Código Civil de 1916). O artigo 2.028 não terá aplicação quando se estiver diante das novas espécies de usucapião, as quais constituem direito novo e possuem pois aplicação imediata.

Neste sentido é a lição do Desembargador Nestor Duarte:

"Necessário, todavia, atentar para a circunstância de que redução do prazo só há entre prazos da mesma classe. Assim, o disposto no artigo 2.028 incide no trato da usucapião extraordinária do Código de 1916 (artigo 550) em relação à extraordinária do novo Código (artigo 1.238) e 
no trato da usucapião ordinária do Código de 1916 (artigo 551) em relação à ordinária do novo Código (artigo 1.242)"364.

A segunda ponderação diz respeito tanto ao artigo 2.028 como ao 2.029: o cômputo dos novos prazos deve ser feita pela regra de proporcionalidade enunciada nos itens $3.3 .3 \mathrm{e}$ 5.1.3. Por exemplo: se antes de 11 de janeiro de 2003 já houvesse transcorrido 10 anos dos 20 anos da usucapião extraordinária do Código Civil de 1916, o usucapiente já teria cumprido metade do prazo necessário para adquirir a propriedade. Como o Código Civil de 2002 não tem efeito retroativo, o novo prazo, de 15, 12 ou 10 anos, não poderá afetar a relação que o tempo tinha para o Código Civil de 1916, de 1/2, a qual deverá ser utilizada para calcular o prazo faltante para a usucapião do Código Civil de 2002. Assim, no caso em exemplo o prazo restante será de 7,5 anos $(15 \times 1 / 2), 6$ anos $(12 \times 1 / 2)$ ou 5 anos $(10 \times 1 / 2)$.

No entanto, os autores vêm adotando outras soluções. No caso do artigo 2.028, a doutrina tem sustentado que o prazo novo deve ser contado a partir de 11 de janeiro de 2003 - a esse respeito, fazemos remissão ao item 5.1.4, onde tratamos especificamente do assunto. No caso do artigo 2.029, há dois posicionamentos a respeito: de um lado, Mário Luiz Delgado sustenta que o acréscimo de 2 anos deve ser feito a partir de 11 de janeiro de 2003, dada a finalidade desse prazo, de evitar que o proprietário seja surpreendido; de outro lado, Maria Helena Diniz sustenta que, dada a finalidade social dos novos prazos, os dois anos deveriam ser somados ao prazo novo, mesmo que isso pudesse levar à imediata usucapião do imóvel. Eis a lição de ambos os autores, na seqüência:

“(...) até 11 de janeiro de 2005 , os prazos estabelecidos no parágrafo único
do art. 1.238 e no parágrafo único do art. 1.242 serão de doze e de sete anos,
respectivamente. E a aplicação desses novos prazos far-se-á
independentemente de haver transcorrido mais ou menos da metade dos
prazos estabelecidos no Código anterior. No caso do parágrafo único do
art. 1.238 , em que o prazo foi reduzido de vinte para dez anos, ou seja,
por mais da metade do prazo velho, não precisará esperar ainda nove
anos, lapso que corresponde ao término da contagem do prazo revogado,
tal como dito no art. 2.028 , mas apenas mais um ano, perfazendo o total
de doze anos (dez anos + dois anos de acréscimo). Questão curiosa vai
surgir, no mesmo exemplo da usucapião extraordinária, se o possuidor já
tiver exercido treze anos de posse quando da entrada em vigor do Código.
Indaga-se: já poderia pedir a sentença declaratória da usucapião? Parece-nos
que não, pois o acréscimo dos dois anos tem a finalidade exatamente de evitar
uma surpresa ao proprietário. Nesse caso, entendemos que o acréscimo dos

${ }^{364}$ in DUARTE, Nestor. Direito intertemporal e prescrição no novo Código Civil, cit., p. 357. 
dois anos será feito, de qualquer forma, contado a partir de 11 de janeiro de $2003^{3,365}$.

“(...) E, se quando a novel lei entrou em vigor, a pessoa já tiver treze anos de posse-trabalho, poderia ela pedir a sentença declaratória de usucapião? Parece-nos que sim, ante a patrimonialidade do prazo, mas há quem entenda, com Mário Luiz Delgado, cuja opinio respeitamos, que aquele acréscimo de dois anos será contado a partir de 11 de janeiro de 2003. Com isso, perguntamos, não se teria um aumento de prazo, 12 para 15 anos, uma vez que já se passaram 13, ferindo a teleologia do novo Código Civil e o princípio da função social da propriedade, consagrado constitucionalmente? Se na posse-trabalho tutela-se o possuidor porque a destinação do imóvel à moradia ou ao trabalho produtivo já se consolidou, não estariam legitimados o privilégio ao princípio da função social da propriedade e o prazo já decorrido sob o império da lei revogada? Se o art. 2.029 admitisse aquela ampliação de prazo, não estaria em conflito com os arts. 1.238, parágrafo único, e 1.242, parágrafo único, gerando, na lição de Engisch, uma antinomia teleológica, por apresentar incompatibilidade com o fim proposto por certas normas (CC, arts. 1.238, parágrafo único, e 1.242, parágrafo único) e o meio previsto por outra (art. 2.029) para alcançar tal finalidade? A relação de meio e fim entre as normas não deveria verificar-se? Também não poderia aquela ampliação instaurar no sistema jurídico uma lacuna axiológica, por acarretar injustiça (LICC, art. $5^{\circ}$ ) ao possuidor que atendeu os requisitos legais? Tal comando da nova lei se deu para atender motivo de relevante valor social. Deveras, segundo Nicola Stolfi, quando uma lei limita a propriedade privada, para satisfazer exigências sociais estenderá seu império inclusive sobre direitos anteriormente constituídos" ${ }^{366}$.

Perceba-se que os autores têm preocupações nobres mas colidentes, as quais poderiam ser atendidas, concomitantemente, se a regra da proporcionalidade fosse adotada. Conforme já argumentamos, as soluções agudas descuidam-se da isonomia, permitindo que a lei nova afete uma parte de maneira desigual em relação à outra. Por esta razão, deveria ser preferida a regra da proporcionalidade, ao que novamente fazemos remissão aos itens 3.3.3, 5.1.3 e 5.1.4.

\subsubsection{O prazo para a desapropriação judicial do artigo $1.228, \S 4^{\circ}$, do Código Civil de 2002 - o artigo 2.030}

Além de reduzir os prazos de usucapião, o Código Civil de 2002 previu forma de desapropriação judicial ou alienação compulsória pela qual o proprietário de extensa área poderá ser privado da coisa se esta for possuída por mais de 5 anos, de forma mansa e

\footnotetext{
${ }^{365}$ in DELGADO, Mário Luiz. op. cit., p. 67.

${ }^{366}$ in DINIZ, Maria Helena. Código Civil anotado. 10. ed. São Paulo: Saraiva, 2004. p. 1.478.
} 
pacífica, por considerável número de pessoas que nela tenha realizado obras e serviços considerados pelo Juiz de interesse social e econômico relevante. Dispõe o artigo $1.228, \S 4^{\circ}$ :

"Art. 1.228. O proprietário tem a faculdade de usar, gozar e dispor da coisa, e o direito de reavê-la do poder de quem quer que injustamente a possua ou detenha.

\section{$(\ldots)$}

$\S 4^{\circ}$. O proprietário também pode ser privado da coisa se o imóvel reivindicado consistir em extensa área, na posse ininterrupta e de boa-fé, por mais de 5 (cinco) anos, de considerável número de pessoas, e estas nela houverem realizado, em conjunto ou separadamente, obras e serviços considerados pelo juiz de interesse social e econômico relevante".

Este prazo, de 5 anos, também deverá sofrer o acréscimo referido no artigo 2.029, conforme prevê o artigo 2.030:

"Art. 2.030. O acréscimo de que trata o artigo antecedente, será feito nos casos a que se refere o $\S 4^{\circ}$ do art. 1.228".

Daí que, até 11 de janeiro de 2005, o prazo da desapropriação judicial ou alienação compulsória será de 7 anos, voltando a ser de 5 depois dessa data. Em qualquer caso, por se tratar de direito novo, o prazo deverá ser contado a partir de 11 de janeiro de 2003.

\subsection{Direito de Família}

O Direito de Família é o mais publicizado dos ramos do Direito Civil, proclamando o Constituinte que "a família, base da sociedade, tem especial proteção do Estado" (artigo 226, caput, da Constituição Federal). Mais que direitos, as regras de direito de família estipulam deveres, proibições e faculdades ${ }^{367}$, que pertencem apenas ao direito objetivo e não podem ser reclamados como patrimônio de ninguém - não se enquadrando, pois, no conceito de direito adquirido (item 3.5.2).

\footnotetext{
${ }^{367}$ Afirma Silvio Rodrigues: “(...) todo o direito familiar se desenvolve e repousa na idéia de que os vínculos são postos e as faculdades conferidas não tanto para atribuir direitos quanto para impor deveres. (...)" (in RODRIGUES, Silvio. Direito civil: direito de família. 27. ed. atual. por Francisco José Cahali; com anotações sobre o novo Código Civil (Lei n. 10.406, de 10-1-2002). São Paulo: Saraiva, 2002. v. 6, p. 12).
} 
Tal peculiaridade demanda que, em direito de família - como em todo o sistema de direito intertemporal, mas aqui com maior cuidado -, o intérprete adote a seguinte solução: os deveres, proibições e faculdades ainda não exercidas devem ser analisados segundo a lei que os ventilar, mesmo que atinjam relações iniciadas antes de seu advento (item 3.5.2). Apenas direitos adquiridos e atos jurídicos perfeitos devem continuar regidos pela lei antiga, o que em direito de família se afigura uma exceção.

Por essa razão é que, e.g., as faculdades do divórcio e de alteração do regime de bens devem ser permitidas também aos cônjuges unidos antes das leis que as instituíram. $\mathrm{O}$ reverso seria verdadeiro: se, por hipótese, lei posterior à união extinguisse as faculdades do divórcio e de alteração do regime de bens, os cônjuges não poderiam pretender exercê-las, mesmo que se tenham casado sob ordenamento que as permitia.

Por outro lado, não poderiam ser atingidos pela lei nova o casamento já levado a efeito (por exemplo, estabelecendo-se um novo impedimento matrimonial), o regime de bens, legal ou convencional, as disposições antenupciais validamente estipuladas, o filho já reconhecido, a habilitação já concluída, o divórcio já realizado etc ${ }^{368}$; não poderia a lei nova validar ou invalidar atos já concluídos, suprimindo ou estabelecendo requisitos para sua realização. Todas essas são hipóteses de faculdades já exercidas, e protegidas, pois, contra o advento de novas leis. No dizer de Rubens Limongi França, são faculdades jurídicas concretas, que constituem direitos adquiridos e não sofrem incidência da lei nova ${ }^{369}$.

\subsubsection{A lei aplicável ao regime de bens do casamento}

Regime de bens é o conjunto de regras que disciplina os aspectos patrimoniais do casamento, determinando, entre outras coisas, a titularidade e a forma de administração dos bens dos cônjuges.

\footnotetext{
${ }^{368}$ Elucidativa a lição de Carlos Maximiliano: “Atos jurídicos definitivamente completados sob o império da lei anterior e de acordo com a mesma, continuam em integral validade na vigência de norma posterior e contrária. Assim acontece no tocante ao casamento, divórcio, desquite (por mútuo consentimento, por exemplo, admitido nuns países e repelido noutros), adoção, legitimação, reconhecimento de paternidade e interdição. Por consequiência, realizados os pressupostos para a constituição de família, esta existe, e o conseqüente estado das pessoas não mais pode ser impugnado, constitui verdadeiro direito adquirido (...)" (in MAXIMILIANO, Carlos. op. cit., p. 80).

${ }^{369}$ in FRANÇA, Rubens Limongi. Direito intertemporal brasileiro: doutrina da irretroatividade das leis e do direito adquirido, cit., p. 449-450.
} 
Adotado um determinado regime de bens, surge para os cônjuges uma série de direitos (por exemplo, a comunicabilidade, na meação, de uma dada categoria de bens), os quais são regulados, em regra, pela lei vigente ao tempo do casamento. Protege-se a liberdade dos cônjuges de disporem livremente de seus bens, impedindo-se que a lei nova possa se voltar contra ato perfeito sob a égide da lei anterior.

Nesse sentido, dispõe o artigo 2.039 do Código Civil de 2002:

"O regime de bens nos casamentos celebrados na vigência do Código Civil anterior, Lei 3.071, de $1^{\circ}$ de janeiro de 1916, é o por ele estabelecido".

Assim, por exemplo, os cônjuges casados no regime legal da comunhão universal não passarão, com o Código Civil de 2002, a viver sob o regime da comunhão parcial, que veio a ser o regime legal de bens, segundo o artigo 1.640; os proventos do trabalho dos cônjuges casados no regime da comunhão parcial de bens sob a égide do Código Civil de 1916 continuarão a se comunicar com os do outro, nos termos do artigo 271, inciso VI, do Código Civil de 1916, apesar de o artigo 1.659, inciso VI, do Código Civil de 2002, trazer disposição em contrário.

Contudo, não é exato supor que qualquer questão ligada ao regime de bens esteja ao abrigo da lei nova, dado que o regime de bens gera para os cônjuges não só direitos mas também faculdades, deveres e proibições. As faculdades ainda não exercidas, os deveres e as proibições devem ser analisados sob a ótica da lei nova, mesmo que atinjam relações iniciadas no passado. Vale repetir, apenas os direitos adquiridos, o ato jurídico perfeito e a coisa julgada obstam a incidência da lei nova ${ }^{370}$.

Assim, por exemplo, um cônjuge não poderá prestar aval sem o consentimento do outro, conforme prescreve o artigo 1.647, inciso III, do Código Civil de 2002, mesmo que se tenha casado na vigência do Código Civil de 1916, que não o exigia; o cônjuge casado no regime da separação de bens antes de 11 de janeiro de 2003 poderá alienar livremente seus

\footnotetext{
${ }^{370}$ Wilson de Souza Campos Batalha afirmava que apenas as disposições de natureza contratual é que se subordinam aos ditames da lei revogada, tenham ou não sido estipuladas por meio de pacto antenupcial. Sustenta que o que for estatutário sofre a incidência da lei nova - no que, a nosso ver, está a afirmar que as meras faculdades, as proibições e os deveres dos cônjuges serão os que a lei nova impuser, independentemente do regime de bens adotado (in BATALHA, Wilson de Souza Campos. Direito intertemporal, cit., p. 261-262).
} 
bens imóveis, sem autorização do outro, nos termos do artigo 1.687 do Código Civil de 2002, embora o artigo 276 do Código Civil de 1916 dispusesse em sentido contrário ${ }^{371}$. O mesmo raciocínio se aplica à possibilidade de alteração do regime de bens anterior ao Código Civil de 2002, do que se tratará no item seguinte. São situações referentes ao regime de bens, mas que sofrem incidência da lei nova por não constituírem direito adquirido, ato jurídico perfeito ou coisa julgada.

O artigo 2.039 do Código Civil não poderá ser analisado literal e friamente, como se qualquer anterior disposição concernente ao regime de bens devesse ser regulada pelo Código Civil de 1916. Apenas o ato jurídico perfeito, o direito adquirido e a coisa julgada é que não sofrerão a incidência do Código Civil de 2002.

\subsubsection{A possibilidade de alteração do regime de bens anterior ao Código Civil de 2002}

Antes do Código Civil de 2002, vigia o sistema da imutabilidade do regime de bens, pelo qual os nubentes não poderiam alterá-lo após a realização do casamento ${ }^{372}$. Depois de casados, o regime escolhido não poderia ser alterado, perdurando durante toda a existência da sociedade conjugal.

O Código Civil de 2002 veio dispor que, uma vez casados, os cônjuges têm a faculdade de requerer a alteração do regime anteriormente escolhido, desde que o façam mediante autorização judicial, em pedido motivado de ambos os cônjuges, apuradas as razões invocadas e resguardados os direitos de terceiros ${ }^{373}$. Dispõe o artigo $1.639, \S 2^{\circ}$ :

“Art. 1.639. É lícito aos nubentes, antes de celebrado o casamento, estipular, quanto aos seus bens, o que lhes aprouver.

\footnotetext{
${ }^{371}$ Os exemplos são de Silmara Juny de Abreu Chinellato (in CHINELLATO, Silmara Juny de Abreu. Direito patrimonial de família. In: DELGADO, Mário Luiz; ALVES, Jones Figueiredo (Coords.). Questões controvertidas no novo Código Civil. São Paulo: Método, 2005. v. 3, 155).

${ }^{372}$ Artigo 230 do Código Civil de 1916: "O regime dos bens entre cônjuges começa a vigorar desde a data do casamento, e é irrevogável".

Artigo 256, caput, do Código Civil de 1916: "É lícito aos nubentes, antes de celebrado o casamento, estipular, quanto aos seus bens, o que lhes aprouver (arts. 261, 273, 277, 283, 287 e 312)".

${ }^{373}$ Como observa Carlos Roberto Gonçalves, "O Código Civil de 2002, dessarte, inovou, substituindo o princípio da imutabilidade absoluta do regime de bens pelo da mutabilidade motivada ou justificada. A inalterabilidade continua sendo a regra e a mutabilidade a exceção, pois esta somente pode ser obtida em casos especiais, mediante sentença judicial, depois de demonstrados e comprovados, em procedimento de jurisdição voluntária, a procedência da pretensão bilateralmente manifestada e o respeito a direitos de terceiros" (in GONÇALVES, Carlos Roberto. Direito civil brasileiro: direito de família. São Paulo: Saraiva, 2005. v. 6, p. 385).
} 


\title{
$(\ldots)$
}

$\S 2^{\circ}$. É admissível alteração do regime de bens, mediante autorização judicial em pedido motivado de ambos os cônjuges, apurada a procedência das razões invocadas e ressalvados os direitos de terceiros".

Ante o disposto no artigo 2.039 do Código Civil, transcrito no item anterior, a doutrina vem procurando uma forma de estender a aplicação do dispositivo aos casamentos celebrados antes de 11 de janeiro de 2003.

Uma primeira corrente sustenta que o artigo 2.039 teria se ocupado apenas dos aspectos específicos de cada regime, estabelecidos nos artigos 1.658 a 1.688 , não se estendendo às disposições gerais dos regimes de bens, apostas nos artigos 1.639 a 1.657 . Os partidários dessa corrente argumentam que as disposições gerais seriam distintas e independentes das regras que compõem os regimes de bens, e apenas estes, especificamente considerados, é que estariam insertos na disposição transitória do artigo 2.039.

Nesse sentido é o entendimento de Mário Luiz Delgado:

\begin{abstract}
“(...) Por ora, manifestamos posição no sentido de que as disposições gerais sobre regimes de bens previstas nos arts. 1.639 a 1.657 seriam aplicáveis a todos os casos, inclusive para os casamentos celebrados anteriormente a 11 de janeiro de 2003. Entre outras razões, porque o art. 2.039 parece referir-se a regras específicas de cada regime, e não às disposições gerais comuns a todos os regimes. As disposições constantes dos arts. 1.639 a 1.657 são distintas e independentes daquelas que compõem os regimes de bens propriamente ditos. Integram o chamado regime matrimonial primário e prescrevem os princípios aplicáveis à sociedade conjugal, do ponto de vista dos seus interesses patrimoniais. Disciplinam, no âmbito da sociedade conjugal, a propriedade, a administração, o gozo e a disponibilidade dos bens e obrigações que os cônjuges podem ou não assumir, qualquer que seja o regime de bens. (...)

Daí por que entendemos que a norma transitória do art. 2.039 não poderia estar se referindo senão aos arts. 262 a 314 do CC/1916 (CC/2002, arts. 1.658 a 1.688), excluindo de seu campo de incidência as chamadas disposições gerais (CC/1916, arts. 256 a 261, e CC/2002, arts. 1.639 a 1.657), do que se deflui serem tais regras aplicáveis até mesmo aos casamentos celebrados antes de 11 de janeiro de $2003^{, 374}$.
\end{abstract}

\footnotetext{
${ }^{374}$ in DELGADO, Mário Luiz. op. cit., p. 132-133. No mesmo sentido, Nelson Rosenvald: “(...) o art. 2.039 só se ocupou em resguardar os aspectos específicos de cada regime matrimonial. Ou seja, as inovações nas disposições gerais comuns a todos os regimes de bens (arts. 1.639 a 1.652 do CC) se estendem aos que casaram antes de 11.01.2003. Fundamental é diferenciar o regime matrimonial primário - estatuto genérico sobre a disciplina econômica do casal em qualquer regime de bens - do regime matrimonial secundário,
} 
Por sua vez, uma segunda corrente doutrinária sustenta que o novel artigo 1.639, § $2^{\circ}$, teria natureza processual e portanto se aplicaria às relações em curso, atingindo os casamentos celebrados antes do início da vigência do Código Civil de 2002. Este é o entendimento de Antonio Jeová Santos:

"Quando o § 2. ${ }^{\circ}$ dispõe que os cônjuges, conjuntamente, devem apresentar ao juiz pedido motivado, o que significa é que criada foi uma ação judicial para remover o óbice do anterior regime em que havia uma blindagem quanto ao regime de bens convencionado pelos nubentes.

E se a mudança de regime de bens somente pode ser concretizada mediante sentença judicial, não dependendo apenas da autonomia da vontade do casal, esta regra é de natureza vistosamente processual e, como tal, sua aplicação é imediata. Abarca todos os casamento aqueles celebrados antes da vigência do Código Civil de 2002, inclusive.

\section{$(\ldots)$}

Sendo possível a apresentação de ação judicial, providência que será de jurisdição voluntária, porque o pedido tem de ser feito por ambos os cônjuges, não havendo litígio a ser dirimido, o que era juridicamente impossível pela vedação do art. 230 do CC/1916, a regra, atualmente, é basicamente de direito processual e, como tal, alcança a todos, incluindose aqueles que se casaram antes do advento do Código Civil de 2002,375.

Há ainda quem chegue à mesma conclusão utilizando-se do princípio da igualdade, que não permitiria dar tratamento distinto aos cônjuges casados antes ou depois de 11 de janeiro de 2003. Este o posicionamento de Euclides de Oliveira:

\footnotetext{
"Torna-se impositivo interpretar a referida norma legal dentro do princípio igualitário, sem diferenciação de casamentos por sua data e tendo em vista a ampla possibilidade de mudança de regime de bens formada pela união estável. Ademais, a exegese dos dispositivos legais deve ser feita à luz do fim social da norma jurídica, propiciando, no caso, atendimento equânime aos interesses das pessoas casadas na preservação da unidade familiar pelo regime de bens que lhes seja de efetivo interesse e utilidade" ${ }^{\prime 376}$.
}

alusivo à especificidade de cada regime de bens (arts. 1.658 a 1.688 do CC)" (in ROSENVALD, Nelson. Código Civil comentado: doutrina e jurisprudência. Coord. Cezar Peluso. Barueri: Manole, 2007. p. 1.974).

${ }^{375}$ in SANTOS, Antonio Jeová. op. cit., p. 167-169. No mesmo sentido, Nelson Rosenvald afirma: "demandando sentença judicial, temos que a regra de alteração do regime é lei processual e possui eficácia imediata ao abranger as situações jurídicas de direito material anteriores ao Código Civil de 2002. A referida lei, portanto, supre condição da ação anteriormente inexistente, qual seja, a possibilidade jurídica do pedido (...)". (in ROSENVALD, Nelson. op. cit., p. 1.975).

${ }^{376}$ in OLIVEIRA, Euclides de. Alteração do regime de bens no casamento. In: DELGADO, Mário Luiz; ALVES, Jones Figueiredo (Coords.). Questões controvertidas no novo Código Civil. São Paulo: Método, 2003. p. 404. 
A nós, parece-nos uma questão simples e que não exige lucubrações: conforme tratado no item 3.5.2, as meras faculdades jurídicas não estão protegidas contra a lei nova, pois não existe direito adquirido ao direito objetivo. Por essa razão, a lei que veda ou estabelece faculdades jurídicas deverá ser aplicada a todas as relações, inclusive às que tenham se iniciado no passado. Se a lei nova vem permitir ou proibir uma faculdade ainda não exercida, não há nenhum óbice - direito adquirido, ato jurídico perfeito ou coisa julgada - que impeça sua incidência.

A regra do artigo 2.039 não discrepa. Ao dispor que os regimes anteriores devem ser regulados pela lei antiga, o artigo 2.039 tem em vista garantir proteção ao direito adquirido dos cônjuges de regularem-se pelas regras vigentes no momento do casamento, e não proibir que estes mesmos cônjuges - daí por vontade própria - não pudessem alterar o regime anteriormente escolhido, conforme veio facultar o artigo 1.638, $\S 2^{\circ}$, do Código Civil de 2002. Como regra transitória que é, o artigo 2.039 veio conferir segurança aos cônjuges casados antes de 11 de janeiro de 2003, e não impedir que pudessem gozar sponte sua - das faculdades estabelecidas pela nova lei civil ${ }^{377}$.

Assim como aconteceria com qualquer outra faculdade jurídica, não existe direito adquirido à modificabilidade do regime de bens, razão pela qual a lei nova deve incidir sobre todos os casamentos, mesmo que anteriores ao seu advento. Data venia, não há razão para se supor que, mesmo sendo uma regra transitória, o artigo 2.039 tivesse pretendido algo além de proteger direitos e garantir segurança às relações anteriores ao advento do novo Código Civil.

Nosso entendimento se alinha ao de Silmara Juny de Abreu Chinelato, que, distinguindo efeito imediato e retroativo, conclui cientificamente que a regra do artigo 2.039 só tem lugar quando se estiver diante de direitos adquiridos:

“Assim sendo, tanto para os que perfilham tal tese como para mim, que
enfatizo a aplicação imediata da lei nova - o que não se confunde com
retroatividade -, a mutabilidade do regime de bens alcança os casamentos
celebrados na vigência do Código de 1916 , devendo os interessados
requerer a mudança ao juiz, em pedido justificado, conforme $\S 2^{\circ}$ do art.

\footnotetext{
${ }^{377}$ Oportuna a afirmação da Desembargadora Maria Berenice Dias: "A possibilidade de alteração do regime matrimonial de bens conferida aos cônjuges pelo Código Civil não afronta o ato jurídico perfeito e o direito adquirido. Houve uma otimização do princípio da autonomia da vontade do casal, consagrado no princípio da livre estipulação do pacto (art. 1.639 do Código Civil), de forma que se revela descabido afastar tal ampliação de direitos dos casamentos celebrados sob a égide do antigo estatuto civil" (TJ/RS, $7^{\mathrm{a}}$ Câm. Cív., Ap. Cív. no 70011082997, Rel. Des. Maria Berenice Dias, j. 1.6.2005, v.u).
} 
1.639. Uma vez deferida, vigorará a partir de então e esse novo regime seguirá aos ditames do Código Civil ora em vigor" ${ }^{\text {"378 }}$.

Wilson de Souza Campos Batalha já considerava absurda a idéia de um "direito adquirido à modificabilidade do regime de bens". Sustentando a aplicação imediata, inclusive às relações em curso, da lei proíbe ou permite a alteração do regime de bens, o autor afirma:

“(...) Entendemos, ao contrário, que têm efeito imediato as leis que estabelecem a mutabilidade ou a imutabilidade das convenções matrimoniais. Nenhuma razão sólida existe para diverso entendimento. Na hipótese de a lei nova estabelecer a mutabilidade do regime, não há motivo algum para inaplicar-se aos regimes em curso: se aos interessados era facultada inicialmente a eleição do regime aplicável, não se vê por que se lhes iria tolher a faculdade, que a lei nova, por hipótese, consagra, de voluntariamente, alterarem o pacto antenupcial. Se, ao contrário, a lei nova estabelece a imutabilidade do regime, não mais poderão ser modificados os regimes estabelecidos na vigência da lei que o permitia, por se deverem generalizar as razões que levaram o legislador a estabelecer a imutabilidade da convenção matrimonial; seria absurdo falar-se em direito adquirido à modificabilidade da convenção matrimonial (...)"379.

Os Tribunais têm decidido ser possível a modificação do regime de bens dos casamentos anteriores ao Código Civil de 2002, por inexistir afronta a direito adquirido. A propósito, julgados relatados pela Ministra Nancy Andrighi, do Superior Tribunal de Justiça, e pelo Desembargador José Ataídes Siqueira Trindade, do Tribunal de Justiça do Rio Grande do Sul:

"Direito civil. Família. Casamento celebrado sob a égide do CC/16. Alteração do regime de bens. Possibilidade.

- A interpretação conjugada dos arts. $1.639, \S 2^{\circ}, 2.035$ e 2.039 , do $\mathrm{CC} / 02$, admite a alteração do regime de bens adotado por ocasião do matrimônio, desde que ressalvados os direitos de terceiros e apuradas as razões invocadas pelos cônjuges para tal pedido.

- Assim, se o Tribunal Estadual analisou os requisitos autorizadores da alteração do regime de bens e concluiu pela sua viabilidade, tendo os cônjuges invocado como razões da mudança a cessação da incapacidade civil interligada à causa suspensiva da celebração do casamento a exigir a adoção do regime de separação obrigatória, além da necessária ressalva quanto a direitos de terceiros, a alteração para o regime de comunhão parcial é permitida.

\footnotetext{
${ }^{378}$ in CHINELLATO, Silmara Juny de Abreu. op. cit., p. 156.

${ }^{379}$ BATALHA, Wilson de Souza Campos. Direito intertemporal, cit., p. 262.
} 
- Por elementar questão de razoabilidade e justiça, o desaparecimento da causa suspensiva durante o casamento e a ausência de qualquer prejuízo ao cônjuge ou a terceiro, permite a alteração do regime de bens, antes obrigatório, para o eleito pelo casal, notadamente porque cessada a causa que exigia regime específico.

- Os fatos anteriores e os efeitos pretéritos do regime anterior permanecem sob a regência da lei antiga. Os fatos posteriores, todavia, serão regulados pelo $\mathrm{CC} / 02$, isto é, a partir da alteração do regime de bens, passa o CC/02 a reger a nova relação do casal.

- Por isso, não há se falar em retroatividade da lei, vedada pelo art. $5^{\circ}$, inc. XXXVI, da CF/88, e sim em aplicação de norma geral com efeitos imediatos" ${ }^{380}$.

"O art. 2.039 das Disposições Finais e Transitórias do Código Civil em vigor não impede a alteração do regime de bens nos casamentos celebrados na vigência do Código Civil de 1916. O regime de bens dos casamentos pela antiga lei é o por ele estabelecido, mas somente enquanto não se aplicar a regra geral do art. $1.639, \S 2 .^{\circ}, \mathrm{CC} / 02$, ou seja, enquanto não optarem os cônjuges pela sua alteração, até porque, o art. 2.039 não diz que o regime do casamento contraído pelo $\mathrm{CC} / 16$ é imutável ou irrevogável",381.

Tais julgados deixam claro que uma interpretação sistemática não permitiria concluir que o artigo 2.039 tivesse pretendido proibir a aplicação do artigo 1.639, § $2^{\circ}$, aos cônjuges casados antes do advento do Código Civil de 2002.

\subsubsection{A lei aplicável ao regime patrimonial das uniões estáveis anteriores ao Código Civil de 2002 e às Leis no 8.791/94 e 9.278/96}

Até a Constituição Federal de 1988, a união estável não era reconhecida como entidade familiar. A jurisprudência a reconhecia apenas como sociedade de fato, atribuindo-lhe efeitos patrimoniais. De acordo com a Súmula $n^{\circ} 380$ do STF, os então denominados concubinos gozavam tão-somente do direito de partilhar o patrimônio comum, ou seja, adquirido com o esforço direto de ambos os conviventes.

Com o reconhecimento da união estável (artigo 226, § $3^{\circ}$, da Constituição Federal), a Lei $\mathrm{n}^{\mathrm{o}} 8.971 / 94$ veio conferir ao companheiro direito de meação sobre os bens adquiridos em mútua colaboração (artigo $3^{\circ}$ ), isto é, adquiridos não só pelo esforço direto mas também

\footnotetext{
${ }^{380}$ STJ, $3^{\text {a }}$ Turma, REsp 821807/PR, Rel. Min. Nancy Andrighi, j. 19.10.2006, v.u.

${ }^{381}$ TJ/RS, 8 a Câm. Cív., Ap. Cív. no 70010050441, Re. Des. José Ataídes Siqueira Trindade, j. 31.3.2005, v.u.
} 
por contribuições indiretas dos conviventes - por exemplo, o auxílio no lar, educação dos filhos etc ${ }^{382}$.

Por sua vez, a Lei n 9.278/96 estabeleceu a presunção de que "os bens móveis e imóveis adquiridos por um ou por ambos os conviventes na constância da união estável e a título oneroso são considerados fruto do trabalho e da colaboração comum" (artigo $5^{\circ}$, primeira parte), conferindo ao companheiro direito de meação em partes iguais, independentemente de prova do esforço direito ou indireto (artigo $5^{\circ}$, segunda parte).

Já o Código Civil de 2002 dispôs que, salvo contrato escrito entre as partes, aplicase à união estável o regime da comunhão parcial de bens, no que couber (artigo 1.725). Ante tal estipulação, o companheiro terá direito de meação sobre todos os bens que sobrevierem ao início da união estável, exceto os adquiridos a título gratuito, por doação ou por herança, e os sub-rogados no lugar de bens particulares, nos termos dos artigos 1.658 a 1.666 do Código Civil de 2002.

Diante dessas alterações legislativas, a pergunta: aplica-se a lei nova quando da dissolução de união estável iniciada antes de seu advento, mesmo com relação ao regime patrimonial? Ou, em outros termos: os bens adquiridos durante a união estável devem ser partilhados de acordo com a lei vigente quando de sua aquisição ou conforme determinar a lei em vigor ao tempo da dissolução?

A doutrina tem sustentado que a lei vigente no momento da dissolução recairia apenas sobre os aspectos pessoais da união estável (por exemplo, o direito a alimentos), aplicando-se ao regime patrimonial a lei em vigor ao tempo da aquisição de cada bem a ser partilhado. Argumenta, esta linha respeitável de juristas, que a divisão dos bens pela lei vigente ao tempo da dissolução representaria ofensa ao direito adquirido, pois sua titularidade teria se ultimado em momento anterior ao início da vigência da nova lei.

Assim, se adquirido antes da Lei $\mathrm{n}^{\circ}$ 8.971/94, o bem haveria de ser partilhado de acordo com a Súmula $n^{\circ} 380$ do STF; se adquirido entre as Leis $n^{\circ}$ 8.971/94 e 9.278/96, conforme os ditames da Lei $n^{\circ}$ 8.971/94; se adquirido entre a Lei $n^{\circ}$ 9.278/96 e o Código Civil de 2002, de acordo com o que dispõe a Lei $n^{\circ}$ 9.278/96; e, se adquirido depois do início da vigência do Código Civil de 2002, de acordo com este.

\footnotetext{
${ }^{382}$ Embora, a princípio, a Lei $\mathrm{n}^{\circ} 8.971 / 94$ se aplicasse apenas em caso de sucessão do companheiro, a jurisprudência acabou por estendê-la à dissolução das uniões estáveis.
} 
Em dissertação dedicada especialmente ao tema, Simone Orodeschi Ivanov dos Santos resume o pensamento da doutrina majoritária, da qual é partidária:

“(...) deverá se verificar a data em que cada bem foi adquirido durante a união, para que sejam aplicadas as regras vigentes na época de sua aquisição.

A lei nova deve respeitar o princípio da irretroatividade, sendo admitida pelo artigo $6^{\circ}$ da Lei de Introdução ao Código Civil sua aplicação imediata aos fatos pendentes, ou seja, às situações ou relações iniciadas sob a égide da lei anterior e que perduram sob o período de vigência da lei nova.

Dessa forma, a lei nova terá aplicação às uniões estáveis em curso. Porém, isso não significa que os preceitos da nova lei se estenderão a todos os efeitos jurídicos da união estável (...).

\section{(...)}

A incidência das regras do regime patrimonial criado pelo novo Código Civil só recairá sobre os bens adquiridos a partir da entrada em vigor desse novo diploma legislativo. Isso ocorre porque os bens, no momento em que são adquiridos, têm sua titularidade determinada, configurando ato jurídico perfeito.

A seu turno, a situação jurídica dos bens que foram adquiridos antes da entrada em vigor do Código Civil de 2002 deverá ser disciplinada pela lei que estava em vigor na época do seu nascimento, havendo ultratividade desse diploma legal.

Assim, a situação jurídica de um bem que foi adquirido em 1980, durante uma união estável que ainda perdura, segue as regras da Súmula n. 380 do Supremo tribunal ( $s i c$ ) Federal. Já a situação jurídica de um bem que foi adquirido em 1997, obedece às regras da Lei n. 9.278/96"383.

Com o devido respeito, o entendimento não deve ser seguido, pois a alteração do regime patrimonial não implica ofensa a direitos adquiridos: a titularidade dos bens é um direito do casal, e não somente do companheiro que os registrou - tanto que, se quisessem, os companheiros poderiam ressalvar a aplicação da nova lei, por meio de contrato escrito, atribuindo os bens a apenas um deles.

\footnotetext{
${ }^{383}$ SANTOS, Simone Orodeschi Ivanov dos. Regime Patrimonial na união estável e direito intertemporal. 2004. Dissertação (Mestrado) - Faculdade de Direito, Pontifícia Universidade Católica de São Paulo, São Paulo, 2004. No mesmo sentido, Carlos Roberto Gonçalves (in GONÇALVES, Carlos Roberto. Direito civil brasileiro: direito de família, cit., p. 566-567), Francisco José Cahali (CAHALI, Francisco José. Contrato de convivência na união estável. São Paulo: Saraiva, 2002. p. 155) e Euclides de Oliveira (in OLIVEIRA, Euclides de. União estável: do concubinato ao casamento, antes e depois do novo Código Civil. 6. ed. São Paulo: Método, 2003. p. 115).
} 
Data venia, a afirmação de que a lei nova não se aplica ao regime patrimonial da união estável representa visão individualista. É afirmar que, para efeitos patrimoniais, os companheiros continuaram sendo apenas "sócios" no que toca aos bens adquiridos antes do advento da Constituição Federal de 1988; seria dizer que não há plena comunhão de vida entre os companheiros unidos antes do Código Civil de 2002. Com razão está o Desembargador Luiz Felipe Brasil Santos, do Tribunal de Justiça do Rio Grande do Sul, ao afirmar que

\begin{abstract}
"tendo a sociedade de fato decorrente da convivência 'more uxorio' iniciado antes da Constituição Federal, mas terminado já sob a égide da Lei $n^{\circ}$ 9278/96, aplicam-se as disposições desta lei para reger a sociedade desavinda. A natureza da relação iniciada antes da Carta Magna não sofreu alteração alguma, apenas conquistou a respeitabilidade social que sempre lhe foi devida além da indispensável proteção e regulamentação jurídica, assemelhando-se em tudo ao casamento civil ${ }^{\prime 384}$.
\end{abstract}

Como a união estável é relação continuativa, seus efeitos sujeitam-se às alterações legislativas que ocorrerem em seu curso. Se a lei nova atribui ao convivente o status de companheiro, não poderia fazê-lo pela metade, excluindo os aspectos patrimoniais companheiro nas lutas e sócio no patrimônio. O patrimônio do casal é um direito adquirido do casal, mesmo que esta condição só tenha sido reconhecida depois da aquisição do bem.

As leis que se seguiram à Constituição Federal não alteraram a titularidade dos bens dos partícipes da união estável, mas somente estabeleceram um sistema de presunções que paulatinamente levaria à equiparação com o casamento - com a Lei n ${ }^{\circ} 8.971 / 94$, estabeleceuse a presunção de que as contribuições indiretas também constituiriam esforço comum; a Lei $\mathrm{n}^{\circ}$ 9.278/96 veio presumir comuns os bens adquiridos onerosamente ao longo da convivência, independentemente de prova do esforço direito ou indireto; por fim, o Código Civil de 2002 equiparou, definitivamente, o regime patrimonial da união estável ao regime da comunhão parcial de bens.

Ora, seria absurdo falar-se em direito adquirido a um sistema de presunções. As presunções são as que determinar a lei vigente ao tempo da produção da prova, e não as existentes ao tempo da ocorrência do fato probando. Logo, não pode o companheiro se valer da presunção da Súmula n 380 do STF se a prova da aquisição do bem tiver de ser feita após o advento da Lei $n^{\circ} 8.971 / 94$; igualmente, não poderá se pautar no texto da Lei

\footnotetext{
${ }^{384}$ TJ/RS, 7 a Câm. Cív., Ap. Cív. n 599387677, Rel. Des. Luiz Felipe Brasil Santos, j. 06/10/1999, v.u..
} 
$\mathrm{n}^{\mathrm{o}}$ 8.971/94 se a prova houver de ser produzida na vigência da Lei $\mathrm{n}^{\circ}$ 9.278/96 ou do Código Civil de 2002.

Especificamente no caso da Súmula 380 do STF, há o equívoco gritante de se pretender um direito adquirido a entendimento jurisprudencial. Data venia, não se pode pretender a aplicação de uma súmula contra lei posterior que lhe contrarie o texto. Não existe ultratividade de entendimento jurisprudencial.

Não há argumento substancial ou de ordem processual a justificar a não-incidência da lei nova ao regime patrimonial das uniões estáveis.

\subsubsection{A lei aplicável às questões pessoais do direito de família}

As questões pessoais do direito de família dizem respeito a deveres, proibições e faculdades - os quais, repita-se, não gozam da proteção conferida ao direito adquirido, ao ato jurídico perfeito e à coisa julgada -, e são disciplinadas, pois, pela lei vigente ao tempo em que se desenvolverem (item 3.5.2). Nesse contexto, a lei nova regulará, do início de sua vigência em diante, o poder familiar, a relação pessoal entre os cônjuges, os deveres e direitos de cada consorte, os efeitos da adoção já realizada, a tutela e a curatela, o direito a alimentos, a administração dos bens dos filhos e as relações entre os genitores e a prole salvo, neste último caso, se houver acordo dispondo em sentido contrário.

Assim, por exemplo, o alimentante poderá pedir exoneração dos alimentos devidos em razão do poder familiar se o alimentando tiver mais de dezoito anos na data da entrada em vigor do Código Civil de 2002. Com a redução da maioridade civil, desaparece o dever de alimentos fundados no poder familiar, agora extinto aos dezoito e não mais aos vinte e um anos de idade (artigo $4^{\circ}$, inciso I, do Código Civil de 2002) ${ }^{385}$. Já decidiu nesse sentido o Ministro Sálvio de Figueiredo Teixeira, do Superior Tribunal de Justiça:

\footnotetext{
${ }^{385}$ Vale ser transcrita e endossada a ressalva de Mário Luiz Delgado, de que, mesmo com a extinção do poder familiar, o Juiz poderá negar o pedido formulado pelo alimentante caso os alimentos estejam fundados em causa outra, como, por exemplo, na relação de dependência com o alimentado. São as suas palavras: "Por outro lado, nada obsta que esse pedido de exoneração venha a ser rejeitado pelo Juiz de Família, com base nos mais diversos fundamentos. Pode-se argumentar que nos dias atuais a relação de dependência vem-se estendendo cada vez mais, e que 'na aplicação da lei, o juiz atenderá aos fins sociais a que ela se dirige e às exigências do bem comum' (LICC, art. $5^{\circ}$ ), o que justifica a manutenção do pensionamento, inclusive para além dos vinte e um anos, consoante já vinham decidindo os tribunais, nos casos de estudantes universitários. Ou seja, mesmo cessado o dever de sustento, persiste a obrigação alimentar se comprovado que os filhos não têm meios próprios de subsistência e necessitam de recursos para a educação". (in DELGADO, Mário Luiz. op. cit., p. 121).
} 
"O atingimento da maioridade civil representa a extinção do pátrio poder, ou, na linguagem do Novo Código Civil, poder familiar, a trazer como conseqüências para o alimentante o afastamento da sua obrigação de continuar prestando alimentos aos filhos, salvo exceções, devidamente comprovadas. Não comprovação por parte da agravada de que encontrase cursando nível superior, a importar na impossibilidade de continuar percebendo pensão alimentícia, ${ }^{\text {,386 }}$.

A conclusão tem respaldo no magistério de Carlos Francesco Gabba:

"A obrigação de prestar alimentos entre parentes de um certo grau é, verdadeiramente, um efeito deste grau, decorrente desta condição, e a lei que o assegura é lei de estado pessoal. Como tal, esta deve ser aplicada retroativamente [efeito imediato], isto é, a todas as pessoas que se encontrem na situação nela contemplada. $\mathrm{O}$ direito expectado de um parente de perceber os alimentos de um outro não gera direito adquirido, pois não se poderia falar em direito adquirido a uma condição pessoal $(\ldots)^{3,387}$.

Contudo, a lei nova não pode dispor sobre as faculdades já exercidas - não atingindo, por exemplo, a paternidade já reconhecida, os alimentos já prestados etc. Também não atinge deveres descumpridos no passado ou proibições que não tenham sido observadas antes de seu advento.

\subsubsection{Casamento entre colaterais - Código Civil de 2002 x Decreto-Lei $\mathrm{n}^{0}$ 3.200/41}

O artigo 183, inciso IV, do Código Civil de 1916, dispunha que "não podem casar (...) os colaterais, legítimos ou ilegítimos, até o terceiro grau inclusive”. Contudo, o Decreto-Lei $n^{\circ} 3.200 / 41$ excepcionava tal regra, admitindo o casamento entre colaterais de terceiro grau nos casos em que, por perícia médica, fosse constatado não haver prejuízo para a

\footnotetext{
${ }^{386}$ STJ, REsp n 65.691/SP, Rel. Min. Sálvio de Figueiredo Teixeira, j. 24.3.1997, v.u. Acórdão retirado da obra de Mário Luiz Delgado (Id. Ibid., p. 123).

${ }^{387}$ GABBA, Carlos Francesco. op. cit., v. 2, p. 247. Tradução livre de: “(...) L'obbligo degli alimenti fra parenti di un certo grado, è veramente un effetto di questo grado, attiene quindi strettamente allo stato personale, e la legge che lo risguarda à legge di stato personale. Come tale, essa devesi applicare retroattivamente, ciò̀ immediatamente a tutte le persone che trovansi nel caso da essa contemplato. D'altra parte il diritto spettante ad un parente di percepire gli alimenti da un altro parente per titolo di indigenza in caso contemplato dalla legge, non si può dire nè un effeto immediato, nè un effeto sostanziale dello stato di parente in quel dato grado, cosicchè non si può neppure attribuìre la natura di diritto acquisto di stato personale (...)".
} 
prole. Embora aparentemente conflitasse com o texto do Código Civil de 1916, o DecretoLei $\mathrm{n}^{\circ} 3.200 / 41$ prevalecia por se tratar de norma especial.

O artigo 1.521, inciso IV, do Código Civil de 2002, repetiu a regra do artigo 183, inciso IV, do Código Civil de 1916, dispondo que "não podem casar (...) colaterais, até o terceiro grau inclusive”. O artigo gerou a seguinte dúvida: o Código Civil de 2002 teria revogado o Decreto-Lei $n^{\circ} 3.200 / 41$, por ser norma posterior? A resposta é negativa, pois o Decreto-Lei no 3.200/41 é norma especial, cuja vigência não cessa pela superveniência da norma geral.

Vale dizer, o Decreto-Lei n ${ }^{\circ}$ 3.200/41 não excepcionava o Código Civil de 1916 por ser norma posterior, mas por ser norma especial; logo, o Decreto-Lei no 3.200/41 não deixa de excepcionar a regra do artigo 183, inciso IV, do Código Civil de 1916, em razão da superveniência do artigo 1.521, inciso IV, do Código Civil de 2002, de mesmo texto. Nesse sentido é o entendimento de Luiz Edson Fachin e Carlos Eduardo Pianovski Ruzyk:

"O Código Civil de 2002 não revoga o Decreto-lei n. 3200/41. Vale dizer, em primeiro lugar, que não há revogação expressa do diploma legal. Poderse-ia alegar, entretanto, como fundamento para a revogação, que a lei posterior revoga a anterior. Esse entendimento, todavia, afronta o princípio da especialidade. Com efeito, o Decreto-lei n. 3.200/41 é regra especial em relação ao Código Civil, pelo que sua disciplina se mantém íntegra" ${ }^{388}$.

A bem da verdade, a discussão não tem nenhuma razão de ser, tendo em vista que, ao repetir - apenas - o texto do Código Civil de 1916, o Código Civil de 2002 não gerou conflito de leis no tempo, demandando que a questão continue a ser decidida da mesma forma que já vinha sendo.

\subsubsection{As sociedades entre cônjuges constituídas antes do Código Civil de 2002 - os artigos 977 e 2.031}

O artigo 977 do Código Civil de 2002 proibiu os cônjuges de contratarem entre si sociedade se estiverem casados no regime da comunhão universal de bens ou no da separação

\footnotetext{
${ }^{388}$ in FACHIN, Luiz Edson; RUZYK, Carlos Eduardo Pianovski. Código Civil comentado. Coordenador Álvaro Villaça Azevedo. São Paulo: Atlas, 2003. v. 15, p. 64.
} 
obrigatória, procurando com isto evitar a ocorrência de fraudes empresariais. Dispõe o referido dispositivo:

“Artigo 977. Faculta-se aos cônjuges contratar sociedade, entre si ou com terceiros, desde que não tenham casado no regime da comunhão universal de bens, ou no da separação obrigatória".

Por sua vez, o artigo 2.031, caput, veio dispor que as sociedades que estivessem em desacordo com o Código Civil de 2002 deveriam se adaptar até 11 de janeiro de 2007. In verbis:

"Art. 2.031. As associações, sociedades e fundações, constituídas na forma das leis anteriores, bem como os empresários, deverão se adaptar às disposições deste Código até 11 de janeiro de 2007”389.

Ante tais estipulações, colocam-se três perguntas: (1) as sociedades entre cônjuges constituídas antes de 11 de janeiro de 2003 devem se adaptar ao Código Civil de 2002, conforme prescreve o artigo 2.031, ou os contratos sociais configuram ato jurídico perfeito, protegido contra o advento da lei nova? (2) os cônjuges casados antes de 11 de janeiro de 2003 poderão se furtar à aplicação do artigo 977 do Código Civil de 2002? (3) as pessoas sócias antes de 11 de janeiro de 2003 podem se casar no regime da comunhão total ou no da separação de bens?

As três perguntas são respondidas com a mesma fórmula: proibições e faculdades ainda não exercidas são disciplinadas pela lei vigente ao tempo de sua estatuição. Logo, o Código Civil de 2002 não poderia proibir a existência de sociedade já constituída; de igual maneira, sócios ou cônjuges casados antes do início de sua vigência não poderiam pretender se valer de faculdades da legislação pretérita.

Como o direito intertemporal brasileiro é informado pela regra do efeito imediato limitado à proteção do ato jurídico perfeito, do direito adquirido e da coisa julgada, o Código Civil de 2002 deve reger tão-somente - porém todas - as sociedades constituídas depois do início de sua vigência, não se voltando sobre os contratos sociais anteriores a 11

\footnotetext{
${ }^{389}$ Redação dada pela Lei $\mathrm{n}^{\mathrm{o}} 11.127 / 05$.
} 
de janeiro de 2003 nem permitindo que sócios ou cônjuges unidos antes dessa data possam se valer de regras já revogadas.

De fato, os contratos sociais das sociedades constituídas antes do Código Civil de 2002, por cônjuges casados nos regimes da comunhão total ou no da separação de bens, configuram ato jurídico perfeito, que está ao abrigo de proibições impostas pela lei nova é ato que, quando realizado, respeitou todas as formalidades que lhe eram impostas, exaurindo seus efeitos em um tempo passado. Por sua vez, as possibilidades de contratar entre si e de casar nos regimes da comunhão total ou no da separação de bens eram faculdades que, se não exercidas antes do Código Civil de 2002, pertenciam apenas ao direito objeto, e não poderiam, pois, ser reclamadas como direito adquirido dos sócios ou dos cônjuges unidos antes de 11 de janeiro de $2003^{390}$.

\subsection{Direito das Sucessões}

Sucessão indica que algo trocou de dono, passando de um sujeito a outro. De acordo com De Plácido e Silva, suceder exprime "uma relação de ordem, de continuidade, ou uma seqüência de fatos ou de coisas, define o que se segue, o que vem para colocar-se em lugar de qualquer outra coisa, ou o que vem em certa ordem, ou em certo tempo" ${ }^{, 391}$.

\footnotetext{
${ }^{390} \mathrm{Em}$ reforço, confira-se o entendimento de Marilene Silveira Guimarães: "A aplicabilidade desse dispositivo tem efeito imediato para todas as sociedades constituídas a contar de 11.01.2003, pois trata-se de norma material, cuja aplicabilidade só pode ser exigida a contar da data da vigência do novo Código, pelas mesmas razões referidas quanto à imediata aplicação da regra que autoriza a alteração do regime de bens.

As empresas já constituídas por cônjuges sócios não são atingidas pela nova regra do artigo 977. Porém, os empresários que já forem sócios entre si e desejarem casar, deverão fazê-lo por um dos regimes autorizados pelo artigo 997 (sic) (...)" (in GUIMARÃES, Marilene Silveira. Família e empresa: questões controvertidas. In: DELGADO, Mário Luiz; ALVES, Jones Figueiredo (Coords.). Questões controvertidas no novo Código Civil, cit., p. 303).

No mesmo sentido, Marcelo Fortes Barbosa Filho: “(...) As sociedades constituídas antes do início da vigência do novo Código não foram atingidas, dado o princípio da preservação do ato jurídico perfeito, inserido no art. $5^{\circ}$, XXXVI, da Constituição da República, como reconhecido pelo Departamento Nacional do Registro do Comércio (Parecer DNRC/Cojur n. 125/03), descartada, então, a necessidade de alteração do quadro social ou do regime de bens adotado (...)." (in BARBOSA FILHO, Marcelo Fortes. Código Civil comentado: doutrina e jurisprudência. Coord. Cezar Peluso. Barueri: Manole, 2007. p. 819).

${ }^{391}$ SILVA, De Plácido e. Vocabulário jurídico. 27. ed. rev. e atual. por Nagib Slaibi Filho e Gláucia Carvalho. Rio de Janeiro: Forense, 2008. p. 1.341.
} 
Quando há sucessão, o direito deixa de ser de uma pessoa e passa a ser de outra, ao que se denomina aquisição derivada de direitos ${ }^{392}$. Por exemplo, quando um filantropo doa a uma Organização Não-Governamental um terreno, a propriedade do imóvel sucede do benemérito para a instituição; quando se aluga um apartamento, o direito à posse direta do bem se transfere do locador para o locatário; quando determinada pessoa falece, seus bens são imediatamente transferidos a seus herdeiros, legítimos ou testamentários - em todos esses casos, os sucessores adquirem um direito que já fora de alguém, e daí se dizer aquisição derivada ou sucessão.

Embora não afete a existência do direito, a sucessão altera sua titularidade, fazendo com que seja adquirido para um o que era do domínio de outrem. Essa alteração se dá pela vontade das partes (por exemplo, na compra e venda, na locação e na sucessão testamentária) ou por força da lei, diretamente (e.g. no caso da sucessão legítima), e pode ocorrer por ato inter vivos ou causa mortis.

De toda forma, ambas as hipóteses pressupõem conformidade com o sistema jurídico vigente ao tempo da sucessão: no primeiro caso, de sucessão decorrente da vontade das partes, mister que a transferência esteja em conformidade com as regras e princípios existentes ao tempo da declaração de vontade. Assim, por exemplo, a compra e venda, o aluguel e a forma do testamento deverão observar os requisitos impostos pela lei e pelos princípios do tempo em que foram celebrados; no segundo caso, de sucessão decorrente diretamente da lei, só será sucessor aquele a que a lei contemplar ao tempo da sucessão. Assim, por exemplo, a qualidade de herdeiro será aferida no momento da morte do autor da herança.

No direito das sucessões, a palavra sucessão é empregada exclusivamente para designar a aquisição derivada de direitos por ato causa mortis. Esclarece Carlos Roberto Gonçalves que "no direito das sucessões, o vocábulo é empregado em sentido estrito, para designar tão-somente a decorrente da morte de alguém, ou seja, a sucessão causa mortis" ${ }^{393}$.

\footnotetext{
${ }^{392}$ Conforme afirma Sílvio de Salvo Venosa: "Sempre que houver aquisição derivada de direitos, estaremos diante do que se denomina sucessão" (in VENOSA, Sílvio de Salvo. Direito civil: parte geral. 2. ed. São Paulo: Atlas, 2002. v. 1, p. 360).

${ }^{393}$ GONÇALVES, Carlos Roberto. Direito civil brasileiro: direito das sucessões. São Paulo: Saraiva, 2007. v. 7, p. 1-2.
} 
Já o direito intertemporal, nesta seara, tem por finalidade definir qual a lei aplicável à sucessão causa mortis, legítima ou testamentária, o que na maioria dos casos pode ser resolvido pela regra constante do artigo 1.787 do Código Civil ${ }^{394}$ :

"Art. 1.787. Regula a sucessão e a legitimação para suceder a lei vigente ao tempo da abertura daquela".

Tal regra decorre do princípio da saisine, assentado no artigo 1.784 do Código Civil $^{395}$, segundo o qual "aberta a sucessão, a herança transmite-se, desde logo, aos herdeiros legítimos e testamentários". O princípio da saisine impede que, com a extinção da personalidade, os bens e direitos do de cujus pairem pelo ordenamento sem um sujeito, deferindo a herança aos herdeiros desde o momento da morte - obviamente, desde que estes tenham qualidade de herdeiros no momento do falecimento do autor da herança.

Por esta razão, não podem reclamar a herança aqueles que adquiriram a qualidade de herdeiro posteriormente à morte do de cujus, por mais que a herança ainda não houvesse sido aceita ou que não se tivesse proferido sentença decidindo a partilha - a aceitação apenas torna definitiva a transmissão da herança (artigo 1.804 do Código Civil), enquanto a sentença que decide a partilha somente declara a quota hereditária, possuindo - ambas - efeito retroativo à data da morte do autor da herança.

Conjugando-se o princípio da saisine com a regra do efeito imediato, conclui-se que a lei nova, posterior à morte, não poderia regular a transmissão dos bens do de cujus, atribuindo a determinada pessoa qualidade de herdeiro que não possuía ao tempo do falecimento. Como a herança se transmite com o falecimento, a lei nova estaria dispondo para trás, desautorizadamente, atribuindo conseqüências a hipótese anterior ao início de sua vigência. Nisso repousa a regra do artigo 1.787 do Código Civil, retro transcrito, e também a disposição transitória contida no artigo 2.041 do Código Civil. In verbis:

“Art. 2.041. As disposições deste Código relativas à ordem de vocação hereditária (arts. 1.829 a 1.844) não se aplicam à sucessão aberta antes de sua vigência, prevalecendo o disposto na lei anterior (Lei 3.071, de $1^{\circ}$ de janeiro de 1916)".

\footnotetext{
${ }^{394}$ Artigo 1.573 do Código Civil de 1916.

${ }^{395}$ Artigo 1.572 do Código Civil de 1916.
} 
A esse respeito é elucidativa a lição de Washington de Barros Monteiro:

\begin{abstract}
"Do disposto no citado art. 1.784 decorre que, aberta a sucessão, a herança se transmite imediatamente aos herdeiros, que se tornam, assim, titulares de direitos adquiridos. Tal situação, definitivamente constituída, não pode ser afetada ou comprometida por fato novo, ou por lei nova, ex vi do estatuído no art. $5^{\circ}$, n. XXXVI, da Constituição Federal de 1988 e no art. 2.041 do Código Civil de 2002. Em matéria de vocação hereditária não se legisla para alcançar o passado, mas apenas para reger o futuro. A lei do dia da morte rege todo o direito sucessório, quer se trate de fixar a vocação hereditária, quer de determinar a extensão da quota hereditária. Não pode a lei nova disciplinar sucessão aberta na vigência da lei anterior" ${ }^{\text {"396 }}$.
\end{abstract}

A sucessão opera, para o herdeiro ou legatário, a aquisição de um direito de aquisição simples (item 3.3.1), o qual deverá ser regulado, em seu todo, pela lei do tempo da aquisição - aquisição que se dá, conforme exposto, com a morte do autor da herança. Com base nesta regra deverão ser resolvidos os problemas práticos referentes ao conflito de leis no tempo, alguns dos quais serão abordados nos tópicos seguintes.

\title{
5.7.1. A alteração da ordem de vocação hereditária pelo Código Civil de 2002
}

À falta de disposição de última vontade, em testamento, a herança é deferida em uma ordem de preferência preestabelecida em lei, pela qual os herdeiros mais próximos excluem os mais remotos, conforme sejam chamados a suceder.

De acordo com a regra enunciada no item anterior, a herança deve ser deferida segundo a ordem de vocação hereditária existente ao tempo da abertura da sucessão, não podendo lei posterior conferir a alguém qualidade de herdeiro que não possuía ao tempo da morte do de cujus, nem retirar-lhe. Nesse sentido dispõem os artigos 1.787 e 2.041, retro citados.

Assim não fosse, permitir-se-iam abusos e desmandos como os da sucessão de Paul Deleuse, cuja herança foi considerada jacente, pelo Governo Vargas do Estado Novo, embora existisse parente sucessível ao tempo da abertura da sucessão. Esse caso está relatado à frente, no item 5.7.4.

\footnotetext{
${ }^{396}$ MONTEIRO, Washington de Barros. Curso de direito civil: direito das sucessões. 35. ed., rev. e atual. por Ana Cristina de Barros Monteiro França Pinto de acordo com o Novo Código Civil (Lei n. 10.406, de 10.1.2002). São Paulo: Saraiva, 2003. p. 18.
} 
Por essa razão, só se aplica a ordem de vocação hereditária constante do artigo 1.829 do Código $\mathrm{Civil}^{397}$ às sucessões abertas depois de 11 de janeiro de 2003. Às sucessões abertas antes dessa data, aplicam-se as disposições constantes do artigo 1.603 do Código Civil de $1916^{398}$. Por exemplo, o cônjuge só irá concorrer com os ascendentes e descendentes neste caso, a depender do regime de bens - se o de cujus houver falecido antes do início da vigência do Código Civil de 2002.

\subsubsection{A sucessão do companheiro: o choque entre o Código Civil de 1916, as Leis no 8.791/94 e 9.278/96 e o Código Civil de 2002}

O Código Civil de 1916 não reconhecia a união estável nem conferia direitos sucessórios ao companheiro supérstite. No regime de 1916, morto o companheiro, deferia-se a herança aos descendentes (artigo 1.603 do Código Civil de 1916); na falta destes, chamavam-se os ascendentes (artigo 1.606 do Código Civil de 1916); não havendo descendentes ou ascendentes, deferia-se a sucessão ao cônjuge sobrevivente (artigo 1.611 do Código Civil de 1916) e, na falta deste, sucediam os colaterais, até o quarto grau (artigo 1.612 do Código Civil de 1916).

Os então denominados concubinos gozavam apenas do direito à partilha proporcional dos bens adquiridos em esforço comum, o que era reconhecido pela Súmula $\mathrm{n}^{\circ} 380$ do STF, a dispor que, "comprovada a sociedade de fato entre os concubinos, é cabível a sua dissolução judicial, com a partilha do patrimônio pelo esforço comum”.

Com a Constituição Federal de 1988, a união estável passa a ser reconhecida como entidade familiar, dispondo o artigo 226, $\S 3^{\circ}$, que, "para efeito da proteção do Estado, é

\footnotetext{
${ }^{397}$ Art. 1.829: “A sucessão legítima defere-se na ordem seguinte:

I-aos descendentes, em concorrência com o cônjuge sobrevivente, salvo se casado este com o falecido no regime da comunhão universal, ou no da separação obrigatória de bens (art. 1.640, parágrafo único); ou se, no regime da comunhão parcial, o autor da herança não houver deixado bens particulares;

II-aos ascendentes, em concorrência com o cônjuge;

III-ao cônjuge sobrevivente;

IV-aos colaterais".

${ }^{398}$ Art. 1.603 do Código Civil de 1916: “A sucessão legítima defere-se na ordem seguinte:

I-aos descendentes;

II-aos ascendentes;

III-ao cônjuge sobrevivente;

IV-aos colaterais;

V-aos Municípios, ao Distrito Federal ou à União".
} 
reconhecida a união estável entre o homem e a mulher como entidade familiar, devendo a lei facilitar sua conversão em casamento". Já o direito sucessório do companheiro vai ser regulamentado pela Lei $\mathrm{n}^{\mathrm{o}} 8.971 / 94$, que lhe conferiu o direito de herdar a totalidade da herança caso não houvesse descendentes ou ascendentes (artigo $2^{\circ}$, inciso III), percebendo usufruto vidual no caso de existência destes (artigo $2^{\circ}$, incisos I e II).

Posteriormente, em adição à Lei no 8.971/94, a Lei nº 9.278/96 conferiu ao companheiro sobrevivente direito real de habitação, enquanto este vivesse e não constituísse nova união estável ou casamento (artigo $7^{\circ}$, parágrafo único). Até então, portanto, estava-se a conferir ao companheiro supérstite o direito de herdar a totalidade da herança ou de gozar do usufruto vidual, conforme existissem ou não descendentes ou ascendentes, mais o direito real de habitação - direitos esses que superavam os que o Código Civil de 1916 conferia ao cônjuge sobrevivente.

Por sua vez, o Código Civil de 2002 deu novo tratamento à matéria, conferindo ao companheiro supérstite o direito de herdar os bens adquiridos onerosamente na vigência da união estável, em concorrência com os descendentes do de cujus (comuns ou não) ou com qualquer outro parente sucessível. Dispõe o artigo 1.790:

\footnotetext{
"Art. 1.790. A companheira ou o companheiro participará da sucessão do outro, quanto aos bens adquiridos onerosamente na vigência da união estável, nas condições seguintes:

I - se concorrer com filhos comuns, terá direito a uma quota equivalente à que por lei for atribuída ao filho;

II - se concorrer com descendentes só do autor da herança, tocar-lhe-á a metade do que couber a cada um daqueles;

III - se concorrer com outros parentes sucessíveis, terá direito a 1/3 (um terço) da herança;

IV - não havendo parentes sucessíveis, terá direito à totalidade da herança."
}

Como se infere desse dispositivo, o companheiro supérstite não participará na sucessão dos bens particulares do de cujus. Quanto aos bens adquiridos pelo esforço comum, o companheiro sobrevivente fará jus à meação e a uma quota da metade deixada pelo autor da 
herança, nas seguintes proporções: se concorrer com descendentes ${ }^{399}$ comuns do de cujus, receberá, além da meação, quota igual à que couber a cada descendente (por exemplo, se o de cujus tiver deixado dois filhos comuns, o companheiro sobrevivente perceberá 1/3 da herança adquirida pelo esforço comum, mais a meação); se concorrer com descendentes unilaterais do de cujus, receberá, em adição à meação, quota equivalente à metade da que couber a cada descendente (exemplo: se o de cujus tiver deixado dois filhos unilaterais, o companheiro sobrevivente perceberá $1 / 5$ da herança construída onerosamente na constância da união estável, mais a meação); se concorrer com outros parentes sucessíveis - ascendentes e colaterais até o quarto grau -, o companheiro sobrevivente fará jus à meação mais $1 / 3$ sobre a metade dos bens adquiridos onerosamente na constância da união estável.

Se o autor da herança tiver deixado descendentes comuns e unilaterais - o Código Civil de 2002 é omisso - dever-se-á estabelecer a quota do companheiro sobrevivente por meio de uma média ponderada, obtida pela soma do número de descendentes comuns, multiplicados por um, mais o número de descendentes unilaterais, multiplicados por meio, dividida pelo número total de filhos (por exemplo, se o autor da herança tiver deixado quatro descendentes, dos quais dois comuns e dois unilaterais, o companheiro supérstite deverá receber 3/4 da quota reservada a cada descendente, ou seja, $75 \%$ do que receberá cada um) $)^{400}$.

Caso o autor da herança não tenha deixado outros parentes sucessíveis, a herança deverá ser deferida em sua totalidade ao companheiro supérstite ${ }^{401}$. Embora, a rigor, o inciso IV devesse fazer remissão ao caput do artigo 1.790 - que trata apenas dos bens adquiridos onerosamente na constância da união estável, excluindo os bens particulares do companheiro morto -, esta interpretação seria incoerente com o artigo 1.844, segundo o qual a herança só será

\footnotetext{
${ }^{399}$ Embora o artigo 1.790, inciso I, refira-se a "filho", uma interpretação sistemática - confrontada com o inciso II do citado dispositivo -, recomenda entender-se "descendente", sejam filhos ou não (netos, por exemplo). A esse respeito, comenta Carlos Roberto Gonçalves: "Observa-se ter havido equívoco do legislador no emprego da palavra 'filho', quando a finalidade precípua da norma é regular a concorrência do companheiro com os 'descendentes'. Tanto assim que no inciso II foi corretamente empregada esta última palavra. Desse modo, mediante uma interpretação extensiva e sistemática, torna-se possível compatibilizar a norma do inciso I do art. 1.790 com o inciso II do mesmo dispositivo, que se refere corretamente a 'descendentes"'. (in GONÇALVES, Carlos Roberto. Direito civil brasileiro: direito das sucessões, cit., p. 174).

${ }^{400} \mathrm{O}$ tema é bastante controverso, havendo quem sustente que a quota do companheiro supérstite seria igual à daquele que concorre com descendentes comuns. Por sua vez, outros sustentam que, existindo descendentes comuns e unilaterais, a quota do companheiro sobrevivente seria igual à daquele que concorre com descendentes comuns (a esse respeito, Mauro Antonini - in ANTONINI, Mauro. Código Civil comentado: doutrina e jurisprudência. Coord. Cezar Peluso. Barueri: Manole, 2007. p. 1.782).

${ }^{401}$ Nesse sentido é o entendimento de Mauro Antonini (in ANTONINI, Mauro. op. cit., p. 1.784). Em sentido contrário, confira-se o entendimento de Silvio Rodrigues (in RODRIGUES, Silvio. Direito civil: direito das sucessões. 25. ed. atual. por Zeno Veloso; de acordo com o novo Código Civil (Lei n. 10.406, de 10-12002). São Paulo: Saraiva, 2002. p. 117-118).
} 
considerada jacente "não sobrevivendo cônjuge, ou companheiro, nem parente algum sucessível, ou tendo eles renunciado a herança (sic)". Comentam Nelson Nery Junior e Rosa Maria de Andrade Nery:

"Não está claro na lei como se dá a sucessão dos bens adquiridos a título gratuito pelo falecido na hipótese de ele não ter deixado parentes sucessíveis. O CC 1790 caput, sob cujos limites os incisos que se lhe seguem devem ser interpretados, somente confere direito de sucessão ao companheiro com relação aos bens adquiridos onerosamente na vigência da união estável, nada dispondo sobre os bens adquiridos gratuitamente durante esse mesmo período. É de se indagar se, em face da limitação do CC 1790 caput, o legislador ordinário quis excluir o companheiro na sucessão desses bens, fazendo com que a sucessão deles fosse deferida à Fazenda. Parece-nos que não, por três motivos: a) o CC 1844 manda que a herança seja devolvida ao ente público, apenas na hipótese de o de cujus não ter deixado cônjuge, companheiro ou parente sucessível; b) quando o companheiro não concorre com parente sucessível, a lei se apressa em mencionar que o companheiro terá direito à totalidade da herança (CC 1790 IV), fugindo do comando do caput, ainda que sem muita técnica legislativa; c) a abertura da herança jacente dá-se quando não há herdeiro legítimo (CC 1819) e, apesar de não constar do rol do CC 1829, a qualidade sucessória do companheiro é de sucessor legítimo e não de testamentário"402.

No que toca ao direito real de habitação, o Código Civil de 2002 foi silente quanto ao companheiro, deferindo-o apenas ao cônjuge supérstite (artigo 1.831 do Código Civil).

Como se vê, o Código Civil de 2002 introduziu profunda modificação nos direitos sucessórios do companheiro sobrevivente, por vezes rebaixando-o a situação extremamente inferior à do cônjuge supérstite. A esse respeito, comenta Silvio Rodrigues:

“(...) ao regular o direito sucessório entre os companheiros, em vez de fazer as adaptações e consertos que a doutrina já propugnava, especialmente nos pontos em que o companheiro sobrevivente ficava numa situação mais vantajosa do que a viúva ou o viúvo, o Código Civil coloca os partícipes de união estável, na sucessão hereditária, numa posição de extrema inferioridade, comparada com o novo status sucessório do cônjuges" ${ }^{, 403}$.

Tais modificações suscitaram acaloradas discussões acerca de qual diploma - o Código Civil de 1916, as Leis nº 8.791/94 e 9.278/96 ou o Código Civil de 2002 - deveria ser aplicado

\footnotetext{
${ }^{402}$ in NERY JUNIOR, Nelson; NERY, Rosa Maria de Andrade. Novo Código Civil e Legislação Extravagante anotados. 1. ed. São Paulo: Ed. Revista dos Tribunais, 2002. p. 600.

${ }^{403}$ in RODRIGUES, Silvio. Direito civil: direito das sucessões, cit., p. 117.
} 
à sucessão dos companheiros unidos antes de 2003. A controvérsia foi acirrada pela alegação de que o novel artigo 1.790 seria inconstitucional, por estabelecer diferenciação entre o casamento e a união estável ${ }^{404}$.

No que toca ao objeto deste trabalho, impõem-se as seguintes questões: (1) qual a lei aplicável às uniões estáveis iniciadas durante os regimes anteriores ao Código Civil de 2002? (2) o Código Civil de 2002 extinguiu o direito real de habitação do companheiro sobrevivente? (3) qual o regime aplicável à sucessão dos companheiros para aqueles que entendem pela inconstitucionalidade do artigo 1.790 do Código Civil de 2002? Tais questões estão respondidas nos itens que seguem.

\subsubsection{A lei aplicável às uniões estáveis iniciadas nos regimes anteriores ao Código Civil de 2002}

A resposta para esta primeira questão repousa na regra seguinte: aplica-se à sucessão do companheiro a lei vigente ao tempo da morte do autor da herança, não importando quando se tenha iniciado a união estável. Importa apenas que os companheiros vivessem em união estável de acordo com a lei vigente ao tempo da abertura da sucessão.

Ou seja: até o advento da Lei $n^{\circ} 8.971 / 94$, o companheiro nada herdaria; a partir da Lei ${ }^{\circ}$ 8.971/94 e até a Lei n ${ }^{\circ}$ 9.278/96, o companheiro herdaria, de acordo com os ditames da Lei $n^{\circ} 8.971 / 94$, se, ao tempo da abertura da sucessão, preenchesse os requisitos impostos pelo artigo $1^{\circ}$ da referida lei ${ }^{405}$; da Lei $n^{\circ} 9.278 / 96$ até o início da vigência do Código Civil de 2002, o companheiro herdaria, de acordo com a Lei $n^{\circ}$ 9.278/96, se, quando morto o de cujus, estivessem presentes as condições previstas nesta norma, artigo $1^{\circ}$, para configuração

\footnotetext{
${ }^{404}$ Nesse sentido, ANTONINI, Mauro. op. cit., p. 1.779-1.782.

${ }^{405}$ Artigo $1^{\circ}$ da Lei $n^{\circ} 8.971 / 94:$ "A companheira comprovada de um homem solteiro, separado judicialmente, divorciado ou viúvo, que com ele viva há mais de 5 (cinco) anos, ou dele tenha prole, poderá valer-se do disposto na Lei 5.478 , de 25 de julho de 1968 , enquanto não constituir nova união e desde que prove a necessidade.

Parágrafo único. Igual direito e nas mesmas condições é reconhecido ao companheiro de mulher solteira, separada judicialmente, divorciada ou viúva".
} 
da união estável ${ }^{406}$; do início da vigência do Código Civil de 2002 em diante, o companheiro herdará, de acordo com o disposto no artigo 1.790, se preencher os requisitos do artigo $1.723^{407}$.

Por exemplo, até o advento da Lei ${ }^{\circ}$ 8.971/94, a companheira não podia se habilitar como herdeira em detrimento do sobrinho do de cujus. Isto o que decidiu o Superior Tribunal de Justiça, em voto relatado pelo Ministro Antônio de Pádua Ribeiro:

"Direito civil. Sucessão. Companheira. Sobrinhos do de cujus. Lei aplicável.

I. - No direito das sucessões aplica-se a lei vigente ao tempo da abertura da sucessão. Antes da Lei no 8.971, de 29/12/1994, a companheira não podia se habilitar como herdeira em detrimento de sobrinhos do de cujus $^{408,}$.

Não será possível aplicar simultaneamente o Código Civil de 2002 e as Leis nº 8.791/94 e 9.278/96 - e.g. conferindo-se ao companheiro supérstite o direito real de habitação previsto na Lei $\mathrm{n}^{\circ}$ 9.278/96. A despeito de algumas fortes e respeitáveis vozes em contrário, o Código Civil de 2002 revogou globalmente as Leis $n^{\circ}$ 8.791/94 e 9.278/96, ao dispor inteiramente sobre a matéria tratada naqueles diplomas legais. O ponto será objeto de estudo no item seguinte.

\subsubsection{A questão do direito real de habitação do companheiro no Código Civil de 2002}

O Código Civil de 2002 não repetiu a regra constante do artigo $7^{\circ}$ da Lei $n^{\circ}$ 9.278/96, conferindo direito real de habitação apenas ao cônjuge supérstite (artigo 1.831), sem nada dizer a respeito do direito real de habitação do companheiro sobrevivente - donde a pergunta: o companheiro sobrevivente faz jus a direito real de habitação? Para responder a esta questão, é necessário analisar se o Código Civil de 2002 revogou o artigo $7^{\circ}$, parágrafo único, da Lei $\mathrm{n}^{\circ} 9.278 / 96$, e se seria possível aplicar o artigo 1.831 aos companheiros, por analogia.

\footnotetext{
${ }^{406}$ Artigo $1^{\text {o }}$ da Lei no 9.278/96: "É reconhecida como entidade familiar a convivência duradoura, pública e contínua, de um homem e uma mulher, estabelecida com o objetivo de constituição de família".

${ }^{407}$ Artigo 1.723 do Código Civil: "É reconhecida como entidade familiar a união estável entre o homem e a mulher, configurada na convivência pública, contínua e duradoura e estabelecida com o objetivo de constituição de família.

$\S 1^{\circ}$.A união estável não se constituirá se ocorrerem os impedimentos do art. 1.521; não se aplicando a incidência do inciso VI no caso de a pessoa casada se achar separada de fato ou judicialmente.

$\S 2^{\circ}$.As causas suspensivas do art. 1.523 não impedirão a caracterização da união estável".

${ }^{408}$ STJ, $3^{\text {a }}$ Turma, REsp n ${ }^{\circ}$ 205517/SP, Rel. Min. Antônio de Pádua Ribeiro, j. 19.5.2003, v.u.
} 
Doutrina e jurisprudência divergem quanto à revogação do artigo $7^{\circ}$ da Lei $n^{\circ}$ 9.278/96 pelo Código Civil de 2002. Argumentando não ter havido revogação, uma primeira corrente sustenta que o artigo $7^{\circ}$, parágrafo único, da Lei $n^{\circ} 9.278 / 96$, não seria incompatível com o Código Civil de 2002, razão pela qual não teria revogado expressa ou tacitamente aquele dispositivo. Nesse sentido é o Enunciado n ${ }^{\circ} 117$ do Conselho de Justiça Federal, aprovado na Primeira Jornada de Direito Civil:

"O direito real de habitação deve ser estendido ao companheiro, seja por não
ter sido revogada a previsão da Lei n. $9.278 / 96$, seja em razão da interpretação
analógica do art. 1.831, informado pelo art. $6^{\circ}$, caput, da CF/88".

No mesmo sentido vêm-se julgados dos Tribunais estaduais, como se infere das decisões abaixo, conduzidas pelos Desembargadores Rui Portanova, do Tribunal de Justiça do Rio Grande do Sul, e Encinas Manfré, do Tribunal de Justiça de São Paulo:

"RECONHECIMENTO. Apesar de o Código Civil não ter conferido
expressamente o direito real de habitação àqueles que viveram em união
estável, tal direito subsiste no ordenamento jurídico em razão do
parágrafo único do art. $7^{\circ}$ da Lei $9.278 / 96$. Inexiste incompatibilidade
entre essa Lei e o Código Civil em vigor. A equiparação entre união
estável e casamento foi levada a efeito pela Constituição Federal. Caso em
que se reconhece o direito real de habitação à companheira, considerando
a verossimilhança na alegação de que ela conviveu com o de cujus por
mais de 20 anos, pelo fato dela atualmente estar morando de favor e por
ser o imóvel que serviu de morada ao casal o único dessa espécie a
inventariar" 4 .

"INVENTÁRIO - Decisão pela qual se reconheceu direito real de habitação, à concorrência com os herdeiros na herança em relação ao bem imóvel e à meação a respeito de veículo adquirido na constância da união estável em favor de companheira do "de cujus" - Admissibilidade em parte Recorrida que não faz jus à meação no apontado imóvel - Submissão ao regime de separação obrigatória de bens em razão da idade de ambos - A propósito, bem particular do companheiro, pois adquirido antes dessa união - Direito a meação no que tange a veículo - Aplicação da Súmula 377 do Supremo Tribunal Federal - Reconhecimento ainda de direito real de habitação em favor dessa companheira - Inteligência dos artigos $7^{\circ}$, parágrafo único, da Lei 9.278/1996, 1.831 do Código Civil e 6º 'caput', da Constituição da República - Não revogação expressa dessa precedente lei ordinária pelo Código Civil vigente - Ademais, inexistência de incompatibilidade de normas - Recurso parcialmente provido" ${ }^{\text {"410 }}$.

${ }^{409}$ TJ/RS, 8 a Câm. Cív, AI n o 70019892595, Rel. Des. Rui Portanova, j. 29/05/2007, decisão monocrática.

${ }^{410}$ TJ/SP, 6 ${ }^{\text {a }}$ Câm. Dir. Priv., AI n ${ }^{\circ}$ 5301974200, Rel. Des. Encinas Manfré, j. 29.11.2007, votação por maioria, vencido o Desembargador Vito Guglielmi, que entendia pela inconstitucionalidade do artigo 1.790 do Código Civil, decidindo pela aplicação, ao companheiro sobrevivente, do mesmo tratamento conferido ao cônjuge supérstite. 
De fato, não se está diante de revogação expressa ou tácita. Contudo, a revogação da lei não se dá apenas de forma expressa (no texto) ou tácita (por incompatibilidade entre o novo texto e o da lei anterior). Mesmo que compatível com a lei antiga, a lei nova revogará a anterior quando regular inteiramente a matéria, ao que se chama revogação global. Isto o que consta do artigo $2^{\circ}, \S 1^{\circ}$, da Lei de Introdução ao Código Civil, in verbis:

Art. $2^{\circ}$. "Não se destinando à vigência temporária, a lei terá vigor até que outra a modifique ou a revogue.

$\S 1^{\circ}$. A lei posterior revoga a anterior quando expressamente o declare, quando seja com ela incompatível ou quando regule inteiramente a matéria de que tratava a lei anterior" (grifo não constante do original).

O Código Civil de 2002 somente não revogou globalmente "as disposições de natureza processual, administrativa ou penal, constantes de leis cujos preceitos de natureza civil hajam sido incorporados por este Código", conforme disposto no artigo 2.043.

Percebe-se, assim, que, ao tratar inteiramente da matéria, o Código Civil de 2002 revogou globalmente a Lei $n^{\circ} 9.278 / 96$, pondo fim a todas as disposições que não hajam sido repetidas pela nova lei civil. Vale dizer, o Código Civil de 2002 deu novo tratamento a toda a matéria, e não apenas aos artigos que com ele fossem incompatíveis. Daí não se poder dizer que o artigo $7^{\circ}$, parágrafo único, da Lei $n^{\circ}$ 9.278/96 - que trata do direito real de habitação -, tenha continuado a viger "por não ser incompatível com o Código Civil de 2002" 411.

\footnotetext{
${ }^{411}$ No mesmo sentido, o entendimento de Zeno Veloso: “(...) o novo Código Civil não conferiu nem admite que se confira direito real de habitação ao companheiro. Não há que se falar em sobrevivência do art. 7. parágrafo único, da Lei 9.278, nem, muito menos, das normas da Lei 8.971/94. O novo Código regulou inteiramente a matéria relativa à sucessão entre companheiros, não deixando margem para qualquer dúvida ou entredúvida. Não houve revogação expressa, é verdade! Mas a revogação expressa não é a única forma de revogação que existe. Por ter regulado inteiramente o assunto, o Código Civil revogou tacitamente - e inexoravelmente - as duas aludidas leis, que tratavam da sucessão entre companheiros" (in VELOSO, Zeno. Direito real de habitação na união estável. In: DELGADO, Mário Luiz; ALVES, Jones Figueiredo (Coords.). Questões controvertidas no novo Código Civil. São Paulo: Método, 2003. p. 413-414). Em sentido contrário, o entendimento de Miguel Reale: "Observo, todavia, que, nessa matéria, o novo Código Civil não revogou, por ser lei posterior, as Leis 8.971, de 29 de dezembro de 1994, e 278, de 10 de maio de 1996, ocorrendo um caso típico de vigência concomitante a que acima me refiro" (in REALE, Miguel. Estudos preliminares do Código Civil. São Paulo: Ed. Revista dos Tribunais, 2003. p. 73); e de Giselda Maria Fernandes Noavaes Hironaka: "Não estabelece o Código Civil atual o direito real de habitação previsto pela lei 9.278/96, devendo-se, por isso, e em analogia com a situação garantida ao cônjuge e autorizada pela Constituição Federal, ter o dispositivo do art. 7. ${ }^{\circ}$, parágrafo único, desta lei como não revogado" (in HIRONAKA, Giselda Maria Fernandes Novaes. Concorrência do companheiro e do cônjuge na sucessão dos descendentes. In: DELGADO, Mário Luiz; ALVES, Jones Figueiredo (Coords.). Questões controvertidas no novo Código Civil. São Paulo: Método, 2003. v. 1, p. 427).
} 
Resta saber se se poderia conferir direito real de habitação ao companheiro supérstite por interpretação analógica do artigo 1.831 do Código Civil. Para que isso fosse possível, seria necessário reconhecer a existência de lacuna no Código Civil de 2002, o que pressuporia uma omissão despropositada do Legislador (artigo $4^{\circ}$ da Lei de Introdução ao Código Civil). Excelentes juristas entendem assim, sendo nesse sentido o Enunciado $\mathrm{n}^{\mathrm{o}} 117$ do Conselho de Justiça Federal, retro transcrito, e julgados dos Tribunais de Justiça dos Estados, pelos quais fala a decisão do Desembargador Paulo Dias de Moura Ribeiro, do Tribunal de Justiça do Estado de São Paulo:

"Parece possível antever neste instante processual que o agravante pode ter tido com a finada uma vida de companheirismo aberto e isso poderá lhe gerar o direito real de habitação pela adequada interpretação do art. 1.831 , do CC/02"412.

Contudo, tudo indica que - de forma injusta, é verdade - o Legislador quis deixar de conferir direito real de habitação ao companheiro sobrevivente. Com perdão pelo trocadilho, o silêncio falou pelo Legislador, razão pela qual não poderia o intérprete integrá-lo por meio de dispositivo pretensamente análogo. Houve silêncio eloqüente e não lacuna da lei. Conforme sustenta Zeno Veloso:

"O silêncio eloqüente é situação diversa, inconfundível. O legislador não mencionou ou não previu dada situação porque, consciente $e$ deliberadamente, não quis fazê-lo, não admitia a hipótese, repele-a, rejeitaa, e a falta de menção é o sinal inequívoco desse propósito de cortar, excluir, suprimir. Se se trata não de lacuna, mas de silêncio eloqüente da lei, o intérprete ou o julgador não pode preencher o vazio, recorrer à analogia, superar a deficiência, suprir a incompletude, pois, simplesmente, não há vazio, não há omissão que deva ser composta ou resolvida, e, ao contrário, no silêncio da norma há um comando, uma afirmação, um preceito. $\mathrm{O}$ que se não disse não deixou de ser dito por falha, erronia, olvido, mas porque não se quis dizer, efetivamente, excluindo-se da regra jurídica o que não se disse. A restrição é intencional. Daí a expressão beredtes Scheweigen $=$ silêncio eloqüente (...).

Frente ao tenebroso art. 1.790, com suas extremas restrições e limitações, e analisando o Código Civil sistematicamente, não há como fugir da conclusão de que o legislador de 2002 quis modificar radicalmente a situação anterior, constrangendo e reduzindo o direito sucessório dos que viveram em união estável. Não é uma boa lei; temos que muda-la, já e já! Por enquanto, todavia, habemus legem, e o intérprete não pode se travestir de legislador, tomar o lugar do Parlamento, e modificar a lei, por sua conta.

${ }^{412}$ TJ/SP, $11^{\text {a }}$ Câm. Dir. Priv., AI no 7.211.866-6, Rel. Des. Paulo Dias de Moura Ribeiro, j. 2.4.2008, v.u. 
Direito real de habitação com relação ao imóvel residencial, para o companheiro sobrevivente, no estágio atual do direito brasileiro, não existe mais" $" 413$.

Uma interpretação sistemática comprova que, quando pretendeu conferir direitos ao companheiro sobrevivente, o Legislador o fez expressamente - o que poderia ter feito em relação ao direito real de habitação, se o quisesse. É preciso observar que, também quanto a outros aspectos, o Legislador houve por bem submeter o companheiro sobrevivente a situação de extrema inferioridade em relação ao cônjuge supérstite - o que se nos afigura uma injustiça, repita-se, mas a ser corrigida de lege ferenda, e não por meio da analogia.

Em parecer enviado à Comissão Especial do Código Civil, na Câmara dos Deputados, o Deputado Ricardo Fiuza afirma ter sido intenção do Legislador conferir tratamento diferenciado a cônjuges e companheiros no que toca aos aspectos sucessórios. Argumenta que a união estável é uma instituição-meio e não poderia, pois, receber o mesmo tratamento dispensado ao casamento, o qual constitui uma instituição-fim. Este o trecho final do parecer:

\footnotetext{
"As diretrizes imprimidas à elaboração do Projeto, fiéis nesse ponto às regras constitucionais e legais vigorantes, aconselham ou, melhor dizendo, impõem um tratamento diversificado, no plano sucessório, das figuras do cônjuge supérstite e do companheiro sobrevivo, notadamente se ocorrer qualquer superposição ou confusão de direitos à sucessão aberta. Impossibilitado que seja um tratamento igualitário, inclusive por descaracterizar tanto a união estável - enquanto instituição-meio - quanto o casamento - enquanto instituição-fim -, na conformidade do preceito constitucional. A natureza tutelar da união estável constitui, na verdade, uma parcial correção da desigualdade reconhecida no plano social e familiar, desde que atentemos ser o casamento mais estável do que a estabilidade da convivência duradoura. Nulidades, anulabilidades, separação e divórcio, figuras indissoluvelmente ligadas ao enlace matrimonial, desaparecem, ou transparecem por analogia, ou se reduzem numericamente, quando transpostas para o relacionamento estável.

Tomamos assim como diretrizes básicas, na caracterização dos direitos sucessórios do cônjuge e do convivente, a prevalência da relação matrimonial em confronto com o relacionamento estável" ${ }^{\text {"414 }}$.
}

\footnotetext{
${ }^{413}$ in VELOSO, Zeno. op. cit., p. 414.

${ }^{414}$ in REALE, Miguel. História do novo Código Civil. São Paulo: Ed. Revista dos Tribunais, 2005. p. 177178.
} 
Em minucioso acórdão, que merece ser transcrito e endossado, o Desembargador paulista José Luiz Gavião de Almeida observa que a Constituição Federal não equiparou o companheiro ao cônjuge, o que permitiria o tratamento diferenciado entre um e outro, na legislação ordinária, inclusive quanto a aspectos sucessórios e especificamente no que toca ao direito real de habitação:

“À primeira vista poder-se-ia imaginar haver o legislador equiparado a família vinda do casamento daquela que sem ele se formou. Outra parece haver sido a orientação do $\S 3^{\circ}$ do referido artigo 226 da Constituição Federal, que exorta a lei a facilitar a conversão da união estável em casamento.

Fossem as duas situações idênticas, desnecessária seria a conversão.

Exemplos não faltam, na legislação ordinária, de tratamento diverso entre as duas espécies de família. No caso de reconhecimento de filiação, pode ser ele automático em decorrência da existência de uma família legítima. Por exemplo, é possível que a paternidade se estabeleça pela vontade da mãe que, ao fazer o registro de nascimento de seu filho, indique como pai a pessoa com quem ela é casada. Essa é a leitura do artigo 1597 do Código Civil, que presume concebido na constância do casamento os filhos nascidos em situações que indica, e do artigo 1601 do mesmo código que estabelece caber ao marido contestar a paternidade dos filhos nascidos de sua mulher.

A mesma situação não se dá com a família ilegítima. Aqui só o reconhecimento voluntário ou judicial produz efeito (artigo 59 da Lei de Registros Públicos).

Também se pode notar, no artigo $65 \S 2^{\circ}$ da Lei 8245/91, diferenciação entre esses dois tipos de entidade. Esse dispositivo proíbe que o despejo seja executado até o trigésimo dia seguinte ao falecimento do cônjuge, ascendente, descendente ou irmão de qualquer das pessoas que habitem o imóvel. Nada diz a respeito do companheiro. A infração a esse dispositivo caracteriza crime de ação pública, conforme está expresso no artigo 44 IV da mesma lei. Poder-se-ia entender que, analogicamente, a restrição ao despejo acontecesse também na hipótese de haver falecimento do companheiro. Mas não se pode entender que a execução do despejo tipifique o crime do artigo 44 IV citado. Não há previsão para isso. E não há crime, nem se pode aplicar pena, sem prévia lei que o defina (Artigo $5^{\circ}$ XXXIX da Constituição Federal). Por isso não se há de falar que a execução do despejo logo após a morte do companheiro do locatário caracterize o crime do artigo 44 citado, embora a mesma execução, logo após o óbito do cônjuge provoque o ilícito penal.

Tudo isso mostra que não se pode falar em equiparação da família constituída pelo casamento, ou os cônjuges, seus integrantes, com a família formada sem o matrimônio, ou os companheiros ou conviventes. Essa controvérsia, como se disse, deveu-se à ampla proteção à família trazida com a Constituição Federal de 1988. 
Conquanto eruditas e fortes vozes se levantem no sentido de entender ter havido a completa equiparação das famílias, a Constituição Federal de 1988 não pode ser vista encampando esse efeito. Tratou, inicialmente, em dispositivos diversos, da família constituída pelo casamento e da união estável; e mandou que se facilitasse a conversão da união estável em casamento, equiparação inócua se fossem as situações iguais. Sendo diferentes, sequer é possível equiparar as situações por analogia em sede de normas infraconstitucionais. A aplicação analógica, sempre, imporia situação de completa semelhança de tratamento jurídico, o que a Constituição Federal cuidou de vedar pela via do tratamento diferenciado.

Há que se lembrar, ainda, que é nefasta a idéia de equiparação. Assim como se deve ter a liberdade de casar, deve-se garantir a de não casar. E esta última faculdade estaria maculada se as instituições, da família e da união estável, fossem idênticas.

A lei ordinária, é verdade, e a isso não estava proibida, trouxe dispositivos que equiparam o cônjuge ao companheiro. a. a Lei 8245/91, que trata da locação, permite tanto ao cônjuge como ao companheiro suceder o locatário falecido na locação que este mantinha; $b$. o parentesco por afinidade forma-se entre o cônjuge e os parentes de seu aliado ou entre o companheiro e os parentes de seu aliado (artigo 1595); c. a adoção por duas pessoas só poderá ser feita se forem cônjuges ou companheiros (artigo 1618 par. único); d. tanto o cônjuge quanto o companheiro têm direito a alimentos do outro integrante da unidade familiar (artigo 1694); e. tanto a família constituída pelo casamento como a entidade familiar podem invocar, para sua proteção, o instituto do bem de família (artigo 1711 do Código Civil e artigo $1^{\circ}$ da Lei 8009/90); f. tanto o cônjuge como companheiro têm direito sucessório; g. a herança só se torna vacante e é deferida ao Estado se inexistir cônjuge ou companheiro (artigo 1844).

Mas a equiparação, relativa ao direito real de habitação não veio estabelecida no Código Civil de 2002. E não se pode falar que foi esquecimento do legislador, pois ele tratou diferentemente as duas situações. Foi opção legislativa que não cabe ao Judiciário alterar. Podese até criticar, e pretender alteração. Mas não se pode estabelecer o que a lei não estabelece, de forma clara e indiscutível”415.

Percebe-se assim que, com a edição do Código Civil de 2002 - a optar por conferir menos direitos ao convivente do que ao cônjuge -, o companheiro sobrevivente deixou de ter direito real de habitação, seja porque a Lei $n^{\circ}$ 9.278/96 foi revogada globalmente pela nova lei civil, quer por não ser possível a interpretação analógica do artigo 1.831 .

\footnotetext{
${ }^{415}$ TJ/SP, 9a Câm. Dir. Priv., Ap. Cív. no 489.117-4/6-00, Rel. Des. José Luiz Gavião de Almeida, j. 2.10.2007, votação por maioria, vencido o Des. Carlos Stroppa, que entendia não ter o Código Civil de 2002 revogado o direito real de habitação previsto pela Lei n ${ }^{\circ}$ 9.278/96.
} 
Contudo, assinale-se que, apesar de constitucional e de não haver outra juridicamente possível, a solução em comento é injusta, e deveria ser alterada por meio de lei. A esse respeito, tramita o Projeto de Lei $n^{\circ} 6.960 / 2002$, elaborado por Zeno Veloso, pretendendo dar ao artigo 1.790 a redação seguinte:

“Art. 1.790. O companheiro participará da sucessão do outro na forma seguinte:

I - em concorrência com descendentes, terá direito a uma quota equivalente à metade do que couber a cada um destes, salvo se tiver havido comunhão de bens durante a união estável e o autor da herança não houver deixado bens particulares, ou se o casamento dos companheiros se tivesse ocorrido, observada a situação existente no começo da convivência, fosse pelo regime de separação obrigatória (art. 1.641);

II - em concorrência com ascendentes, terá direito a uma quota equivalente à metade do que couber a cada um destes;

III - em falta de descendentes e ascendentes, terá direito à totalidade da herança.

Parágrafo único: Ao companheiro sobrevivente, enquanto não constituir nova união ou casamento, será assegurado, sem prejuízo da participação que lhe caiba na herança, o direito real de habitação, relativamente ao imóvel destinado à residência da família, desde que seja o único daquela natureza a inventariar,"${ }^{, 16}$.

Por fim, por uma questão de zelo, ressaltamos que a extinção do direito real de habitação não atinge os companheiros que o tenham adquirido antes do advento do Código Civil de 2002, cujas disposições só se aplicam às sucessões abertas depois de 11 de janeiro de 2003. Caso o autor da herança tenha falecido antes dessa data, o companheiro sobrevivente continuará gozando de direito real de habitação que já possuísse, até que constitua outra união ou casamento, nos termos do artigo $7^{\circ}$, parágrafo único, da Lei $n^{\circ}$ 9.278/96. Evidentemente, o novo Código Civil não poderia ferir direito adquirido, sob pena de ofensa aos artigos $5^{\circ}$, inciso XXXVI, da Constituição Federal, e $6^{\text {}}$, da Lei de Introdução ao Código Civil ${ }^{417}$.

\footnotetext{
${ }^{416}$ Conforme informa Mauro Antonini (in ANTONINI, Mauro. op. cit., p. 1.785).

${ }^{417}$ Não se está diante da exceção enunciada no item 5.5, pois o caso não é de extinção de um direito real, mas de restrição deste a um grupo de pessoas (cônjuges), em detrimento de outro (companheiros). Por esta razão, a lei nova deverá respeitar o direito adquirido, só se aplicando às sucessões abertas depois de seu advento.
} 


\title{
5.7.2.3. $O$ regime da sucessão do companheiro na hipótese de o artigo 1.790 do Código Civil ser considerado inconstitucional
}

Conforme expusemos no item anterior, endossamos o entendimento de que o artigo 1.790 do Código Civil não é inconstitucional, apesar de merecer reforma. É verdade que toda família merece respeito, proteção e amparo, mas isto não significa data venia dizer que o companheiro - individualmente considerado - goze dos mesmos direitos do cônjuge. No entanto, cumpre-nos mencionar a existência de entendimento diverso. Fazemo-no porque, caso o intérprete entenda que o artigo 1.790 do Código Civil é inconstitucional, deverá aplicar, ao companheiro sobrevivente, regras diversas das expostas nos dois itens anteriores, ao que se fará breve referência abaixo.

De acordo com esta corrente doutrinária, a Constituição Federal teria equiparado o companheiro ao cônjuge, inclusive para fins sucessórios, o que impediria de o artigo 1.790 do Código Civil conferir àquele tratamento diferente deste. Confira-se, por exemplo e por todos, o que sustenta Mauro Antonini:

\begin{abstract}
“(...) as famílias assentadas na união estável ou no casamento são idênticas nos vínculos de afeto, solidariedade e respeito. A diferenciação entre elas se dá pelo modo de sua formação. A Constituição dá preferência ao casamento porque o modo como é formado confere maior segurança jurídica aos nubentes, em termos de prova do enlace, do regime de bens, da data da constituição; o que não significa que possa a lei aviltar a família constituída pela união estável, para forçar companheiros a se casarem. Nos aspectos em que as famílias, oriundas do casamento ou da união estável, são semelhantes, como é o caso das relações afetivas que geram, não pode haver tratamento legal diferenciado. O vínculo familiar, de afeto, solidariedade e respeito, deve ser o norte do legislador infraconstitucional na disciplina da ordem de vocação hereditária. Essa segunda posição parece ser mais adequada, pois, efetivamente, não há distinção, em termos de afeto e dignidade, entre as família constituídas pelo casamento ou união estável. Sem diferenciação entre elas quanto a esse aspecto, parece não ser aceitável que sejam diferenciadas pelo legislador quanto à questão sucessória", ${ }^{118}$.
\end{abstract}

Adotado esse entendimento, o Código Civil de 2002 não teria revogado globalmente as Leis $n^{\circ} 8.971 / 94$ e 9.278/96, que teriam continuado a reger a sucessão do companheiro ${ }^{419}$.

\footnotetext{
${ }^{418}$ in ANTONINI, Mauro. op. cit., p. 1.780.

${ }^{419}$ Mauro Antonini entende em sentido diverso, sustentando que, sendo inconstitucional o artigo 1.790 do

Código Civil, ao companheiro se aplicaria o mesmo regime do cônjuge. Contudo, havendo norma a
} 
Ou seja, adotado o entendimento de que o artigo 1.790 do Código Civil é inconstitucional, teria o companheiro supérstite o direito de herdar a totalidade da herança ou de gozar do usufruto vidual, conforme existissem ou não descendentes ou ascendentes, mais o direito real de habitação.

\subsubsection{A lei aplicável à sucessão testamentária}

O testamento é ato unilateral, personalíssimo e revogável por meio do qual o testador declara sua vontade e dispõe de seus bens para depois da morte (artigos 1.857, caput $^{420}$, $1.858^{421}$ e $1.969^{422}$ do Código Civil), fazendo nascer para o herdeiro testamentário uma expectativa de direito que se concretizará com a abertura da sucessão. Para que surja o direito à sucessão testamentária, é necessária a conjunção de dois elementos autônomos, quais sejam, a declaração do testador e a sua morte.

Conforme adiantamos no item 3.3.2.1, trata-se de um direito de aquisição por elementos autônomos - ou direito de aquisição por partes, na classificação proposta por Rubens Limongi França -, que deve ser regulado pela "aplicação da lei do tempo da perfeição de cada fato aquisitivo" "423. Afirma Wilson de Souza Campos Batalha que "devemos atender, em parte, à lei vigente ao tempo do testamento e em parte à lei vigente ao tempo da abertura da sucessão"424.

De fato, os conflitos de lei no tempo relacionados à sucessão testamentária podem ser resolvidos da seguinte maneira: aplica-se a lei do tempo da elaboração do testamento ao que disser respeito à sua forma e a lei vigente na abertura da sucessão ao que se referir a seu conteúdo. Esta fórmula reside na lógica de que a lei nova não pode se voltar sobre ato jurídico que se perfez na vigência da lei anterior, da confecção do testamento, assim como a lei antiga não poderia regular direito que só viria a nascer na vigência da lei nova, depois da abertura da sucessão. A forma do testamento está perfeita no passado, enquanto seu conteúdo só se tornará direito depois da morte do testador.

disciplinar a matéria - as Leis $\mathrm{n}^{\circ}$ 8.971/94 e 9.278/96, as quais, ante a inconstitucionalidade do artigo 1.790 do Código Civil, não teriam sido revogadas pela nova lei civil -, data venia não haveria lugar para analogia, pois não se poderia falar em lacuna.

${ }^{420}$ Art. 1.857: "Toda pessoa capaz pode dispor, por testamento, da totalidade dos seus bens, ou de parte deles, para depois de sua morte".

${ }^{421}$ Art. 1.858: "O testamento é ato personalíssimo, podendo ser mudado a qualquer tempo".

${ }^{422}$ Art. 1.969: "O testamento pode ser revogado pelo mesmo modo e forma como pode ser feito".

${ }^{423}$ in FRANÇA, Rubens Limongi. Direito intertemporal brasileiro: doutrina da irretroatividade das leis e do direito adquirido, cit., p. 474.

${ }^{424}$ BATALHA, Wilson de Souza Campos. Direito intertemporal, cit., p. 405. 


\subsubsection{Questões relacionadas à forma do testamento}

Ao dizermos aplica-se a lei do tempo da elaboração do testamento ao que disser respeito à sua forma referimo-nos às questões intrinsecamente ligadas ao ato, isto é, as que digam respeito ao testamento em si e não aos direitos decorrentes da sucessão testamentária.

Partindo desse pressuposto, podemos afirmar que se aplica a lei do tempo da elaboração do testamento ao que disser respeito à capacidade de testar (artigo 1.861 do Código Civil $^{425}$ ) e ao que se referir a formalidades do ato, tais como o número de testemunhas, assinatura do testador, leitura do ato, registro do documento etc.

Ensina Wilson de Souza Campos Batalha:

"É, portanto, a lei do tempo da realização do testamento que estabelece as regras acerca da capacidade testamentária ativa (...),426.

"A forma externa dos testamento rege-se pela lei do tempo em que foram feitos, como consequiência do princípio - tempus regit actum. (...) Testamento nulo, por preterição de formalidades essenciais, não se convalesce quando o testador haja falecido na vigência de lei que não mais impunha tais formalidades. (...) Testamento válido ao tempo em que foi realizado (...) não se torna nulo por haver o falecimento do testador ocorrido na vigência de lei que não mais o permitia, desde que observados os requisitos exigidos pelo direito anterior (...)",427.

Portanto, a lei que atribui capacidade testamentária ativa não convalida testamento elaborado por pessoa incapaz antes de seu advento, assim como a que retira - dizendo incapaz quem antes era capaz - não o torna nulo. Da mesma forma, a lei que estabelece formalidades para o testamento não nulifica ato anterior ao seu advento, assim como a que suprime formalidades não confere validade a testamento até então considerado nulo.

\footnotetext{
${ }^{425}$ Art. 1.861: "A incapacidade superveniente do testador não invalida o testamento, nem o testamento do incapaz se valida com a superveniência da capacidade".

${ }^{426}$ BATALHA, Wilson de Souza Campos. Direito intertemporal, cit., p. 408.

${ }^{427}$ Id. Ibid., p. 410-411.
} 


\subsubsection{Questões relacionadas ao conteúdo do testamento}

Ao dizermos aplica-se a lei vigente na abertura da sucessão ao que se referir a seu conteúdo, referimo-nos aos direitos decorrentes do testamento e à legitimação para adquiri-los.

Daí podermos dizer que é a lei da abertura da sucessão a que regula a validade das disposições testamentárias, o rol dos herdeiros necessários, a capacidade para suceder, a quota disponível, o direito de acrescer, as substituições etc. Ensina Wilson de Souza Campos Batalha:

"É a lei vigente ao tempo da morte do testador e não a lei vigente ao tempo da confecção do testamento que regula a validade e eficácia das disposições testamentárias, que define quais são os herdeiros necessários e a quota disponível por testamento, bem como a maneira de calculá-la. A mesma lei dirá se é possível nomear herdeiro ou legatário sob condição, para certo fim ou modo, ou por certa causa; se é válida a cláusula que designe o tempo em que deve começar ou cessar o direito do herdeiro, que instituí-la como herdeiro pessoa incerta, que deixe ao arbítrio do herdeiro ou de outrem fixar o valor do legado, institua herdeiro ou legatário sob condição captatória de que este disponha, também por testamento, em benefício do testador ou de terceiro, o efeito do erro na designação do herdeiro ou do legatário, a validade das cláusulas de inalienabilidade, impenhorabilidade e incomunicabilidade, etc. A mesma lei define a licitude das condição a que se subordinam as disposições testamentárias (por exemplo, a condição do herdeiro instituído não se casar, ou não se casar com certa pessoa, ou não convolar novas núpcias, a conditio viduitatis; a disposição que exclua o usufruto do pai sobre os bens transferidos ao herdeiro instituído)" ${ }^{228}$.

Por meio desta regra será possível resolver a polêmica questão da novel necessidade de justificação das cláusulas restritivas, do que se tratará no item seguinte.

\subsubsection{Os testamentos anteriores ao Código Civil de 2002 e a novel necessidade de justificação das cláusulas restritivas - o artigo 2.042}

Ao contrário do Código Civil de 1916, o Código Civil de 2002 estabeleceu que, para gravar os bens da legítima com cláusula de inalienabilidade, impenhorabilidade e

\footnotetext{
${ }^{428}$ BATALHA, Wilson de Souza Campos. Direito intertemporal, cit., p. 415.
} 
incomunicabilidade, o testador deve apresentar "justa causa" (artigo 1.848, caput $^{429}$ ). Como observa Mauro Antonini,

"O legislador optou pela solução intermediária entre a do Código Civil de 1916, que permitia a livre imposição das cláusulas à legítima, e a propugnada por grande parte da doutrina de abolir essas cláusulas, por retirarem bens do comércio, impedindo a circulação de riquezas, e também por serem resquício de mentalidade patriarcal.

Para alcançar essa solução intermediária, o atual Código assegura o direito ao testador, mas lhe impõe considerável constrangimento para exercê-lo, pois terá de declarar, por exemplo, ser a justa causa para a incomunicabilidade o fato de o genro ser um aproveitador, indicando fatos concretos que justifiquem a pecha. (...) ${ }^{\natural 430}$.

A grande pergunta que se coloca, em direito intertemporal, é saber se a exigência do artigo 1.848, caput, do Código Civil de 2002, de justificação das cláusulas restritivas, aplica-se também aos testamentos celebrados antes de 11 de janeiro de 2003. Para resolver essa questão, bastaria aplicar a regra enunciada alhures: tratando-se de disposição relacionada ao conteúdo do testamento, isto é, aos direitos que dele decorrem, aplica-se o novo Código Civil a todas as sucessões abertas depois do início de sua vigência, mesmo que decorram de testamento anterior ao Código Civil de 2002. Conforme se explicou anteriormente, não haveria aí ofensa ao ato jurídico perfeito, pois, a não ser quanto à forma, este - o ato jurídico perfeito - só existirá depois da morte do testador, a qual é condição necessária para que do testamento surjam direitos - no caso, direito a haver o bem, gravado ou não.

A esse respeito, comenta Mário Luiz Delgado:

"Ora, a exigência de justificação das cláusulas restritivas, ou, melhor dizendo, a proibição de apô-las sem a devida justificação, não é pertinente à forma, mas ao conteúdo das disposições testamentárias. Trata-se de cerceamento à liberdade de testar. Tais cláusulas só serão válidas se permitidas pela lei do tempo da morte do testador",431.

Contudo, o Código Civil de 2002 previu salutar regra transitória segundo a qual a necessidade de justificação das cláusulas restritivas só se aplica às sucessões abertas depois

\footnotetext{
${ }^{429}$ Art. 1.848: "Salvo se houver justa causa, declarada no testamento, não pode o testador estabelecer cláusula de inalienabilidade, impenhorabilidade, e de incomunicabilidade, sobre os bens da legítima".

${ }^{430}$ in ANTONINI, Mauro. op. cit., p. 1.836.

${ }^{431}$ in DELGADO, Mário Luiz. op. cit., p. 144.
} 
de um ano do início de sua vigência, ainda que o testamento tenha sido confeccionado sob a égide do Código Civil de 1916. Durante esse prazo, poderá o testador aditar o testamento, conforme dispõe o artigo 2.042 do Código Civil de 2002: "Art. 2.042. Aplica-se o disposto no caput do art. 1.848, quando aberta a
sucessão no prazo de um ano após a entrada em vigor deste Código, ainda
que o testamento tenha sido feito na vigência do anterior, Lei n. 3.071, de $1^{\circ}$
de janeiro de 1916; se, no prazo, o testador não aditar o testamento para
declarar a justa causa da cláusula aposta à legítima, não subsistirá a
restrição".

Trata-se de um caso de ultratividade propriamente dita, sobre a qual discorremos no item 2.3.3: embora o artigo 1.848, caput, devesse se aplicar a todas as sucessões abertas depois do início de sua vigência, o artigo 2.042 deferiu um prazo durante o qual o dispositivo não se aplica, conferindo ultratividade ao Código Civil de 1916.

\title{
5.7.4. Direito intertemporal e herança jacente/vacante
}

A jacência se dá quando o autor da herança morre sem deixar herdeiros conhecidos. Neste caso, o Estado arrecada os bens deixados pelo de cujus e confere sua administração a um curador, à espera da habilitação dos herdeiros legítimos ou testamentários ${ }^{432}$. Conforme ensina Silvio Rodrigues,

\begin{abstract}
"A herança jaz enquanto não se apresentam herdeiros do de cujus para reclamá-la, não se sabendo se tais herdeiros existem ou não. O Estado, no intuito de impedir o perecimento da riqueza representada por aquele espólio, ordena sua arrecadação, para o fim de entregá-lo aos herdeiros que aparecerem e demonstrarem tal condição"433.
\end{abstract}

Caso nenhum herdeiro se habilite no prazo de um ano a contar da publicação do primeiro edital que os haja convocado ${ }^{434}$, a herança será declarada vacante, ou seja, a que

\footnotetext{
${ }^{432}$ Art. 1.819 do Código Civil: "Falecendo alguém sem deixar testamento nem herdeiro legítimo notoriamente conhecido, os bens da herança, depois de arrecadados, ficarão sob a guarda e administração de um curador, até sua entrega ao sucessor devidamente habilitado ou à declaração de sua vacância".

${ }^{433}$ in RODRIGUES, Silvio. Direito civil: direito das sucessões, cit., p. 81.

${ }^{434}$ Art. 1.820 do Código Civil: "Praticadas as diligências de arrecadação e ultimado o inventário, serão expedidos editais na forma da lei processual, e, decorrido 1 (um) ano de sua primeira publicação, sem que haja herdeiro habilitado, ou penda habilitação, será a herança declarada vacante".
} 
"judicialmente foi proclamada de ninguém" "435. Com a declaração de vacância, a herança é devolvida ao Município em que estiver situada ${ }^{436}$, que adquirirá sua propriedade definitiva depois de cinco anos da abertura da sucessão ${ }^{437}$.

Quando há jacência, apenas depois de cinco anos da morte do de cujus é que o Município adquire a propriedade definitiva do imóvel ${ }^{438}$ - até lá, os herdeiros poderão reclamar a herança, à exceção dos colaterais ${ }^{439}$. Como é de se imaginar, esse longo lapso pode acarretar problemas de direito intertemporal, pois não raras vezes ocorre de uma lei nova alterar o procedimento da jacência antes da declaração de vacância.

A questão da herança jacente foi palco para o episódio mais obscuro do direito intertemporal brasileiro: assim como no Código Civil de 2002, no Código Civil de 1916 a herança só poderia ser declarada vacante à falta de parentes sucessíveis, dentre os quais se incluíam os colaterais até o quarto grau ${ }^{440}$. Casuisticamente, no entanto, o Governo Vargas do Estado Novo editou Decreto-lei considerando jacente a herança de que não se encontrassem parentes sucessíveis até o segundo grau. Este o texto do artigo $1^{\circ}$ do Decreto-lei $\mathrm{n}^{\circ} 1.907 / 39$, de acordo com Washington de Barros Monteiro:

\begin{abstract}
"Além dos casos previstos no Código Civil, considera-se jacente a herança se o falecido, nacional ou estrangeiro, tiver sido solteiro ou viúvo e não houver deixado testamento nem ascendente, descendente ou irmãos herdeiros e sobreviventes, notoriamente conhecidos" ${ }^{, 41}$.
\end{abstract}

Segundo informa o autor, o referido Decreto-lei teve como objetivo alcançar a sucessão de Paul Deleuse, morto meses antes e cuja fortuna teria sido adquirida "por meio tortuosos". De

${ }^{435}$ in RODRIGUES, Silvio. Direito civil: direito das sucessões, cit., p. 84.

${ }^{436}$ Art. 1.844 do Código Civil: "Não sobrevivendo cônjuge, ou companheiro, nem parente algum sucessível, ou tendo eles renunciado a herança ( sic), esta se devolve ao Município ou ao Distrito Federal, se localizada nas respectivas circunscrições, ou à União, quando situada em território federal".

${ }^{437}$ Art. 1.822 do Código Civil: "A declaração de vacância da herança não prejudicará os herdeiros que legalmente se habilitarem; mas, decorridos 5 (cinco) anos da abertura da sucessão, os bens arrecadados passarão ao domínio do Município ou do Distrito Federal, se localizados nas respectivas circunscrições, incorporando-se ao domínio da União quando situados em território federal".

${ }^{438}$ Exceto se todos os herdeiros renunciarem à herança, hipótese em que esta será considerada desde logo vacante, conforme preceitua o artigo 1.823 do Código Civil: "Quando todos os chamados a suceder renunciarem à herança, será esta desde logo considerada vacante".

${ }^{439}$ Artigo 1.822, parágrafo único: "Não se habilitando até a declaração de vacância, os colaterais ficarão excluídos da sucessão”.

${ }^{440}$ Artigo 1.612 do Código Civil de 1916: "Se não houver cônjuge sobrevivente, ou ele incorrer na incapacidade do art. 1.611, serão chamados a suceder os colaterais até o quarto grau". Artigo 1.839 do Código Civil de 2002: "Se não houver cônjuge sobrevivente, nas condições estabelecidas no art. 1.830, serão chamados a suceder os colaterais até o quarto grau".

${ }^{441}$ in MONTEIRO, Washington de Barros. Curso de direito civil: direito das sucessões, cit., p. 77-78. 
forma a evitar que seus bens fossem adquiridos por sobrinho situado no estrangeiro, o Decretolei $n^{\circ} 1.907 / 39$ alterou o procedimento de jacência, retroativamente, atingindo a sucessão de Paul Deleuse - cuja herança deixou de ser de seu sobrinho para passar a ser do Estado ${ }^{442}$.

Embora questionado pelo Ministério Público, o Decreto-lei nº 1.907/39 foi considerado constitucional e o Promotor aposentado, a bem do regime. Somente com o Decreto-lei $\mathrm{n}^{\circ}$ 9.461/46 a capacidade sucessória dos colaterais foi novamente estendida ao quarto grau, o que teria ocorrido também casuisticamente, para se alcançar os bens de Hildebrando Cantinho Cintra. O resgate histórico é do crédito de Washington de Barros Monteiro, cujo relato merece ser transcrito:

\begin{abstract}
"Por outras palavras, referido diploma restringiu o conceito de colateral sucessível, reduzindo-o do sexto para o segundo grau apenas. Sobrinhos (parentes em terceiro grau) só herdavam através do direito de representação, desde que concorressem com irmãos do de cujus. Se este, porém, não deixasse irmãos sobreviventes, que lhe recolhessem a herança, excluíam-se também os sobrinhos.
\end{abstract}

Ao mencionado decreto-lei atribuiu-se expressamente efeito retroativo, a fim de alcançar os processos em curso. Visou ele alcançar, como é notório, a sucessão de Paul Deleuse, aberta meses antes de sua promulgação. Carlos Maximiliano, em voto proferido no Supremo Tribunal Federal, assim procurou explicar a retroatividade do diploma legal: a opulência daquele estrangeiro fora adquirida por meios tortuosos, tais que, ao se abrir inquérito para apurá-los, não achou ele outra porta para escapar senão o suicídio. Sobreveio então a lei, colimando impedir que a fortuna, havida em detrimento do Estado, fosse parar nas mãos de alienígenas. Sustentou-se que o direito do herdeiro, ao tempo da abertura da sucessão, era presumido, podendo destarte ser alterado por fatos e por lei nova, sem que isso constituísse expropriação independente de prévia indenização.

Houve, àquele tempo, representante do Ministério Público que contestou a força retroativa do Decreto-lei n. 1907, opinando pela decretação de sua inconstitucionalidade. Esse funcionário foi aposentado a bem do regime, em conformidade com o art. 177 da Carta Constitucional então em vigor. Aliás, perante a justiça, a tese que prevaleceu foi a da constitucionalidade da lei.

Essa fase de nosso direito sucessório, no capítulo relativo à herança jacente, foi superado no Governo Linhares, que expediu o Decreto-lei n. 8.207, de 22 de novembro de 1945, revogando o de n. 1.907 e reduzindo de trinta para cinco anos o prazo do art. 1.594 do Código Civil. Além disso, ampliou o conceito de colateral sucessível, de molde a abranger parentes de terceiro grau (sobrinhos e tios).

\footnotetext{
${ }^{442}$ Curioso notar que a retroação sobre direito adquirido (no caso, o direito que o sobrinho de Paul Deleuse já havia adquirido sobre a herança) foi possível porque a Constituição Federal de 1937 não trouxe qualquer dispositivo a respeito, possibilitando desmandos infraconstitucionais, como ocorreu com o Decreto-lei $\mathrm{n}^{\circ}$ 1.907/39. Eis um dos reflexos do espírito totalitário a que nos referimos no item 2.5.1.
} 
Finalmente, no Governo Dutra, baixou-se o Decreto-lei n. 9.461, de 15 de julho de 1946, que alargou até o quarto grau (primos-irmãos, tios-avós e sobrinhos-netos) a capacidade sucessória dos colaterais. Esse o direito vigente até esta data, inclusive de acordo com o Código Civil de 2002. Segundo se apregoa, essa disposição legal, mercê de prestigiosas influências, teria sido expedida ad hominem, a fim de alcançar a arrecadação dos bens deixados por Hildebrando Cantinho Cintra (...),"443.

Questão de grande interesse prático é a seguinte: até 1990 a herança vacante era devolvida às instituições de desenvolvimento do ensino, e g. a Universidade de São Paulo, por força do Decreto-lei $n^{\circ}$ 8.207/45. Contudo, com a edição da Lei $n^{\circ}$ 8.049/90 a herança vacante passou a ser devolvida aos Municípios, surgindo a pergunta: qual a lei aplicável às sucessões abertas antes da vigência da Lei $\mathrm{n}^{\circ}$ 8.049/90 mas que só tenham sido declaradas vacantes depois de seu advento?

Para responder a esta indagação, é necessário estabelecer em que momento o Município adquire o direito à herança, se na abertura da sucessão ou apenas com a declaração de vacância. Tem prevalecido no Superior Tribunal de Justiça o entendimento de que o Município só adquire a propriedade da herança com a declaração de vacância, o que impõe a aplicação da lei nova às sucessões abertas antes de sua vigência. Confira-se voto do Ministro Barros Monteiro:

\footnotetext{
“(...) a declaração de vacância é o momento em que o domínio dos bens jacentes se transfere ao patrimônio público. Ocorrida a declaração de vacância após a vigência da Lei n. 8.049 de 20.06.1990, legitimidade cabe aos Municípios para recolher os bens jacentes" ${ }^{\text {"444 }}$.
}

Por outro lado, há quem sustente, também no Superior Tribunal de Justiça, que, apesar de o Município só adquirir a propriedade da herança com a declaração da vacância, o destinatário dos bens vacantes deveria ser determinado pela lei vigente ao tempo da abertura da sucessão, pois é esta lei que regula a capacidade para suceder. Nesse sentido é o entendimento do Ministro Ruy Rosado de Aguiar:

"Esta eg. $4^{\mathrm{a}}$ Turma, em julgados de minha relatoria, tem entendido que a consolidação do domínio da herança jacente somente ocorre depois de

\footnotetext{
${ }^{443}$ in MONTEIRO, Washington de Barros. Curso de direito civil: direito das sucessões, cit., p. 78-79.

${ }^{444}$ STJ, 4 a Turma, REsp n ${ }^{\text {1 }}$ 100.290/SP, rel. Min. Barros Monteiro, j. 14.5.2002, v.u. (in ANTONINI, Mauro. op. cit., p. 1.815).
} 
decorrido o período de cinco anos da declaração da vacância, nos expressos termos do artigo 1594 do C. Civil, permitindo por isso mesmo a prescrição aquisitiva em favor do possuidor, enquanto essa transmissão não acontecer (RESP 13.414-0-RJ; AGR 35.437-9-SP).

No caso dos autos, porém, a questão não está em saber quando se dá a transmissão de domínio da herança jacente para o Estado ou Município, mas sim em estabelecer qual o ente que poderia se habilitar à herança, no momento em que foi aberta a sucessão. Nos termos do artigo 1557 do C. Civil, essa capacidade é a do tempo da abertura da sucessão.

Ao tempo da morte do titular do espólio, quem estava habilitado por lei a se beneficiar com a declaração de vacância era o Estado (artigo 1.594 do Código Civil, com antiga redação). Definida essa situação, ao tempo da abertura da sucessão, incide a regra do artigo $1.577 \mathrm{CC}$, sendo irrelevante que a sentença de vacância, com a devolução dos bens ao ente público, e a consolidação do seu domínio, cinco anos depois, ocorram quando já vigente outra lei, autorizando a transferência do domínio dos bens da herança jacente ao Município" ${ }^{945}$.

Com o devido respeito ao entendimento dos doutos Ministros, tais argumentos não podem ser acatados. Esse entendimento desconsidera o princípio de saisine, levando à conclusão de que a herança teria ficado sem sujeito até a declaração da vacância - o que data venia é um contra-senso, pois se estaria a admitir um direito sem sujeito, mesmo que provisoriamente ${ }^{446}$. Contra essa possibilidade, Pontes de Miranda é enfático:

\begin{abstract}
"Ora, o Estado é herdeiro legítimo (Código Civil, art. 1.603) e a interpretação do art. 1.619, como se a expressão 'se devolve' significasse que se transmitem - e só então - o domínio e a posse, ofenderia ao princípio da saisina. $\mathrm{O}$ art. 1.594, esse refere-se à entrega, que há de ser à entidade estatal que seja a legitimada, mas o art. 1.594 é de má redação, que se não há de refletir no sistema jurídico. Desde que houve a morte, a titularidade do direito transmite-se, automaticamente, aos herdeiros legítimos e testamentários. Ninguém, ex hipothesi, sem ser o Estado, teve o domínio e a posse mediata enquanto decorreu o tempo entre a morte do decujo e a declaração de vacância"447.
\end{abstract}

\footnotetext{
${ }^{445}$ STJ, $4^{\text {a }}$ Turma, REsp 61885/SP, Rel. Min. Ruy Rosado de Aguiar, j, 12.9.2005, v.u.

${ }^{446}$ Dos julgados pesquisados, fica a sensação de que o Superior Tribunal de Justiça passou a decidir nesse sentido para permitir a usucapião da herança jacente, evitando que o Município pudesse tomar do possuidor bem onde já estivesse instalado há muitos anos. A se admitir que o princípio da saisine se aplica ao Poder Público, este já teria adquirido a herança desde a abertura da sucessão, o que impediria a usucapião dos bens que lhe compõem o acervo - públicos desde a morte do autor da herança, e portanto não usucapíveis. Apesar de justa, a orientação não parece a melhor do ponto de vista técnico.

${ }^{447}$ in MIRANDA, Francisco Cavalcanti Pontes de. Tratado de direito privado. Rio de Janeiro: Borsoi, 1972. t. 55, p. 246. Pouco importa que o Município não mais conste do rol dos herdeiros legítimos. O fato de não figurar no artigo 1.829 do Código Civil não lhe retira a qualidade de ente sucessor - atribuída, sob condições, pelo artigo 1.844 do Código Civil -, assim como não deixa de ser sucessor o companheiro, o qual também não consta deste dispositivo - mas sim do artigo 1.790 do Código Civil. Para que não pairem dúvidas, confira-se o entendimento do Desembargador Sebastião Luiz Amorim: "Há de se notar que o
} 
De fato, a sentença que declara a vacância é meramente declaratória de um direito adquirido desde o momento da abertura da sucessão. Nesse contexto, há de se aplicar à herança vacante a lei vigente ao tempo da morte do de cujus, em respeito ao princípio da saisine e ao artigo 1.784 do Código Civil. Logo, a Lei ${ }^{\circ}$ 8.049/90 não se aplica às sucessões abertas antes de seu advento, mesmo que a herança só tenha sido declarada vacante depois.

\subsubsection{A lei aplicável aos tributos incidentes sobre a sucessão causa mortis - a questão do ITCMD e do IR}

Conforme trataremos no item 6.3, no direito tributário a retroatividade é expressamente vedada pela Constituição Federal. De acordo com o artigo 150, inciso III, alínea $a$, a lei tributária só pode ser aplicada a fatos geradores iniciados ou completados depois do início de sua vigência. Além disto, dispõe o artigo 150, inciso III, alíneas $b$ e $c$, ser proibido cobrar ou aumentar tributo no mesmo exercício financeiro e antes de noventa dias da publicação da lei que os haja instituído ou aumentado, salvo nos casos em que a própria Constituição Federal excepcionar estas regras, denominadas anterioridade e anterioridade nonagesimal.

Logo, a lei tributária aplica-se apenas aos fatos geradores posteriores ao início de sua vigência e desde que não haja instituído ou aumentado tributo - hipótese em que, em geral, só será exigível no exercício financeiro seguinte e depois de noventa dias de sua publicação.

Código Civil de 2002 corrige imperfeição da ordem de vocação hereditária (legítima), excluindo os Municípios, o Distrito Federal e a União do rol de herdeiros (arts. 1.829 a 1.843).

São essas entidades sucessoras, com direito de receber o patrimônio deixado pelo falecido, na falta de herdeiros (art. 1.844).

Não consideradas como herdeiras, a elas não se aplicam algumas regras do direito sucessório, entretanto a natureza do direito é sucessória.

(...)

(...) na falta de outras pessoas sucessíveis, por lei ou por testamento, herda o Município em reconhecimento da colaboração prestada ao indivíduo na aquisição e conservação da riqueza. Por índole e por conteúdo seu direito não diversifica do outorgado aos demais herdeiros e com precedência legal (...)". (in AMORIM, Sebastião Luiz. Herança jacente e vacante no atual Código Civil. In: DELGADO, Mário Luiz; ALVES, Jones Figueiredo (Coords.). Questões controvertidas no novo Código Civil. São Paulo: Método, 2005. v. 3, p. 362-363). Em sentido contrário, a opinião de Francisco Eduardo Loureiro: "No que se refere à herança jacente, os arts. 1.829 e 1.844 do atual Código Civil deixam claro que o Estado não é herdeiro, por não se encontrar na ordem de vocação hereditária, mas recebe a herança, na falta ou renúncia dos herdeiros. Não se aplica ao Estado o direito de saisine, ou seja, não se torna proprietário e possuidor no momento da morte, havendo necessidade da sentença de vacância dos bens. É esse o entendimento majoritário da jurisprudência (...), embora haja precedente do Supremo Tribunal Federal no sentido de que a sentença é declaratória e retroage à data na qual o óbito completa cinco anos, sem habilitação de herdeiros (...)" (in LOUREIRO, Francisco Eduardo. Código Civil comentado: doutrina e jurisprudência. Coord. Cezar Peluso. Barueri: Manole, 2007. p. 1.061). 
Considerando-se que, ante o princípio da saisine, a morte constitui fato gerador do Imposto Sobre Transmissão Causa Mortis e Doação de Quaisquer Bens ou Direitos (“ITCMD”), outra não poderia ser a conclusão senão a de que este deve ser regulado pela lei vigente ao tempo da abertura da sucessão, mas observando-se que, se tiver havido aumento do imposto, a alíquota majorada só poderá ser exigida para as sucessões abertas no exercício financeiro seguinte e depois de noventa dias da publicação da lei que haja majorado o tributo.

Referenda a Súmula no 112 do STF: “o Imposto de Transmissão Causa Mortis é devido pela alíquota vigente ao tempo da abertura da sucessão".

Nesse contexto, o contribuinte não poderá, e.g., se beneficiar de isenção veiculada por lei posterior à morte do autor da herança, conforme já o decidiu o Superior Tribunal de Justiça, em voto relatado pelo Ministro Luiz Fux:

\section{"TRIBUTÁRIO - IMPOSTO DE TRANSMISSÃO CAUSA MORTIS - LEI $10.705 / 00 \quad-\quad$ SENÇÃO - RETROATIVIDADE - IMPOSSIBILIDADE.}

1. A regra basilar em tema de direito intertemporal é expressa na máxima tempus regit actum. Assim, o fato gerador, com os seus consectários, rege-se pela lei vigente à época de sua ocorrência.

2. O Imposto de Transmissão tem como fato gerador, in casu, a transmissão causa mortis da propriedade, que no direito brasileiro coincide com a morte, por força do direito de sucessão.

3. Ocorrido o fato gerador do tributo anteriormente à vigência da lei que veicula isenção, inviável a aplicação retroativa, porquanto, in casu, não se trata de norma de caráter interpretativo ou obrigação gerada por infração (art. 106 do CTN).

4. Tratando-se de norma concessiva de exoneração tributária, sua interpretação é restritiva (art. 111, III do CTN), observada a necessária segurança jurídica que opera pro et contra o Estado. Inteligência do art. 106 do CTN"448.

O mesmo raciocínio se aplica à exigência do Imposto Sobre a Renda e Proveitos de Qualquer Natureza ("IR") nos casos em que a sucessão representar um ganho de capital. Nessa hipótese, aplicam-se as regras da lei vigente no momento da morte do de cujus, respeitado

\footnotetext{
${ }^{448}$ STJ, $1^{\text {a }}$ Turma, REsp 464419/SP, Rel. Min. Luiz Fux, j. 15.5.2003., v.u.
} 
o princípio da anterioridade ${ }^{449}$. Nesse sentido já decidiu o Superior Tribunal de Justiça, em voto da Ministra Denise Arruda:

“TRIBUTÁRIO. IMPOSTO DE RENDA. GANHO DE CAPITAL DECORRENTE DA TRANSFERÊNCIA DE BENS E DIREITOS POR SUCESSÃO HEREDITÁRIA. IMPOSSIBILIDADE DE APLICAÇÃO RETROATIVA DO ART. 23 DA LEI 9.532/97.

1. O art. 81, II, da Lei 9.532/97, fixou o início da vigência do art. 23 da mesma lei a partir de $1^{\circ}$ de janeiro de 1998. O Tribunal de origem, em face do que dispõe o art. 1.572 do Código Civil de 1916, decidiu pela inaplicabilidade, ao presente caso, da Lei 9.532/97, que foi editada em data posterior à abertura da sucessão, conforme entendimento assim ementado: '1. A solução da controvérsia trazida à colação está em fixar o momento da transmissão da herança e, partindo deste, em aplicar o princípio da irretroatividade da lei tributária. 2. O artigo 1.572 do antigo Código Civil, em vigor ao tempo do falecimento do autor da herança, transmitiam-se, desde logo, aos herdeiros legítimos e testamentários, no que encontra correspondência no artigo 1.784 do novo Código Civil. 3. Adotou-se o princípio originário do droit de saisine, que dá à sentença de partilha caráter meramente declaratório, haja vista que a transmissão dos bens aos herdeiros e legatários se dá no momento do óbito do transmitente. 4. As regras a serem observadas na transmissão da herança serão aquelas em vigor ao tempo do óbito do de cujus que, no caso em tela, e no que tange à incidência do Imposto de Renda, encontravam-se na Lei 7.713/88. 5. Dispunha o citado diploma legal, no inciso XIV, do artigo $6^{\circ}$, e no inciso III, do artigo 22, que o valor dos bens adquiridos por herança serão isentos do imposto de renda e que as transferências causa mortis serão excluídas do ganho de capital dos herdeiros e legatários. 6. A tese defendida pela recorrida, de que o fato gerador do imposto na espécie, a ensejar o recolhimento do imposto, é o acréscimo patrimonial decorrente da reavaliação patrimonial dos bens constantes da última declaração do de cujus, há de ser refutada, haja vista que faz incidir ao caso em comento sistemática criada por lei posterior à transmissão dos bens deixados pelo transmitente, que se deu sob a égide da Lei 7.713/1988, com conseqüente violação do princípio da irretroatividade das leis tributárias.'

2. Em assim decidindo, a Turma Regional não contrariou o art. 23 da Lei 9.532/97; ao contrário, deu-lhe interpretação consentânea com a lei civil, observando, ainda, o disposto nos arts. 104, 105 e 116 do Código Tributário Nacional” ${ }^{\prime 450}$.

Concluímos, assim, que, observados os princípios da anterioridade e da anterioridade nonagesimal, quando aplicáveis, as questões tributárias relacionadas à sucessão causa mortis regem-se pelas mesmas regras delineadas para os direitos de aquisição simples (item 3.3.1),

\footnotetext{
${ }^{449}$ Ao IR não se aplica o princípio da anterioridade nonagesimal, por expressa disposição artigo $150, \S 1^{\circ}$, da Constituição Federal.

${ }^{450}$ STJ, $1^{\text {a }}$ Turma, REsp n ${ }^{\circ}$ 805806/RJ, Rel. Min. Denise Arruda, j. 13.11.2007, v.u.
} 
tendo em vista que seu fato gerador dá azo a direitos adquiridos em um momento único direito de o contribuinte pagar um determinado valor, sem aumentos, e do Fisco de recebêlo, sem reduções. 


\section{SEXTA PARTE. SISTEMAS ESPECIAIS DE DIREITO INTERTEMPORAL}

\subsection{Considerações gerais}

Conforme visto, o Brasil possui um sistema peculiar de direito intertemporal, que, em linhas gerais, pauta-se (1) pelo efeito imediato, segundo o qual a lei nova age para dela em diante, atingindo fatos presentes, futuros e pendentes - os que nascem ao tempo de uma determinada lei e continuam a produzir efeitos na vigência de outra que a tenha revogado; (2) pela proteção ao direito adquirido, ao ato jurídico perfeito e à coisa julgada, os quais limitam o efeito imediato da lei nova, garantindo ultratividade aos efeitos da lei revogada; (3) pela inexistência de uma proibição a priori à retroatividade, a qual poderá ocorrer, de forma expressa, se não afrontar o direito adquirido, o ato jurídico perfeito e a coisa julgada. Desta forma, independentemente do efeito da lei revogadora, os problemas de direito intertemporal podem ser resolvidos pela regra "aplica-se a lei nova desde que não ofenda o direito adquirido, o ato jurídico perfeito e a coisa julgada”. Deverá o intérprete analisar se, no caso concreto, existe uma destas três figuras, caso em que deverá garantir ultratividade aos efeitos da lei anterior.

Este sistema é universal, resolvendo a generalidade das questões de direito intertemporal, em qualquer ramo da atividade jurídica. Não há dificuldades, senão a de verificar se se está diante de direito adquirido, ato jurídico perfeito e coisa julgada. Para tanto, dever-se-á analisar se o direito integra o patrimônio do titular, para o que não existe uma fórmula, mas apenas diretrizes - aqui, confessamos, o intérprete terá grande trabalho, seja qual for sua área de atuação.

A título de exemplo: para dizer se o herdeiro tem direito à herança, deverá verificar quando se deu a morte; para julgar a validade de um contrato, deverá analisar os requisitos exigidos ao tempo de sua elaboração; para decidir pelos juros aplicáveis, deverá questionar se decorriam da lei ou de ajuste entre as partes. Procuramos analisar as principais questões suscitadas pelo advento do Código Civil de 2002, o que poderia também ser feito com as demais ciências, como o direito processual civil, o direito administrativo, o direito ambiental etc, respeitados os pressupostos que cada uma delas impõe para a aquisição de um direito.

Contudo, devemos ressalvar que ao menos dois ramos da atividade jurídica possuem um sistema próprio de direito intertemporal, com princípios e regras distintas das enunciadas 
anteriormente. Diferentemente do que se dá com o sistema geral de direito intertemporal, no direito penal e no direito tributário a retroatividade da lei nova é expressamente proibida quando desfavorável, e necessária - não só admitida como determinada - quando favorável ao réu ou ao contribuinte.

Tanto em um como em outro, o princípio da irretroatividade ganha um significado próprio, de não-retroatividade e de proibição ao efeito imediato, quando na teoria geral do direito intertemporal este princípio se materializa na proteção do direito adquirido, a garantir ultratividade aos efeitos da lei revogada.

Dada esta diferença crucial, analisaremos brevemente estes dois sistemas especiais de direito intertemporal, muito embora não sejam objeto deste trabalho. A nosso ver isto é imprescindível, de modo a que não sejam aplicadas ao direito intertemporal brasileiro regras e princípios específicos destas duas matérias - como de fato ocorre, a ponto de se entoar o mantra, absolutamente falso, de que a retroatividade seria proibida (equívoco que, não custa lembrar, tem origem na importação de regras alienígenas sem aplicação em nosso sistema).

\subsection{Direito Intertemporal Penal}

Espinha dorsal do direito penal, o princípio da reserva legal proíbe que a lei nova criminalize fato ocorrido no passado. Tal princípio está consagrado legal e constitucionalmente, nos artigos $1^{\circ}$ do Código Penal e $5^{\circ}$, inciso XXXIX, da Constituição Federal:

\footnotetext{
“Art. $1^{\circ}$. Não há crime sem lei anterior que o defina. Não há pena sem prévia cominação legal".

“Artigo 5 $5^{\circ}$ (...)

$(\ldots)$

XXXIX. não há crime sem lei anterior que o defina, nem pena sem prévia cominação legal"
}

Conseqüentemente, outra não poderia ser a regra senão a de que a lei nova, no direito penal, não poderá jamais retroagir para prejudicar o réu, como observa Edgard Magalhães Noronha ao afirmar que "como decorrência do princípio nullum crimen, nulla poena sine 
praevia lege, segue-se o da irretroatividade da lei penal. É claro que, se não há crime sem lei, não pode esta retroagir para alcançar um fato que, antes dela, não era considerado delito" ${ }^{451}$. Daí o princípio da irretroatividade ter sido consagrado, no direito penal, como a proibição à retroatividade da lei nova - entendida em sentido amplo, de modo a abranger não só os fatos passados como também os pendentes (raciocínio que, repita-se, não pode ser transportado para a teoria geral do direito intertemporal). Dispõem os artigos $2^{\circ}$, caput, do Código Penal, e $5^{\circ}$, inciso XL, da Constituição Federal:

“Art. $2^{\circ}$. Ninguém pode ser punido por fato que lei posterior deixa de considerar crime, cessando em virtude dela a execução e os efeitos penais da sentença condenatória".

“Art. $5^{\circ} .(\ldots$.

(...)

XL. a lei penal não retroagirá (...)”.

Contudo, por razões óbvias de humanidade, consagrou-se a máxima de que a lei nova, quando benéfica, deve ser aplicada às situações em curso e às passadas, mesmo que já transitadas em julgado. Trata-se da retroatividade da lei benigna, consagrada pelo Código Penal, pela Constituição Federal e pela Convenção Americana de Direitos Humanos, artigos $2^{\circ}$, parágrafo único, $5^{\circ}$, inciso XL, segunda parte, e $9^{\circ}$, respectivamente:

“Art. $2^{\circ} .(\ldots)$

Parágrafo único. A lei posterior, que de qualquer modo favorecer o agente, aplica-se aos fatos anteriores, ainda que decididos por sentença condenatória transitada em julgado".

“Art. $5^{\circ}(\ldots)$

(...)

XL. a lei penal não retroagirá, salvo para beneficiar o réu".

"Art. $9^{\circ}$. Ninguém pode ser condenado por ações ou omissões que, no momento em que foram cometidas, não sejam delituosas, de acordo com o direito aplicável. Tampouco se pode impor pena mais grave que a aplicável no momento da perpetração do delito. Se depois da perpetração do delito a lei dispuser a imposição de pena mais leve, o delinqüente será por isso beneficiado".

${ }^{451}$ NORONHA, Edgard Magalhães. Direito penal. 28. ed. atual. por Adalberto José Q. T. de Camargo Aranha. São Paulo: Saraiva, 1991. v. 1, p. 75. 
A lei benigna é sempre ultrativa, de efeito imediato e retroativa, projetando efeitos para depois de sua revogação e aplicando-se aos fatos pendentes e passados.

Analisamos a seguir as espécies de leis benignas, a abolitio criminis e a novatio legis in mellius.

\subsubsection{As leis penais benignas - abolitio criminis e novatio legis in mellius}

A abolitio criminis é a lei que deixa de considerar crime um fato antes delituoso. $\mathrm{O}$ artigo 107, inciso III, do Código Penal ${ }^{452}$, trata-a como causa de extinção da punibilidade, que dá cabo tanto à pretensão punitiva (poder de instaurar a ação penal) como à pretensão executória (dever de exigir o cumprimento da pena). A abolitio criminis põe fim a todos os efeitos penais da condenação (e.g. reincidência e maus antecedentes), mesmo que ocorra depois do trânsito em julgado da sentença penal condenatória. Só não apaga os efeitos civis, tendo em vista que o dever de indenizar decorre do ilícito civil e não do caráter criminoso do evento danoso.

Julio Fabbrini Mirabete e Renato N. Fabbrini ensinam que:

“(...) Ocorrerá a extinção da punibilidade prevista no art. 107, III, do CP. O sentenciado será posto em liberdade se estiver cumprindo pena, voltará à condição de primário, não estará mais submetido ao sursis ou livramento condicional etc.

\section{(...)}

Pela abolitio criminis se fazem desaparecer o delito e todos seus reflexos penais, permanecendo apenas os civis. Nesta parte, a sentença condenatória transitada em julgado, sem embargo da abolitio criminis, torna certa a obrigação de indenizar o dano causado pelo crime (art. 91, inc. I, do CP). Isto porque já ficou reconhecido em juízo a ocorrência do fato e estabelecida sua autoria; o fato já não é crime, mas um ilícito civil que obriga à reparação do dano. $\mathrm{O}$ art. $2^{\circ}$, caput, do $\mathrm{CP}$, portanto, não tem efeitos civis ou processuais civis" ${ }^{\prime 453}$.

452، Art. 107. Extingue-se a punibilidade:

(...)

III - pela retroatividade da lei que não mais considera criminoso o fato".

${ }^{453}$ MIRABETE, Julio Fabbrini; FABBRINI, Renato N. Manual de direito penal. 24. ed. rev. e atual. São Paulo: Atlas, 2007. v. 1, p. 42. 
Já a novatio legis in mellius é toda lei que beneficia o réu sem abolir o crime (por exemplo, a lei que diminui a pena, permite a progressão de regimes, diminui prazos de prescrição etc). Também tem efeito imediato e retroativo, atingindo as situações pendentes e passadas, mesmo que definitivamente julgadas.

A novatio legis in mellius não é de fácil aferição, devendo o intérprete analisar se realmente beneficia o réu, o que deve levar em conta as particularidades do caso concreto. A doutrina auxilia. Tome-se, por exemplo, a lição de Edgard Magalhães Noronha:

\begin{abstract}
"Abrange todas as hipóteses possíveis de benefícios, todas as situações que sejam mais benignas. Isto é, tudo o que seja favorável ao réu ou ao condenado.

Exemplificando: circunstâncias novas atenuantes, causas extintivas de punibilidade até então desconhecidas, novos benefícios como o sursis e o livramento condicional, causas de exclusão da antijuridicidade introduzidas, penas menos rigorosas etc $"$ "454.
\end{abstract}

Controvertida também é a possibilidade de combinação das leis nova e revogada, tomando-se os aspectos benéficos de uma e de outra. Em desfavor, argumenta-se que, ao combinar a lei revogadora com a lei revogada, o Juiz estaria criando uma terceira lei, o que lhe é vedado; a favor da combinação de leis, afirma-se que, se o juiz pode aplicar a lei nova "no todo", poderia também, a benefício do réu, aplicar apenas algum de seus aspectos. Esta seria uma solução mais justa, por beneficiar o réu. Aparentemente a favor desta tese, confirase novamente a lição de Edgard Magalhães Noronha:

"Ponto em que a doutrina não se concilia é no tocante à combinação de leis, para aplicação ao caso concreto.

Objeta-se que o juiz não pode combina-las (sic) para extrair delas um conteúdo mais favorável ao réu; ele estaria, em tal hipótese, elaborando uma lei, o que não lhe é permitido (...).

Não faltam, entretanto, os que pensam de maneira diversa (...) invocando a eqüidade e (...) observando que o juiz, em tal caso, obedece a princípio constitucional e joga com elementos fornecidos pelo próprio legislador. Se lhe é dado, na aplicação do mandamento constitucional, escolher entre duas leis a que é mais benigna, não se vê por que não se admitir que as combine para assim melhor obedecer à Lei Magna. Se pode escolher o 'todo' para favorecer o réu, poderá também tirar parte de um todo para combinar com a parte de outro todo, em obediência ainda ao preceito constitucional.

\footnotetext{
${ }^{454}$ NORONHA, Edgard Magalhães. op. cit., p. 76.
} 
Tal opinião é aceitável. Ela apresenta solução equânime no período transitório entre duas leis, e é consentânea com o princípio do tratamento mais benigno ao acusado, ${ }^{455}$.

Embora não de forma unânime, o STF manifestou-se recentemente nesse sentido, entendendo que se poderia aplicar causa de diminuição contida na Lei ${ }^{\circ}$ 11.343/2006 (Nova Lei de Drogas) sobre a pena cominada pela Lei $n^{\circ}$ 6.368/76 (Antiga Lei de Tóxicos). Confira-se:

"Ação Penal. Condenação. Pena. Privativa de Liberdade. Prisão. Causa
de diminuição prevista no art. 33 da Lei $n^{\circ} 11.343 / 2006$. Cálculo sobre a
pena cominada no art. 12, caput, da Lei $\mathrm{n}^{\circ} 6.368 / 76$, e já definida em
concreto. Admissibilidade. Criação jurisprudencial de terceira norma.
Não ocorrência. Nova valoração da conduta do chamado 'pequeno
traficante'. Retroatividade da lei mais benéfica. HC concedido. Voto
vencido da Min. Ellen Gracie, Relatora original. Inteligência do art.
$5^{\circ}, \mathrm{XL}$, da CF. A causa de diminuição de pena prevista no art. 33 da
Lei $\mathrm{n}^{\circ} 11.343 / 2006$, mais benigna, pode ser aplicada sobre a pena fixada
com base no disposto no art. 12 , caput, da Lei $\mathrm{n}^{\circ} 6.368 / 2006^{4456}$.

Parece-nos que, se os aspectos da lei nova e da lei revogada foram cindíveis, pode o Juiz combiná-las (por exemplo, aplicando nova causa de diminuição a pena constante da lei velha; não poderia, entretanto, e.g., tomar uma pena menor de reclusão e conferir-lhe natureza detentiva).

\subsubsection{As leis penais excepcionais e temporárias}

São exceções à retroatividade benigna as leis penais excepcionais e temporárias, criadas para reger uma situação determinada e transitória ou para viger durante um período pré-determinado (por exemplo, a lei que cria o tabelamento de preços para conter a inflação no país). Conforme dispõe o artigo $3^{\circ}$ do Código Penal, o fato praticado durante a vigência de leis excepcionais e temporárias é por elas regulado mesmo que cessem as circunstâncias que as determinaram ou que decorra seu período de vigência:

\footnotetext{
${ }^{455}$ NORONHA, Edgard Magalhães. op. cit., p. 78.

${ }^{456}$ STF, $2^{\text {a }}$ Turma, HC n 95435/RS, Rel. Min. Cezar Peluso, j. 21.10.2008, votação por maioria, vencida a Min. Ellen Gracie.
} 
"Art. $3^{\circ}$. A lei excepcional ou temporária, embora decorrido o período de sua duração ou cessadas as circunstâncias que a determinaram, aplica-se ao fato praticado durante a sua vigência"

Logo, mesmo que lhes sobrevenha uma lei mais benéfica, o fato praticado durante sua vigência continua por elas regulado. Como afirmam Celso Delmanto, Roberto Delmanto, Roberto Delmanto Junior e Fabio M. de Almeida Delmanto:

\begin{abstract}
"A regra da retroatividade benigna não é aplicável em casos de leis excepcionais ou temporárias. (...) São normas de natureza especial, claramente editadas para vigorar apenas em situações anormais ou durante tempo determinado. Tendo em vista a natureza especial dessas normas, editadas para vigorar apenas em situações anormais ou durante tempo determinado, o CP abre exceção, com relação a elas, à regra da retroatividade da lei posterior mais favorável. Como é óbvio, elas perderiam toda a sua força intimidativa, caso o agente já soubesse, de antemão, que, após cessada a anormalidade (no caso das leis excepcionais) ou findo o período de vigência (das leis temporárias), acabaria impune pela aplicação do princípio da retroatividade, ${ }^{, 457}$.
\end{abstract}

Como se vê, as leis excepcionais e temporárias são sempre ultrativas, projetando seus efeitos para período posterior ao fim de sua vigência.

\title{
6.2.3. As normas penais em branco
}

As normas penais em branco são aquelas cuja definição é complementada por outra norma (por exemplo a Lei de Drogas, a qual é complementada por portaria contendo lista das substâncias proibidas). Discute-se se a edição de norma complementadora mais favorável teria ou não aplicação retroativa.

Em regra, quando a norma que complementa o tipo é revogada, a questão deve ser tratada como abolitio criminis. Por exemplo, se durante processo por porte de determinada droga fosse editada nova portaria na qual aquela não constasse, o fato passaria a ser atípico, operando-se a extinção da punibilidade, com base no artigo 107, inciso III, do Código Penal.

\footnotetext{
${ }^{457}$ DELMANTO, Celso; DELMANTO, Roberto; DELMANTO JÚNIOR, Roberto; DELMANTO, Fabio M. de Almeida. Código Penal comentado. 7. ed. rev. atual. e ampl. Rio de Janeiro: Renovar, 2007. p. 26.
} 
No entanto, deve-se atentar para o fato de que as normas penais em branco muitas vezes são complementadas por outras de caráter excepcional (por exemplo, portaria que contenha o tabelamento de um determinado produto), caso em que sua revogação não beneficiará o agente, pelas razões expostas no item anterior.

Daí concluírem Julio Fabbrini Mirabete e Renato N. Fabbrini:

\begin{abstract}
“Assim, pode-se concluir que há de se fazer uma distinção: (a) se a norma penal em branco tem caráter excepcional ou temporário, aplica-se o art. $3^{\circ}$ do $\mathrm{CP}$, sendo a norma complementar ultrativa; (b) se, ao contrário, não tem ela o caráter temporário ou excepcional, aplica-se o art. $2^{\circ}$, parágrafo único, ocorrendo a abolitio criminis ${ }^{, 458}$.
\end{abstract}

Logo, podemos dizer que as normas penais em branco benéficas têm, em regra, efeito imediato e retroativo, salvo se forem excepcionais ou temporárias.

\title{
6.2.4. Tempo do crime
}

Às regras de direito penal intertemporal penal referidas alhures deve-se conjugar a de que se considera tempo do crime o momento da conduta, vez que o artigo $4^{\circ}$ do Código Penal adotou a teoria da atividade:

"Art. $4^{\circ}$. Considera-se praticado o crime no momento da ação ou omissão, ainda que outro seja o momento do resultado".

Logo, a regra é a de que se aplica a lei do tempo da conduta, salvo se lhe sobrevier norma penal mais benéfica.

Discutia-se, no entanto, qual seria a lei aplicável aos crimes continuado e permanente. Contudo, o STF fechou questão ao editar a Súmula no 711, segundo a qual "a lei penal mais grave aplica-se ao crime continuado ou ao crime permanente, se a sua vigência é anterior à cessação da continuidade ou da permanência". Logo, no caso de crime permanente, aplicase a lei vigente ao tempo do último ato de execução, ainda que mais severa; o mesmo ocorre com ao crime continuado, se ainda não cessada a continuidade delitiva.

\footnotetext{
${ }^{458}$ MIRABETE, Julio Fabbrini; FABBRINI, Renato N. op. cit., p. 53.
} 


\subsubsection{A lei processual penal}

Assim como no sistema geral de direito intertemporal, a lei processual penal possui efeito imediato, atingindo as relações em curso, mesmo que prejudique o réu. Esta a regra inscrita no artigo $2^{\circ}$ do Código de Processo Penal:

"Art. $2^{\circ}$. A lei processual penal aplicar-se-á desde logo, sem prejuízo da validade dos atos realizados sob a vigência da lei anterior".

Contudo, há exceções a esta regra. A primeira refere-se às leis que versem sobre prisão preventiva e fiança, as quais não terão aplicação quando prejudicarem o réu - nestes dois casos, garante-se ultratividade aos efeitos da lei revogada benéfica. Isto o que dispõe o artigo $2^{\circ}$ da Lei de Introdução ao Código de Processo Penal:

“Art. $2^{\circ}$. À prisão preventiva e à fiança aplicar-se-ão os dispositivos que forem mais favoráveis".

A segunda diz respeito a certas leis de natureza híbrida, que influenciam no processo-penal mas possuem conteúdo de direito material, devendo ser aplicadas como se lei penal o fossem (por exemplo, a lei que venha a exigir queixa a crime que antes era de ação penal pública incondicionada: de um lado, terá caráter processual pois influirá no processo, mas terá também natureza material pois a não-apresentação da queixa gera a extinção da punibilidade, que é tema de direito penal). A este respeito, discorrem Julio Fabbrini Mirabete e Renato N. Fabbrini:

"Existem, aliás, leis processuais que possuem carga penal, por influírem diretamente em institutos penais, como na fixação da pena, extinção da punibilidade etc. Essas normas mistas obedecem aos princípios da retroatividade da lei mais benigna e irretroatividade da lei mais severa, sob pena de infringência aos princípios constitucionais. É o que ocorre, por exemplo, com o art. 88 da Lei $n^{\circ}$ 9.099/95, que passou a exigir a representação no crime de lesões corporais leves e lesões culposas $(\ldots)^{, 459}$.

${ }^{459}$ MIRABETE, Julio Fabbrini; FABBRINI, Renato N. op. cit., p. 54. 
Logo, pode-se dizer que, em geral, as normas de direito processual penal seguem as regras comuns ao direito intertemporal - ou seja, aplica-se desde logo a lei nova, respeitados o direito adquirido, o ato jurídico perfeito e a coisa julgada. Excepcionalmente, porém, a lei processual penal será ultrativa (nos casos de fiança e prisão preventiva) ou retroativa (nos casos das normas processuais penais de conteúdo material).

\title{
6.3. Direito Intertemporal Tributário
}

Também no direito tributário, a retroatividade é expressamente vedada pela Constituição Federal. Dispõe o artigo 150, inciso III, alínea $a$ :

\begin{abstract}
"Art. 150. Sem prejuízo de outras garantias asseguradas ao contribuinte, é vedado à União, aos Estados, ao Distrito Federal e aos Municípios:

III - cobrar tributos:

a) em relação a fatos geradores ocorridos antes do início da vigência da lei que os houver instituído ou aumentado".
\end{abstract}

De acordo com este dispositivo constitucional, a lei tributária não se pode voltar para o passado, aplicando-se apenas aos fatos geradores posteriores ao início de sua vigência. Neste mesmo sentido dispõe o artigo 105 do Código Tributário Nacional:

“Art. 105. A legislação tributária aplica-se imediatamente aos fatos geradores futuros e aos pendentes, assim entendidos aqueles cuja ocorrência tenha tido início mas não esteja completa nos termos do art. $116^{, 460}$.

A esta regra somam-se as da anterioridade e da anterioridade nonagesimal, segundo as quais, salvo as expressas exceções constitucionais ${ }^{461}$, é proibido cobrar ou aumentar tributo no mesmo exercício financeiro e antes de noventa dias da publicação da lei que os haja

\footnotetext{
${ }^{460}$ Por "fatos geradores pendentes" devem se entender os fatos não completamente formados antes do início da lei nova e que só se verificam com a conjunção de elementos dependentes entre si (item 3.3.2.2).

${ }^{461}$ Artigo $150, \S 1^{\circ}$ : “A vedação do inciso III, $b$, não se aplica aos tributos previstos nos arts. 148, I, 153, I, II, IV e V; e 154, II; e a vedação do inciso III, $c$, não se aplica aos tributos previstos nos arts. 148, I, 153, I, II, III e IV; e 154, II, nem à fixação da base de cálculo dos impostos previstos nos arts. 155, III, e 156, I”.
} 
instituído ou aumentado, conforme dispõe o artigo 150, inciso III, alíneas $b$ e $c$, da Constituição Federal:

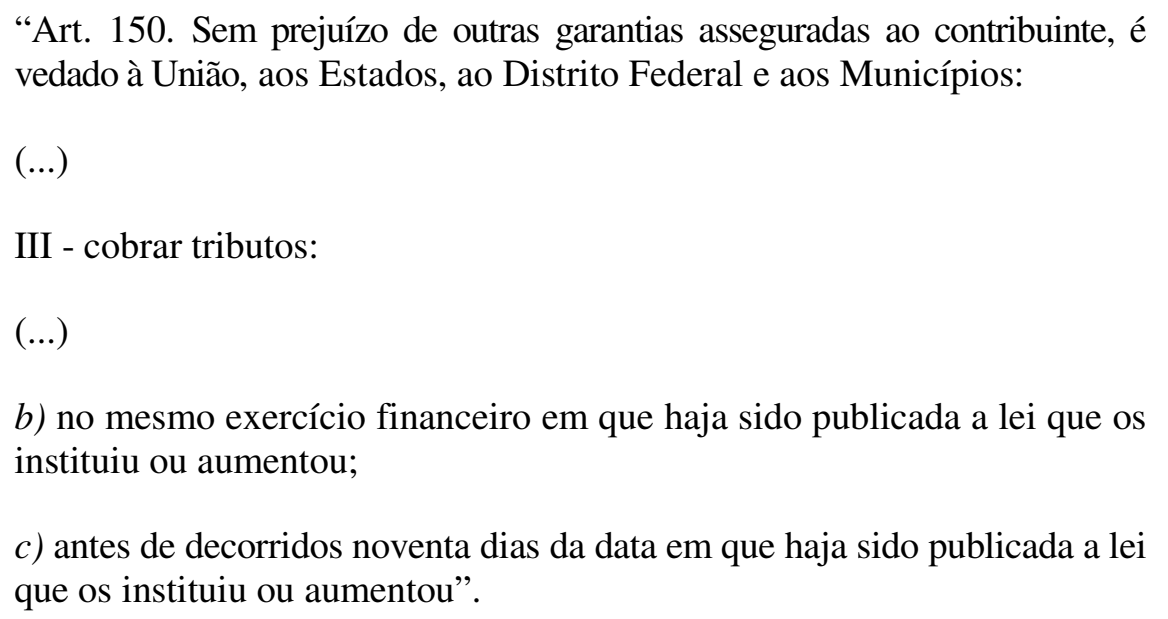

Sobre elas, comenta Regina Helena Costa:

“(...) visa evitar seja o contribuinte surpreendido mediante uma nova imposição fiscal ou a majoração de tributo já existente. Juntamente com os princípios da legalidade tributária e da irretroatividade da lei tributária - que traduz a impossibilidade de a lei fiscal alcançar fatos pretéritos (art. 150, III, $a, \mathrm{CF}$ ) -, representa uma das garantias mais expressivas do chamado 'Estatuto do Contribuinte", ${ }^{462}$.

Assim, no direito tributário a lei nova não se volta ao passado, mas se aplica desde logo aos fatos geradores posteriores ao início de sua vigência, ainda que pendentes, a menos que haja instituído ou aumentado tributo - hipótese em que, em regra, só será exigível no exercício financeiro seguinte e depois de noventa dias de sua publicação.

Vale mencionar, pouco importa que o lançamento tributário tenha ocorrido em momento posterior. Este - o lançamento tributário - reporta-se à data da ocorrência do fato gerador, e rege-se, em regra, pela lei vigente ao tempo de sua ocorrência, conforme dispõe o artigo 144, caput, do Código Tributário Nacional:

\footnotetext{
${ }^{462}$ in COSTA, Regina Helena. Código Tributário Nacional comentado: doutrina e jurisprudência, artigo por artigo, inclusivo ICMS e ISS. Coordenador Vladimir Passos de Freitas. 4. ed. rev. atual. e ampl. São Paulo: Ed. Revista dos Tribunais, 2007. p. 50.
} 
"Art. 144. O lançamento reporta-se à data da ocorrência do fato gerador da obrigação e rege-se pela lei então vigente, ainda que posteriormente modificada ou revogada".

Contudo, a lei tributária irá retroagir nas hipóteses expressamente previstas no artigo 106 do Código Tributário Nacional: (1) no caso de lei expressamente interpretativa e cuja aplicação não importe em imposição de penalidade; e (2) quando a lei nova deixe de aplicar ou amenize penalidade, desde que ( $a$ ) não implique não-pagamento de tributo; e ( $b$ ) não esteja acobertada por decisão judicial transitada em julgado. Como sempre laboram a benefício do contribuinte, tais hipóteses não se inserem na vedação contida no artigo 150, inciso III, alínea $a$, da Constituição Federal, o qual constitui limite ao poder de tributar e deve ser interpretado favoravelmente ao contribuinte.

Não se trata de retroatividade tão ampla quanto a do direito penal, pois não abrange os tributos (por exemplo, não retroage a lei que minora a alíquota de um determinado imposto) e não atinge as decisões judiciais transitadas em julgado. 


\section{SÉTIMA PARTE. CONCLUSÕES}

\section{Teoria Geral}

1. O objeto do direito intertemporal restringe-se à intertemporalidade conflitual, que se dá nos casos de sucessão entre normas de igual objeto e hierarquia. As regras de direito intertemporal não devem ser aplicadas quando houver intertemporalidade nãoconflitual, em que a lei nova não tem exatamente o mesmo objeto da lei revogada (item 2.1).

2. O estudo do direito intertemporal demanda a divisão dos fatos em passados, presentes, futuros e pendentes. Tomando-se a lei nova como referencial, os fatos serão passados, presentes e futuros conforme o sejam anteriores, concomitantes ou posteriores a ela. Os fatos pendentes são os que nascem sob uma determinada lei e continuam a produzir efeitos na vigência de outra que a tenha revogado (item 2.2).

3. O efeito retroativo se dá quando a lei nova atinge os fatos passados. Quando atinge os fatos pendentes, mas não os passados, há efeito imediato, e não retroativo. A lei que atinge direitos adquiridos não necessariamente é retroativa (item 2.3.1).

4. O efeito imediato ocorre quando a lei nova age para dela em diante. Denominamo-no imediato simples quando atinge apenas efeitos concomitantes ao início de vigência da lei nova e imediato qualificado quando age sobre os efeitos pendentes. A doutrina os trata, respectivamente, como prospectivo e retroprospectivo (item 2.3.2).

5. Há ultratividade quando, apesar do advento da lei nova, os efeitos da lei revogada continuam a regular alguns fatos, no futuro. O fenômeno pode se dar por disposição expressa da lei nova ou em razão da proteção do direito adquirido. A doutrina também o denomina de pós-atividade (item 2.3.3).

6. Em regra, a vigência e os efeitos da lei ocorrerão no mesmo momento, ou seja, no presente (efeito imediato), mas poderá o Legislador dispor em contrário, estipulando que efeitos nascidos no presente rejam fatos ocorridos no passado (retroatividade). Em qualquer caso, porém, o Juiz deverá garantir que os efeitos da lei revogada continuem a reger os direitos adquiridos sob o império da norma antiga, obstando os efeitos da lei nova (ultratividade). 
Retroatividade não significa que a lei tenha tido vigência no passado. Quer dizer que a lei nova projetou efeitos, no presente, para um tempo anterior ao início de sua vigência, o que é possível por ser uma proposição lógica do mundo do dever-ser, que pode estipular consequiências a fatos cuja existência não coincida com o seu período de vigência.

Ultratividade não significa que lei tenha continuado a viger depois de revogada. Quer dizer que, por disposição da lei nova ou em razão da proteção do direito adquirido, seus efeitos continuaram a reger uma determinada categoria de fatos, projetando-se para um tempo ulterior à sua revogação (item 2.3).

7. O princípio da irretroatividade tem como finalidade garantir proteção ao direito adquirido, conferindo ultratividade aos efeitos da lei revogada. Ele limita todos os possíveis efeitos da lei nova e não somente o retroativo, de modo que não se sustenta a dicotomia irretroatividade versus retroatividade (item 2.4).

8. O sistema de direito intertemporal brasileiro agasalha tanto a regra do efeito imediato (artigo $6^{\circ}$, caput, da Lei de Introdução ao Código Civil) como a da proteção dos direitos adquiridos (artigo $5^{\circ}$, inciso XXXVI, da Constituição Federal, e $6^{\circ}$, $\S 2^{\circ}$, da Lei de Introdução ao Código Civil). Atribuiu-se ao direito adquirido a tarefa de limitar o efeito imediato da lei nova (item 2.5).

9. O direito intertemporal brasileiro possui características próprias, não podendo o intérprete utilizar isoladamente as teorias de Carlos Francesco Gabba (item 1.2.1) ou de Paul Roubier (1.2.2). Por razões históricas, houve uma simbiose entre uma e outra teoria (item 1.3).

O direito intertemporal brasileiro difere dos sistemas de direito intertemporal estrangeiros, razão pela qual não devemos importar regras alienígenas.

A teoria dos níveis de retroatividade não tem aplicação no direito intertemporal brasileiro, pois (a) ao criar os efeitos retroativo médio e mínimo, acaba por sugerir uma vedação, inexistente, ao efeito imediato da lei nova; e $(b)$ ao não obstar os efeitos retroativo médio e mínimo, acaba por vulnerar a proteção do direito adquirido (item 1.4.1).

A teoria dos fatos consumados se amolda apenas em parte ao direito intertemporal brasileiro. A máxima tempus regit factum não deve ser aplicada sem ressalvas, pois a lei 
nova pode atingir fatos passados e pendentes desde que não fira direitos adquiridos (item 1.4.2).

10. A Constituições de 1824 e 1891 proibiam a retroatividade da lei. As Constituições de 1934, 1946, 1967 e 1988 não proíbem a retroatividade da lei, mas garantem a proteção do direito adquirido. Apenas a Constituição de 1937 deixou de prever regra de direito intertemporal (item 2.5.1).

11. A Lei de Introdução ao Código Civil possuiu 3 redações diferentes. O texto de 1916 referia-se à proteção do direito adquirido mas não à regra do efeito imediato. O texto de 1942 referia-se somente à regra do efeito imediato, sem aludir à proteção do direito adquirido. Já o texto de 1957, que perdura até hoje, albergou tanto a regra do efeito imediato como a da proteção do direito adquirido (item 2.5.2).

12. Três foram as iniciativas de alteração da atual Lei de Introdução ao Código Civil, Projetos de Lei no 264/84, 4.905/95 e 243/2002, os dois últimos ainda em trâmite. Sugerimos a aprovação do Projeto de Lei $\mathrm{n}^{\circ} 4.905 / 95$, o qual carreia excelente conceito de direito adquirido, delimita com precisão o efeito imediato e prevê salutar regra de proporcionalidade para os casos de alteração de prazos (item 2.5.3).

13. A regra da proteção do direito adquirido vincula a Administração, o Juiz e o Legislador, inclusive o Constituinte Reformador. A regra do efeito imediato vincula apenas a Administração e o Juiz, podendo o Legislador prescrever leis retroativas, desde que não firam o direito adquirido, o ato jurídico perfeito e a coisa julgada (item 2.6).

14. O conceito de direito adquirido tem natureza infraconstitucional. A Constituição Federal protege o direito adquirido, enquanto a lei determina como e quando se dá a aquisição (item 3.1).

15. Conceituamos direito adquirido como aquele que, ao tempo da lei revogada, estava integrado ao patrimônio ou pendente de termo ou condição suspensiva.

Com a menção a "lei revogada", indicamos que a expressão só deverá ser considerada em caso de sucessão de leis; com a alusão a "patrimônio", garantimos que se está diante de direito efetivamente adquirido, e não de mera faculdade jurídica; ao nos referirmos a "termo ou condição", abrangemos direitos que a rigor ainda não fariam parte do patrimônio, mas 
que devem ser considerados adquiridos em razão de equiparação legal, dos artigos 131 do Código Civil de 2002 e $6^{\circ}, \S 2^{\circ}$, da Lei de Introdução ao Código Civil (item 3.2).

16. Como o direito intertemporal brasileiro proíbe não a retroatividade mas a ofensa a direitos adquiridos, é da maior importância determinar quando o direito passou a integrar o patrimônio do sujeito, a fim de verificar se a aquisição se deu antes ou depois do advento da lei nova. Para tanto, deve-se empreender estudo dos modos de aquisição dos direitos, que podem ser de aquisição simples ou complexa (item 3.3).

17. Os direitos de aquisição simples são os que passam ao patrimônio em um momento único e determinado. Para se verificar se está protegido contra a lei nova, basta tomar-se esta como referência e verificar se lhe é anterior ou posterior. Caso seja anterior, o direito não poderá ser atingido pela lei nova, mesmo que se tenha prolongado no tempo como no caso de contrato de prestações sucessivas (item 3.3.1).

18. A rigor, os direitos a termo e sob condição suspensiva são de aquisição complexa, pois dependem da conjunção ato jurídico + evento futuro para passarem ao patrimônio do titular. Contudo, os artigos 131 do Código Civil de 2002 e $6^{\circ}$, § $2^{\circ}$, da Lei de Introdução ao Código Civil, equiparam-nos a direitos adquiridos, razão pela qual deverão ser tratados como de aquisição simples (itens 3.3.1.1 e 3.3.1.2).

19. Dividimos os direitos de aquisição complexa em direitos de aquisição por elementos autônomos e direitos de aquisição por elementos dependentes (item 3.3.2).

20. Os direitos de aquisição por elementos autônomos são aqueles cujas partes constituem direitos individualizáveis. Há direito adquirido com relação a cada fato aquisitivo que se tiver completado antes do advento da lei nova (item 3.3.2.1).

21. Os direitos de aquisição por elementos dependentes são aqueles cujas partes só constituem direito quando consideradas em conjunto. Só há direito se verificados todos os elementos necessários à sua aquisição (item 3.3.2.2).

22. Nos casos de alteração do prazo para aquisição de um direito, a lei nova não pode desconsiderar a significação jurídica que o prazo já transcorrido tinha para o sistema anterior. Para se obter esta significação, deve-se calcular qual a relação entre o tempo transcorrido e o prazo da lei revogada (relação $=$ tempo transcorrido $\div$ prazo da lei revogada), multiplicando-se tal quociente pelo prazo da lei nova (significação jurídica $=$ relação $\mathrm{x}$ 
prazo da lei nova). Com o resultado obtido, calcula-se o tempo que ainda falta por cumprir (item 3.3.3).

23. $\mathrm{O}$ ato jurídico perfeito e a coisa julgada são figuras que se assemelham e possuem a mesma proteção conferida ao direito adquirido (item 3.4).

24. Ato jurídico perfeito é aquele cujos efeitos já se operaram e sobre o qual nada mais há a reclamar (item 3.4.1).

25. Coisa julgada é o atributo que torna imutável e irrecorrível a sentença de mérito (item 3.4.2).

26. Expectativas de direito, faculdades jurídicas e instituições jurídicas são figuras que se assemelham mas não possuem a mesma proteção conferida ao direito adquirido (item $3.5)$.

27. Expectativa de direito é um vir-a-ser-direito independente da vontade daquele que espera. A lei nova atinge as expectativas pois estas não possuem conteúdo patrimonial (item 3.5.1).

28. Faculdade jurídica é um vir-a-ser-direito dependente da vontade daquele a que se faculta. A lei nova atinge as faculdades não exercidas pois não existe direito adquirido ao direito objetivo (item 3.5.2).

29. Instituição jurídica é uma relação-tipo abstrata criada por lei. A lei que as extingue atinge direitos adquiridos, pois o direito intertemporal não poderia impedir a aplicação de certas normas jurídicas, o que ocorreria se não pudesse dar fim a relações-tipo ou a direitos perpétuos que não mais se amoldam às necessidades sociais. Trata-se de exceção (item 3.5.3).

30. Historicamente, o princípio da irretroatividade nunca foi absoluto (item 4.1).

31. Ao buscar limites à proteção do direito adquirido, o intérprete não se deve valer da dicotomia direito adquirido versus ordem pública, pois (a) como é protegido constitucionalmente, o Legislador não pode prescrever normas que ofendam o direito adquirido, mesmo que de ordem pública; e $(b)$ o direito adquirido e a ordem pública erigemse sobre os mesmos valores, não podendo ser contrapostos pelo Juiz (item 4.2.1). 
32. Também não devem ser utilizadas, como critério apriorístico de limitação da proteção do direito adquirido, a teoria da imprevisão e a ponderação de princípios.

A teoria da imprevisão só poderá ser utilizada como critério limitador se, concomitantemente, estiverem presentes os seguintes requisitos: (a) a existência de um negócio comutativo; (b) a norma como um fator imprevisível e que altere radicalmente as condições em que tiver sido entabulado o negócio; $(c)$ a ocorrência de onerosidade excessiva para uma das partes, causada diretamente pelo advento da nova norma; e $(d)$ a existência de vantagem à outra parte. Não será propriamente um critério limitador do direito adquirido, mas um estabilizador de contratos, aplicável somente a direitos adquiridos em razão de relações negociais.

A ponderação de princípios não deve ser utilizada, pois, embora válida e aceita pelo STF, a proteção do direito adquirido está assentada no cânone hermenêutico da segurança jurídica, do qual os demais princípios não se podem afastar (item 4.2.2).

33. Um paralelo com as teorias de relativização da coisa julgada sugere que, assim como esta não poderia ser utilizada para acobertar sentenças inexistentes, o direito intertemporal não poderia agasalhar atos imperfeitos e direitos aparentes.

A favor dessa tese, o fato de que, por não ter caráter processual, não se aplicam ao direito adquirido as mesmas críticas que poderiam ser tecidas à relativização da coisa julgada (item 4.2.3).

34. Ao invés de contrapor o direito adquirido à ordem pública, realizando uma ponderação valorativa posterior à formação do direito, o Juiz deverá ponderar na origem (no nascimento do direito), perscrutando se, levados em conta os princípios que informam o sistema jurídico, o direito havia se formado ou era meramente aparente, caso em que deverá aplicar a lei nova independentemente de sua natureza.

Muitas leis de ordem pública vêm apenas explicitar princípios que já estavam presentes no sistema jurídico, os quais impediam a aquisição do direito mesmo à míngua de lei em contrário. A aquisição de direitos deve considerar todo o sistema jurídico e não apenas a letra da lei, que muitas vezes tolera abusos que os princípios combatem.

O ato abusivo não dá azo a direito adquirido, pois o sistema jurídico não poderia permitir a intangibilidade de uma prática ilícita e contrária aos seus fundamentos, mesmo que a 
lei não a condenasse. O Juiz deverá decretar a nulidade do ato, tenha ele ocorrido antes ou depois de lei que o venha coibir expressamente - não poderá a parte alegar direito adquirido para obstar a aplicação da lei nova, proibitiva, tendo em vista que o ato já poderia ser considerado um não-direito antes de seu advento.

Por isto afirmamos que o Juiz deverá realizar uma ponderação na origem, analisando se a lei nova realmente contraria direito adquirido ou se este já não poderia ser decretado nulo desde o seu nascimento. O Juiz não pode permitir que o direito intertemporal seja utilizado para agasalhar atos imperfeitos e direitos aparentes, blindando negócios inválidos que não têm e não devem receber proteção contra a lei nova que os expressamente proíba (item 4.2.4).

\section{Parte prática}

\section{a. Parte Geral}

35. Com a alteração da maioridade, de 21 para 18 anos, as pessoas com mais de 18 anos em 11 de janeiro de 2003 passaram a ser capazes, com o que cessaram os deveres decorrentes da incapacidade civil. Contudo, não se alteraram os deveres decorrentes não da incapacidade mas, sim, da idade (item 5.1.1).

36. Embora a validade dos negócios jurídicos deva ser aferida, em regra, de acordo com a lei vigente ao tempo de sua celebração, os artigos 156 e 157 do Código Civil de 2002 podem ser aplicados a relações anteriores ao seu advento, tendo em vista que o estado de perigo e a lesão já poderiam ser reconhecidos pelo Judiciário antes de 11 de janeiro de 2003.

Os negócios jurídicos eivados dos vícios do estado de perigo e da lesão são contrários aos princípios informadores do sistema jurídico, e não têm, pois, condão de configurar ato jurídico perfeito ou direito adquirido (item 5.1.2).

37. Embora tenha aplicação imediata, a lei que altera prazos prescricionais não pode desconsiderar a significação jurídica que o tempo escoado tinha para o sistema anterior. Por essa razão, o intérprete deverá aplicar regra de proporcionalidade (item 5.1.3). 
38. O artigo 2.028 só deve ser aplicado quando o Código Civil de 2002 houver reduzido um prazo do Código Civil de 1916. Por sua vez, só se poderá falar em redução quando o prazo posterior tiver a mesma natureza do anterior, pois, do contrário, estar-se-á diante de direito novo, de aplicação imediata.

No caso dos prazos de prescrição, o artigo 2.028 só terá aplicação se houver choque prazo geral x prazo geral (artigo 205 do Código Civil de 2002 x artigo 177 do Código Civil de 1916) ou prazo especial x prazo especial (artigo 206 do Código Civil de 2002 x artigo 178 do Código Civil de 1916). Se o Código Civil de 2002 tiver disciplinado como prazo especial matéria que antes era tratada na regra geral do Código Civil de 1916 (artigo 206 do Código Civil de 2002 x artigo 177 do Código Civil de 1916), não terá havido redução mas inovação, que se impõe a todas as relações em curso, de forma imediata (a partir de 11 de janeiro de 2003), independentemente do tempo já ecoado sob a égide da lei anterior.

Caso conclua pela aplicação do artigo 2.028, o cômputo do prazo novo deverá ser feito pela aplicação de regra de proporcionalidade (item 5.1.4).

39. O artigo 221 do Código Civil de 2002 não conflita com o artigo 585, inciso II, do Código de Processo Civil, mantendo-se a exigência de duas testemunhas para que o contrato seja considerado título executivo (item 5.1.5).

\section{b. Direito das Obrigações}

40. Os juros de mora, quando não convencionados, serão de $0,5 \%$ ao mês até 11 de janeiro de 2003 e de $1 \%$ ao mês desta data em diante, em atenção à regra do efeito imediato e a uma interpretação combinada dos artigos 406, do Código Civil de 2002, e 161, § $1^{\text {o }}$, do Código Tributário Nacional (item 5.2.1).

41. A partir de 11 de janeiro de 2003, as partes poderão convencionar juros moratórios ou compensatórios de até $24 \%$ ao ano, desde que não estejam diante de contrato de mútuo. Caso sejam parte em contrato de mútuo, estarão limitadas à taxa de $12 \%$ ao ano (item 5.2.2). 
42. O artigo 405 do Código Civil de 2002 não altera o dies a quo para contagem dos juros de mora. O dispositivo só terá aplicação nos casos em que for necessária interpelação e para os quais não haja regra expressa à constituição da mora.

Com a redação dada ao artigo 398, a mora nos atos ilícitos deve ser contada sempre da data do fato, não importando tratar-se de ilícito contratual ou extracontratual. A Súmula $n^{\circ} 54$ do STJ é incompatível com o Código Civil de 2002, não merecendo aplicação a partir de 11 de janeiro de 2003, mesmo para os ilícitos perpetrados em momento anterior a esta data (item 5.2.3).

43. Cláusula penal aposta em convenção de condomínio anterior a 11 de janeiro de 2003 , de até $20 \%$, não poderá ser limitada a $2 \%$ pelo novel artigo $1.336, \S 1^{\circ}$, do Código Civil de 2002, o qual só terá aplicabilidade depois do início de sua vigência. Embora a indenização convencionada só vá nascer com o inadimplemento, a estipulação que lhe dá origem deve ser protegida contra a incidência da lei nova, pois gera um direito de aquisição por elementos autônomos, o qual não pode ser atingido em suas partes perfeitas e individualizáveis (item 5.2.4).

\section{c. Contratos}

44. Conjugando as regras do efeito imediato e da proteção ao direito adquirido, o artigo 2.035, caput, está a dispor que, como qualquer outra lei, o Código Civil de 2002 deverá atuar de forma imediata, do início de sua vigência em diante, preservando os fatos passados e incidindo sobre todas as relações futuras e em curso, desde que não ofenda direito adquirido, ato jurídico perfeito ou coisa julgada - donde $(a)$ os atos e negócios jurídicos passados que tenham produzido todos os seus efeitos sob a égide da lei anterior não serão atingidos pelo Código Civil de 2002, em respeito ao ato jurídico perfeito; (b) pela mesma razão, a existência e a validade dos atos e negócios jurídicos constituídos antes de 11 de janeiro de 2003 não sofrerão os efeitos do Código Civil de 2002; (c) a contrario sensu, os atos e negócios jurídicos em formação, que não tenham sido concluídos antes de 11 de janeiro de 2003, deverão ser atingidos pelo Código Civil de 2002; (d) os atos e negócios jurídicos pendentes, que não tenham produzido todos os seus efeitos sob a égide da lei anterior, deverão ser cindidos em duas partes: (d.1) os efeitos anteriores a 11 de janeiro de 2003 não serão atingidos pelo Código Civil de 2003; (d.2) os efeitos posteriores a 11 de janeiro de 
2003 deverão ser atingidos pelo Código Civil de 2002, salvo se constituírem direito adquirido (item 5.3.1).

45. O artigo 2.035, parágrafo único, indica que não há aquisição de direito contra preceitos de ordem pública, daí inexistindo óbice a que se aplique, de forma imediata, o Código Civil de 2002.

Se o negócio jurídico não observar a boa-fé objetiva ou a função social do contrato, a parte a quem aproveita não poderá invocar direito adquirido, porque tal ato já poderia ser considerado um não-direito antes dos artigos 421 e 422 do Código Civil de 2002. O ato contrário à boa-fé objetiva ou à função social tem apenas aparência de direito, não merecendo a mesma proteção conferida ao direito efetivamente adquirido (item 5.3.2).

46. Desde que presentes seus pressupostos, a teoria da imprevisão pode ser aplicada, pelo Juiz, a contratos e prestações anteriores a 11 de janeiro de 2003, pois os princípios que a fundamentam já estavam presentes no sistema jurídico antes do Código Civil de 2002 (item 5.3.3).

47. O artigo 835 do Código Civil de 2002 dispõe sobre faculdade jurídica, a qual deve ser analisada sob a ótica da lei nova, mesmo que atinja relações em curso. Por essa razão, a partir de 11 de janeiro de 2003 o fiador poderá exonerar-se da obrigação por mera notificação extrajudicial.

O entendimento também vale para as fianças locatícias. O artigo 2.036 não se aplica ao caso, pois não existe conflito entre o Código Civil de 2002 e a Lei $n^{\circ}$ 8.245/91 (item 5.3.4).

\section{d. Responsabilidade Civil}

48. Nas questões de responsabilidade civil, aplica-se a lei vigente ao tempo da prática do ilícito, pois não poderia a lei nova proibir ato já praticado, sob pena de ofensa ao princípio da legalidade. Contudo, se já pudesse ser considerado ilícito mesmo antes de lei a respeito, por desconsiderar princípios que informam o sistema jurídico, a norma nova deverá atingir fatos ocorridos no passado. É o caso, por exemplo, do artigo 187 do Código Civil de 2002, que poderá ser aplicado retroativamente porque apenas enunciou algo que 
o sistema jurídico já prescrevia, que "também comete ato ilícito o titular de um direito que, ao exercê-lo, excede manifestamente os limites impostos pelo seu fim econômico ou social, pela boa-fé ou pelos bons costumes" (item 5.4).

\section{e. Direito das Coisas}

49. As questões intertemporais relacionadas aos efeitos dos direitos reais comportamse, em geral, como as instituições jurídicas, não respeitando direitos adquiridos.

As faculdades decorrentes dos direitos reais não têm proteção contra a lei nova, tendo em vista que não existe direito adquirido ao direito objetivo (item 5.5).

50. O Código Civil de 2002 resguarda em parte os direitos dos senhorios e enfiteutas, prevendo fórmula que retira, aos poucos, o interesse econômico da enfiteuse, levando-a à morte por inanição.

Contudo, isso não autorizaria os senhorios a pleitearem direitos não contidos no artigo 2.038, caput. A lei que extingue instituições jurídicas ou direitos perpétuos tem efeito imediato e retroativo, inclusive sobre direitos adquiridos. Se o artigo 2.038, caput, preservou alguns desses direitos, o fez por uma questão de política legislativa, que não autoriza o senhorio a reclamar outros direitos, como por exemplo o laudêmio sobre o valor do negócio todo.

Também não poderia o enfiteuta pleitear direito adquirido à constituição de subenfiteuses, proibidas pelo artigo $2.038, \S 2^{\circ}$, inciso II, porque essa possibilidade constituía mera faculdade jurídica, que sofre incidência da lei nova (item 5.5.1).

51. Aplica-se o artigo 2.028 quando o Código Civil de 2002 houver reduzido um prazo de usucapião. Contudo, só haverá redução quando o prazo posterior tiver a mesma natureza do anterior, pois senão se estará diante de direito novo, de aplicação imediata. Assim, o artigo 2.028 só deverá ser aplicado se houver choque prazo de usucapião ordinária x prazo de usucapião ordinária (artigo 1.242 do Código Civil de 2002 x artigo 551 do Código Civil de 1916) ou prazo de usucapião extraordinária x prazo de usucapião extraordinária (artigo 1.238 do Código Civil de 2002 x artigo 550 do Código Civil de 
1916). O artigo 2.028 não terá aplicação quando se estiver diante das novas espécies de usucapião, as quais constituem direito novo e possuem aplicação imediata.

Aplica-se o artigo 2.029 aos prazos menores da usucapião ordinária ou extraordinária, de 5 e 10 anos, respectivamente (artigos 1.238, parágrafo único, e 1.242, parágrafo único), acrescendo-se-os de 2 anos até 11 de janeiro de 2005, qualquer que seja o tempo transcorrido - portanto, não se aplicando, também nesta hipótese, o artigo 2.028. Até 11 de janeiro de 2005 tais prazos serão de 7 e 12 anos, e depois dessa data voltarão a ser de 5 e 10 anos.

Tanto no caso do artigo 2.028 como no do artigo 2.029, o cômputo dos novos prazos deverá ser feito pela regra de proporcionalidade (item 5.5.2).

52. Até 11 de janeiro de 2005, o prazo da desapropriação judicial, do artigo 1.228, $\S 4^{\circ}$, será de 7 anos, voltando a ser de 5 depois dessa data. Em qualquer caso, por se tratar de direito novo, o prazo deverá ser contado a partir de 11 de janeiro de 2003 (item 5.5.3).

\section{f. Direito de Família}

53. Adotado um determinado regime de bens, surge para os cônjuges uma série de direitos, os quais são regulados, em regra, pela lei vigente ao tempo do casamento. Contudo, não é exato supor que qualquer questão ligada ao regime de bens esteja ao abrigo da lei nova, dado que este gera para os cônjuges não só direitos mas também faculdades, proibições e deveres, os quais não possuem a mesma proteção conferida ao direito adquirido.

Assim, por exemplo, a partir de 11 de janeiro de 2003 um cônjuge não poderá, salvo no regime da separação de bens, prestar fiança ou aval sem o consentimento do outro, conforme prescreve o artigo 1.647, inciso III, do Código Civil de 2002, mesmo que se tenha casado na vigência do Código Civil de 1916, que não o exigia; o cônjuge casado no regime da separação de bens antes do Código Civil de 2002 poderá alienar livremente seus bens imóveis, sem autorização do outro, nos termos do artigo 1.687 do Código Civil de 2002, embora o artigo 276 do Código Civil de 1916 dispusesse em contrário (item 5.6.1). 
54. O artigo 1.639, § $2^{\circ}$, aplica-se aos casamentos celebrados antes de 11 de janeiro de 2003, pois se trata de mera faculdade jurídica. O artigo 2.039 tem em vista garantir segurança jurídica, e não proibir que os cônjuges possam alterar o regime anteriormente escolhido, por vontade própria (item 5.6.2).

55. O Código Civil de 2002 se aplica ao regime patrimonial das uniões estáveis iniciadas antes de 11 de janeiro de 2003. A alteração não implica ofensa a direitos adquiridos, pois a titularidade dos bens é um direito do casal, e não somente do companheiro que os registrou - tanto que, se quisessem, os companheiros poderiam ressalvar a aplicação da nova lei, por meio de contrato escrito, atribuindo os bens a apenas um deles.

Como a união estável é relação continuativa, seus efeitos sujeitam-se às alterações legislativas que ocorrerem em seu curso. Se a lei nova atribui ao convivente o status de companheiro, não poderia fazê-lo pela metade, excluindo os aspectos patrimoniais companheiro nas lutas e sócio no patrimônio. O patrimônio do casal é um direito adquirido do casal, mesmo que esta condição só tenha sido reconhecida depois da aquisição do bem (item 5.6.3).

56. As questões pessoais do direito de família sofrem a incidência imediata da lei nova. A lei nova regulará, do início de sua vigência em diante, o poder familiar, a relação pessoal entre os cônjuges, os deveres e direitos de cada consorte, os efeitos da adoção já realizada, a tutela e a curatela, o direito a alimentos, a administração dos bens dos filhos e as relações entre os genitores e a prole - salvo, neste último caso, se houver acordo dispondo em sentido contrário (item 5.6.4).

57. O Código Civil de 2002 não veio proibir o casamento entre colaterais. O artigo 1.521 , inciso IV, não conflita com o Decreto-Lei $n^{\circ} 3.200 / 41$, que é regra especial (item 5.6.5).

58. Os contratos sociais das sociedades constituídas antes do Código Civil de 2002, por cônjuges casados nos regimes da comunhão total ou no da separação obrigatória, configuram ato jurídico perfeito, o qual está ao abrigo de proibições impostas pela lei nova - é ato que, quando realizado, respeitou todas as formalidades que lhe eram impostas, exaurindo seus efeitos em um tempo passado. Por sua vez, as possibilidades de contratar entre si e de casar nos regimes da comunhão total ou no da separação de bens eram 
faculdades que, se não exercidas antes do Código Civil de 2002, pertenciam apenas ao direito objetivo, e não poderiam, pois, ser reclamadas como direito adquirido dos sócios ou dos cônjuges unidos antes de 11 de janeiro de 2003 (item 5.6.6).

\section{g. Direito das Sucessões}

59. Conjugando-se o princípio de saisine com a regra do efeito imediato, tem-se que a lei nova, posterior à morte, não poderia regular a transmissão dos bens do de cujus, atribuindo a determinada pessoa qualidade de herdeiro que não possuía ao tempo do falecimento. Como a herança se transmite com o falecimento, a lei nova estaria dispondo para trás, desautorizadamente, atribuindo conseqüências a hipótese anterior ao início de sua vigência. Nisto repousa a regra do artigo 1.787 do Código Civil e também a disposição transitória contida no artigo 2.041 do Código Civil (item 5.7).

60. Só se aplica a ordem de vocação hereditária constante do artigo 1.829 do Código Civil às sucessões abertas depois de 11 de janeiro de 2003. Às sucessões abertas antes dessa data, aplicam-se as disposições constantes do artigo 1.603 Código Civil de 1916 (item 5.7.1).

61. Aplica-se à sucessão do companheiro a lei vigente ao tempo da morte do autor da herança, não importando quando se tenha iniciado a união estável. Importa apenas que os companheiros vivessem em união estável de acordo com a lei vigente ao tempo da abertura da sucessão.

Até o advento da Lei $n^{\circ} 8.971 / 94$, o companheiro nada herdaria; a partir da Lei $n^{\circ} 8.971 / 94$ e até a Lei $n^{\circ} 9.278 / 96$, o companheiro herdaria, de acordo com os ditames da Lei $n^{\circ} 8.971 / 94$, se, ao tempo da abertura da sucessão, preenchesse os requisitos impostos pelo artigo $1^{\circ}$ da referida lei; da Lei $n^{\circ}$ 9.278/96 até o início da vigência do Código Civil de 2002, o companheiro herdaria, de acordo com a Lei $\mathrm{n}^{\circ}$ 9.278/96, se, quando morto o de cujus, estivessem presentes as condições previstas nesta norma, artigo $1^{\circ}$, para configuração da união estável; do início da vigência do Código Civil de 2002 em diante, o companheiro herdará, de acordo com o disposto no artigo 1.790, se preencher os requisitos do artigo 1.723 (item 5.7.2.1). 
62. Com o artigo 1.790, o companheiro deixou de ter direito real de habitação, pois (a) ao tratar inteiramente da matéria, o Código Civil de 2002 revogou globalmente a Lei $\mathrm{n}^{\circ}$ 9.278/96, pondo fim a todas as disposições que não hajam sido repetidas pela nova lei civil, inclusive o artigo $7^{\circ}$, parágrafo único. O Código Civil de 2002 deu novo tratamento a toda a matéria, e não apenas aos artigos que com ele fossem incompatíveis; $(b)$ não seria possível uma interpretação analógica do artigo 1.831 do Código Civil, pois não se está diante de lacuna. Tudo indica que o Legislador pretendeu deixar de conferir direito real de habitação ao companheiro sobrevivente (item 5.7.2.2).

63. Caso o intérprete entenda que o artigo 1.790 do Código Civil é inconstitucional, o Código Civil de 2002 não teria revogado globalmente as Leis $n^{\circ}$ 8.971/94 e 9.278/96, que teriam continuado a reger a sucessão do companheiro (item 5.7.2.3).

64. Os problemas de direito intertemporal relacionados à sucessão testamentária podem ser resolvidos da seguinte maneira: aplica-se a lei do tempo da elaboração do testamento ao que disser respeito à sua forma e a lei vigente na abertura da sucessão ao que se referir a seu conteúdo. Essa fórmula reside na lógica de que a lei nova não se pode voltar sobre ato jurídico que se perfez na vigência da lei anterior, da confecção do testamento, assim como a lei antiga não poderia regular direito que só viria a nascer na vigência da lei nova, depois da abertura da sucessão. A forma do testamento está perfeita no passado, enquanto seu conteúdo só se tornará direito depois da morte do testador (item 5.7.3).

65. As questões atinentes à forma do testamento são as intrinsecamente ligadas ao ato, ou seja, as que dizem respeito ao testamento em si e não aos direitos decorrentes da sucessão testamentária (item 5.7.3.1).

66. As questões atinentes ao conteúdo do testamento são as que estão ligadas aos direitos dele decorrentes e à legitimação para adquiri-los (item 5.7.3.2).

67. O artigo 2.042 é regra transitória segundo a qual a necessidade de justificação das cláusulas restritivas só se aplica às sucessões abertas depois de um ano do início de sua vigência, ainda que o testamento tenha sido confeccionado na vigência do Código Civil de 1916. Durante este prazo, poderá o testador aditar o testamento. Trata-se de um caso de ultratividade propriamente dita (item 5.7.3.3). 
68. A sentença de vacância é meramente declaratória de um direito adquirido desde o momento da abertura da sucessão. Nesse contexto, há de se aplicar à herança vacante a lei vigente ao tempo da morte, em respeito ao princípio da saisine e ao artigo 1.784 do Código Civil. Por exemplo, a Lei $n^{\circ} 8.049 / 90$ não se aplica às sucessões abertas antes de seu advento, mesmo que a herança só tenha sido declarada vacante depois (item 5.7.4).

69. Observados os princípios da anterioridade e da anterioridade nonagesimal, quando aplicáveis, as questões tributárias relacionadas à sucessão causa mortis regem-se pelas mesmas regras delineadas para os direitos de aquisição simples, tendo em vista que seu fato gerador dá azo a direitos adquiridos em um momento único - direito de o contribuinte pagar um determinado valor, sem aumentos, e do Fisco de recebê-lo, sem reduções (item 5.7.5).

\section{Sistemas Especiais de Direito Intertemporal}

70. O direito intertemporal brasileiro possui um sistema geral que resolve os conflitos de lei no tempo em qualquer área da atividade jurídica. Contudo, o direito penal e o direito tributário possuem um sistema próprio de direito intertemporal, no qual a retroatividade da lei nova é expressamente proibida quando desfavorável, e necessária - não só admitida como determinada - quando favorável ao réu ou ao contribuinte.

Tanto em um como em outro, o princípio da irretroatividade ganha um significado próprio, de apriorística não-retroatividade e de proibição ao efeito imediato, quando na teoria geral do direito intertemporal este princípio se materializa na proteção do direito adquirido, cuja existência deve ser analisada em cada caso concreto (item 6.1).

\section{a. Direito Intertemporal Penal}

71. Como consequiência do princípio da reserva legal, a lei penal jamais poderá retroagir para prejudicar o réu. Contudo, a lei penal benigna será sempre ultrativa, de efeito imediato e retroativa, projetando efeitos para depois de sua revogação e aplicando-se aos fatos pendentes e passados, mesmo que já definitivamente julgados (item 6.2). 
72. A abolitio criminis é a lei que deixa de considerar crime um fato antes delituoso. O artigo 107, inciso III, do Código Penal, trata-a como causa de extinção da punibilidade, que dá cabo tanto à pretensão punitiva (poder de instaurar a ação penal) como à pretensão executória (dever de exigir o cumprimento da pena). Em conseqüência, a abolitio criminis põe fim a todos os efeitos penais da condenação, mesmo que ocorra depois do trânsito em julgado da sentença penal condenatória. Só não apaga os efeitos civis, tendo em vista que o dever de indenizar decorre do ilícito civil e não do caráter criminoso do evento danoso.

A novatio legis in mellius é toda lei que beneficia o réu sem abolir o crime (por exemplo, a lei que diminui a pena, permite a progressão de regimes, diminui prazos de prescrição etc). Também tem efeito imediato e retroativo, atingindo as situações pendentes e passadas, mesmo que definitivamente julgadas.

Discute-se se seria possível a combinação de aspectos benéficos da lei nova e da lei revogada. Em desfavor, argumenta-se que, ao combinar a lei revogadora com a lei revogada, o Juiz estaria criando uma terceira lei, o que lhe é vedado; a favor da combinação de leis, afirma-se que, se o juiz pode aplicar a lei nova "no todo", poderia também, a benefício do réu, aplicar apenas algum de seus aspectos.

A nosso ver, se os aspectos da lei nova e da lei revogada foram cindíveis, pode o Juiz combiná-las (item 6.2.1).

73. A regra da retroatividade benigna não se aplica às leis excepcionais e temporárias. Estas são sempre ultrativas, projetando seus efeitos para período posterior ao fim de sua vigência (item 6.2.2).

74. No caso das normas penais em branco, quando a norma que complementa o tipo é revogada, a questão deve ser tratada em regra como abolitio criminis. No entanto, se for complementada por norma de caráter excepcional ou temporário, sua revogação não beneficiará o agente (item 6.2.3).

75. Em razão da adoção da teoria da atividade (artigo $4^{\circ}$ do Código Penal), aplicase a lei do tempo da conduta, salvo se lhe sobrevier norma penal mais benéfica. No caso de crime permanente ou continuado, aplica-se a lei vigente ao tempo do último ato de execução, mesmo que mais severa (item 6.2.4). 
76. Em geral, as normas de direito processual penal seguem as regras comuns ao direito intertemporal - ou seja, aplica-se desde logo a lei nova, respeitados o direito adquirido, o ato jurídico perfeito e a coisa julgada. Excepcionalmente, porém, a lei processual penal será ultrativa (nos casos de fiança e prisão preventiva) ou retroativa (nos casos das normas processuais penais de conteúdo material) (item 6.2.5).

\section{b. Direito Intertemporal Tributário}

77. No direito tributário, a lei nova não se volta ao passado (artigo 150, inciso III, alínea $a$, da Constituição Federal), mas se aplica desde logo aos fatos geradores posteriores ao início de sua vigência, ainda que pendentes (artigo 105 do Código Tributário Nacional), a menos que haja instituído ou aumentado tributo - hipótese em que, em regra, só será exigível no exercício financeiro seguinte e depois de noventa dias de sua publicação (artigo 150, inciso III, alíneas $b$ e $c$, da Constituição Federal), salvo exceções constitucionais (artigo $150, \S 1^{\text {o }}$, da Constituição Federal).

Contudo, a lei tributária irá retroagir (artigo 106 do Código Tributário Nacional): (1) no caso de lei expressamente interpretativa e cuja aplicação não importe imposição de penalidade; e (2) quando a lei nova deixe de aplicar ou amenize penalidade, desde que (a) não implique não-pagamento de tributo; e (b) não esteja acobertada por decisão judicial transitada em julgado. Como sempre laboram a benefício do contribuinte, tais hipóteses não se inserem na vedação constitucional à retroatividade da lei tributária, a qual constitui limite ao poder de tributar e deve ser interpretada favoravelmente ao contribuinte (item 6.3). 


\section{REFERÊNCIAS BIBLIOGRÁFICAS}

AMORIM, Sebastião Luiz. Herança jacente e vacante no atual Código Civil. In: DELGADO, Mário Luiz; ALVES, Jones Figueiredo (Coords.). Questões controvertidas no novo Código Civil. São Paulo: Método, 2005. v. 3.

ANTONINI, Mauro. Código Civil comentado: doutrina e jurisprudência. Coord. Cezar Peluso. Barueri: Manole, 2007.

ASCENSÃO, José de Oliveira. Direito civil: teoria geral: relações e situações Jurídicas. Coimbra: Coimbra Ed., 2002.

ASSIS, Araken de. Eficácia da coisa julgada inconstitucional. Revista Dialética de Direito Processual, São Paulo, v. 4, p. 7-28, 2003.

BARBOSA FILHO, Marcelo Fortes. Código Civil comentado: doutrina e jurisprudência. Coord. Cezar Peluso. Barueri: Manole, 2007.

BATALHA, Wilson de Souza Campos. Direito intertemporal. Rio de Janeiro: Forense, 1980.

BDINE JR., Hamid Charaf. Código Civil comentado: doutrina e jurisprudência. Coord. Cezar Peluso. Barueri: Manole, 2007.

BEVILÁQUA, Clovis. Soluções práticas de direito (Pareceres). Rio de Janeiro: Corrêa, Bastos, 1923. v. 1.

Teoria geral do direito civil. Campinas: RED Ed., 2003.

BORGES, Nelson. Direito adquirido, ato jurídico perfeito e coisa julgada: considerações. Curitiba: Juruá, 2005.

CAHALI, Francisco José. Contrato de convivência na união estável. São Paulo: Saraiva, 2002.

CAMPOS, Francisco. Direito civil. Rio de Janeiro: Freitas Bastos, 1956. 
CARDOSO, José Eduardo Martins. A retroatividade e a lei de introdução ao Código Civil. 1992. Dissertação (Mestrado) - Faculdade de Direito, Pontifícia Universidade Católica de São Paulo, São Paulo, 1992.

CARNELUTTI, Francesco. Arte do direito: seis meditações sobre o direito. Traduzido por Ricardo Rodrigues Gama. Campinas: Bookseller, 2001.

CHAVES, Antônio. Lições de direito civil: introdução à ciência do direito e parte geral do Código Civil. 2. ed. São Paulo: Ed. Revista dos Tribunais, 1978.

CHINELLATO, Silmara Juny de Abreu. Direito patrimonial de família. In: DELGADO, Mário Luiz; ALVES, Jones Figueiredo (Coords.). Questões controvertidas no novo Código Civil. São Paulo: Método, 2005.

COELHO, Gil Ernesto Gomes. A multa moratória da convenção de condomínio e o novo Código Civil: questão de direito intertemporal. In: CASCONI, Francisco Antonio; AMORIM, José Roberto Neves (Coords.). Condomínio edilício: aspectos relevantes aplicação do novo Código Civil. São Paulo: Método, 2005.

COSTA, Regina Helena. Código Tributário Nacional comentado: doutrina e jurisprudência, artigo por artigo, inclusive ICMS e ISS. Coordenador Vladimir Passos de Freitas. 4. ed. rev. atual. e ampl. São Paulo: Ed. Revista dos Tribunais, 2007.

CRETElla JÚNIOR, José. Comentários à Constituição Brasileira de 1988. Rio de Janeiro: Forense Universitária, 1991. v. 1.

DELGADO, Mário Luiz. Problemas de direito intertemporal no Código Civil: doutrina \& jurisprudência. São Paulo: Saraiva, 2004.

DELMANTO, Celso; DELMANTO, Roberto; DELMANTO JÚNIOR, Roberto; DELMANTO, Fabio M. de Almeida. Código Penal comentado. 7. ed. rev. atual. e ampl. Rio de Janeiro: Renovar, 2007.

DÍAZ AZNARTE, Maria Teresa. Teoría general de la sucessión de normas en el tiempo: una reflexión crítica sobre los principios ordenadores de la eficacia temporal de las leyes. Valência: Tirant lo Blanch, 2002.

DINAMARCO, Cândido Rangel. Relativizar a coisa julgada material. Revista de Processo, São Paulo, v. 28, n. 109, p. 9-38, jan./mar. 2003. 
DINIZ, Maria Helena. Código Civil anotado. 10. ed. São Paulo: Saraiva, 2004.

. O impacto do Art. 2.035 e Parágrafo Único nos contratos anteriores ao novo CC. In: DELGADO, Mário Luiz; ALVES, Jones Figueiredo (Coords.). Questões controvertidas no novo Código Civil. São Paulo: Método, 2005. v. 4.

. Lei de Introdução ao Código Civil interpretada. 3. ed. São Paulo: Saraiva, 1997.

. Norma constitucional e seus efeitos. 2. ed. atuali. São Paulo: Saraiva. 1992.

DIREITO, Carlos Alberto Menezes. A livre negociação dos índices: leis de ordem pública e teoria da imprevisão. Revista dos Tribunais, São Paulo, v. 80, n. 672, p. 72-79, out. 1991.

DOLINGER, Jacob. A ordem pública internacional em seus diverso patamares. Revista dos Tribunais, São Paulo, v. 93, n. 828, p. 33-42, out. 2004.

DUARTE, Nestor. Código Civil comentado: doutrina e jurisprudência. Coord. Cezar Peluso. Barueri: Manole, 2007.

Direito intertemporal e prescrição no novo Código Civil. In: CIANCI, Mirna (Coord.). Prescrição no novo Código Civil: uma análise interdisciplinar. São Paulo: Saraiva, 2006.

FACHIN, Luiz Edson; RUZYK, Carlos Eduardo Pianovski. Código Civil comentado. Coordenador Álvaro Villaça Azevedo. São Paulo: Atlas, 2003.

FERRAZ JR., Tércio Sampaio. Antinomia. In: FRANÇA, Rubens Limongi (Org.). Enciclopédia Saraiva do Direito. São Paulo: Saraiva, 1977. v. 7.

FERRI, Giovanni B. Ordine pubblico (dir. Priv.) In: ENCICLOPÉDIA del Diritto. Milano: Giuffrè, 1980. v. 30.

FRANÇA, Rubens Limongi. Direito intertemporal brasileiro: doutrina da irretroatividade das leis e do direito adquirido. 2. ed. São Paulo: Ed. Revista dos Tribunais, 1968.

A irretroatividade das leis e o direito adquirido. 3. ed. refun. e atual. do "Direito intertemporal brasileiro". São Paulo: Ed. Revista dos Tribunais, 1982.

Princípios gerais de direito. 2. ed. São Paulo: Ed. Revista dos Tribunais, 1971. 
FRANCISCO, Caramuru Afonso. Lei de Introdução ao Código Civil comentada (DecretoLei n. 4.657, de 4.9.1942). São Paulo: Juarez de Oliveira, 2005.

GABBA, Carlos Francesco. Teoria della retroattività delle leggi. 3. ed. Torino: Torino Unione Tipográfico Editrice, 1891. v. 1, 2, 3, e 4.

GAGLIANO, Pablo Stolze; PAMPLONA FILHO, Rodolfo. Novo curso de direito civil: obrigações. 7. ed. rev., atual. e reform. São Paulo: Saraiva, 2006. v. 2.

GOGLIANO, Daisy. Aquisição. In: FRANÇA, Rubens Limongi (Org.). Enciclopédia Saraiva do Direito. São Paulo: Saraiva, 1977. v. 7.

GONÇALVES, Carlos Roberto. Direito civil brasileiro: direito das coisas. São Paulo: Saraiva, 2006. v. 5.

. Direito civil brasileiro: direito de família. São Paulo: Saraiva, 2005. v. 6.

. Direito civil brasileiro: direito das sucessões. São Paulo: Saraiva, 2007. v. 7.

GONÇALVES, Luiz da Cunha. Princípios de direito civil luso-brasileiro. São Paulo: Max Limonad, 1951. v. 1.

GUIMARÃES, Marilene Silveira. Família e empresa: questões controvertidas. In: DELGADO, Mário Luiz; ALVES, Jones Figueiredo (Coords.). Questões controvertidas no novo Código Civil. São Paulo: Método, 2003.

HART, Herbert L.A. O conceito de direito. 3. ed., com um pós-escrito editado por Penélope A. Bulloch e Joseph Raz, tradução de A. Ribeiro Mendes. Lisboa: Fundação Calouste Gulbenkian, 2001.

HIRONAKA, Giselda Maria Fernandes Novaes. Concorrência do companheiro e do cônjuge na sucessão dos descendentes. In: DELGADO, Mário Luiz; ALVES, Jones Figueiredo (Coords.). Questões controvertidas no novo Código Civil. São Paulo: Método, 2003.

Direito das obrigações. In: DELGADO, Mário Luiz; ALVES, Jones Figueiredo (Coords.). Questões controvertidas no novo Código Civil. São Paulo: Método, 2005.

LACERDA, Belizário Antônio de. Direito adquirido. Belo Horizonte: Del Rey, 1999. 
LACRUZ BERDEJO, José Luis; ASÍS SANCHO REBULLIDA, Francisco de; LUNA SERRANO, Agustín;, DELGADO ECHEVERRÍA, Jesús; RIVERO HERNÁNDEZ, Francisco; RAMS LBESA, Joaquín. Elementos de derecho civil: parte general. 4. ed. rev. e atual. por Jesús Delgado Echeverría. Madrid: Dykinson, 2006.

LEVADA, Cláudio Antônio Soares. O abuso e o novo direito civil brasileiro. 2006. Tese (Doutorado) - Faculdade de Direito, Pontifícia Universidade Católica de São Paulo, São Paulo, 2006. Disponível em: <http://www.sapientia.pucsp.br/tde_busca/arquivo.php?codArquivo=1862>. Publicada em livro homônimo, $O$ abuso e o novo direito civil brasileiro. Jundiaí: Ed. Unianchieta, 2007.

- Fiança locatícia: a responsabilização do garante até entrega das chaves e a faculdade de exoneração do artigo 835 do Código Civil. In: CASCONI, Francisco Antonio; AMORIM, José Roberto Neves (Coords.). Locações: aspectos relevantes - aplicação do novo Código Civil. São Paulo: Método, 2004.

LOTUFO, Renan. Código Civil comentado: obrigações: parte Geral. São Paulo: Saraiva, 2003.

LOUREIRO, Francisco Eduardo. Código Civil comentado: doutrina e jurisprudência. Coord. Cezar Peluso. Barueri: Manole, 2007.

MALUF, Carlos Alberto Dabus. O condomínio edilício no novo Código Civil. Revista do Advogado, São Paulo, v. 22, n. 68, p. 61-69. dez. 2002.

MARTINS, Sérgio Pinto. Direito adquirido e reforma previdenciária. Revista de Previdência Social, São Paulo, ano 23, n. 222, p. 454, 1999.

MARTINS-COSTA, Judith. Os juros (moratórios) legais: para uma interpretação do art. 406 do Código Civil. Migalhas. Disponível em: <http://www.migalhas.com.br/mostra_noticia_articuladas.aspx?cod=1426>. Acesso em: 26 maio 2008.

MASTROIACOVO, Valeria. I limiti alla retroattività nel diritto tributario. Milano: Giuffrè, 2005.

MAXIMILIANO, Carlos. Direito intertemporal ou teoria da retroatividade das leis. 2. ed. Rio de Janeiro: Freitas Bastos, 1955. 
MAZEAUD, Denis. La notion de clause pénale. Paris: Librairie Générale de Droit et de Jurisprudence, 1992.

MEDINA DE LEMUS, Manuel. Derecho civil: parte general. Madrid: Dilex, 2006.

MELlO, Celso Antonio Bandeira de. O direito adquirido e o direito administrativo. Interesse Público, Porto Alegre, v. 8, n. 38, p. 13-24, 2006.

Direito adquirido proporcional. Revista Trimestral de Direito Público, São Paulo, n. 36, p. 18-23, 2001.

MERCOLI, Sylvain. La retroativité dans le droit des contracts. Marseille: Presses Universitaires D'aix-Marseilleis, 2001.

MESSINEO, Francesco. Manuale di diritto civile e commerciale. Milano: Giuffrè, 1957.

MIRABETE, Julio Fabbrini; FABBRINI, Renato N. Manual de direito penal. 24. ed. rev. e atual. São Paulo: Atlas, 2007. v. 1.

MIRANDA, Francisco Cavalcanti Pontes de. Comentários à Constituição de 1946. 2. ed. São Paulo, Max Limonad, 1953. v. 4.

Tratado de direito privado. Rio de Janeiro: Borsoi, 1972. t. 55.

MONTEIRO, Washington de Barros. Curso de direito civil: direito das obrigações. 37. ed. rev. e atual. por Carlos Alberto Dabus Maluf de acordo com o Novo Código Civil (Lei n. 10.406, de 10.1.2002). São Paulo: Saraiva, 2003.

Curso de direito civil: direito das sucessões. 35. ed., rev. e atual. por Ana Cristina de Barros Monteiro França Pinto de acordo com o Novo Código Civil (Lei n. 10.406, de 10.1.2002). São Paulo: Saraiva, 2003.

MOREIRA, Rogério de Meneses Fialho. A nova disciplina dos juros de mora: aspectos polêmicos. In: DELGADO, Mário Luiz; ALVES, Jones Figueiredo (Coords.). Questões controvertidas no novo Código Civil. São Paulo: Método, 2003.

NERY, Rosa Maria de Andrade. Introdução ao pensamento jurídico e à teoria geral do direito privado. São Paulo: Ed. Revista dos Tribunais, 2008. 
NERY JUNIOR, Nelson. Coisa julgada e o Estado democrático de direito. Revista Forense, Rio de Janeiro, v. 100, n. 375, p. 141-159, set./out. 2004.

; NERY, Rosa Maria de Andrade. Novo Código Civil e Legislação Extravagante anotados. 1. ed. São Paulo: Ed. Revista dos Tribunais, 2002.

NORONHA, Edgard Magalhães. Direito penal. 28. ed. atual. por Adalberto José Q. T. de Camargo Aranha. São Paulo: Saraiva, 1991. v. 1.

NORONHA, Fernando. Indispensável reequacionamento das questões fundamentais de direito intertemporal. Revista dos Tribunais, São Paulo, v. 94, n. 837, p. 55-78, jul. 2005.

Retroatividade, eficácia imediata e pós-atividade das leis: sua caracterização correta, como indispensável para solução dos problemas de direito intertemporal. Cadernos de Direito Constitucional e Ciência Política, São Paulo, v. 6, n. 23, p. 91-110, abr./jun. 1998.

OLIVEIRA, Euclides de. Alteração do regime de bens no casamento. In: DELGADO, Mário Luiz; ALVES, Jones Figueiredo (Coords.). Questões controvertidas no novo Código Civil. São Paulo: Método, 2003.

União estável: do concubinato ao casamento, antes e depois do novo Código Civil. 6. ed. São Paulo: Método, 2003.

OST, François. O tempo do direito. Tradução de Maria Fernanda Oliveira. Lisboa: Instituto Piaget, 1999.

PACIFICI-MAZZONI, Emidio. Istituzioni di diritto civile italiano. 5. ed. Torino: Unione Tipografico-Editrice Torinese, 1929. v. 1.

PEREIRA, Caio Mário da Silva. Instituições de direito civil. 12. ed. Rio de Janeiro: Forense, 1991. v. 1.

PIRES, Mara Coeli Simões. Direito adquirido e ordem pública: segurança jurídica e transformação democrática. Belo Horizonte: Del Rey. 2005.

PORCHAT, Reynaldo. Da retroactividade das leis civis. São Paulo: Duprat \& Comp., 1909. 
RAMOS, Elival da Silva. A proteção aos direitos adquiridos no direito constitucional brasileiro. São Paulo: Saraiva, 2003.

RÁO, Vicente. Ato jurídico. São Paulo: Max Limonad, 1961.

O direito e a vida dos direitos. 6. ed. anotada e atualizada com o novo Código Civil por Ovídio Rocha Barros Sandoval. São Paulo: Ed. Revista dos Tribunais, 2005.

REALE, Miguel. Estudos preliminares do Código Civil. São Paulo: Ed. Revista dos Tribunais, 2003.

. História do novo Código Civil. São Paulo: Ed. Revista dos Tribunais, 2005.

RIZZARDO, Arnaldo. Contratos. 3. ed. Rio de Janeiro: Forense, 2004.

ROCHA, Manoel Antônio Coelho da. Instituições de direito civil. Ed. cuidada por Alcides Tomasetti Jr. São Paulo: Saraiva, 1984. t. 2.

RODRIGUES, Silvio. Direito civil: direito das coisas. 27. ed. atual. de acordo com novo Código Civil (Lei n. 10.406, de 10-1-2002). São Paulo: Saraiva, 2002. v. 5.

Direito civil: direito de família. 27. ed. atual. por Francisco José Cahali; com anotações sobre o novo Código Civil (Lei n. 10.406, de 10-1-2002). São Paulo: Saraiva, 2002. v. 6.

Direito civil: direito das sucessões. 25. ed. atual. por Zeno Veloso; de acordo com o novo Código Civil (Lei n. 10.406, de 10-1-2002). São Paulo: Saraiva, 2002.

Direito civil: parte geral. 32. ed. atual. de acordo com novo Código Civil (Lei n. 10.406, de 10-1-2002). São Paulo: Saraiva, 2002. v. 1.

ROSENVALD, Nelson. Código Civil comentado: doutrina e jurisprudência. Coord. Cezar Peluso. Barueri: Manole, 2007.

ROUBIER, Paul. Les conflits de lois dans le temps (théorie dite de la non-rétroactivité des lois). Paris: Librairie du Recuiel Sirey, 1929.

SANTOS, Antonio Jeová. Direito intertemporal e o novo Código Civil: aplicações da Lei 10.406/2002. 2. ed. rev. atual. e ampl. São Paulo: Ed. Revista dos Tribunais, 2004. 
SANTOS, J. M. de Carvalho. Código Civil brasileiro interpretado: introdução e parte geral. Rio de Janeiro: Freitas Bastos, 1943. v. 1.

SANTOS, Simone Orodeschi Ivanov dos. Regime patrimonial na união estável e direito intertemporal. 2004. Dissertação (Mestrado) - Faculdade de Direito, Pontifícia Universidade Católica de São Paulo, São Paulo, 2004.

SIDOU, J. M. Othon. A "existência" da lei (regras de direito intertemporal). In: MARTINS, Ives Gandra da Silva (Coord.). As vertentes do direito constitucional contemporâneo. Rio de Janeiro: América Jurídica, 2002.

SILVA, De Plácido e. Vocabulário jurídico. 27. ed. rev. e atual. por Nagib Slaibi Filho e Gláucia Carvalho. Rio de Janeiro: Forense, 2008.

SILVA, José Afonso da. Curso de direito constitucional positivo. 15. ed. rev. atual. nos termos da Reforma Constitucional. São Paulo: Malheiros Ed., 1988.

SILVA, Luiz Antonio Rodrigues. Pequena reflexão a respeito da multa de até $2 \%$ sobre a contribuição condominial em atraso. In: CASCONI, Francisco Antonio; AMORIM, José Roberto Neves (Coords.). Condomínio edilício: aspectos relevantes - aplicação do novo Código Civil. São Paulo: Método, 2005.

SIMÃO, José Fernando. Aspectos controvertidos da prescrição e decadência na teoria geral dos contratos e contratos em espécie. In: DELGADO, Mário Luiz; ALVES, Jones Figueiredo (Coords.). Questões controvertidas no novo Código Civil. São Paulo: Método, 2005. v. 4.

STOCO, Rui. Tratado de responsabilidade civil. 6. ed. rev. atual. e ampl. São Paulo: Ed. Revista dos Tribunais, 2004.

TARCHI, Rolando. Le leggi di sanatoria nella teoria del diritto intertemporale. Milano: Giuffrè, 1990.

TARTUCE, Flávio. Função social dos contratos: do Código de Defesa do Consumidor ao Código Civil de 2002. São Paulo: Método, 2007. (Coleção Prof. Rubens Limongi França, v. 4).

TELLES JUNIOR, Goffredo da Silva. Iniciação na ciência do direito. 3. ed. São Paulo: Saraiva, 2006. 
TERAOKA, Thiago Massao Cortizo. Poder Constituinte e direitos adquiridos. 2006. Dissertação (Mestrado) - Faculdade de Direito, Universidade de São Paulo, São Paulo, 1992.

THEODORO JÚNIOR, Humberto; FARIA, Juliana Cordeiro de. A coisa julgada institucional e os instrumentos processuais para seu controle. Revista dos Tribunais, São Paulo, v. 91, n. 795, p. 19-40, jan. 2002.

TOLEDO, Cláudia. Direito adquirido e Estado democrático de direito. São Paulo: Landy, 2003.

TOLOMEI, Carlos Young. A proteção do direito adquirido sob o prisma civilconstitucional: uma perspectiva sistemático-axiológica. Rio de Janeiro: Renovar, 2005.

TOMASETTI JÚNIOR, Alcides. Aspectos da proteção contratual do consumidor no mercado imobiliário urbano. Rejeição das clausulas abusivas pelo direito comum. Revista de Direito do Consumidor, São Paulo, n. 2, p. 52-66, mar. 1992.

VELOSO, Zeno. Direito real de habitação na união estável. In: DELGADO, Mário Luiz; ALVES, Jones Figueiredo (Coords.). Questões controvertidas no novo Código Civil. São Paulo: Método, 2003.

VENOSA, Sílvio de Salvo. Direito civil: parte geral. 2. ed. São Paulo: Atlas, 2002. v. 1.

Direito civil: teoria geral das obrigações e teoria dos contratos. 2. ed. São Paulo: Atlas, 2002. v. 2.

VERDERA IZQUIERDO, Beatriz. La irretroactividad: problemática general. Madrid: Dykinson, 2006.

VILLEY, Michel. Filosofia do direito: definições e fins do direito: os meios do direito. Traduzido por Márcia Valéria Martinez de Aguiar, revisão técnica de Ari Sólon. São Paulo: Martins Fontes, 2003.

WAMBIER, Teresa Arruda Alvim; MEDINA, José Miguel Garcia. O dogma da coisa julgada: hipóteses de relativização. São Paulo: Ed. Revista dos Tribunais, 2003.

WEYNE, Gastão Rúbio de Sá. Direitos adquiridos: um reexame necessário. São Paulo: Memória Jurídica, 2005. 


\section{REFERÊNCIAS JURISPRUDENCIAIS}

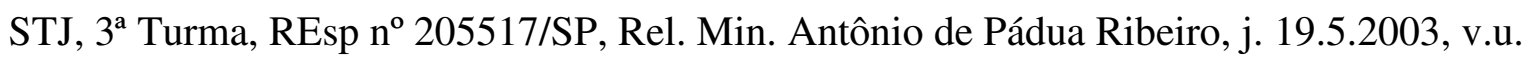

STJ, $4^{\mathrm{a}}$ Turma, REsp n 45.666/SP, Rel. Min. Barros Monteiro, j. 17.5.1994, votação por maioria.

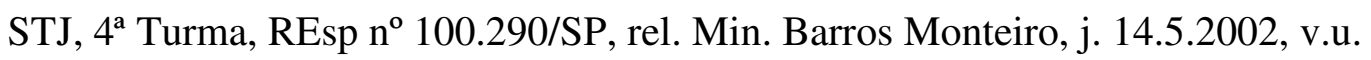

STJ, $3^{\text {a }}$ Turma, REsp no 594.486/MG, Rel. Min. Castro Filho, j. 13.6.2005, v.u.

STF, $1^{\text {a }}$ Turma, Ag. Reg. em Ag. Inst. $n^{\circ}$ 135.632-4/RS, Rel. Min. Celso de Mello, j. 10.10.1995, v.u.

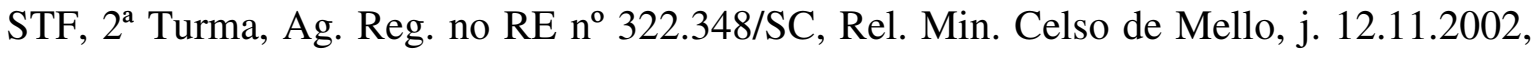
v.u.

STF, $2^{\text {a }}$ Turma, HC no 95435/RS, Rel. Min. Cezar Peluso, j. 21.10.2008, votação por maioria.

STJ, $1^{\text {a }}$ Turma, REsp no 805806/RJ, Rel. Min. Denise Arruda, j. 13.11.2007, v.u.

STJ, $3^{\text {a }}$ Turma, REsp nº 5723/MG, Rel. Min. Eduardo Ribeiro, j. 25.6.1991, v.u.

TJ/SP, 6a Câm. Dir. Priv., AI no 5301974200, j. 29.11.2007, Rel. Des. Encinas Manfré, votação por maioria.

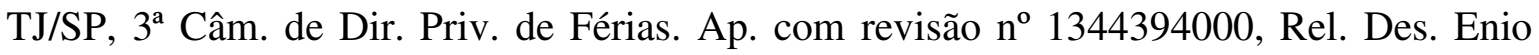
Zuliani, j. 3.3.2003, v.u.

STF, $1^{\text {a }}$ Turma, Ag. Reg. no Ag. Inst. no 511024/PR, Rel. Min. Eros Grau, j. 14.6.2005, v.u. 
STJ, $1^{\text {a }}$ Turma, REsp n ${ }^{\text {1 }}$ 1000838/RS, Rel. Min. Francisco Falcão, j. 21.2.2008, v.u.

STJ, $2^{\text {a }}$ Turma, REsp no 215881/PR, Rel. Franciulli Netto, j. 13.6.2000, votação por maioria.

TJ/SP, 11ª Câm. Dir. Priv., Ap. c/ rev. nº 7.220.054-5, Rel. Des. Gilberto Pinto dos Santos, vu.

STJ, 6a Turma, REsp n ${ }^{\circ}$ 94.850/SP, Rel. Min. Hamilton Carvalhido, j. 18.12.2002, v.u.

STJ, $3^{\text {a }}$ Turma, Ag. Reg. no REsp n ${ }^{\circ}$ 727842/SP, Rel. Min. Humberto Gomes de Barros, j. 14.12.2007, v.u.

STF, Pleno, RE n 141.190-2/SP, Rel. Min. Ilmar Galvão, j. 14.9.2005, votação por maioria.

STJ, Corte Especial, REsp $\mathrm{n}^{\mathrm{o}}$ 274.732/SP, Rel. Min. José Arnaldo da Fonseca, j. 25.3.2004, votação por maioria.

TJ/RS, $8^{\text {a }}$ Câm. Cív., Ap. Cív. no 70010050441, Re. Des. José Ataídes Siqueira Trindade, j. 31.3.2005, v.u.

TJ/SP, 9a Câm. Dir. Priv., Ap. Cív. no 489.117-4/6-00, Rel. Des. José Luiz Gavião de Almeida,

j. 2.10.2007, votação por maioria.

TJ/SP, Órgão Especial, ADin Estadual no 148.484-0/8-00, Rel. Des. José Luís Palma Bisson, j. 2.4.2008, votação por maioria.

TJ/RS, $7^{\text {a }}$ Câm. Cív., Ap. Cív. no 599387677, Rel. Des. Luiz Felipe Brasil Santos, j. 06/10/1999, v.u.

STJ, $1^{\text {a }}$ Turma, REsp no 394.671/PR, Rel. Min. Luiz Fux, j. 19.11.2002, v.u.

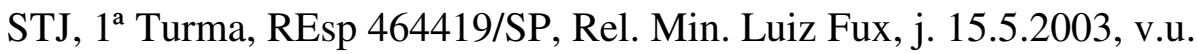


STF, Pleno, RE nº 134.570/RS, Rel. Min. Marco Aurélio, j. 15.3.2006, v.u.

TJ/RS, 7ª Câm. Cív., Ap. Cív. no 70011082997, Rel. Des. Maria Berenice Dias, j. 1.6.2005, v.u STF, Pleno, ADIN no 492-0/DF, Rel. Min. Moreira Alves, j. 25.6.1992, votação por maioria.

STJ, $3^{\text {a }}$ Turma, REsp no 809.329/RJ, Rel. Min. Nancy Andrighi, j. 25.3.2008, votação por maioria.

STJ, $3^{\text {a }}$ Turma, REsp 821807/PR, Rel. Min. Nancy Andrighi, j. 19.10.2006, v.u.

STF, Pleno, MS nº 21.216-1/DF, Rel. Min. Octavio Gallotti, j. 5.12.1990, votação por maioria.

STF, $2^{\text {a }}$ Turma, RMS nº 21774/DF, Rel. Min. Paulo Brossard, j. 4.10.1994, v.u.

TJ/SP, $11^{\text {a }}$ Câm. Dir. Priv., AI nº 7.211.866-6, Rel. Des. Paulo Dias de Moura Ribeiro, j. 2.4.2008, v.u.

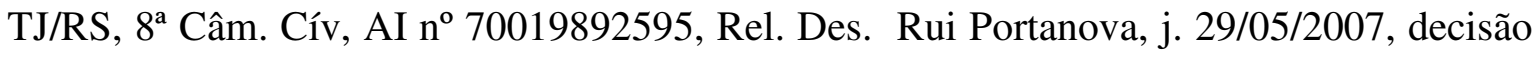
monocrática.

STJ, $4^{\mathrm{a}}$ Turma, REsp 61885/SP, Rel. Min. Ruy Rosado de Aguiar, j, 12.9.2005, v.u.

STJ, 4ª Turma, REsp no 65.691/SP, Rel. Min. Sálvio de Figueiredo Teixeira, j. 24.3.1997, v.u.

STJ, $1^{\text {a }}$ Turma, REsp no 1044550/PE, Rel. Min. Teori Albino Zavascki, j. 27.5.2008, v.u.

STJ, $1^{\text {a }}$ Turma, REsp n 9 932.329/RJ, Rel. Min. Teori Albino Zavascki, j. 15.5.2007, v.u. 